\author{
UNIVERSIDADE DE SÃO PAULO \\ INSTITUTO DE PSICOLOGIA \\ CURSO DE PÓS-GRADUAÇÃO EM PSICOLOGIA \\ ÁREA DE CONCENTRAÇÃO PSICOLOGIA EXPERIMENTAL
}

\title{
A EDUCAÇÃO AMBIENTAL ATRAVÉS DO CONTATO DIRIGIDO COM A NATUREZA
}

Zysman Neiman

São Paulo, 2007 


\author{
UNIVERSIDADE DE SÃO PAULO \\ INSTITUTO DE PSICOLOGIA \\ CURSO DE PÓS-GRADUAÇÃO EM PSICOLOGIA \\ ÁREA DE CONCENTRAÇÃO PSICOLOGIA EXPERIMENTAL
}

\title{
A EDUCAÇÃO AMBIENTAL ATRAVÉS DO CONTATO DIRIGIDO COM A NATUREZA
}

Tese apresentada à Universidade de São Paulo como parte dos requisitos para obtenção do título de Doutor em Psicologia.

Orientador: Prof. Dr. César Ades

Zysman Neiman

São Paulo, 2007 
Neiman, Zysman

A Educação Ambiental através do contato dirigido com a natureza / Zysman Neiman - São Paulo: USP / Curso de Pós-Graduação em Psicologia/ Área de Concentração: Psicologia Experimental, 2007.

$x i, 138$ f., 5 Anexos.

Orientador: César Ades

Tese (doutorado) - USP / Curso de Pós-Graduação em Psicologia/ Área de Concentração: Psicologia Experimental, 2007.

Referências bibliográficas: f. 118-138.

1. Ecoturismo. 2. Educação Ambiental. 3. Psicologia Ambiental - Tese. I. Ades, César. II.Universidade de São Paulo, Curso de Pós-Graduação em Psicologia/ Área de Concentração: Psicologia Experimental. III. Título.

Impresso em papel 100\% reciclado - frente e verso

Tamanho A4 $(210 \times 297 \mathrm{~mm})$

$75 \mathrm{~g} / \mathrm{m}^{2}$

$\mathrm{ECO}^{\circledR}$

CHAMEX 


\section{A EDUCAÇÃO AMBIENTAL ATRAVÉS DO CONTATO DIRIGIDO COM A NATUREZA}

Banca Examinadora:

Data da Aprovação: / /2007

São Paulo, 2007 


\section{Agradecimentos}

Ao Prof. Dr. César Ades, minha referência de pesquisador, pela insistência com que me manteve no caminho mais coerente para o trabalho, e pelos preciosos conselhos;

À Andréa Rabinovici, companheira de todas as idéias, de todos os momentos, mesmo quando tudo parecia dar errado, pelo amor e pelo exemplo de dedicação a tudo que faz;

À Lilith, ao Lucas e à Cora, filhos queridos que são minha razão para tudo e a quem fiquei devendo tantas horas de convívio por conta deste trabalho;

Aos meus pais, Benedito e Dirce, pelo exemplo, pelo amor, por tudo que permitiu a proeza de transformar o aluno pobre da periferia em "doutor";

Ao herói da natureza Sr. Antônio Malheiros, o maior ambientalista que conheci e que me inspirou nos caminhos da luta pela preservação;

À Ana Paula Lolato Secco, amiga tão especial que muito contribuiu com a coleta de dados desta pesquisa e a quem devo muitos momentos de alegria no trabalho conjunto na natureza e no dia-a-dia de convívio;

À Alberto Picon dos Santos Gancho, Alexandre Garcia Gonçalves Ferreira, José Artur Barroso Fernandes, Sérgio da Silva Prado Kopersztych, Marcelo Faria de Oliveira, Maria Emerenciana Raia, Marylin Del Nero Grecco, Maria Índia Bonduki, Marina de Lima Minari, Patrícia Machado da Costa, Rubens Hashinoto, André Scharlachi Cabral, Eliana Britto Garcia e Rodrigo Stephan de Souza Telles, todos da equipe de amigos e companheiros do Instituto Physis - Cultura \& Ambiente, que por acreditarem numa idéia e lutarem por ela, tornaram possível esta jornada. Vocês são co-autores deste trabalho; 
Aos Professores Doutores Fernando Leite Ribeiro e Eda Terezinha de Oliveira Tassara, pelas opiniões e sugestões preciosas que muito me foram úteis durante o processo de qualificação;

À Malila Prado, à Maria Índia Bonduki e à Cláudia Astorino pela amizade e pelo auxílio no "Abstract" e no " "Resumen";

À Eliana Cardoso Leite, Nadja Castilho da Costa, e Alexandre de Gusmão Pedrini pela leitura atenciosa das versões preliminares e pelas sugestões de melhorias;

Ao Instituto Florestal e equipe do PETAR, por terem tornado possível o trabalho de campo ao longo dos últimos 16 anos;

Aos Professores Doutores Wilson Abrahão Rabahy e Luiz Renato Ignarra, da FIPE-USP, pelo apoio durante a coleta de alguns dados deste trabalho;

À Educadora Ambiental Renata F. Allegro, cujo exemplo me fez enxergar de forma muito nítida a força das emoções na conversão à causa ambiental;

Às educadoras e colegas Ana Paula Stevanelli Ramos, Milena Sgarzi, Lucijaine Rezende, Sandra Gonçalves Sousa, Geovânia Borges, Maristela Abreu Simone Camargo, pela amizade, pelo afeto e pelo apoio durante a realização deste trabalho;

À Solange Terezinha de Lima Guimarães, Marcelo Teixeira César de Oliveira, Simone Mamede, Maristela Benites, Rita Mendonça, Anamaria Stranz, Mônica Pilz Borba, Célia Serrano, Lúcia Helena Manzochi, Gabriela Príoli, Gemina Born, Suzana Padua e Viviane Junqueira, por compartilharem comigo as encantadoras estradas da Educação Ambiental no Brasil.

Aos meus alunos e participantes das viagens, sem os quais não teria sido possível entender o quanto precisamos da natureza;

À todos os amigos "abandonados" por um doutorando super ocupado, para os quais pretendo continuar recorrendo sempre que sentir o quanto precisamos das pessoas queridas ao nosso redor;

Àqueles que, por esquecimento imperdoável, não foram aqui citados nominalmente, mas me ajudaram em algum momento e confiaram que este trabalho seria possível. 


\section{Resumo}

Esta tese apresenta os resultados de um estudo sobre o surgimento de atitudes próambiente, num quadro de inter-relação entre Educação Ambiental e Ecoturismo. Mostra-se aqui que o contato com a natureza é efetivo em gerar atitudes e motivações ambientalistas. A experiência obtida em 16 anos e 107 viagens de Ecoturismo ao Parque Estadual Turístico do Alto Ribeira - PETAR, com grupos de participantes de atividades dirigidas serviu de ponto de partida para a presente pesquisa. Em estudos iniciais, foram feitas entrevistas com visitantes de 10 áreas naturais do Brasil, visando avaliar suas principais motivações para as visitas a essas localidades e foram aplicados questionários a diversos profissionais de Educação Ambiental a respeito de suas motivações pessoais e estratégias mais eficientes para mudanças de atitudes ambientalistas. A principal motivação apontada pelos visitantes foi de ordem afetiva ("contemplação ou contado com a natureza", "repouso ou fuga da rotina"). Apesar de ser muito marcante na sua vida, os profissionais de Educação Ambiental atribuíram uma importância relativamente menor ao contato com a natureza. Num estudo experimental, em duas replicações, foram comparados grupos que tiveram um contato dirigido com a natureza (em viagem ao PETAR) a outros que serviram de controle, verificando-se possíveis mudanças de conhecimentos, sentimentos, valores, atitudes e vieses paradigmáticos. A visita dirigida gerou mudanças significativas no sentido de uma transformação dos conhecimentos, valores e atitudes em direção a um comportamento pró-ambiente. As viagens dirigidas à natureza, entretanto, não foram suficientes para gerar percepções diferentes em relação aos paradigmas de Desenvolvimento Sustentável e de Sociedades Sustentáveis. Concluise que a concepção do Ecoturismo como um "turismo de destino" (a natureza) deve ser substituída por uma "forma de fazer turismo", na qual o papel do profissional condutor não se resume a "levar", mas sim a "fazer perceber". Ao promover afetos especiais no contato com a natureza, o Ecoturismo pode gerar mudanças motivacionais significativas para a constituição de atitudes e valores pró-ambiente.

Palavras-Chave: Ecoturismo, Educação Ambiental, Atitudes Pró-Ambiente 


\section{Abstract}

Neiman, Zysman. The Environmental Education through Contact Directed with the Nature. São Paulo, 2007. 138p. Thesis (Instituto de Psicologia - Universidade de São Paulo).

Neiman, Zysman. The Environmental Education through Contact Directed with the Nature. São Paulo, 2007. 199p. Thesis (Instituto de Psicologia - Universidade de São Paulo).

This thesis presents the results of a study on the rising of pro-environmental attitudes, in an interrelation between Environmental Education and Ecotourism. In this paper, it's shown that the contact with nature is effective in generating environmentalist attitudes and motivations. The experience acquired in 16 years and 107 ecotourist trips to Parque Estadual Turístico do Alto Ribeira - PETAR (Alto Ribeira Turistic State Park) with groups of participants in directed activities was the starting point for the current research. In initial studies, interviews were conducted with visitors of 10 natural areas in Brazil, focusing on the assessment of their main reasons to visit those places, and surveys were carried out with several Environmental Education professionals aiming at their personal reasons and more efficient strategies for changes in the attitude towards the environment. The main reason pointed out by the visitors was of emotional nature (contemplation or contact with nature, relaxation or an escape from routine). Although the contact with nature is outstanding in Environmental Education professionals' lives, they gave a relatively smaller importance to it. In an experimental study, in two applications, two groups were compared: one which had a directed contact with nature (in trips to PETAR) and a control group, verifying possible changes of knowledge, feelings, values, attitudes and paradigms. The directed visit generated many meaningful changes in what regards knowledge, value and attitude towards a pro-environmental behavior change. The directed trips to the nature, however, were not enough to create different perceptions of Sustainable Development and Sustainable Societies paradigms. The conclusion reached is that the conception of Ecotourism as "destination tourism" (to nature) must be substituted by a "way of making tourism", in which the role of the leading professional is not only "guiding", but "making the traveler understand". When boosting special emotions out of the contact with nature, Ecotourism can generate meaningful motivational changes for the construction of proenvironmental attitudes and values.

Keywords: Ecotourism, Environmental Education, Pro-Environmental Attitudes 


\section{Resumen}

Neiman, Zysman. la Educación Ambiental atraves del contacto dirigió con la naturaleza. São Paulo, 2007. 199p. Tesis (Instituto de Psicologia-Universidade de São Paulo).

Esta tesis presenta los resultados de un estudio sobre el surgimiento de actitudes proambiente, en una interrelación entre Educación Ambiental y Ecoturismo. Se muestra aquí que el contacto con la naturaleza es eficaz en la generación de actitudes y de motivaciones ambientalistas. La experiencia adquirida en 16 años y 107 viajes de ecoturismo al Parque Estadual Turístico do Alto Ribeira - PETAR, con grupos de participantes en actividades dirigidas han sido el punto de partida para esta investigación. En estudios iniciales, han sido hechas entrevistas con los visitantes de 10 áreas naturales en Brasil, con el objetivo de evaluar sus principales motivaciones para las visitas a esos lugares, y han sido realizadas encuestas a varios profesionales de Educación Ambiental sobre sus motivaciones personales y estrategias más eficientes para el cambio de actitudes ambientales. La razón principal señalada por los visitantes era emocional ("contemplación o contacto con la naturaleza" "reposo o un escape de la rutina"). Aunque el contacto con la naturaleza es muy importante en sus vidas, los profesionales de Educación Ambiental ambientales señalaron una importancia relativamente menor para el contacto con la naturaleza. En un estudio experimental, en dos momentos, se compararon grupos que han tenido un contacto dirigido con la naturaleza (en viaje al PETAR) a otros - los llamados grupos de control, verificándose posibles cambios de conocimiento, sensaciones, valores, actitudes y paradigmas. La visita dirigida generó muchos cambios significativos en la transformación del conocimiento, de los valores y de las actitudes hacia el comportamiento pro-ambiental. Los viajes dirigidos a la naturaleza, sin embargo, no han sido suficientes para generar percepciones distintas en relación al Desarrollo Sostenible y de Sociedades Sostenibles. Se concluye que la concepción de Ecoturismo como un "turismo de destinación" (la naturaleza) debe ser sustituido por una "manera de hacer turismo", en el cual el papel del conductor no es sólo "llevar", sino "hacer percibir". Al promover afectos especiales en el contacto con la naturaleza, el Ecotourismo puede generar cambios motivacionales significativos para la construcción de actitudes y valores pro-ambientales.

Palabras-Llave: Ecoturismo, Educación Ambiental, Actitudes Pro-Ambientales 


\section{Índice de Figura e de Tabelas}

\begin{tabular}{|c|c|}
\hline 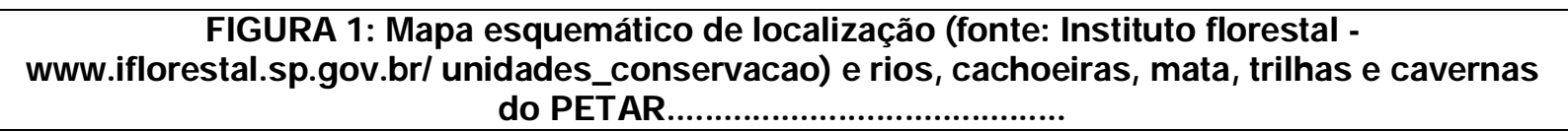 & 42 \\
\hline $\begin{array}{c}\text { FIGURA 2: Grupo iniciando visitação no Parque Estadual Turístico do Alto Ribeira - } \\
\text { PETAR } . . . . \ldots \ldots \ldots \ldots \ldots . . . . . . . . .\end{array}$ & 43 \\
\hline $\begin{array}{l}\text { FIGURA 3: Diversas atividades realizadas com os participantes de viagens ao Parque Estadual } \\
\text { Turístico do Alto Ribeira - PETAR (Fotos: Zysman Neiman/jun- } \\
\text { 2006) }\end{array}$ & 50 \\
\hline $\begin{array}{l}\text { FIGURA 4: Parque Est. do J acupiranga e visitantes nas passarelas iluminadas da Caverna do } \\
\text { Diabo....... }\end{array}$ & 55 \\
\hline 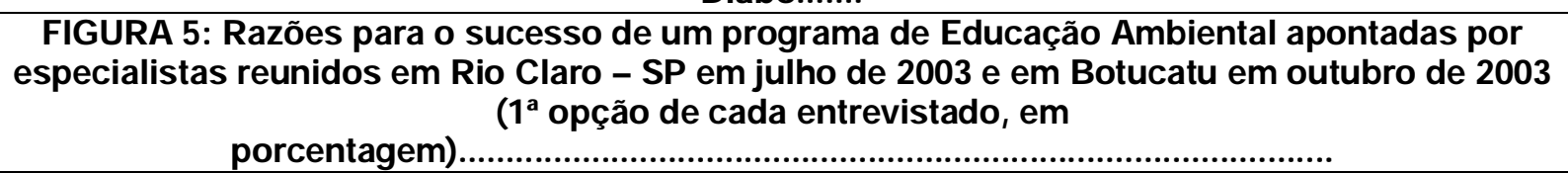 & 69 \\
\hline $\begin{array}{l}\text { FIGURA 6: Motivos de interesse pessoal pela Educação Ambiental apontados por } \\
\text { especialistas reunidos em Rio Claro - SP em julho de } 2003 \text { e em Botucatu em outubro de } 2003 \\
\text { (1’â opção de cada entrevistado, em }\end{array}$ & 70 \\
\hline $\begin{array}{l}\text { FIGURA 7: 2a opção apontada por especialistas reunidos em Rio Claro - SP em julho de } 2003 \text { e } \\
\text { em Botucatu em outubro de } 2003 \text { que alegaram “atividade profissional” como 1a opção (em } \\
\text { porcentagem)..... }\end{array}$ & 71 \\
\hline 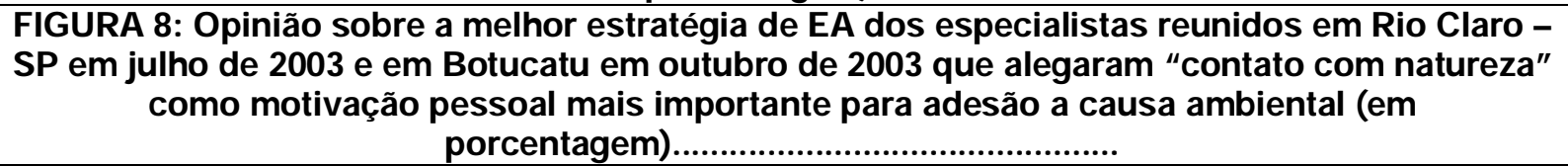 & 72 \\
\hline FIGURA 9: Arranjo & 75 \\
\hline FIGURA 10: Fluxograma dos estudos & 99 \\
\hline
\end{tabular}

\begin{tabular}{|c|c|}
\hline 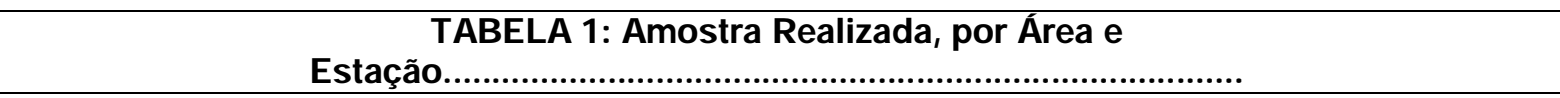 & 63 \\
\hline TABELA 2: Motivos da Visita às Unidades de Conservação em Geral................... & 64 \\
\hline 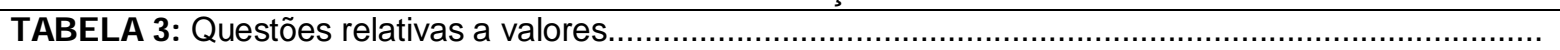 & 78 \\
\hline 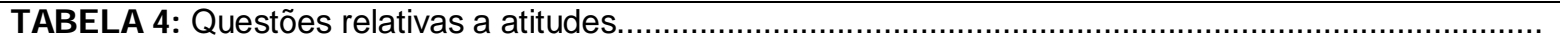 & 78 \\
\hline $\begin{array}{l}\text { TABELA 5a: Teste de Mann-Whitney para comparação da auto-avaliação de conhecimentos sobre } \\
\text { conceitos de TP X TT }\end{array}$ & 80 \\
\hline 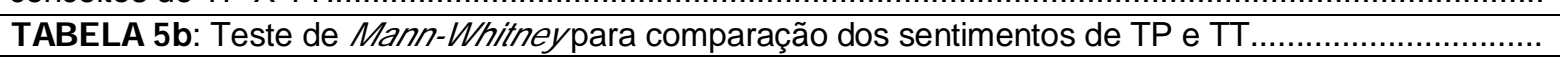 & 80 \\
\hline 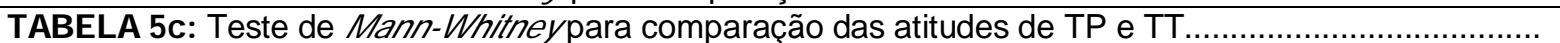 & 81 \\
\hline 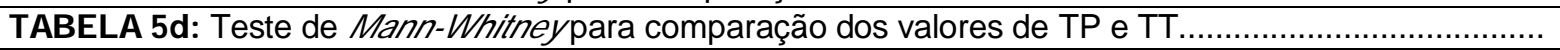 & 81 \\
\hline 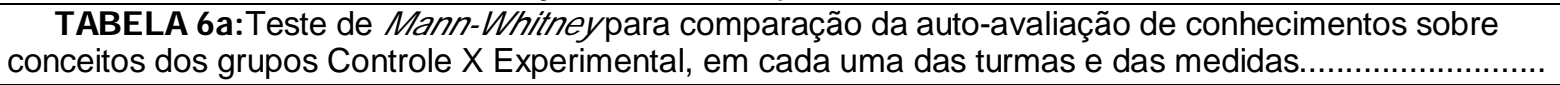 & 82 \\
\hline 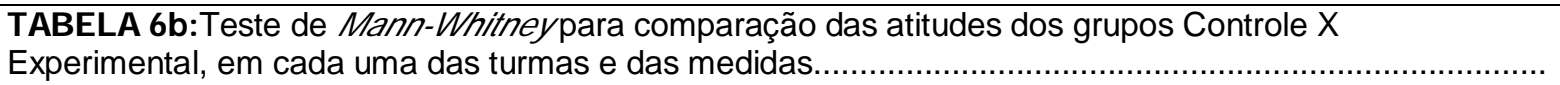 & 82 \\
\hline 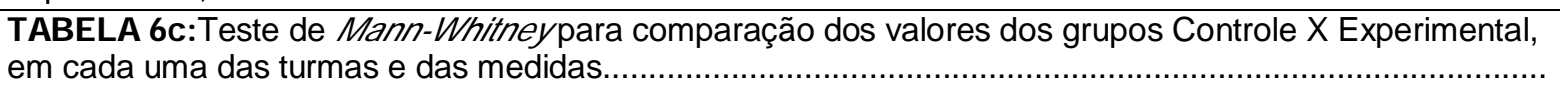 & 83 \\
\hline 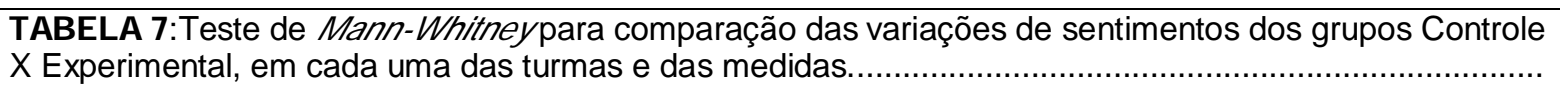 & 83 \\
\hline $\begin{array}{l}\text { TABELA 8: Diferenças estatísticas referentes à “auto-avaliação de conhecimentos" nos Pré e Pós- } \\
\text { Testes. }\end{array}$ & 84 \\
\hline TABELA 9: Diferenças estatísticas referentes a "sentimentos" nos Pré e Pós-Testes......... & 85 \\
\hline
\end{tabular}




\begin{tabular}{|c|c|}
\hline 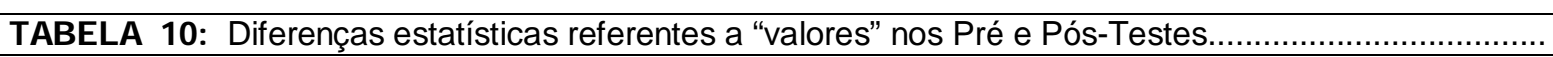 & 86 \\
\hline 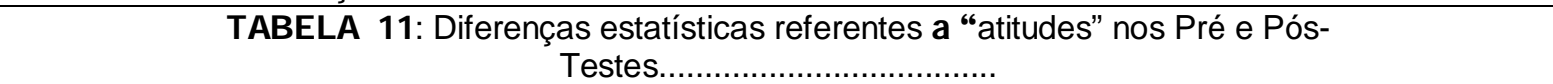 & 87 \\
\hline 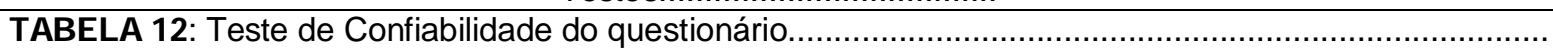 & 88 \\
\hline $\begin{array}{l}\text { TABELA 13: Teste de Confiabilidade das partes do } \\
\text { questionário }\end{array}$ & 88 \\
\hline TABELA 14: Estatísticas Descritivas. & 88 \\
\hline TABELA 15: Estatística para o total dos itens & 89 \\
\hline 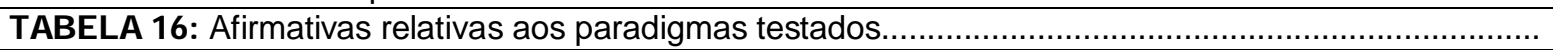 & 94 \\
\hline $\begin{array}{l}\text { TABELA 17: Teste de Mann-Whitney para comparação das turmas Pedagogia (TP) e Turismo (TT), em } \\
\text { cada uma das medidas.......... }\end{array}$ & 95 \\
\hline 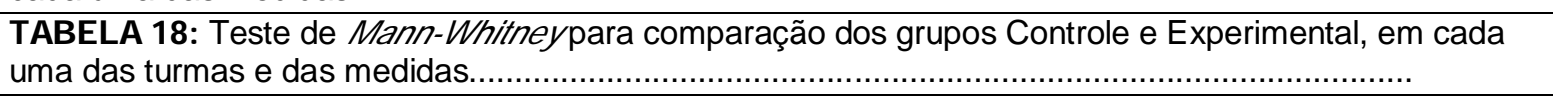 & 96 \\
\hline 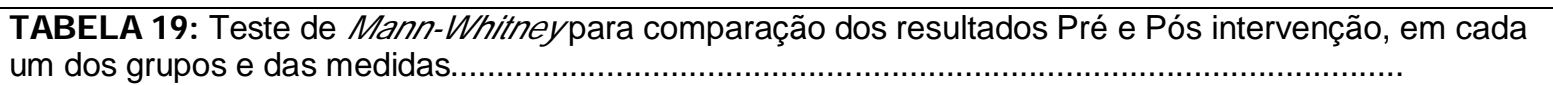 & 97 \\
\hline TABELA 20: Diferenças estatísticas referentes às afirmações nos Pré e Pós-Teste & 98 \\
\hline
\end{tabular}




\section{Lista de Siglas e Abreviações}

EA - Educação Ambiental

Embratur - Instituto Brasileiro de Turismo

FIPE - Fundação Instituto de Pesquisas Econômicas da USP

Ibama - Instituto Brasileiro do Meio Ambiente e dos Recursos Naturais

Renováveis

ONG - Organização Não Governamental

PETAR - Parque Estadual Turístico do Alto Ribeira

PNUMA - Programa das Nações Unidas para o Meio Ambiente.

SBE - Sociedade Brasileira de Espeleologia

USP - Universidade de São Paulo 


\section{Sumário}

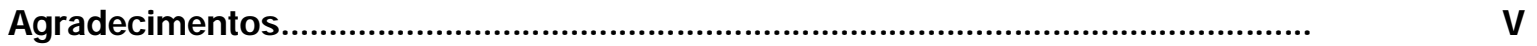

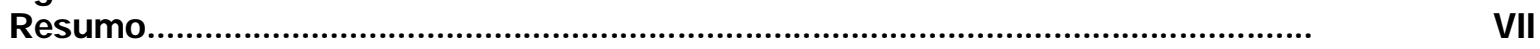

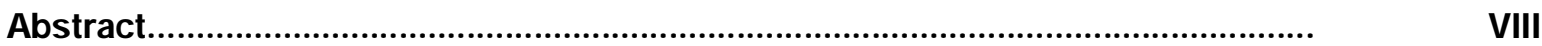

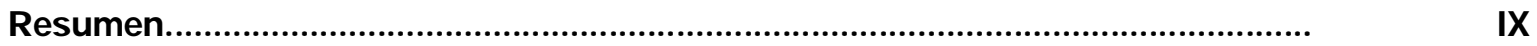

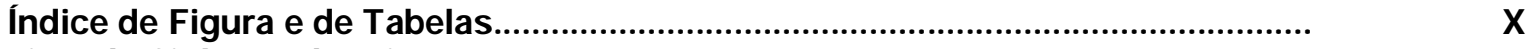

Lista de Siglas e Abreviações................................................................................ XI

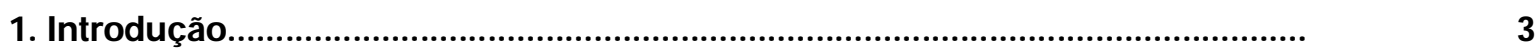

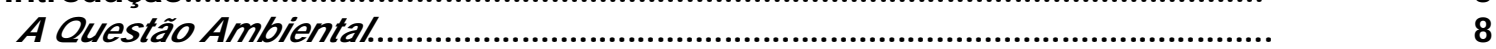

Educação Ambiental: um campo em construção.................................... 14

E ducação Ambiental para o Desenvolvimento Sustentável ou Educação

Ambiental para as Sociedades Sustentáveis?

20

A importância das Pesquisas em Educação Ambiental, Percepção,

Representações e Psicologia Ambiental................................................. 22

0 potencial educativo do contato com a natureza........................................ 26

Ecoturismo: atividade mercadológica, educativa, ou ambos? ........................ 34

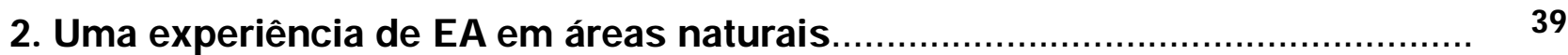

Local das atividades de Ecoturismo analisadas ....................................... 41

Atividades desenvolvidas e observação participante.................................. 44

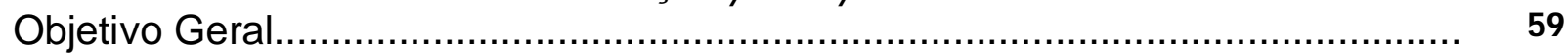

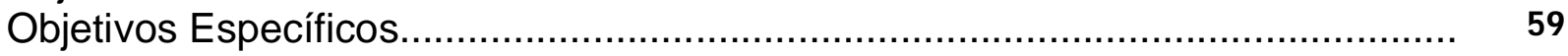

3. Estudos Exploratórios

Estudo 1: Quais são as motivações para visitas à natureza?....

Estudo 2: Quais são suas motivações para o comportamento pró-ambiente dos

Profissionais e Educadores Ambientais?

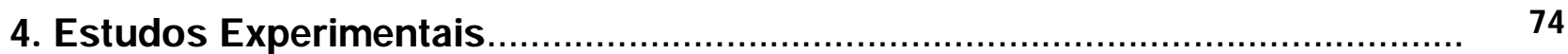

Estudo 3a: Mudanças medidas por Escalas de Avaliação de Sentimentos............ 74

Estudo 3b: Mudança de paradigmas: Desenvolvimento Sustentável $X$ Sociedades Sustentáveis.

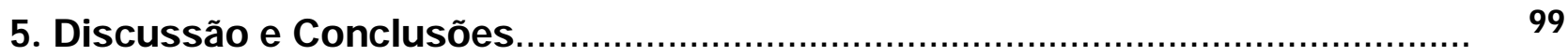

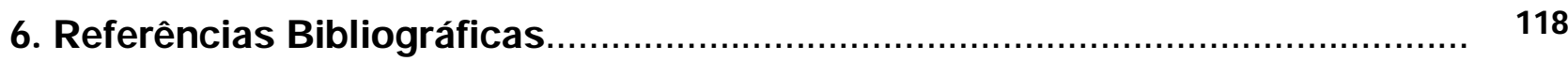

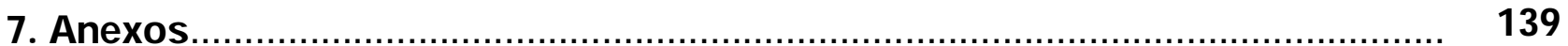


Às vezes, em dias de luz perfeita e exacta, Em que as coisas têm toda a realidade que podem ter, Pergunto a mim próprio devagar Porque sequer atribuo eu Beleza às coisas.

Uma flor acaso tem beleza? Tem beleza acaso um fruto?

Não: têm cor e forma

E existência apenas.

A beleza é o nome de qualquer coisa que não existe Que eu dou às coisas em troca do agrado que me dão. Não significa nada. Então porque digo eu das coisas: são belas?

Sim, mesmo a mim, que vivo só de viver, Invisíveis, vêm ter comigo as mentiras dos homens

Perante as coisas, Perante as coisas que simplesmente existem.

Que difícil ser próprio e não ser senão o visível!

Alberto Caeiro (13.03.1914) em: O Guardador de Rebanhos 


\section{1 \\ Introdução}

Designa-se como comportamento pró-ambiente (pro-environmental behavior) o conjunto de valores e ações que tornam os indivíduos conscientizados e os transformam em divulgadores e agentes de transformação social em busca da sustentabilidade e da melhoria da qualidade de vida, em questionadores das práticas individualistas e consumistas da sociedade, e em integrantes de uma busca coletiva pelo equilíbrio do meio ambiente e com o meio ambiente, e, eventualmente, em defensores da causa ecológica (STAPP et. al., 1969). Tanto a psicologia ambiental como a sociologia ambiental têm contribuído com estudos nesse tópico, principalmente no que se refere ao pressuposto de que mudanças nas atitudes em direção a comportamentos pró-ambiente são fundamentais para a sociedade lidar com os graves problemas ambientais da atualidade.

Para Corral-Verdugo et. al. (2004, p.43), "competência pró-ambiental" é a "capacidade de responder efetivamente às exigências de conservação do meio ambiente". Sendo as "exigências de conservação" os objetivos a alcançar para preservar o meio ambiente, a posse de habilidades ambientais permitiria aos indivíduos responder efetivamente sempre que as exigências ambientais correspondentes, sejam elas advindas da natureza ou dos seres humanos, estivessem presentes.

Mas, se desejável, como fazer aflorar o comportamento pró-ambiente? Essa pergunta, já formulada (CORRAL-VERDUGO, VARELA-ROMERO \& GONZÁLEZ-LOMELÍ, 2002; MILFONT, DUCKITT \& CAMERON, 2006; TANNER, 
1978; HEIMSTRA \& MCFARLING, 1978; MATSUSHIMA, 1992; CARVALHO, 2001) e cuja resposta interessa a todos os educadores ambientais, é tema deste trabalho.

Partindo das premissas de áreas do conhecimento que se dedicam a estudar o comportamento individual e social no que concerne à questão ambiental, e dos resultados de atividades de Educação Ambiental realizadas em áreas naturais, o presente trabalho tem por objetivo estudar e discutir algumas das variáveis capazes de transformar valores e gerar atitudes pró-ambiente, buscando encontrar as raízes dos processos que possam explicar porque as pessoas desenvolvem atitudes favoráveis à melhoria da conservação ambiental, principalmente o papel das visitas à campo.

A gênese desses comportamentos, suas características e motivações, bem como a metodologia adequada para avaliá-los, são temas de interesse de um grande número de pesquisas (PELLETIER, LEGAULT \& TUSON, 2006; DENG, WALKER \& SWINNERTON, 2006; HEATH, \& GIFFORD, 2006; WIIDEGREN, 1998; JOHNSON, BOWKER \& CORDELL, 2004; HERNÁNDEZ et. al., 2000; VILLACORTA, KOESTNER \& LEKES, 2003, CORRALIZA \& BERENGUER, 2000).

Uma Educação Ambiental efetiva tem de ser desenvolvida cuidadosamente, seguindo uma série de etapas numa direção definida. Contudo, tem sido difícil definir estas etapas, e a Educação Ambiental aparece muitas vezes como um campo difuso de experiências e resultados incipientes. O que significa exatamente "dar um significado ecológico" à educação? (CAPRA, 2001, RISSER, 1985; LI, 2000; FARINA A. \& BELGRANO, 2004).

O denominador comum entre as abordagens que serão aqui apresentadas é o comportamento das pessoas, visto como uma construção social sobre as possíveis predisposições biológicas. Optou-se, por utilizar uma metodologia que revele a consciência que os indivíduos têm das questões ambientais e seus valores a respeito.

Vários argumentos podem ser usados a favor da idéia de que existe uma

predisposição no ser humano para gostar da natureza viva. Os estudos sobre a relação entre seres humanos e animais apontam que desde muito cedo a criança tem um gosto por animais, e, inclusive, algumas correntes da psicologia usam os animais como auxiliares ou como cerne de procedimentos terapêuticos (LEVINSON, 1995; SAN JOAQUÍN, 2002; HUMPHRIES, 2003; MARTINS, 
2004). Edward Wilson (1984) criou a palavra "biofilia" para indicar a tendência, proveniente de nossa evolução como espécie, para gostar dos fenômenos da vida

(que, evidentemente, incluem a nós mesmos) (KELLER, 1993). Para Marin, Oliveira \& Comar (2005), a biofilia se manifesta não somente na busca de contato com outras formas de vida, mas numa forte simbolização a respeito delas, principalmente sobre os animais. "As simbologias são tecidas tanto na antropomorfização das imagens quanto na atribuição de diversos significados misteriosos e mitológicos, de onde ressurgem monstros e miscigenações da forma humana com formas animais" (MARIN, OLIVEIRA \& COMAR, 2005, p.3).

O termo topofilia, criado por Bachelard em 1957 na primeira edição da obra "A Poética do Espaço" (BACHELARD, 1993), foi utilizado por Tuan (1983) que a define como um sentimento afetivo entre o ser humano e um lugar, que se torna mais forte quanto mais esse lugar ou um meio ambiente estiver ligado a acontecimentos de cunho emocional ou for percebido como simbólico. "O que começa como espaço indiferenciado transforma-se em lugar à medida que o conhecemos melhor e o dotamos de valor" (TUAN, 1983, p.6). A biofilia se manifestará melhor e de forma mais marcada se os indivíduos estiverem em contato com aspectos do ambiente apropriados para a sua manifestação. O que torna uma pessoa mais afeiçoada à natureza, é a construção de uma atitude nascida da interação com locais onde os processos naturais estejam se manifestando. Pode-se facilitar sua formação, proporcionando ao indivíduo um grau marcado de autonomia em relação a determinadas normas sociais (NORDLUND \& GARVILL, 2002).

Marin, Oliveira \& Comar (2003) ao discutirem a importância das imagens construídas pelo ser humano a partir da sua relação com o meio, afirmam que, se a biofilia se caracteriza por suas raízes biológicas, a topofilia é marcada por aspectos culturais como afetividade, memória e experiência interativa. Quando uma pessoa é levada para um passeio no mar para ver golfinhos, pode buscá-los de barco por quase um dia inteiro. De repente eles aparecem mostrando o dorso durante 0 mergulho, e pode até ser que um deles, levantando a cabeça pareça estar olhando para o observador. Nesta simples experiência, que a põe em contato, por alguns 
segundos, com o desenrolar de uma trama natural, a pessoa capta aspectos importantes do fenômeno vivo que a preparam à, eventualmente, defender a preservação do meio ambiente, do mar, dos golfinhos. É difícil explicar o efeito de uma experiência tão simples como esta sem supor que exista um gosto pela natureza latente e talvez típico de nossa espécie.

Os momentos de interação com o mundo natural têm analogias com a experiência estética e com expressões artísticas que fazem referências aos elementos de uma natureza preservada (MARIN, OLIVEIRA \& COMAR, 2005). A idéia que sub-jaz este trabalho, adquirida através da realização de atividades de Educação Ambiental em áreas naturais, é que, se for proporcionado um contato apropriado com a natureza (por exemplo, pela experiência de entrar em uma mata, de respirar os aromas das folhas molhadas e ouvir a chuva caindo, de passar por uma enxurrada, por o pé no barro, de avistar um animal em suas atividades próprias) pode ser facilitada a aquisição ou o melhoramento de sentimentos positivos a respeito do que deve ser preservado e sobre porque é preciso preservar. Não é apenas através do sentimento ético de obrigação que se pode trabalhar o gosto pela natureza e pela conservação.

Em seu estudo, Kals, Schumacher \& Montada (1999) avaliaram o poder da afinidade emocional com a natureza através da análise de dois afetos muitas vezes analisados na pesquisa sobre o comportamento pró-ambiente: a indignação com a insuficiente proteção ao mundo natural (uma abordagem emocional relacionada com a responsabilidade), e a natureza do interesse (uma abordagem cognitiva). Testaram uma hipótese sobre o desenvolvimento da afinidade emocional para o mundo natural, analisando como estes afetos se relacionam às experiências passadas e presentes com natureza. Seus resultados confirmaram que a afinidade emocional com áreas naturais pode explicar o comportamento pró-ambiente, e reforçam a atribuição de importância dada às atividades de Ecoturismo.

Por levar pessoas de vida urbana para fazer uma viagem, não para um lugar de fantasia, mas para lugares que existem (ainda!), em sua pujança natural, o Ecoturismo pode constituir-se numa oportunidade de transformá-las 
em simpatizantes e/ou defensoras de uma nova lógica de utilização dos recursos naturais.

$\mathrm{O}$ presente trabalho tem três partes. $\mathrm{Na}$ primeira, faz-se um levantamento do pensamento ambiental no Brasil e no mundo, e sobre os princípios e as concepções da Educação Ambiental, além de apresentar um breve histórico e a definição do Ecoturismo, discutindo seu potencial como estratégia de conservação dos recursos naturais. Descreve-se, também, a participação do autor em atividades dirigidas de Ecoturismo realizadas ao longo de 16 anos. Na segunda parte apresentam-se os estudos empíricos realizados: (1) entrevistas feitas com visitantes de 10 áreas naturais do Brasil com objetivo de investigar as principais motivações que os levaram a viajar para essas localidades; (2) aplicação de um questionário à profissionais de Educação Ambiental a respeito de suas motivações pessoais e estratégias mais eficientes para mudanças de atitudes ambientalistas; (3) experimento em que foram comparados estudantes que viajaram ao Parque Estadual do Alto Ribeira PETAR com colegas que não viajaram, e em que foram avaliadas mudanças de conhecimentos, sentimentos, valores, atitudes e vieses paradigmáticos dos indivíduos que passaram por experiências de contato dirigido com a natureza.

$\mathrm{Na}$ terceira parte, são enunciadas considerações finais a partir dos resultados empíricos, e discutidas as hipóteses testadas, com sugestões para a continuidade dos trabalhos de Educação Ambiental através do Ecoturismo. 


\section{A Questão Ambiental}

Diversos movimentos sociais, apoiados por argumentos fornecidos pela ciência e amplamente divulgados pela mídia, vêm trabalhando no sentido de tentar reverter a degradação ambiental. Tais movimentos, chamados de "ambientalistas" convergem ao pretender levar a questão ambiental para além de seu caráter biológico, transformado-a numa questão social ligada ao modelo de desenvolvimento contemporâneo. Trabalham no sentido de se estabelecer uma ética que entende a natureza como um bem em si, acima dos interesses das sociedades de consumo.

O movimento ambientalista surge a partir da percepção da degradação da paisagem, que inicialmente é representada pela natureza como um ideal de pureza, do bom selvagem, o que estimula a sociedade, num primeiro momento, a criar suas primeiras Unidades de Conservação (MOL,1997). Este movimento cresce substancialmente a partir da segunda metade do século XX pela interferência dos que chamam a atenção para problemas decorrentes das tecnologias e produtos que o ser humano inventa e que prejudicam o meio ambiente. A crise ambiental introduz limitações que re-significam o curso do pensamento social, especialmente a partir dos anos de 1960, quando o mundo assiste a uma revolução social através dos movimentos contra-culturais (hippies, feminismo etc.), que fazem crítica aos padrões de consumo e propõem limites ao crescimento (Clube de Roma ${ }^{1}$ ). Surge o conceito de capacidade de suporte em ecologia e em seguida o conceito de sustentabilidade, como tentativa de compatibilizar o crescimento populacional humano com a preservação dos recursos (LEFF, 2000).

O "ecologismo" contemporâneo insere-se na sociedade como um fenômeno de contracultura, herdeiro das visões românticas dos europeus que alteram a compreensão iluminista de uma natureza transformada pela razão, e

\footnotetext{
${ }^{1}$ O Clube de Roma é uma organização internacional cuja missão é agir como catalisadora de mudanças globais, livre de quaisquer interesses políticos, econômicos, ou ideológicos. A organização busca analisar os problemas chave diante da humanidade. Seus trabalhos, como a publicação em 1972 do notório "Limits to growth", possuem significativo impacto no cenário político internacional.
} 
do imaginário sobre a América como paraíso natural. Esse movimento é fruto, também, da hostilidade da experiência urbana e suas inóspitas condições ambientais, que impulsionaram o surgimento de um sentimento estético e moral de valorização da natureza selvagem, e que se constituem nas raízes históricoculturais do ambientalismo contemporâneo (CARVALHO, 2001).

No que se refere ao surgimento dos sujeitos ecológicos, a expansão da consciência ambiental nos anos de 1970 reflete uma correspondência entre o que se vê na TV e no mundo real. A observação da degradação ambiental é o principal fator agregador e iniciador dessa consciência. Há uma passagem dos problemas ambientais para uma segunda escala de amplitude (chuva ácida, aquecimento global, buraco na camada de ozônio etc.) o que promove na sociedade uma percepção de crise. Esta tendência propõe que se imponham limites para a industrialização que, se controlada, poderia minimizar a poluição e os problemas ambientais. As Organizações Não Governamentais - ONGs passam a centrar seus discursos na idéia do conservacionismo e entendem como "vilã" de todo o processo a industrialização e sua face destruidora. Realiza-se uma grande coalizão ambientalista contra a sociedade de consumo. Fazem-se críticas contundentes ao papel da tecnologia como promotora da crise ecológica (MOL \& SPAARGAREN, 2000).

A globalização, materialização do atual modelo de desenvolvimento da sociedade de consumo, está sustentada por um grande volume de conhecimentos científicos e tecnológicos que impulsionam o processo de produção e circulação de mercadorias, sem alterar a sua centralidade, ou seja, a remuneração do grande capital e o lucro das grandes empresas. A ciência, as técnicas e as tecnologias, mais do que simples partes do processo de produção de mercadorias são faces constitutivas das relações sociais e desempenham papéis importantes na reprodução do modelo de desenvolvimento, representando instâncias de mediação das relações sociais locais e, também, na articulação entre os lugares e o global (FARIA, 2002).

Todo esse avanço científico e tecnológico de um mundo globalizado promove novas tendências na economia e gera uma sensação de que a 
conservação do meio ambiente e o desenvolvimento (nos moldes do capitalismo) são incompatíveis, e que os interesses dos países desenvolvidos nunca levarão em consideração as necessidades dos países pobres. Numa rede de necessidades como a que se modelou a partir da globalização, os países industrializados e aqueles em desenvolvimento dependem uns dos outros. A partir do Relatório Brundtland², foi convencionado que a proteção ao meio ambiente e promoção do desenvolvimento econômico são objetivos intimamente relacionados, e os países passaram a defender a possibilidade do "desenvolvimento sustentável". Nesta perspectiva, para que as economias nacionais cresçam e sejam promissoras, os recursos naturais devem ser conservados.

Mas, como a população em geral não tomou conhecimento do debate que culminou na elaboração desse documento, um dos aspectos desafiadores do movimento ambientalista, desde então, foi sair da fase do discurso meramente reivindicatório, para uma demonstração de soluções práticas, com maior apelo perante a opinião pública. É a percepção pública, fruto da disseminação do debate pelos atores envolvidos com o tema, que Hannigan (1995) define como "construcionismo social", o elemento fundamental para o crescimento do ambientalismo. A visão de construção social do problema se contrapõe ao fatalismo. A contribuição de atores sociais para a elucidação de causa e efeito dos problemas aciona movimentos de reivindicação das comunidades. Estabelece-se a partir daí uma credibilidade no discurso.

O respeito aos processos vitais e aos limites da capacidade de regeneração da natureza passam a ser balizadores das decisões sociais, reorientando os estilos de vida e hábitos coletivos e individuais, e, "juntamente

2 Documento intitulado "Nosso Futuro Comum", elaborado pela Comissão Mundial sobre o Meio Ambiente e Desenvolvimento e publicado em 1987, no qual desenvolvimento sustentável é concebido como "o desenvolvimento que satisfaz as necessidades presentes, sem comprometer a capacidade das gerações futuras de suprir suas próprias necessidades". Essa definição reafirma uma visão crítica do modelo de desenvolvimento adotado pelos países industrializados e reproduzido pelas nações em desenvolvimento, e que ressaltam os riscos do uso excessivo dos recursos naturais sem considerar a capacidade de suporte dos ecossistemas. 
com uma ética, se delineiam também uma racionalidade ambiental e um sujeito ecológico que se afirmam contra uma ética dos benefícios que rege o Homo oeconomicus e a acumulação nas sociedades capitalistas" (CARVALHO, 2001, p.37).

Esse é o cenário que nos ajuda a entender o movimento de ecologização que surge no final do século XX, com todas suas nuances. Ecologizar a sociedade e as políticas públicas passa a significar a introdução da variável ecológica onde antes só havia a preocupação econômica. Essa tendência enfatiza a importância dos empreendedores incorporarem o tema nas suas agendas para que possa haver a renovação ecológica. Coloca a premissa de que, numa sociedade reflexiva (BECK, 1993; GIDDENS, 1991, 1998), é possível que os agentes passem e se modernizar no sentido de provocar menos impacto. Mas essa nova visão não mexe essencialmente com o paradigma central do capitalismo; apenas otimiza os processos produtivos.

Outras características desse processo de ecologização são o reforço do papel do Estado como agente regulador e normativo do mercado e a concepção de que é melhor prever os impactos do que consertar o mundo. Pequenas mudanças no modo de vida devem acontecer para que haja sustentabilidade, caso contrário, segundo os ambientalistas, o consumo desenfreado de recursos pode levar o sistema civilizatório à autodestruição. A ética de desenvolvimento deve incluir uma prudência ambiental (Princípio da Precaução ${ }^{3}$ ) em proteger a biodiversidade e a equidade de acesso a um ambiente saudável para esta e as futuras gerações (ética intergeracional) (ATTFIELD, 1998).

Os indicadores de crescimento econômico, do tipo "renda per capita" ou "produto interno bruto", são aos poucos substituídos por outros como o Índice de Desenvolvimento Humano (IDH), bem mais qualitativos (por incorporar

${ }^{3}$ Originário da política ambiental européia da década de 1970, o Princípio da Precaução foi definido na Conferência RIO 92 como "a garantia contra os riscos potenciais que, de acordo com o estado atual do conhecimento, não podem ser ainda identificados". Este Princípio afirma que a ausência da certeza científica formal, a existência de um risco de um dano sério ou irreversível requer a implementação de medidas que possam prever este dano. 
expectativa de vida, nível de instrução e nível de renda) e surgem grandes controvérsias em relação ao próprio conceito de crescimento. Isso porque esses indicadores medem um fluxo de renda sem descontar a depreciação dos estoques, ou seja, aufere taxa de crescimento sem considerar a depleção dos recursos naturais nem a exploração dos recursos humanos (SAFATLE, 2006). Os critérios econômicos, sociais e ambientais são três eixos do mesmo problema e geram sociedades diferentes. O conceito de desenvolvimento sustentável faz surgir novos modelos de economia que criticam a idéia do crescimento zero e defendem que para haver sustentabilidade deve haver crescimento econômico (JACOBS, 1991). Mesmo porque, o refreamento do crescimento econômico não produz necessariamente sustentabilidade, e um coeficiente que meça o crescimento de um produto nacional e o quanto de impacto ele produz, pode resultar em zero.

O desenvolvimento se torna assim objeto de discussão e a natureza o fator crítico a ser pensado (SACHS, 1997). Quais são as reais necessidades da classe média globalizada consumista? As imagens da Terra vista do espaço deram a dimensão global ao problema e trouxeram a questão sobre quem paga a conta da degradação ambiental. Sem dúvida uma política de limitação sempre implica numa perda de poder, mesmo que isso seja feito em nome de uma nova prosperidade. O que está colocado é a busca de um modelo civilizatório menos depredatório.

$\mathrm{Na}$ área acadêmica, a questão ambiental impõe ao pensamento científico uma nova forma de busca de conhecimento, uma racionalidade que parte da premissa de que os problemas podem ser mais complexos do que se supunha. O processo de construção dessa racionalidade ambiental revela os limites que existem para se conseguir uma fonte de síntese analítica, devido aos limites das formas convencionais de conhecimento (LEFF, 1994).

A intenção epistemológica dos especialistas no campo ambiental é a de constituir-se em um novo saber (identificado por LEFF - 1998a, 1998b, 2000 como uma racionalidade ambiental) que, alternativo e crítico "à razão instrumental, cartesiana e cientificista, pretende legitimar um corpus de 
fundamentos e de metodologias capaz de apreender a complexidade das interações sociedade-natureza" (CARVALHO, 2001, p.156).

No entanto, apesar da maior visibilidade da questão ambiental em todos os segmentos da sociedade, vale considerar que a preocupação com o futuro ainda tem sido insuficiente para mudar o presente, relegando a prática da sustentabilidade, tão defendida no contexto descrito até aqui, à retórica. Além disso, esses novos valores têm sido incapazes de alterar o modo de produção e consumo, que passou a assumir grandes dimensões com o processo de globalização.

O novo conceito cultural de sustentabilidade, bem distante de ser amplamente aceito, não é compreendido, endossado ou seguido pelos indivíduos na sociedade. A razão do conceito de sustentabilidade não ter sido ainda abraçada nem no nível individual nem no coletivo, é que as pessoas não perceberam as relações entre os domínios do social, do econômico e do ambiental. Problemas ambientais são entendidos pelas pessoas como problemas de saúde que podem se tornar problemas de aprendizagem etc.: todos os domínios interagem (UZZELL, 2004).

Leis (1998) classifica as posições ecológicas em biocêntricas, preservacionistas e românticas (de retorno à natureza) por um lado e antropocêntricas, utilitarista e de conquista da natureza por outro, maniqueísmo progressivamente abandonado nos anos de 1980, quando o ambientalismo ingressou em uma fase que denominou "multissetorial" (coexistência de vários setores: governamentais, empresariais, científicos etc.). Para 0 autor, 0 ambientalismo não apela nem confia em soluções técnicas ou em determinismos históricos para cuidar da natureza, mas, na procura do 'justo meio' entre os diversos radicalismos existentes, apela e confia em mudanças de atitudes básicas dos seres humanos. $O$ autor conclui seu pensamento afirmando que "os desafios ambientais devem ser colocados no contexto de um esforço abrangente para onde possam convergir os conhecimentos e as práticas baseadas no domínio técnico da natureza, com vivências da filosofia, da religião, da arte, e até do senso comum" (LEIS, 1998, p.101). 
A invenção ecológica (CARVALHO, 2001), pode ser considerada um resultado direto do processo de construção social da questão ambiental (HANNIGAN, 1995), e em ambos os casos estamos falando de um processo cultural, do surgimento do cenário descrito acima, onde a chamada consciência ambiental ganha força na sociedade, sendo praticamente unânime a opinião de que apenas um processo de educação voltado para a transformação dos valores e atitudes individuais poderá conduzir a humanidade ao encontro de alternativas sustentáveis.

\section{Educação Ambiental: um campo em construção}

A Educação Ambiental (EA) é um campo em construção, tanto no que se refere às políticas públicas (sejam elas governamentais ou realizadas por segmentos específicos da sociedade) quanto na produção acadêmica de conhecimentos. A insipiência da área é solo fértil para as mais diferentes abordagens conceituais, práticas pedagógicas e ações mobilizadoras da sociedade, o que de certa forma enriquece a diversidade de iniciativas, mas enfraquece sua eficiência enquanto estratégia coletiva. Para compreender sua origem será feita agora uma breve incursão na sua trajetória histórica e serão apontadas as principais correntes que surgiram nesse processo. Apesar do significativo avanço no campo das idéias, em debates que se iniciaram nos anos de 1970, a EA, apesar da grande produção acadêmica brasileira, ainda carece de pesquisas que possam contribuir com a compreensão de seus fundamentos e testar sua eficiência enquanto atividade transformadora.

Quando se fala do papel das ciências no tratamento das questões relativas ao meio ambiente, o que está em jogo é uma estratégia epistemológica centrada na busca de uma nova racionalidade dentro de pressupostos tradicionais, que possibilite uma determinada forma de apreensão do conhecimento. Trata-se de uma abordagem dualista.

Para se implantar uma nova racionalidade é preciso romper obstáculos epistemológicos e barreiras institucionais, e avançar sobre diferentes formas de elaboração do conhecimento, vinculado-as à solução prática de problemas e às 
futuras políticas e estratégias de desenvolvimento. A rejeição de muitas pessoas às atitudes e aos comportamentos pró-ambiente deve ter a ver com a consciência ambiental e os valores culturais que dominam a nossa sociedade (UZZELL, 2004). A EA surge para mudar essa realidade.

Foi partir da "Conferência das Nações Unidas sobre Desenvolvimento Humano" (Conferência de Estocolmo, 1972) que a EA ganhou destaque em todo o mundo, sendo que no Brasil esta discussão só se estabeleceu com força a partir dos anos de 1980. A realização da "Conferência das Nações Unidas para o Meio Ambiente e Desenvolvimento" (a Rio/92) e a publicação do Tratado de Educação Ambiental Para Sociedades Sustentáveis e Responsabilidade Local, pelas ONGs reunidas no Fórum Global (GRUPO DE TRABALHO DE EDUCAÇÃO AMBIENTAL DAS ORGANIZAÇÕES NÃO-GOVERNAMENTAIS NO FÓRUM GLOBAL, 1992), contribuiu significativamente para o estabelecimento das bases para a implantação de políticas e programas voltados a uma nova consciência da sociedade em relação a sua interação com o meio. No campo acadêmico, no entanto, muito se escreveu sobre EA, mas, apesar da razoável quantidade de experiências e idéias que foram sendo publicadas, pouco se avançou no sentido de elaboração de atividades eficazes e inovadoras que pudessem ser aplicadas nos setores formais e informais da educação.

Nesses e em outros diversos congressos que vêm ocorrendo desde a década de 1970, ficou clara a necessidade de se implantar uma EA que faça emergir valores que tornem a sociedade humana mais justa, tais como a ética, a responsabilidade, a honestidade, a amizade, o respeito à vida e, entre outros, a democracia. Todos esses princípios são apontados como a base que define a sua prática. Portanto, o resgate desses valores deve ser realizado pela EA. A educação clássica formal não vem cumprindo seu papel, pois parece estar preocupada apenas com um ensino centrado nos conteúdos conceituais. A EA veio aliar a teoria à prática, na tentativa de resgatar os valores já mencionados.

$O$ efeito de repetição confere aos documentos internacionais certo caráter de mito de origem. Dessa forma, eles passam a ser os fiadores da 
legitimidade pretendida pela $\mathrm{EA}$, tanto para o público interno quanto para efeito de reconhecimento externo, operando como um corpus discursivo unificador de uma memória comum (CARVALHO, 2001).

Diante da gravidade da degradação provocada pela ação humana, parece razoável que se coloque a questão ambiental como um saber reintegrador, multiplicado nas suas possibilidades pelos muitos saberes existentes na sociedade, associados a um mundo em busca de soluções para a crise, passando por um projeto de desconstrução de uma lógica dominante e a criação de uma nova racionalidade ambiental. Esse é o grande pressuposto da Educação Ambiental, que a remete, inicialmente, para o campo filosófico.

Muitos educadores ambientais inspiram sua atuação no pensamento do físico Fritjof Capra, que em seu livro "As Conexões Ocultas" (dentre outros), desenvolve o que ele chama de uma "compreensão sistêmica e unificada" que integra as dimensões biológicas, cognitivas e sociais da vida e demonstra claramente que ela, em todos os seus níveis, é inextricavelmente interligada por redes complexas (CAPRA, 2002). No entanto, quando se fala em educação, da forma como ela se institucionalizou na sociedade, normalmente se atrela as ações pedagógicas à concepção bidimensional da natureza, um legado atribuído a Descartes que fomenta um distanciamento do meio ambiente natural, enfatizando a divisão entre espírito e a matéria que o levou a uma concepção do universo como um sistema simplesmente mecânico. Tal concepção mecanicista do mundo ainda perdura na base da maioria das nossas ciências e continua a exercer uma enorme influência em muitos aspectos de nossa vida, principalmente na fragmentação de nossas disciplinas acadêmicas (CAPRA, 1995). Destes pressupostos deriva a corrente conhecida como "Alfabetização Ecológica", que, ao assumir uma visão sistêmica da vida, tem sua fundamentação teórica baseada na teoria dos sistemas vivos. A EA proposta pelos seus seguidores tem princípios e critérios que perpassam várias disciplinas, sendo um espaço de diálogos, de encontros entre os múltiplos saberes e fazeres. 
Outro pensador que empresta sua visão de mundo e é bem recebido pelos educadores ambientais é Edgar Morin. Como na alfabetização ecológica, seus simpatizantes defendem que, devido a uma suposta crise do pensamento positivista, visões não cartesianas vêem se estabelecendo nas ciências, a maioria apontando para uma análise que considere os múltiplos aspectos da complexa realidade do mundo. O termo "complexidade" (MORIN, 2001) vem criando a necessidade de argumentação a partir da premissa de que os fenômenos é que são complexos, quando, de fato, a dificuldade em compreender a complexidade está nos limites de capacidade de abordagem do pesquisador. Pensá-la implica na busca das diversas variáveis correlacionadas ao fenômeno que se observa, e isto é especialmente difícil quando estamos falando de comportamentos humanos. A chamada "abordagem holística" é evocada pelos educadores ambientais que coadunam com essa corrente. Contribuições transdisciplinares podem levar ao desenvolvimento de uma nova terminologia, a conceitos inovadores e a um novo conhecimento. Esse é um importante desafio para a ecologia humana no início de um novo milênio (LAWRENCE, 2004). O mesmo raciocínio vale para a psicologia ambiental, a educação e a sociologia ambiental.

Mas, se a EA é um meio para a busca de uma relação diferente do ser humano com a natureza, como convencer as pessoas de que há uma crise ambiental se o tema é tão complexo (ou sistêmico) que não pode ser entendido?

Seja com Capra ou Morin, a EA se alimenta de idéias que the são emprestadas e que se adeqüam muito bem aos ideais de um grande grupo de educadores ambientais. Mas, apesar de grande abstração que esses autores conferem à área, há ainda uma falta de sistematização do conhecimento, ou, quando muito, há o mero relato das experiências que os especialistas acumulam ao longo de seu percurso. O saber ambiental, principalmente no que se refere à proposição de práticas educativas testadas em pesquisas controladas, ainda apresenta uma fragilidade epistemológica. A EA surge das exigências do mundo prático e não está embasada num corpo de 
conhecimentos sistematizados, como exige a almejada mudança de paradigma epistêmico e pedagógico (CARVALHO, 2001). Apesar de muitos programas educativos implantados mostrarem resultados eficientes, no Brasil poucos foram sistematicamente avaliados, comprovando que os resultados eram decorrentes do programa e não de outras variáveis (PADUA, 1997). Sua legitimação se dá no "fazer", e seu caráter de voz contra-hegemônica dentro da racionalidade contemporânea expõe os limites do projeto moderno de esclarecimentos e sua expressão nos saberes disciplinares. Assim a EA tem sua validação exclusivamente calcada "pelo reconhecimento da problemática ambiental na esfera pública e pela força dos atores sociais que são seus portavozes" (CARVALHO, 2001, p.157).

Essa constatação sugere que a realização de estudos controlados pode avançar no sentido da melhor compreensão sobre a gênese e permanência de comportamentos pró-ambiente, anseio final da EA. Quais seriam as condições necessárias para se apreender as diferentes compreensões do real (biológico, físico, simbólico)? Para que se avance sobre a resposta a essa pergunta é preciso a realização de mais pesquisas empíricas sobre o papel da emoção para a transformação de atitudes (KALS, SCHUMACHER \& MONTADA, 1999).

A EA tem como um de seus objetivos formar cidadãos conscientes de sua relação com a natureza e com seu habitat. Diante disso se conclui que a $E A$, independente da metodologia, deve primar pela formação de pessoas conscientes de seu papel e de sua relação com o meio ambiente, de modo que almejem a sustentabilidade, ajam na busca de soluções para o uso racional dos recursos naturais, de modo que as futuras gerações possam também usufruílos. A educação e áreas afins das ciências relacionadas com a ecologia elaboraram os fundamentos básicos da sua proposta pedagógica, que são: conscientização, mudança de atitude, desenvolvimento de competências, capacidade de avaliação e participação dos educandos (REIGOTA, 1998)

Diversos têm sido os autores que, de uma forma ou outra vêm discutindo algumas das bases teóricas da Educação Ambiental, dentre os quais se pode citar Matsushima (1992), Dias (1993), Viezzer \& Ovalles (1995), Brasil 
(1998), Cascino, (1999), Guimarães (2004), Gigliotti (1990), Mendonça (2000), Stapp et al. (1969), Simmons (1991) e Padua $(2000,2001)$.

A EA realiza-se através de dois tipos de processos: (a) a educação informal: atividades de contato com ambientes naturais e campanhas populares que visem à formação de atitudes que possibilitem a preservação dos recursos (fauna, flora, rios, matas etc.) e a correção de processos degenerativos da qualidade de vida na terra (poluições do ar e da água, enchentes, chuvas ácidas, mudanças climáticas etc.). Via de regra envolve agentes comunitários, profissionais liberais e os meios de comunicação de massa; e (b) a educação formal ou escolar: atuação curricular, tanto no planejamento quanto na execução de currículos, realizada pela rede de ensino.

No caso do ensino formal, o ideal seria a EA abordar em profundidade a miríade de fatores que moldam de forma cada vez mais irreversível o rumo e os caminhos de nossa sociedade, caso contrário, 'ambientalizar' a educação se torna um empreendimento estéril. Não basta envidar esforços como sociedade, e/ou ensinar professores a planejar tecnicamente parques, reservas, novas áreas de preservação ou o espaço urbano (BRÜGGER, 2004). No entanto, a EA na escola assume, quase sempre, um caráter essencialmente informativo que dificulta a real compreensão dos fenômenos estudados. O programa é extensivo, levado a cabo de forma detalhista e, freqüentemente, exige do aluno processos contínuos de memorização. Os fenômenos abordados parecem não ter relações entre si e pouco é mostrado de sua inserção na vida do jovem estudante. Tudo isso faz com que o estudo seja algo muito pouco interessante para o aluno, assim como para o professor.

A EA não formal visa propiciar o aumento de conhecimentos, mudança de valores e o aperfeiçoamento de habilidades, que são condições básicas para que o ser humano assuma atitudes que estejam em harmonia como o meio ambiente. Sorrentino (1998), numa análise dos tipos de projetos encaminhados para a busca de financiamento e parcerias, publicados ou apresentados em encontros, faz uma tentativa de sistematização classificando-os em quatro grandes correntes: "conservacionistas", "educação ao ar livre", "gestão 
ambiental" e "economia ecológica", segundo "suas tendências voltadas ao engajamento no movimento ambientalista, ao Ecoturismo e suas vertentes, às lutas nos movimentos por liberdades democráticas e à busca do 'desenvolvimento sustentável', respectivamente" (SORRENTINO, 1998, p.2728) Considera, ainda, a existência de quatro conjuntos de temas e objetivos com os quais os projetos se identificam: biológicos, espirituais/culturais, políticos e econômicos. Conclui que os grandes desafios para os educadores ambientais são, por um lado, o resgate e o desenvolvimento de valores e atitudes, tais como "confiança", "respeito mútuo", "responsabilidade", "compromisso", "solidariedade" e "iniciativa" e, por outro, "propiciar o desenvolvimento de habilidades individuais capazes de conquistar espaços para a geração de renda e empregos que fomentem e sejam fomentados por uma economia voltada à construção de sociedades econômica, ecológica cultural, espacial e socialmente sustentáveis" (SORRENTINO, 1998, p.31).

\section{Educação Ambiental para o Desenvolvimento Sustentável ou} Educação Ambiental para as Sociedades Sustentáveis?

O mais recente debate sobre concepções paradigmáticas referentes à Educação Ambiental se estabeleceu quando surgiram, na Unesco, os primeiros sinais de querer substituí-la por "Educação para o Desenvolvimento Sustentável". Nesse processo, colocaram-se argumentos contra e a favor. Com a decisão de se comemorar o "Decênio das Nações Unidas da Educação para o Desenvolvimento Sustentável" (2005-2014), iniciou-se um antagonismo que se manifestou com força na Iํ Conferência Internacional sobre a Educação para o Desenvolvimento Sustentável ocorrida em maio 2004, em Braga - Portugal (GONZALEZ-GAUDIANO, 2007). Desde então, diversos autores começaram a contrapor os conceitos de "Desenvolvimento Sustentável" e "Sociedades Sustentáveis" (TILBURY, 1995). O conceito de Desenvolvimento Sustentável ocupou posição central dentro do ambientalismo, especialmente, após a publicação do Relatório Brundtland (VIOLA \& LEIS, 1995), sendo uma mera 
tentativa de ajustar as sociedades ao modo de reprodução social capitalista, o que dificilmente evitaria a humanidade de caminhar para a crise ecológica global (LOUREIRO et. al., 2005). O termo, até hoje ambíguo, encerra múltiplas interpretações e controvérsias no cenário mundial e, ainda que as ideologias fossem duvidosas, acabou se consagrando para além do ambientalismo, estando presente em diversas outras áreas do conhecimento (MEIRA \& SATO, 2005).

O mais importante dilema oriundo do conceito de Desenvolvimento Sustentável é o fato de ele se transformar em alternativa do desenvolvimento dominante e o risco de contradizer os pressupostos ideológicos de setores de sua base político-social. Sinal disso é a sua rápida aceitação por diferentes perfis, tais como, economistas, acadêmicos, ambientalistas, políticos etc., o que dá um caráter polissêmico ao conceito (PEDRINI, 2006). Busca-se a debilidade da Educação Ambiental para reforçar a importância de uma educação dirigida ao capital, retirando a autonomia e liberdade da aprendizagem (JICKLING 1992, apud MEIRA \& SATO, 2005).

Uma análise mais aprofundada do termo "Desenvolvimento Sustentável" revela uma falta de consenso, não somente quanto ao adjetivo 'sustentável', como também quanto ao desgastado conceito de 'desenvolvimento'. O seu uso recorrente nos discursos governamentais e nos preâmbulos de projetos de investimento a serem financiados por instituições bi e multilaterais, transformaram o termo numa "palavra mágica" ou um fetiche para os mais diversos círculos e grupos sociais (DIEGUES, 1992).

O conceito de Sociedades Sustentáveis talvez seja mais adequado que o de Desenvolvimento Sustentável, pois nelas é possível se definir padrões de produção e consumo e o seu bem-estar derivado de sua cultura, de seu crescimento histórico e do seu ambiente natural. Também o conceito de Sociedades Sustentáveis subtende a existência de uma grande diversidade de modos e padrões de qualidade de vida, algumas vezes bem diferentes daqueles apregoados pelas sociedades industrializadas (DIEGUES, 1996). 
O grande avanço ao se adotar o conceito de Sociedades Sustentáveis, conforme ele aparece citado nos princípios da Carta da Terra (Tratado de Educação Ambiental para Sociedades Sustentáveis e Responsabilidade Global ${ }^{4}$ ), é que elas se mensuram por indicadores de qualidade de vida (saúde, longevidade, maturidade psicológica, educação, ambiente limpo, espírito comunitário e lazer) em oposição ao puro índice de consumo material (FERREIRA, 2005).

O maior desafio encontrado para se alcançar a sustentabilidade é a ruptura com o paradigma dominante que ainda é a Educação para o Desenvolvimento Sustentável. Só a Educação Ambiental para as Sociedades Sustentáveis pode contribuir para o equilíbrio entre o ser humano e a natureza, desde que "se construa uma ética ambiental que assegure uma educação sistematizada, vinculada ao contexto cultural da comunidade, considerando, pelo menos, os aspectos políticos econômicos, sócio-culturais, científicos, tecnológicos e éticos" (PEDRINI, 2006a, p.8).

A EA, ao se esquecer de lançar uma perspectiva que o desenvolvimento possui limites ecológicos e culturais de enorme envergadura, inadvertidamente, permitiu-se ser percebida como mero instrumento da gestão ambiental, prometendo solucionar todos os problemas ambientais (MEIRA \& SATO, 2005).

Há uma grande controvérsia entre "o campo do ambientalismo, compreendido como possibilidade de solucionar o problema através do mercado neoliberal; e o campo do ecologismo, cujo enfoque demanda uma mudança estrutural da sociedade como premissa para enfrentar a crise ambiental" (CARIDE \& MEIRA, 2001, apud MEIRA \& SATO, 2005, p.22).

\footnotetext{
${ }^{4}$ Construída pela sociedade civil durante as atividades da Rio-92, na Jornada Internacional de Educação Ambiental.
} 


\section{A importância das Pesquisas em Educação Ambiental,}

\section{Percepção, R epresentações e Psicologia Ambiental}

Apesar da sua importância, poucos educadores ambientais brasileiros divulgam seus trabalhos, ou o fazem de maneira pouco eficiente, pela escassez de periódicos e mesmo pela falta de hábito de publicar experiências. Quando há divulgação, na maioria dos casos, o que se observa são modelos já estabelecidos, que apresentam as mesmas reflexões e são poucos os que contribuem de fato para a busca de estratégias práticas para a implantação de programas inovadores e que partam de novos pressupostos conceituais. Apesar da popularidade que the conferiu a Rio/92 e do desenvolvimento de muitas práticas de diferentes características, seja na escola ou fora dela, o aprofundamento e a compreensão do que é a Educação Ambiental são deficientes, deixando as perguntas de como e por que fazê-la em aberto (REIGOTA, 1998). Junqueira \& Neiman (2007) (dentre outros), fizeram uma tentativa de reverter essa situação, ao promover a divulgação das experiências de pessoas e instituições que trabalham com Educação Ambiental no Brasil, mas ainda há uma carência de trabalhos empíricos, bem controlados e avaliados.

Reigota (2007) realizou uma pesquisa sobre a produção acadêmica brasileira em EA no período compreendido entre 1984 e 2002, que revelou a existência de pelo menos uma tese de livre-docência, 40 de doutorado e 246 dissertações de mestrado abrangendo diversos temas ambientais, concepções pedagógicas e políticas. Os principais temas abordados foram: as relações entre natureza e cultura, crise ambiental urbana e ecossistemas específicos. 0 estímulo ao processo de participação social visando à construção de uma sociedade democrática e sustentável é o aspecto político mais enfatizado, sendo a EA considerada um processo que pode ocorrer em todos os espaços de aprendizagem e estar presente no currículo de todas as disciplinas.

Ao analisar os trabalhos apresentados no Vo Fórum Brasileiro de Educação Ambiental, realizado em 2005, em Goiás, Lustosa, Matos \& Loureiro 
(2007) concluíram que a EA é um campo em crescimento, que representa o encontro de uma diversidade muito grande de pessoas. Os trabalhos apresentados no encontro incluem projetos em comunidades agrícolas e urbanas, em escolas, em Unidades de Conservação e dentro de instituições públicas. Os principais temas se referem a questões sobre o lixo, organização de redes, ecologia na sala de aula, relações interpessoais em ambientes de trabalho, e gerenciamento de Unidades de Conservação. No entanto, a maioria dos trabalhos analisados se limita a apresentar projetos, não esclarecendo muitas vezes o seu objetivo e a sua perspectiva teórica. Alguns dos trabalhos apresentados deixam claras a sua intenção e visão de EA, mas a maior parte carece de aprofundamento e posicionamento.

Há muitas perguntas ainda sem respostas na EA: Como conseguir a conscientização almejada por tantas correntes complementares? Quais atividades, vivências, terapias, ou outras experiências pessoais podem contribuir com a formação do cidadão ambientalmente competente? Qual o modus operantes mais eficaz para a transformação da sociedade? Qual a praxis mais recomendada?

À essas perguntas, poucas respostas foram dadas, sendo raros os trabalhos que apresentam propostas práticas com embasamento conceitual (GUIMARÃES, 1995; DIAS, 1993; VIEZZER \& OVALLES, 1995; CORNELL, 1987, 1989; MATSUSHIMA, 1992; NEIMAN \& MOTTA, 1991; BOLSCHO et. al., 1990; JUNQUEIRA \& NEIMAN, 2007; KALS, E., SCHUMACHER, D. \& MONTADA, 1999; ALLEN \& FERRAND, 1999; MILFONT, DUCKITT \& CAMERON, 2006; entre outros). A maioria dos tratados sobre Educação Ambiental não é objetiva nesse aspecto, justamente porque as metodologias ainda não foram encontradas e estão sendo elaboradas em conjunto, por aqueles que se interessam e se dedicam a essa atividade no Brasil.

É dentro desse contexto que muitas áreas do conhecimento podem vir a contribuir na investigação psicológica do fenômeno educativo, partindo de novos pressupostos ainda não compreendidos na busca de formulações pragmáticas. 
Conhecer a estrutura dos comportamentos pró-ambiente e as condições que tornam possível sua emergência permite o desenvolvimento dessa capacidade nos indivíduos. Assim, um passo fundamental para seu desenvolvimento é a compreensão de suas características relevantes como uma capacidade humana (CORRAL-VERDUGO, et. al., 2004). Esse é um dos objetivos da psicologia ambiental, que pode ser definida como o estudo das interações entre os indivíduos e aspectos relevantes do seu ambiente (DARLEY \& GILBERT, 1985). Ou seja, parte do pressuposto que os indivíduos, ao interagirem com o meio físico (espaço) e social (lugar, território), podem desenvolver diversas formas de comportamento diante de estímulos e situações ambientais. A EA, por exemplo, pode incluir nos seus discursos e práticas diversos estímulos capazes de encorajar os comportamentos pró-ambientais (CORRAL-VERDUGO, et. al., 2004).

Freqüentemente encontram-se confusões entre os conceitos de percepção e representação que são tidos como processos psicológicos similares nos estudos sobre a relação ser humano com a natureza. $O$ entendimento da interação do ser humano com o ambiente, solidificada em bases muito complexas, tem representado um estímulo para pesquisas de percepção ambiental. Essa percepção tem sido estudada, na maioria dos casos, mediante o levantamento de conceitos de meio ambiente e dos referentes a fenômenos e problemas ambientais (MARIN, OLIVEIRA \& COMAR, 2003). A palavra "percepção" vem do latim perceptio, que é o ato de perceber, ação de formar mentalmente representações sobre objetos externos a partir dos dados sensoriais. O estudo dos processos mentais relativos à percepção ambiental pode ser entendido "como um processo mental de interação do indivíduo com o meio ambiente que se dá através de mecanismos perceptivos propriamente ditos e, principalmente, cognitivos" (DEL RIO \& OLIVEIRA, 1997, p.3).

A representação, neste contexto, atua como um prolongamento da percepção porque a introduz num sistema de significação representativo, envolvendo a diferenciação entre os significantes que podem ser as formas de 
linguagem ou imagens, gestos, desenhos e os significados que compreendem os espaços (DEL RIO \& OLIVEIRA, 1997).

Merleau-Ponty (1999) propõe que a percepção é formada pelos sentidos, isto é, através dos sentidos podemos perceber o mundo e nós mesmos e, a partir daí mudarmos. O autor afirma que percebemos através de associações e substituições que fazemos com nosso passado, com palavras, com as pessoas, com os lugares e com os objetos.

Castoriadis (1999) ao contrário de Merleau-Ponty, afirma que a percepção não é separável da imaginação, ainda que não possa ser reduzida a esta. Para ele, há uma interdependência intrínseca na relação do imaginário com a apreensão do real, de maneira que no momento da leitura dos sentidos, o universo das imagens direciona $o$ ato perceptivo e se diluem nas informações que chegam puras ao racional humano.

A psicologia ambiental, ao se debruçar sobre o estudo das representações sociais, do simbólico e da construção social do discurso ecológico, pode fornecer elementos para a compreensão morfológica e funcional dos comportamentos pró-ambiente e seus eliciadores? Quanto do imaginário de "paraíso-natural", do "mito criador" (CHAUí, 2000) está presente no movimento dos cidadãos urbanos em direção à "paz" e ao "descanso" dos parques e reservas observado nos dias atuais e explorado pelo mercado do Ecoturismo? A análise do comportamento humano, nas suas mais variadas vertentes, dentre elas a afetividade e o encantamento proporcionado pelo contato com a natureza, constitui um vasto campo de pesquisa que ainda merece um melhor tratamento no que se refere a sua ligação com a Educação Ambiental.

\section{O potencial educativo do contato com a natureza}

Os estudos sobre as crenças e atitudes do público em relação ao ambiente e à natureza constituem atualmente uma parte muito substancial da literatura que as ciências sociais dedicam a assuntos ambientais. Em periódicos como Environment and Behavior, J ournal of Environmental Psychology, ou 
J ournal of Social Issues essa linha de investigação vem originando numerosas publicações enquadradas por modelos e conceitos da psicologia, da sociologia, da ciência política e da antropologia (CASTRO, 2003). Trata-se de uma literatura que começa a ganhar uma importância crescente a partir do final da década de 1970, procurando acompanhar aquela que por essa altura começava a ser conhecida como a "preocupação ambiental" (environmental concern) do público. Assim, na tentativa de descrever e compreender uma preocupação ambiental cada vez mais visível, as ciências sociais começaram a investir maiores esforços nesta área.

Muitos foram os trabalhos realizados e diversos os conceitos estudados nos últimos 30 anos, dos quais vale destacar: a preocupação ambiental (HEATH \& GIFFORD, 2006; ARAGONÉS \& AMÉRIGO, 1991); o grau de conhecimento (consciência) sobre assuntos ambientais (JOHNSON, BOWKER \& CORDELL, 2004; KRAUSE, 1993); a percepção de participação pessoal nos problemas ambientais (HEATH \& GIFFORD, 2006; BALDASSARE \& KATZ, 1992); o ambientalismo (FERREIRA, 1996); a apatia em relação a assuntos ambientais (THOMPSON \& BARTON, 1994); as crenças em relação ao ambiente (CRESPO \& LEITÃO, 1993; MILFONT, DUCKITT \& CAMERON, 2006, WYSOR, 1983); as visões ecológicas de mundo (DUNLAP et. al., 2000; WIIDEGREN, 1998; STERN, et. al. , 1995); as racionalidades culturais e os mitos da natureza (DIEGUES, 1992; STEG \& SIEVERS, 2000). Mas como uma "preocupação ambiental" se transforma em "atitude pró-ambiente"?

Algumas pesquisas realizadas nas últimas décadas vêm apontando 0 potencial educativo das visitas a áreas naturais, pois essas atividades otimizam a assimilação e permanência de conteúdos conceituais e estimulam a curiosidade dos participantes (ALVARENGA \& NOGUEIRA-FILHO, 2005; JACOBSON \& PADUA, 1992; MERGULHÃO, 1998; PELLETIER, LEGAULT \& TUSON, 1996; KALS, SCHUMACHER \& MONTADA, 1999; FINGER, 1994).

Para Quaranta-Gonçalves \& Soares (2004, p.2),

"práticas educativas em ambientes ricos em estímulos sensoriais, como as trilhas, criam a oportunidade para seus participantes utilizarem seu corpo 
encarnado para perceberem o meio ambiente, elaborarem-no e recriarem-no, pelo encadeamento das experiências perceptivas, interagirem e dialogarem com ele, numa relação de troca entre o ambiente e os sujeitos abertos e dados ao mundo"

Padua (1997) aponta, utilizando diversos exemplos, que sistemas de avaliação formal aplicados aos programas de Educação Ambiental implantados em parques e reservas comprovaram sua eficácia. Para a autora, os ambientes menos estruturados, como é o caso das áreas abertas, por favorecerem o contato direto com o ambiente natural, afetam especialmente o domínio afetivo das pessoas, desde que o trabalho seja direcionado ao aprendizado e à sensibilização. Unindo o domínio afetivo e o cognitivo, as experiências de contato com áreas naturais facilitam mudanças de comportamento nas pessoas e se constituem em importantes instrumentos educativos, sem os quais qualquer iniciativa de proteção e conservação ambiental está fadada ao fracasso (WELLS \& BRANDON, 1992).

As pesquisas sobre a relação entre lazer em áreas naturais e Educação Ambiental são relativamente recentes e vêm crescendo e assumindo uma relevância cada vez maior nas duas últimas décadas. Isso decorre do fato de que há muito tempo o ser humano já se distanciou da natureza, tornando-se necessário e premente um reencontro, no sentido de informá-lo da dinâmica dos processos ecológicos, bem como, conscientizá-lo para que use sua inteligência na guarda dos recursos não renováveis, pois deles depende sua vida. Deve haver uma simbiose do ser humano com a natureza, uma convivência em comum, que permitiria a ele desenvolver suas aptidões materiais e, mormente as espirituais, ao máximo de suas capacidades (DORST, 1973).

A educação acontece em todos os espaços da vida social, de diferentes formas e em diferentes instâncias, a todo o momento, e, sem que se perceba, apreendem-se as relações cotidianas (BRANDÃO, 1997). Considerando essa realidade, o que pensar sobre educação que acontece no tempo livre? Para atingir as finalidades da EA, é preciso haver sempre a consciência de que este é um trabalho educacional completo e que, portanto, devem-se cumprir todas 
as fases do processo, no qual o lazer (sendo o turismo uma de suas manifestações) tem um caráter primordial.

Nos dias atuais, o lazer e a necessidade de viajar são, sobretudo, criados pela sociedade marcada pelo cotidiano. As pessoas viajam porque já não se sentem à vontade onde se encontram, seja nos locais de trabalho, seja onde moram. Sentem necessidade urgente de se desfazer temporariamente do fardo das condições normais de trabalho, de moradia e de transporte, a fim de estar em condições de retomá-las quando regressarem (KRIPPENDORF, 1989). O lazer, como instrumento pedagógico, deveria se melhor considerado pelos meios formais de educação. Segundo Requixa (1980), a educação deve incluir a demonstração da importância do lazer e o aprendizado como estímulo na diversificação de atividades praticadas. Enfatiza, também, que precisamos valorizar o lazer, conhecer as diferentes atividades para variarmos aquelas em que participaremos no nosso tempo liberado das obrigações.

$\mathrm{Na}$ atualidade, as atividades realizadas na natureza vêm de encontro à necessidade do homem moderno de vivenciar momentos de lazer, buscando uma reaproximação com a mesma, na medida em que o crescimento das cidades causou um rompimento desta ligação (BAHIA \& SAMPAIO, 2005).

Muitos educadores, por acreditarem que experiências positivas junto à natureza influenciam a postura do educando frente a ela e ao ambiente, apontam atividades realizadas em áreas verdes como eficientes ferramentas para a EA, pois acrescentam um conjunto de experiências que, gradativa e simultaneamente, vão construindo a formação, a história de vida e os valores dos participantes (PEGORARO, 2007). As idéias de EA exigem tomadas de posicionamento, e isso não pode ser completado apenas com a aquisição de conhecimentos. Para que ela seja efetivada há que existir a reaproximação do ser humano com o meio natural visando a preservação e o estabelecimento de laços entre ambos (SCHWARTZ \& SILVA, 1999).

As evidências da relação entre conhecimento e comportamentos ainda são inconclusivas (MARTIN \& SIMINTRAS, 1995; CHAN, 1999). Enquanto alguns estudos parecem sugerir que um maior nível de conhecimento resulta 
em comportamentos pró-ambiente efetivos (SCHAHN \& HOLZER, 1990), outros autores notam que esta relação é fraca (DISPOTO, 1977).

Apesar de haver evidências de que a afinidade com a natureza surja do interesse por experiências de contato, tais como observar animais, fenômenos do tempo, ou a mudança das estações (LYONS \& BREAKWELL, 1994), Dispoto (1977), Li (1997) e Maloney \& Ward (1973) mostraram que sentimentos sobre o meio ambiente estão substancialmente correlacionados com comportamentos efetivos e que conhecimento não parece ser um antecedente de emoções.

Para McKenzie (2000, apud SOARES, 2004) vivenciar um ambiente no qual a pessoa não está familiarizada causa um estado de dissonância que gera uma ansiedade construtiva diante do risco e do desconhecido. Este estado lembra muito aquilo Piaget classificava como "desequilíbrio" e o que Capra (2002) chama de necessidade de detectar padrões, de conhecer. Hoje sabemos que a cognição se constrói impreterivelmente sob a razão e a emoção. Não há como separá-las, como operá-las de maneira distinta (MATURANA, 2001).

Apesar de haver alguma evidência empírica que a relação entre comportamentos e conhecimentos, ou mesmo conhecimentos e intenções seja inconclusiva, há uma convicção generalizada de que estas dimensões estão correlacionadas positivamente. Isto é, quanto mais os indivíduos souberem acerca dos efeitos provocados no ambiente pelos seus hábitos de consumo e sobre as atuações nos ambientes naturais, maior será a probabilidade de assumirem comportamentos pró-ambiente. De fato, a maioria dos trabalhos de Educação Ambiental é baseada neste pressuposto aparentemente simples que: quanto mais os cidadãos souberem, mais conscientes serão os seus comportamentos. A relação entre conhecimento e comportamento é, assim, extremamente importante.

A afinidade emocional para com a natureza pode ser distinta do interesse cognitivo sobre as suas partes, ou do de interesse em como funciona a flora, a fauna, e a variedade de seus fenômenos e processos naturais. Alguns indivíduos podem ter interesse científico pela natureza sem sentir nenhuma afinidade emocional com ela. A afinidade emocional é motivada pelo contato e 
experiências sensoriais (KALS, SCHUMACHER \& MONTADA, 1999). Os laços emocionais e interesses cognitivos proporcionados por atividades de lazer junto à natureza fazem aumentar o comportamento pró-ambiente (VINING, 1992). Essas atividades, planejadas para despertar o re-encantamento do ser humano pelo meio ambiente, podem promover uma mudança de paradigma social para que critique a ordem econômica, política e cultural, indispensável para uma transformação da consciência e dos comportamentos das pessoas. Só assim a EA se converterá em um processo estratégico com o propósito de formar valores, capazes de uma re-orientação e uma transição para a sustentabilidade.

Finger (1994) demonstrou que as experiências com natureza são poderosas eliciadoras de comportamentos pró-ambiente, mostrando que as elas são ainda mais importantes do que explicações sobre o valor na natureza. Ladislau (1999), ao analisar abordagens de diversos autores, também percebe como positiva a relação entre lazer e meio ambiente, considerando que a natureza é um grande incentivo para o desenvolvimento de atividades que podem apresentar um espaço fecundo para iniciativas que tangem a preservação ambiental.

Num estudo realizado com usuários de áreas recreativas florestais, Nord, Luloff \& Bridger (1998) demonstraram que a freqüência das visitas às áreas de floresta na Pensilvânia e as atividades das recreações são moderadamente associadas com o comportamento pró-ambiente e fracamente associadas com o interesse pelo conhecimento ambiental.

O fato de terem tido uma relação muito agradável com a natureza e marcantes experiências de vivência da solidariedade na infância leva professores de diferentes disciplinas a incluírem em seus trabalhos a EA (VASCONCELLOS, 2000). Isso sugere que as atividades de EA em áreas naturais devem ser fundamentadas em técnicas que proporcionem um experienciar direto, imediato, estimulado pela compreensão do vivido. Ao considerar esses enfoques, percebe-se que diferentes estratégias são utilizadas para que as oportunidades das trilhas sejam aproveitadas para criar consciência, incorporar apreciação e uma nova maneira de pensar ou encarar 
algo, religando as pessoas ao seu ambiente, ajudando-as a descobrir o seu lugar no mundo (VASCONCELLOS, 1997).

A educação ao ar livre é uma prática que utiliza como recursos educativos os desafios encontrados em ambientes naturais e objetiva 0 desenvolvimento de valores e atitudes do ser humano (BARROS, 2000). Para tanto, dimensões educativas têm sido incorporadas a atividades em ambientes naturais como passeios ecológicos, montanhismo, escotismo, entre outras tantas modalidades de lazer junto à natureza, principalmente por intermédio de trilhas de interpretação da natureza em parques naturais. A sensação de "aventura", implícita na maioria dessas práticas, serve de argumento para quebrar a rotina e o tradicional, a fim de transferir valores como: assumir riscos, adaptar ao novo, tomar iniciativa para vida cotidiana. Betrán \& Betrán (2006, p.86) afirmam que "trata-se de fugir temporariamente do âmbito urbano, transgredir a rotina diária, viver emoções extraordinárias, em companhia do grupo de amigos, nas quais a aventura é mais imaginária que real, e de aumentar os níveis de auto-estima".

Neiman \& Rabinovici (2002, p.148-149) atentam para a necessidade de despertar nas experiências com a natureza, "um sentimento de vínculo com o espaço, uma percepção subjetiva de sua beleza". A experiência direta, de acordo com alguns estudiosos da área de EA, está relacionada à interpretação ambiental, principalmente através da sensibilidade. Na visão de Bedim (2005), para conseguir sensibilizar, despertando sentimentos mais íntimos para com a natureza, as atividades de interpretação ambiental basear-se-ão nos estímulos dos cinco sentidos. Assim, as experiências e desejos intelectuais são realmente vivenciados e não verbalizados (CAPRA, 2002).

Cascino (1999, p.276) acredita que "estar em contato com a natureza, para além dos modismos, é necessidade prioritária, exigência consciente da condição humana". O autor faz referência ao fato inegável de que as pessoas têm encontrado no chamado Ecoturismo uma oportunidade de experienciar situações que as aproximam dos comportamentos inatos os quais se refere Lorenz (1965) e os ecólogos-comportamentais (além de outras correntes da 
psicologia ambiental). Por acionar canais inconscientes pouco explorados pelo cotidiano das sociedades contemporâneas, essas situações acabam por provocar sensações de prazer e bem estar.

Quando o ambiente de infância de professores do ensino fundamental integrantes de curso de vivências em áreas naturais é evocado, são mencionados nos depoimentos as nascentes, as águas limpas e os locais onde vivem os animais, associados com sentidos de um ambiente generoso, que propicia o prazer, a contemplação e a aquisição de conhecimento (SOARES, 1998).

A mudança de paradigmas, de uma visão androcêntrica (o homem no centro) e antropocêntrica (o ser humano dominando o meio ambiente) para a adoção de uma ética "ecosófica" em todas as esferas da vida, é urgente e depende de reflexões e ações humanas sobre suas práticas, e da adoção de uma relação dialética entre reflexão - através de pesquisas - e ação - através de suas práticas diárias. O meio ambiente deve ser interpretado como o resultado das Inter-relações entre natureza e sociedade, valorizando-se a sua relação com a qualidade de vida (social, e não apenas natural) numa esfera de amplitude sistêmica. Só assim será possível um grau de compreensão e valorização, que oriente uma definição do modelo de desenvolvimento sustentável e seu nível de envolvimento e compromisso com as atividades realizadas na natureza, com a cultura das populações locais e com uma lógica de lazer crítico e criativo no meio ambiente (BAHIA \& SAMPAIO, 2005).

Não é o simples caminhar por trilhas ou cavernas que fará a EA se concretizar, pois para tal é necessário que se desenvolva uma nova percepção da natureza. Os mecanismos que favorecem a formação de posturas críticas, a predisposição para mudanças e o comprometimento com 0 universo das questões ambientais a partir das experiências positivas decorrentes de relações afetivo-emocionais vivenciadas no contato com a natureza são discutíveis e exigem muita reflexão. Pegoraro (2007, p.23) não acredita que isso ocorra

\footnotetext{
${ }^{5}$ A ética ecosófica busca uma solução num compromisso de equilíbrio entre as três vertentes ecológicas: o meio ambiente, as relações sociais e a subjetividade humana.
} 
de "forma espontânea, linear e emanada diretamente dos eventos em si, exceto em casos particulares, mas da associação com outros mecanismos fomentadores de vivências e de reflexões críticas voltados para a ação, de modo particular as de ordem coletiva".

Leopold (apud BARROS, 2000) sugere que isso pode ser alcançado de três formas: (a) ensinando a arte e a habilidade de ver beleza na natureza; (b) estimulando o sentido natural de contemplação que existe nas pessoas; e (c) ensinando os conceitos teóricos que explicam como a terra e os seres vivos atingiram suas características atuais (evolução) e como eles mantêm sua existência (ecologia).

Uma vez que o modo de organização da sociedade contemporânea, que afasta o cidadão urbano dos seus semelhantes (somos sós, entre milhões) e da natureza, todas as possibilidades de contato, bem como a possibilidade do repensar os hábitos culturalmente adquiridos pelo indivíduo da sociedade brasileira, podem servir como agentes de re-Educação Ambiental. Envolvem o que os especialistas insistem em chamar de reconstrução de "valores", incitando, naturalmente o estabelecimento de procedimentos e atitudes mais equilibradas na relação com o meio natural e sócio-cultural.

Por concordar com Kals, Schumacher \& Montada (1999) que afirmam ainda faltar abordagens descritivas, ao nível do indivíduo, para uma total compreensão do papel do contato com a natureza para a efetivação da Educação Ambiental, este trabalho procura dar uma contribuição empírica nesse sentido.

Pelas suas características (contato com áreas naturais, colaboração entre membros de pequenos grupos no sentido de superarem adversidades comuns, contato físico, companheirismo) o chamado Ecoturismo, dentre outras oportunidades de promoção do contato dirigido, tem se mostrado um poderoso instrumento de resgate dos vínculos do ser humano com a natureza. Além disso, oferece possibilidades de uma discussão sobre os comportamentos culturalmente arraigados e a necessidade de sua transformação sob uma ótica de sustentabilidade. Nas atividades de Ecoturismo pode-se vivenciar a 
natureza tanto a partir do paradigma que supõe que o ser humano faz parte dela (respirar, alimentar-se e deslocar-se pelo mundo nos confirma essa afirmação), como o que considera todas as diferenças existentes entre os seres humanos e os não humanos (reconhecemos em nós diversas características que nos distinguem dos outros animais). Vivenciar ao mesmo tempo esses dois paradigmas supostamente opostos pode ser uma instigante experiência de aprofundamento da compreensão da realidade (MENDONÇA \& NEIMAN, 2003).

Defende-se, aqui, que o desenvolvimento de atividades especiais, que intensifiquem o contato do ser humano com a natureza, pode contribuir para o afloramento de motivações intrínsecas ao ser humano e uma mudança dos hábitos culturais que, canalizadas corretamente, podem formar cidadãos mais conscientes e atuantes na conservação ambiental além de tornarem-se úteis para os educadores ambientais que trabalham em instâncias formais ou informais. Esta hipótese surgiu de um longo processo de vivência e experiências do pesquisador, durante a realização de atividades de Ecoturismo e Educação Ambiental através do contato dirigido de pessoas com a natureza.

Ecoturismo: atividade mercadológica, educativa, ou ambos?

Uma prática instrumental da Educação Ambiental que precisa ser mais bem estudada e compreendida é o Ecoturismo, que, apesar de já ser praticado há mais de cem anos (desde a criação dos primeiros parques nacionais no mundo: Yellowstone e Yosemite), só nos últimos anos do século $X X$ se configurou como um fenômeno crescente e economicamente significativo. As atividades na natureza constituem um conjunto de práticas recreativas que surge nos países desenvolvidos na década de 1970, se desenvolve e se multiplica nos anos de 1980, e se consolida na década de 1990, com o advento de novos hábitos e gostos da sociedade pós-industrial (BETRÁN, 1995). No Brasil, a década de 1980 foi a precursora das atividades físicas realizadas na natureza, alternando práticas mais esportivas e gerais. 
Diversos autores têm publicado trabalhos sobre o tema (CARNEIRO \& KASTENHOLZ, 2005; COSTA \& COSTA, 2005; GOMES, 2003; KINKER, 2005; LEAL-FILHO, 2005; PEDRINI, 2002, 2005, 2006b, 2007; PEDRINI \& TORGANO, 2005, PIRES, 1998; RODRIGUES, 2003; SALVATI, 2003; dentre outros). O segmento é definido como "atividade turística que utiliza, de forma sustentável, o patrimônio natural e cultural, incentiva sua conservação e busca a formação de uma consciência ambientalista, através da interpretação do ambiente, promovendo o bem-estar das populações" (BRASIL-MICT/MMA, 1994), Em diversos encontros nacionais e internacionais sobre o tema tem sido evidente o grau de distorção sobre o que vem a ser Ecoturismo, mas não há como se pensar em outro que não envolva três pontos básicos: planejamento sustentável, Educação Ambiental e inclusão social (RASTEIRO, 2002).

No entanto, apesar de o Ecoturismo ser definido como um promissor campo de atuação para os educadores ambientais, a sua prática no Brasil ainda está longe de atingir este objetivo. As Diretrizes para uma Política Nacional de Ecoturismo prevêem, entre seus objetivos, a promoção e "o aproveitamento do Ecoturismo como veículo de Educação Ambiental para turistas, comunidades locais e empreendedores do setor", mas ainda são raros os profissionais que compreendem esse pressuposto e realizam-no a contento.

O Ecoturismo se apresenta como uma alternativa de se contrapor à lógica do turismo de massa (estandardizado e predatório), e procura cada vez mais defender a proposição de roteiros personalizados, preocupados com 0 mínimo impacto e com grande interesse paisagístico-ecológico (SERRANO, 1997). No entanto, trata-se de um fenômeno complexo e multidisciplinar, onde muitos aspectos devem ser levados em conta a fim de que ele seja um empreendimento bem sucedido para todos os envolvidos (CEBALLOSLASCURÁIN, 1995).

Seabra (2001) aponta que o caráter sócio-desenvolvimentista do Ecoturismo permeia os projetos oficiais e os discursos políticos, sem, contudo, alcançar e envolver as comunidades que habitam as localidades que 0 recebem, "sendo estas tragadas por uma política oficial massificante, travestida 
de auto-sustentável" (SEABRA, 2001, p.9). Serrano (2000) concorda com essa premissa e demonstra preocupações quanto à prática equivocada deste segmento e como o Ecoturismo vem perdendo a capacidade de criticar as formas tradicionais do turismo de massa, "pois passou igualmente a empacotar com 'embalagens recicláveis', é certo, natureza e subjetividade, disponibilizando-as para um consumo rápido e fácil” (SERRANO, 2000, p.16).

Além da falta de articulação e envolvimento de comunidades locais residentes em áreas onde são implantados projetos de Ecoturismo, nota-se uma preocupação crescente quanto aos aspectos relacionados com o "uso" da natureza como "mercadoria" e a conseqüente devastação ambiental. Muitos dos erros cometidos no modelo econômico vivido na sociedade - lucro, ganância, degradação -, estão sendo cometidos no turismo, diminuindo sua credibilidade (MENEZES \& CORIOLANO, 2002).

Apesar de haver um discurso ecológico que legitima a realização dos esportes em cachoeiras, cavernas, trilhas e montanhas, sem muito questionamento, permeando sua prática com nuances românticas e utilizando termos como "harmonização com a natureza", "integração com a natureza" e outros, presencia-se "uma situação que revela que o caráter inofensivo dos mesmos não se mostra sustentável" (BRUHNS, 2000, p.27)

As divergências filosóficas, ideológicas e conceituais sobre o Ecoturismo talvez representem o tópico central a ser equacionado e trabalhado metodologicamente como ponto de partida para o desenho estratégico de programas efetivos de Educação Ambiental. Vários são os autores que, através de seus estudos, demonstram existirem sérios equívocos no que tange às práticas, ao planejamento e às atitudes vivenciadas em atividades realizadas em áreas naturais. Estes vêm buscando refletir e apontar novas perspectivas de uma lógica pautada em possibilidades de superação do lazer "mercadológico" e mal planejado, em direção a uma conscientização ambiental.

A maior dificuldade talvez advenha do fato do Ecoturismo ser uma idéia "guarda-chuva", uma vez que diversas práticas como caminhadas, escaladas, rapel, espeleologia, passeios de bicicleta, cavalgadas, mergulho, passeios de 
barco, vela, vôo livre, balonismo, estudos do meio, safári fotográfico, observação de fauna e de flora, turismo esotérico e turismo rural, são igualmente entendidas como vertentes dessa atividade (SERRANO, 2000). Dentro dessa enorme gama de possibilidades, a EA vem freqüentemente sendo relegada para segundo plano.

Embora os princípios e diretrizes estejam claramente estabelecidos e pareçam conceitualmente compreendidos pelos profissionais da área, na prática, o trabalho de EA carece ainda de uma visão estratégica, que promova seu desenvolvimento em nível nacional. Esta afirmação é especialmente verdadeira quando são analisados os projetos de desenvolvimento em implementação no Brasil e as dificuldades no planejamento e obtenção de resultados referentes aos compromissos de EA. Este problema se torna ainda mais relevante quando o desenvolvimento da atividade turística, discussão emergencial em um país com o potencial do Brasil, exige um novo conceito em ação pragmática em Educação Ambiental (IRVING, 1997).

Neiman (2005) defende que as instituições brasileiras voltadas para a organização e execução das atividades ecoturísticas possuem um caráter estritamente empresarial. Sendo assim, funcionam dentro da lógica do mercado e priorizam os aspectos voltados à prestação de serviços e ao retorno econômico em detrimento das prioridades conservacionistas e educacionais. Desta forma, sem a atuação educadora de todos os profissionais envolvidos com o Ecoturismo, fica mais difícil vislumbrar-se importantes processos de mudança de valores e atitudes. Por ter surgido como um negócio, o setor ecoturístico não se propôs, ainda, a refletir sobre o que faz. Produz viagens e não prioritariamente experiências, nem conhecimento. Só reproduz estratégias de marketing e conceitos administrativos convencionais, aplicados tradicionalmente a outras áreas do chamado mercado turístico (NEIMAN \& MENDONÇA, 2000).

Para Jesus (2003) esse poderoso circuito do marketing transformou aquilo que inicialmente se propunha um modelo alternativo ao trade, envolvendo uma concepção verdadeiramente ecológica, numa forma de turismo 
predatório que, embora esteja embebido de um discurso atrativo, não discrimina ações pautadas efetivamente na sustentabilidade e na preservação do patrimônio natural/cultural, daquelas experiências nas quais a natureza comparece unicamente como alvo e motivação da superação de limites aos aventureiros que a praticam.

No que se refere à sua ligação direta com a Educação Ambiental, muitas ponderações se fazem necessárias. Basta colocar o indivíduo em contato com a natureza para estar educando-o? "Ensinar" a ciência Ecologia numa trilha em um ambiente natural é fazer "Educação Ambiental? A "ponte" de ligação entre os ambientes natural e urbanizado se faz automaticamente durante as atividades de Ecoturismo? Onde se encontra a fronteira entre um negócio lucrativo e uma preocupação realmente transformadora?

Essas são perguntas para as quais o segmento do Ecoturismo ainda não tem respostas, e é no sentido de responder às duas primeiras e indicar caminhos para a resposta à terceira que se realizou este trabalho. 


\section{2 \\ Uma experiência de EA em áreas naturais}

Desde 1991 pôde-se, pela oportunidade de organizar atividades de contato com a natureza, e com elas de acompanhar bem de perto as atitudes dos indivíduos nestas situações, realizar o que se chama observação participante ${ }^{6}$. Esta experiência constitui a base de onde surgiu o projeto desta

${ }^{6}$ A investigação de comportamentos naturais, em ambientes naturais, e em condições naturais, geralmente é realizada de maneira não-reativa, e, portanto sem que os participantes estejam conscientes da realização da investigação. Agem, portanto, com espontaneidade e, desde que posteriormente lhes seja comunicado os dados colhidos e autorizado seu uso pelo pesquisador, ou assegurado o anonimato, as questões éticas, mesmo complexas, estão relativamente atendidas. A observação participante, ligada à tradição da fenomenologia, nesses casos, é o melhor instrumento de coleta de informações. (MARTINS, 1984). Na observação participante a presença imediata do pesquisador permite-lhe investigar e descrever, a partir das percepções dos sujeitos pesquisados, no momento em que ocorrem, os fenômenos presentes, imagens, palavras ou emoções desveladas pelo diálogo entre o sujeito e seu mundo, que inclui outros sujeitos, interpretálos e compreender seu significado para elaborar a essência do mundo, pela intersubjetividade (QUARANTA-GONÇALVES, GUIMARÃES \& SOARES, 2004). Observado-res participantes começam com algumas hipóteses preliminares antes de coletarem qualquer dado, revisando as mesmas à medida que transcorre a pesquisa através da análise de casos negativos, que substitui a análise estatística na observação participante. A análise de casos negativos requer que o pesquisador procure dados que refutem a hipótese. Quando um único caso negativo é encontrado, o observador participante revê a hipótese de forma que esta possa abarcar o caso. Faz-se isso até não haver mais refutações. Portanto, ser sistemático na pesquisa qualitativa significa fazer uma busca completa de casos que possam refutar a hipótese. Esta busca e coleta de dados é prática de rotina; na realidade, geralmente eles requerem que se formulem novas e diferentes questões em cada busca. As mensurações não são padronizadas; os dados não são uniformes e não produzem números que possam ser somados ou cuja média possa ser calculada. Mas o procedimento é sistemático. A análise de casos negativos, com sua revisão e re-testes contínuos de hipóteses, é mais semelhante ao que os experimentadores fazem quando planejam estudos subseqüentes. $O$ 
tese e é nesse sentido que a ela se fará referência: como um substrato relevante que aponta para os aspectos que merecem estudo controlado e aprofundado. Apesar de não ter sido intencionalmente realizada como uma pesquisa planejada, fez surgir as questões principais que aqui são trabalhadas.

Como em Padua (2004), a metodologia utilizada em parte deste trabalho, pressupõe que o pesquisador se coloque incluído em seu ambiente de estudo, relacionando-se com ele ao interpretar os dados coletados. A interpretação do pesquisador bem como suas visões pessoais sobre as temáticas abordadas passam a ter peso relevante na análise dos resultados.

Essa modalidade da pesquisa qualitativa também é conhecida como pesquisa participante ou pesquisa participativa, é "uma modalidade nova de conhecimento coletivo do mundo e das condições de vida de pessoas, grupos e classes populares" (BRANDÃO, 1981, p.9) ou, ainda, uma modalidade alternativa de pesquisa qualitativa que coloca a ciência a serviço da emancipação social, trazendo alguns desafios: o de pesquisar e o de participar, o de investigar e educar, realizando também a articulação entre teoria e prática (DEMO, 1992).

Não se trata, no entanto, exatamente da chamada "pesquisa-ação", descrita por Barbier (1998), pois os sujeitos analisados não participam da construção da situação experimental. Mas, como nesta metodologia, aqui o pesquisador participou de maneira ativa, sendo um membro do grupo observado. As hipóteses deste trabalho surgiram, inicialmente da observação de atividades de grupos em situações nas quais praticavam Ecoturismo de maneira organizada. O pesquisador fazia parte do grupo cumprindo o papel de "guia" ou "condutor" das atividades de campo.

Entre 1991 e 2006, foram realizadas observações participantes, em 181 viagens de Ecoturismo às Unidades de Conservação ou a outros ambientes naturais com grupos organizados. Para efeito de comparação, pode-se

observador participante faz, na realidade, uma série de estudos consecutivos, mas os analisa todos na mesma pesquisa, pois não há regra que diga que ele não pode mudar as hipóteses, ou questões no decorrer da mesma. A técnica requer, efetivamente, que se mudem as questões para abarcar as respostas e observações não previstas que forem surgindo. 
considerar que apenas as 107 que tiveram como destino o Parque Estadual Turístico do Alto Ribeira (PETAR) - Iporanga - SP, foram sistematicamente observadas e tiveram estratégias de trabalho similares.

Para realizar a observação participante, uma pessoa deve ser um membro integralmente participante do grupo em observação, ou basicamente um observador, participando apenas de forma eventual. Os observadores participantes, como os antropólogos, inserem-se freqüentemente numa situação em que não são membros autênticos, mas em que podem ser aceitos como amigos e observadores confiáveis. Este é o caso deste trabalho onde 0 pesquisador, apesar de exercer o papel de "guia" dos grupos, fez parte do mesmo o tempo todo, vivenciando com todos as mesmas experiências ao longo de dois ou três dias.

Durante 16 anos e após cada uma das 107 viagens organizadas e realizadas ao PETAR, com grupos de participantes de atividades dirigidas, as ocorrências eram discutidas por uma equipe de profissionais e os procedimentos refeitos para novas experimentações, até que se chegasse a uma estratégia de trabalho que, acredita-se, tem grande influência no desenvolvimento de comportamentos pró-ambiente dos participantes das viagens.

Local das atividades de Ecoturismo analisadas

O local onde foram realizadas as atividades relacionadas aos estudos 3 e 4 (ver adiante) deste trabalho foi o Parque Estadual Turístico do Alto Ribeira (PETAR), em lporanga - SP.

Localizado na Região do vale do rio Ribeira de Iguape, a $350 \mathrm{~km}$ da cidade de São Paulo (Figura 1), o PETAR, criado em 1958, e atualmente é administrado pela Fundação Florestal com a colaboração das Prefeituras Municipais de Iporanga e Apiaí, e da Sociedade Brasileira de Espeleologia SBE.

A região é uma das últimas áreas de Mata Atlântica preservadas do Estado e considerada com a maior concentração de cavernas do Brasil, além de cachoeiras, rios, montanhas, vales, fauna e flora ameaçadas de extinção. 

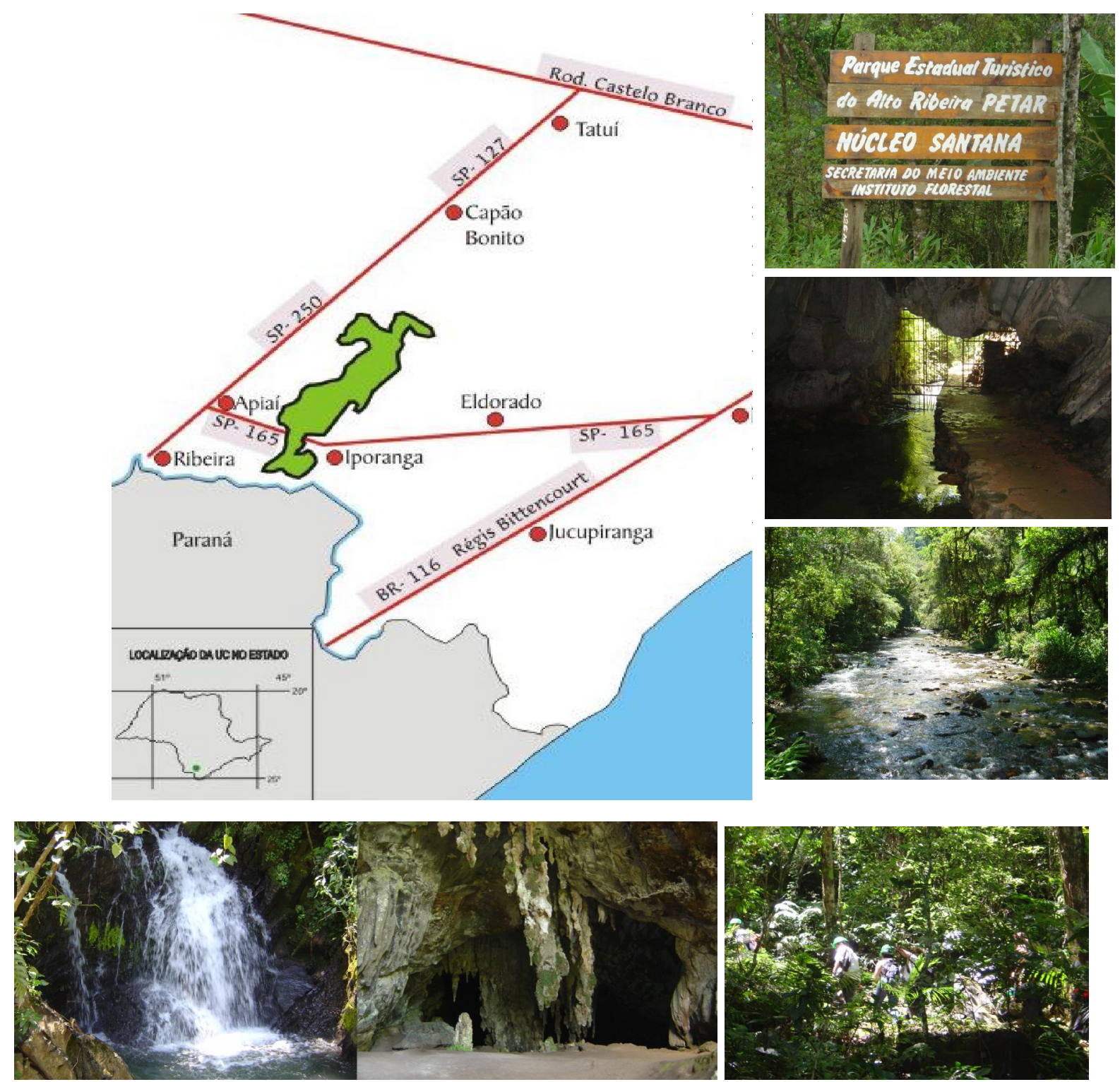

Figura 1: Mapa esquemático de localização (fonte: Instituto florestal www.iflorestal.sp.gov.br/ unidades_conservacao) e rios, cachoeiras, mata, trilhas e cavernas do PETAR - Parque Estadual Turístico do Alto Ribeira (Fotos: Zysman Neiman/out-2005).

Nas suas incontáveis cavernas impressiona a enorme variedade de formações, ou espeleotemas (estalactites, estalagmites, cortinas, colunas etc.), que causam a admiração dos visitantes e freqüentemente intrigam os pesquisadores (RABINOVICI, 2002). A Mata Atlântica, presente nos seus mais de 36.000 ha, e a maioria das cavernas do PETAR, têm um atrativo especial: o fato de estarem pouco alteradas e se apresentarem "ao natural" a seus visitantes (Figura 2). 

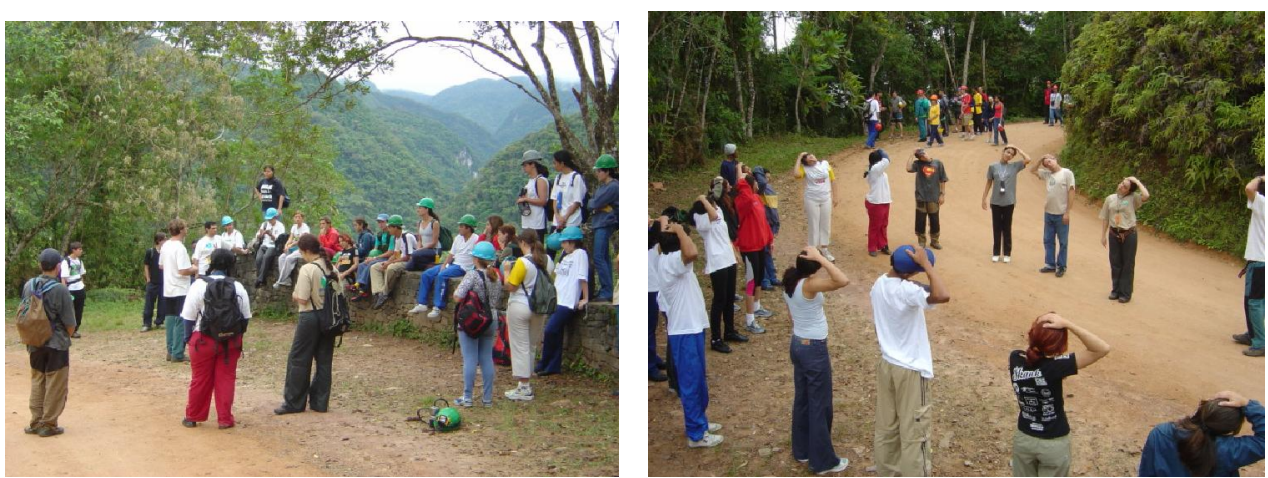

Figura 2: Grupo iniciando visitação no Parque Estadual Turístico do Alto Ribeira - PETAR (Fotos: Zysman Neiman/jun-2006)

Por serem interpretados pelo visitante como ambientes "intocados", a Mata Atlântica e as cavernas do PETAR têm sido muito procurados como destino do Ecoturismo e freqüentam o imaginário dos cidadãos urbanos dos grandes centros emissores (Grande São Paulo, principalmente, e Curitiba). Esse aspecto simbólico é, inclusive, muito explorado pelo marketing praticado pelas agências de Ecoturismo que trabalham na região reforça esse imaginário.

Além dos grupos de espeleologia que desde o final dos anos de 1950 passaram a explorar e mapear as cavernas houve pouca visitação ao PETAR, sendo que até o início dos anos de 1980, ocorria apenas uma procura restrita a grupos de excursionistas, em sua maioria universitários. A partir daí, várias agências de turismo ecológico e estudos do meio passaram a fazer uso mais regular do Parque. Paralelamente ao aumento do fluxo turístico, devido principalmente ao aumento desenfreado do número de agências e pessoas que organizam grupos de viagens, houve uma ampla divulgação na mídia. Esta superexposição acabou acarretando uma procura maior ainda por parte do público espontâneo, que vem em busca tanto das belezas das cavernas como da riqueza da grande área de Mata Atlântica preservada.

Em contrapartida, o Parque, como a quase totalidade das Unidades de Conservação brasileiras, luta contra a falta de recursos humanos e financeiros. Dos Núcleos do Parque (Santana, Ouro Grosso e Caboclos) o mais intensamente procurado e o que mais sofre com esta situação é o Núcleo 
Santana. Sua principal atração é caverna de Santana, considerada uma das mais belas e ornamentada do Brasil. Atualmente enfrenta-se uma superlotação em finais de semana e feriados, provocando um impacto em trilhas e cavernas e comprometendo a qualidade dos serviços de Ecoturismo e Educação Ambiental.

\section{Atividades desenvolvidas e observação participante}

Ao longo dos anos, através da observação participante de atividades de Ecoturismo, procurou-se detectar e compreender quais os comportamentos humanos que se manifestam durante o desenvolvimento dessas atividades. Foram analisados, também, quais processos potencializam a transformação dos comportamentos culturalmente adquiridos, no sentido de contribuir com a sedimentação da importância da Educação Ambiental em Unidades de Conservação.

Nas 107 viagens com grupos ao PETAR nas quais a observação participante foi seguida em seus pressupostos, realizadas entre 1991 e 2006, participaram cerca de 3.000 pessoas, sendo a maioria da faixa etária entre $15 \mathrm{a}$ 30 anos.

O objetivo educacional do trabalho realizado nestas viagens é uma melhor compreensão do valor da conservação da natureza e da diversidade sócio-cultural, priorizando a sensibilização do indivíduo quanto à importância do seu papel na construção de um mundo diferente, tanto na relação sociedade $x$ natureza quanto à dos indivíduos entre si. O Ecoturismo é, portanto, entendido como ferramenta para a Educação Ambiental.

Visando romper com a análise fragmentada da realidade, em todas as viagens procurou-se promover a integração entre aspectos psicológicos, biológicos, históricos, geográficos e sociais, propiciando um conhecimento mais aprofundado da realidade, e não da teoria referente a cada uma das áreas do 
saber. Para a busca da interdisciplinaridade entre os conteúdos trabalhados, utilizou-se a Interpretação Ambiental ${ }^{7}$, como principal estratégia educacional.

Assim, ao longo da viagem, os guias acompanhantes apresentavam as principais características ambientais e culturais presentes no PETAR e no seu entorno. A informação não era negada, mas nascia a partir do interesse do grupo e respeitava a bagagem anterior que cada um demonstrava, além de ser apresentada de forma agradável. Ou seja, as intervenções eram amenas, pertinentes e respeitosas com as características sócio-culturais de cada grupo.

Vale lembrar, no entanto, que nas viagens realizadas, os conteúdos conceituais apresentados por essa técnica foram tendo peso cada vez mais inferior ao trabalho com os conteúdos valorativos e procedimentais. $\mathrm{O}$ procedimento sistemático da observação participante foi modificando o roteiro, as atividades e o próprio objetivo das viagens a partir da refutação de hipóteses e sua substituição por outras.

As primeiras viagens tinham um foco mais centrado na transmissão dos conteúdos relativos à dinâmica ambiental do Parque. Isso porque, no início dos anos de 1990, a formação acadêmica dos profissionais que acompanhavam a viagem, aliada a diminuta experiência coletiva na realização das mesmas, fazia com que os viajantes fossem submetidos a uma excessiva valorização de conhecimentos científicos. Coerentemente à formação que tiveram, os guias da equipe se reuniam para discutir os objetivos interdisciplinares a serem alcançados e elaboravam o melhor roteiro de atividades para atingi-los. Uma série de reuniões foi necessária, para que esta equipe de educadores encontrasse os pontos tangenciais dos conteúdos conceituais que poderiam ser "amarrados" na viagem a ser desenvolvida. Nesta fase, inclusive, eram preparados materiais pedagógicos de apoio e roteiros de observação em

\footnotetext{
${ }^{7}$ Pagani et. al. (1996, p.154) define a interpretação ambiental como "uma técnica didática, flexível e moldável às mais variadas situações, que busca esclarecer os fenômenos da natureza para determinado público-alvo, em linguagem adequada e acessível, utilizando os mais variados meios auxiliares para tal". Por conciliar a educação com atividades lúdicas e turismo, a interpretação ambiental é um poderoso instrumento que pode agregar aprendizagem e sensibilização nos visitantes, transformando seus valores aos lugares percorridos.
} 
campo, com perguntas, orientações e proposições de amostras a serem recolhidos e/ou observados pelos participantes.

Cada parada para a realização de interpretação ambiental estava ligada a um conceito a ser transmitido. A hipótese que se acredita verdadeira era a de que o despertar para a consciência ambiental se daria através do aumento dos conhecimentos sobre a dinâmica de funcionamento dos ecossistemas e a compreensão dos problemas ambientais que eles enfrentavam.

A partir da proposição de um trabalho conceitual sobre alguns temas escolhidos, as viagens procuravam estimular os participantes à observação, à pesquisa e à interação com os elementos naturais e sócio-culturais do PETAR ambicionando, ainda, colocá-los em contato com diferentes realidades sociais e ambientais, o que se acreditava, era suficiente para levantar-se questões de ética, cidadania e respeito à diversidade, valores importantes que se espera incutir num cidadão ponderado e socialmente participante.

O "teste da eficiência" desse procedimento sempre foi a avaliação das vivências através de conversas informais, pois inevitavelmente formava-se um importante vínculo entre os guias e o grupo, e de uma discussão ao final das atividades (fechamento) com todos, com registro dos discursos e comportamentos exibidos. Este fechamento era, para o grupo, o momento fundamental de racionalização de tudo que foi sentido durante a viagem, mas ainda não verbalizado, e para os pesquisadores, o momento de testar as hipóteses. Com um mosaico de relatos e impressões, os participantes das viagens montavam um painel dos fatos mais marcantes para cada indivíduo durante estes dias de intenso contato com a natureza.

Uma vez que os discursos emitidos pelos participantes da viagem eram distantes daqueles ambicionados quando da elaboração do roteiro de atividades (muito teóricos, "frios", memorizados e burocráticos), e, pior, não se repetiam grupo após grupo (o que permitiria supor que a hipótese era verdadeira), os procedimentos foram, ao longo desse período de avaliações (1991-2006), sendo alterados. 
Para Mendonça \& Neiman (2003), uma visita às áreas naturais organizada com esses pressupostos sempre está atrelada à lógica do racionalismo, do empirismo e do positivismo. Reproduz toda valorização dos conceitos e da visão objetiva dos fatos. Sujeito e objeto estão muito claramente separados e o conhecimento está sendo produzido a partir da percepção sensorial compreendida à luz das capacidades cognitivas. Essa constatação aponta para a necessidade de promover mudanças nos "estudos do meio" de modo a sintonizá-los às novas formas de conviver, relacionar-se com a realidade observada e sentida, construir e reconstruir outras compreensões, produzir e distribuir sensações, informações e conhecimentos. É preciso fugir do conceito enganoso de que o meio estudado é a extensão da sala de aula.

Mesmo que se procure trabalhar o discurso da responsabilidade ecológica e as éticas morais para com a natureza, as experiências diretas nas quais todos os cinco sentidos sejam utilizados para promover uma afinidade emocional com ela parecem ser mais eficientes para as mudanças de atitudes (KALS, SCHUMACHER \& MONTADA, 1999). Por aumentar essa compreensão, aos poucos, a ênfase na transmissão de conceitos (que inclusive eram realizados através da distribuição de textos e cadernos de atividades aos participantes) foi sendo substituída por um trabalho centrado nas vivências sensoriais e emocionais na natureza, ou seja, passaram a ter o objetivo de instrumentalizar menos para sensibilizar mais.

Uma pesquisa de Fazio \& Zanna (1981, apud UZZELL, 2004, p.367368), inclusive, mostrou que a experiência direta com o objeto da atitude conduz a atitudes mais fortes, quando comparadas a experiências indiretas. A razão instrumental é muito eficiente para resolver questões técnicas, mas ela está longe de ser suficiente para resolver problemas humanos. Os problemas ambientais são essencialmente humanos, e só serão superados se incluirmos uma nova maneira de abordá-los. A expressão "viagem sem destino" incomoda um pouco ao cartesiano, com sua visão positivista, pois estão pouco dispostos e enfrentar o risco das surpresas (MENDONÇA \& NEIMAN, 2003). 
Desta forma, devido ao descarte de hipóteses previsto na observação participante, chegou-se a um roteiro de atividades capaz de produzir, nos fechamentos da viagem, discursos mais similares e recorrentes, estágio onde se pressupõe que a Educação Ambiental tenha sido efetivada, ou pelo menos que haja uma previsibilidade de valores e atitudes declarados.

Passando, ao longo dos anos, pelos estágios intermediários que foram constantemente sendo modificados conforme as avaliações e a observação participante sugeriam, chegou-se a formulação de atividades que objetivaram a transformação da visão que coloca o saber como algo distante, aproximando o indivíduo da realidade que está sendo visitada, buscando uma interação entre a sensibilidade e a razão.

Segundo Mendonça (2000), devido ao seu uso indiscriminado, as áreas naturais, que hoje se encontram preservadas, por serem minoria ante as áreas ocupadas por atividades humanas, devem abrigar atividades que valorizem o relacionamento dos participantes com os elementos naturais, de modo a criar neles um compromisso com os lugares e culturas visitados.

A aposta metodológica foi o potencial transformador das vivências das pessoas entre si e com o meio, através do contato dirigido e intensificado com a natureza. Foram criadas estratégias que promoveram experiências pessoais e coletivas através da exposição a limites pessoais, medos, inseguranças, sucessos e a da atuação em equipe (pressupondo confiança, solidariedade e afeto), cuidando-se para que as atividades não perdessem o caráter lúdico, normalmente associado ao Ecoturismo. Valorizou-se o olhar menos analítico e mais subjetivo sobre a realidade.

A percepção da paisagem é derivada de fatores educacionais e culturais e fatores emotivos, afetivos e sensitivos, sendo estes últimos oriundos das relações que o observador mantêm com o ambiente. A interpretação da paisagem está sob controle direto da maneira como cada um enxerga o mundo a partir de sua história pessoal, experiências prévias e expectativas, mas a experiência vivida pode ajudar a construir um novo conhecimento (FERREIRA \& COUTINHO, 2000). 
Assim, os participantes foram levados a trabalhar a sensibilização, a emotividade e a intuição. As atividades não estavam ligadas ao raciocínio, mas sim a aspectos emocionais. O conteúdo formal só era transmitido à medida que se prestava a aumentar o deslumbramento diante do local, como, por exemplo, saber que aquele vale imenso que se avista do alto foi cavado pelas águas do pequeno riacho lá embaixo, ou que as estalactites que se observam nas cavernas levam o tempo de uma vida humana para crescer apenas uns poucos centímetros (FARIA \& GARCIA, 2002).

Quaranta-Gonçalves, Guimarães \& Soares (2006) recomendam a realização de atividades de sensibilização no percurso de uma trilha, tais como pedir para que as pessoas, em silêncio e de olhos fechados, prestem atenção aos sons, odores, vento e outras sensações, além de valorizar a orientação das pessoas por outros sentidos que não a visão, como, por exemplo, o uso do tato para melhor se perceber detalhes e características de plantas. Apesar da pequena quantidade de estudos empíricos que forneçam fundação para programas similares, Bolsho et. al. (1990) apontam que é possível promover o comportamento pró-ambiente através de experiências diretas com a natureza que utilizem todos os sentidos.

A educação, a percepção e o lúdico devem ser utilizados para possibilitar a expansão de uma consciência conservacionista através, sempre, do envolvimento afetivo das pessoas com a natureza e as culturas locais, numa tentativa de apropriação deste novo território como sendo o seu. A transformação de espaços em lugares, como propõe Tuan (1983) é estimulada e o PETAR tem atrativos facilitadores que auxiliam essa transformação.

De modo a propiciar aos participantes vivências com situações que envolvem medo, fascínio, insegurança e limitação com relação às obras da natureza, os participantes foram conduzidos por trilhas e cavernas onde ficaram expostos a "obstáculos" com os quais não estão acostumados em seu cotidiano. O próprio ambiente das cavernas se Ihes apresenta como "estranho", "desconhecido" e, em alguns casos, até mesmo "inexpugnável". O mesmo vale 
dizer para a floresta, que para a maioria dos participantes das viagens, também carrega uma grande quantidade de significados misteriosos e desafiadores.

Há um grande potencial de indução ao estado contemplativo pela imagem paisagística e a magia associada aos momentos de intensa interatividade com o meio, elementos que estão associados ao fenômeno perceptivo do ambiente, e que geram lembranças e a nostalgia do significado do seu vislumbre (MARIN, OLIVEIRA \& COMAR, 2003).

Assim, ao longo de dois dias foram convidados a atravessar galerias estreitas nas cavernas, percorrer trechos de rios subterrâneos com água "até o pescoço", deitar-se sobre o chão da caverna para realizar atividade de relaxamento, equilibrar-se sobre pedras escorregadias de desmoronamentos, andar em silêncio pela mata, comer comida feita no fogão à lenha, ouvir histórias da comunidade, brincar com os colegas e ajudá-los nas suas dificuldades, suportar diferenças e respeitar opiniões, ajustar ritmos, e abrir mão de "conforto supérfluo", substituindo-o pela hospitalidade das comunidades locais (Figura 3 ).
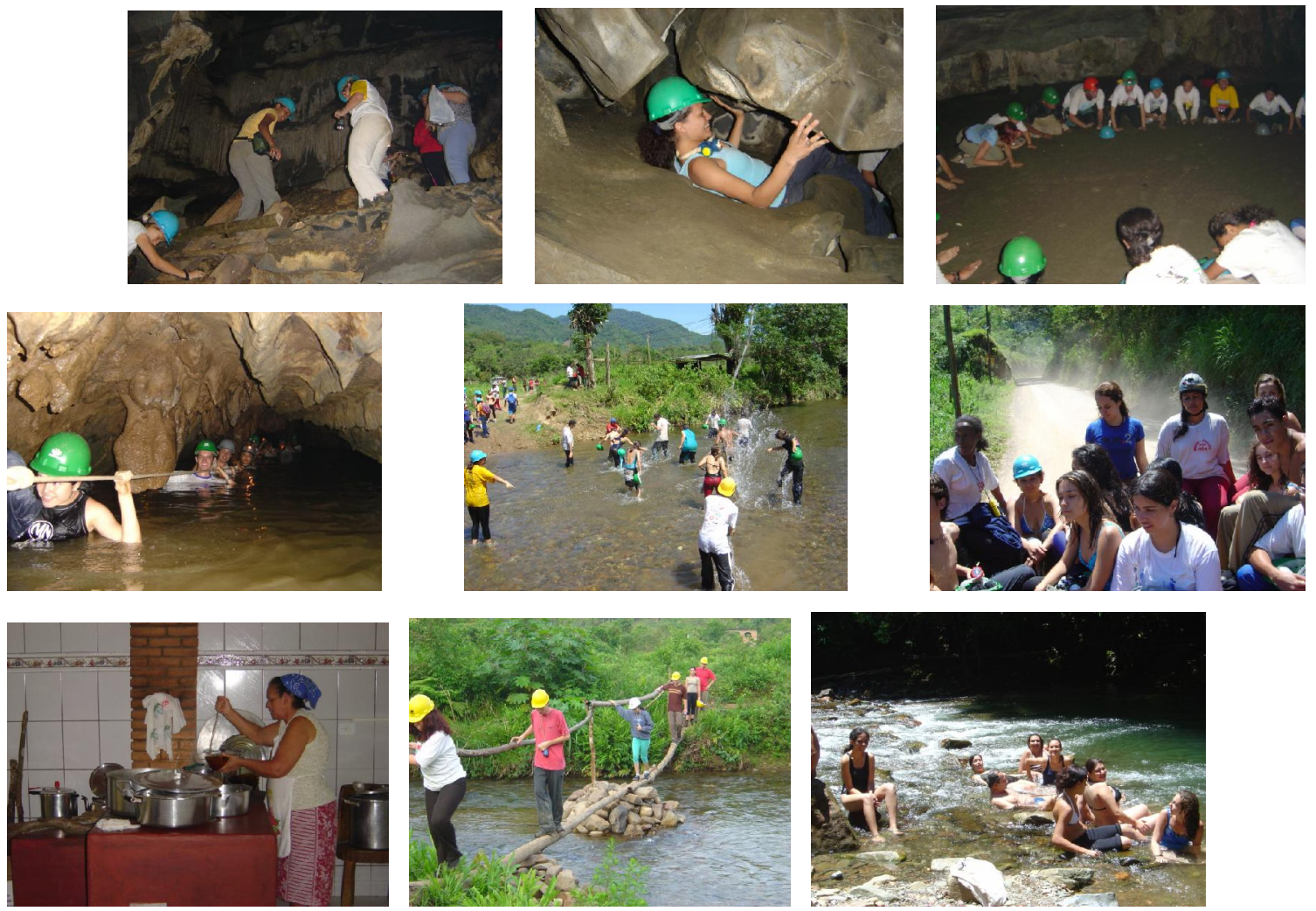

Figura 3: Diversas atividades realizadas com os participantes de viagens ao Parque Estadual Turístico do Alto Ribeira - PETAR (Fotos: Zysman Neiman/jun-2006) 
Quanto maiores são as diferenças existentes entre o ambiente visitado e o do cotidiano do indivíduo, maiores são os contrastes encontrados e, portanto, mais instigantes os questionamentos. A retirada do cotidiano propicia ao cidadão a possibilidade de, no contato direto com novas realidades, repensar 0 seu próprio modo de vida, analisando a sua qualidade e re-elaborando seus valores e conceitos.

Quando estão em contato com a Natureza, os muitos caminhantes enfrentam diferentes níveis de dificuldade, surpreendem-se com diversos fenômenos, compartilham sentimentos semelhantes. Confirmam sua própria existência pela percepção simultânea e comunicação com o outro. Os sentimentos de complementaridade, as posturas de solidariedade costumam brotar espontaneamente nessas excursões. Há um enorme prazer em poder ajudar o outro, ajudar a carregar, expressar o que sabe e o que sente, dar a mão para ajudar a subir ou a descer, compartilhar as mesmas emoções, reconhecer a alegria de estar junto àquela companhia (MENDONÇA \& NEIMAN, 2003).

Os guias que acompanham as atividades foram orientados para ajudar o mínimo possível a superação das dificuldades individuais, proporcionando assim, indiretamente, o surgimento do espírito cooperativo dos demais participantes, numa clara tentativa de estimular o exercício do altruísmo. Compartilhar a experiência com um outro pode funcionar como um amplificador do impacto da emoção da estada. A comunicação e a transferência de emoções sociais positivas com o ambiente natural podem contribuir para emergência de uma maior afinidade emocional (KALS, SCHUMACHER \& MONTADA, 1999). Por isso, nas caminhadas por trilhas e cavernas, estimulou-se ao máximo a cordialidade e solidariedade entre o grupo.

Todas as informações foram passadas aos poucos, na medida em que a caverna apresentava seus mistérios, despertando, invariavelmente, a curiosidade do viajante. Tomando o cuidado de não priorizar o conteúdo, nem valorizar apenas a quantidade de informações transmitidas, foram abordados também conceitos sobre o porquê da diversidade da Mata Atlântica, suas 
espécies ameaçadas de extinção, qual a importância da mata para as cavernas, o que significa a área natural do PETAR para a comunidade local etc.

Se, na ansiedade de conhecer o maior número de cavernas possível num curto espaço de tempo, fosse repetido o ritmo urbano e frenético, estar-seia na verdade, desperdiçando o precioso tempo de contato com a natureza. Para não correr este risco, foi planejada uma seqüência de atividades, dosada de modo que cada um teve tempo para "construir" sua própria caverna. Isto significa ter tempo para observar e contemplar.

Após intenso trabalho de estudo, realizado ao longo dos anos desde 1991, sobre sua eficiência e garantia de segurança, algumas atividades foram especialmente criadas, planejadas e executadas para mexer com os sentidos, os sentimentos e as emoções. São intervenções que procuram intensificar as percepções que os indivíduos já vem experimentando ao longo da visita, uma vez que o simples ato de conhecer não goza de força suficiente para transformar, talvez com raras exceções.

Na primeira caverna visitada, ainda a escuridão e a novidade trazem de início a insegurança. Pouco a pouco, porém, os fachos de luz das lanternas começam a passear e os olhos começam a observar a beleza que se apresenta por todos os lados. De qualquer ângulo que se ilumine, do chão ao teto, surgem detalhes a serem investigados. As inúmeras formas dos espeleotemas, as passagens estreitas ou o alto teto de um salão da caverna, tudo desperta a vontade de explorar e conhecer. Com a curiosidade já aguçada, as perguntas vêm de maneira natural, antes de qualquer explanação. O grupo é convidado então a tentar imaginar como se deram os processos geológicos que geraram aquelas formas. Já bem distantes da luz da entrada, experimentam, em seguida, a escuridão pela primeira vez. Como a maioria das pessoas nunca teve a oportunidade de estar imersa num escuro tão intenso como o de uma caverna, o grupo se acomoda pelo chão e apaga-se a luz. A voz do guia mantém ainda algum contato com a realidade anterior, e o grupo é levado a imaginar, por exemplo, como seria a vida dos pequenos animais do fundo da caverna e como encontrava esta caverna antes de sua ruidosa e iluminada 
chegada. Um trabalho delicado que exige certa dose de sensibilidade é fazer com que pessoas, às vezes extremamente urbanas, se sintam à vontade num ambiente úmido, escuro e totalmente desconhecido. Discute-se, ainda com a luz apagada, se houve algum tipo de desconforto em relação à escuridão e porque. O que significa o medo? (FARIA \& GARCIA, 2002).

Dá-se continuidade às visitas a outras duas cavernas (Morro Preto e Couto), onde um trabalho de percepção e relaxamento sempre é realizado com um pequeno número de pessoas por grupo (de dez a doze, no máximo). Deste modo, os participantes criam um vínculo maior entre eles e com a própria caverna. Sem nunca estimular um clima de competição dentro do grupo, os obstáculos que se interpõem, pedras ou desníveis, são superados em conjunto.

O sentimento de perplexidade diante das riquezas das cavernas do PETAR acompanha a todos. Ao se apagar a luz mais uma vez, agora na Caverna do Morro Preto, imediatamente os outros sentidos são despertados. Aguça-se o olfato, ouve-se uma gota caindo ao longe, percebe-se a alta umidade do ar. É hora dos participantes tomarem contato com seus medos mais primais. Não aqueles que fazem parte de seu cotidiano e são fabricados pelo ritmo urbano (ser assaltado, perder o emprego, chegar atrasado), mas o medo da desorientação, de se estar sozinho sem o grupo, ou apenas um medo inexplicável. Percebem então, como diante do nada ou da escuridão completa de uma caverna são capazes de abrir espaço para reflexão. É nesse clima de envolvimento que os guias conduzem uma atividade de relaxamento, com utilização de músicas e narração de histórias.

Intercalando as cavernas, são percorridas trilhas na Mata Atlântica, e à beira das águas transparentes do Rio Bethary, são feitas as pausas para o lanche. Um banho de cachoeira ajuda os participantes a recuperem as forças para continuar a viagem trajetória.

$\mathrm{Na}$ caverna seguinte (Couto) é proposta uma atividade de se andar alguns passos no escuro. O local escolhido previamente é plano e sem desníveis, onde há uma parede lateral que serve de guia. O trajeto é simples e quase sem obstáculos, mas cada metro vencido parece quilômetros, diante da 
dificuldade de locomoção sem o auxílio da visão. Aqui, os laços de solidariedade entre o grupo são postos à prova mais do que em qualquer momento. A situação exige que as pessoas se auxiliem, dêem as mãos e tentem explicar o caminho umas as outras.

No último dia de visita ao PETAR, o grupo é convidado a atravessar a caverna Alambari de Baixo, que oferece as maiores dificuldades em termos de obstáculos. No entanto, com a união adquirida pelo grupo no dia anterior, a tarefa torna-se bem mais simples. Num amplo salão da caverna, antes de saída, é realizada, mais uma vez no escuro total, uma atividade de uso do tato para percepção de folhas e pedras levadas pelo guia. Para finalizar faz-se também uma última pausa para uma despedida simbólica da caverna, onde cada participante é convidado a refletir sobre o significado para ele daquelas vivências intensas e diretas com a natureza. No trecho final, ainda dentro da caverna, o grupo acompanha o leito de um rio, com a água aproximadamente na altura do peito, as vezes um pouco mais funda, dependendo das condições de chuva da época. O teto e as paredes da caverna vão se fechando em forma de túnel até que se alcança sua saída, estreita e encravada metros acima. Em relatos espontâneos, muitos viajantes já descreveram esta hora como sendo, para eles, um "renascimento".

Resumidamente, pode-se dizer que apagar a luz nas cavernas e permanecer em silêncio por alguns minutos, caminhar por alguns metros totalmente no escuro, tomar banho de rios e cachoeiras, tentar ouvir pássaros que cantam na mata, são exemplos das atividades que foram realizadas nessas viagens.

"Ao considerarmos estes enfoques, estas atividades tornam-se uma experiência de possibilidades de movimentos externos e internos, de explorações objetivas e subjetivas, de sensações e experiências cognitivas e afetivas suficientemente capazes de proporcionar a busca de novas situações onde respeito à Natureza, a si e ao outro, com a observância de valores relativos à cooperação, companheirismo, solicitudes, limitações e especialidades, disposição proativa, convivência com as diferenças pessoais, constituem-se em marcas e 
exercícios constantes durante todas as séries de atividades ao longo de seu percurso." (GUIMARÃES, 2006, p.6)

Em todas as cavernas as atividades realizadas treinaram a percepção e fizeram as pessoas, aos poucos, sentirem-se parte daquele ambiente a princípio tão estranho. Não foi raro ficarem tão à vontade a ponto de dormirem durante a atividade de relaxamento feita no salão da caverna Morro Preto, esquecendo o frio, o cansaço e a insegurança.

Enfim, o intuito das viagens foi não se limitar apenas a admirar as belas paisagens da mata e os cenários exóticos de dentro da caverna. A intenção foi gerar desconforto, não no sentido físico (que é inevitável), mas somente no de provocar reflexões mais profundas sobre o modo de vida de cada um.

As viagens, normalmente, tiveram a duração de dois dias onde, através de uma imersão no ambiente visitado, os participantes puderam conhecer pessoas e lugares novos e inusitados. Foram estimulados a perceber, a cada momento, todas as possibilidades de enriquecimento pessoal desse contato direto com culturas tão díspares. Na verdade o que se objetivou foi a formação de um cidadão capaz de perceber que existem muitos modos diferentes de se viver e que o seu não é obrigatoriamente a melhor, mas apenas mais um.

Após dois dias de contato direto com as formações naturais do PETAR, os grupos foram levados para conhecer, no Parque Estadual de Jacupiranga SP, a Caverna do Diabo, transformada pelo ser humano, iluminada e com escadas de cimento construídas para facilitar o turismo de massa. Essa é uma etapa crucial no processo de sensibilização e sua inclusão no roteiro é mais um dos resultados obtidos pelo processo da observação participante. Constatou-se ao longo do tempo e após diversas experimentações de atividades, que esta caverna tinha uma força muito grande em gerar reflexões, pois, ao se deparem com as alterações e provocados a discutir sobre o que sentiram ali em comparação com o que sentiram nas cavernas "selvagens" do PETAR, invariavelmente eles se mostraram indignados. Argumentam, diante das 
transformações, que aquilo "não é mais uma caverna", é outro espaço (Figura 4)
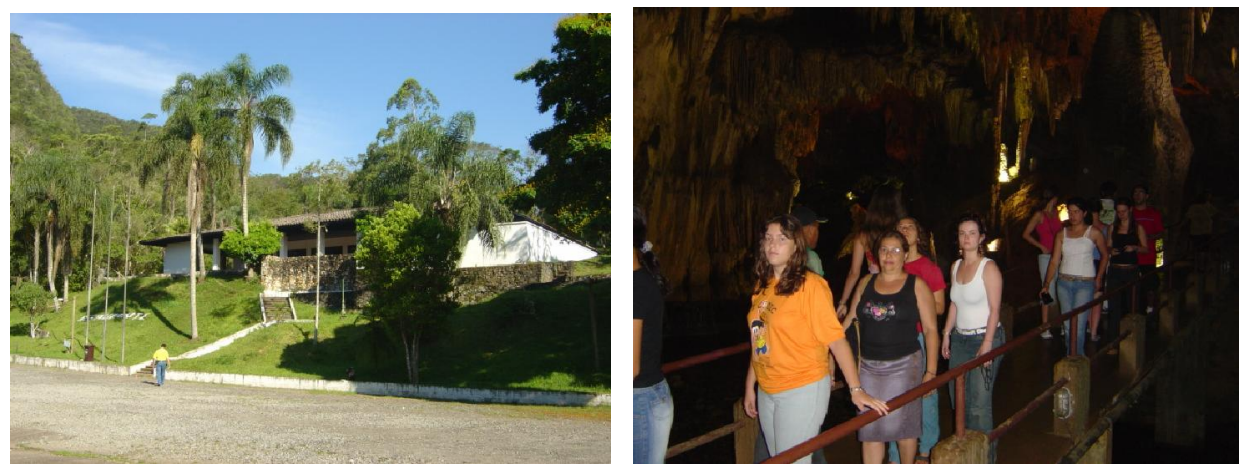

Figura 4: Parque Estadual do J acupiranga e visitantes nas passarelas iluminadas da Caverna do Diabo (Fotos: Zysman Neiman/out-2005).

Aproveitando dessa indignação, realizaram-se, ainda no interior da Caverna do Diabo, discussões a respeito da transformação que o ser humano provoca no meio ambiente, do distanciamento que existe entre eles e a natureza a partir do que sentiram de diferente entre as duas experiências. A proximidade que vivenciaram as cavernas do PETAR, (onde rastejaram, se molharam, se sujaram, sentiram), na Caverna do Diabo se torna impossível: o corrimão das passarelas delimita claramente o espaço "domesticado" e, portanto, humanizado, do espaço "agressivo" e "perigoso" (mesmo que fascinante) da natureza bruta. Esse afloramento do sentimento de revolta diante da "domesticação" da caverna Ihes deu consciência do que toda humanidade tem vivenciado: quebrou-se o vínculo ser humano com a natureza. Essa dicotomia Ihes faz mal e contribui com a geração dos problemas ambientais, uma vez que, ao não se conhecer, não se estar próximo (aquele não é mais seu território), não se ter apego, o relacionamento afetivo com a natureza e pelo ambiente em que se vive fica comprometido. Na verdade não havendo uma proximidade, não há preocupação em se preservar. A Caverna do Diabo serviu para eles como "metáfora" do desequilíbrio existente na relação do ser humano com o ambiente.

Um estudo realizado por Fazio \& Zanna (1981, apud UZZELL, 2004) descobriu que mesmo uma Educação Ambiental que aposte na realização de 
atividades práticas diretas do tipo "mão-na-massa" para trabalhar conhecimentos, não produz mudanças duradouras nas atitudes ou valores ambientais das crianças. As crianças, neste estudo, foram transportadas, durante uma semana, de um ambiente urbano muito familiar no qual elas viviam, para um meio ambiente rural muito incomum, no qual elas experenciaram ciência. Mas os resultados constatam que, após 6 semanas, as crianças estavam menos preocupadas com o meio ambiente do que antes da intervenção da Educação Ambiental, pois o mundo que pensavam como sendo real e familiar tornou-se abstrato e não-familiar e elas não podiam relacionar o conteúdo científico de suas lições ao mundo social que normalmente habitam.

Para evitar o mesmo erro, e com o objetivo de se realizar uma transposição do debate realizado na Caverna do Diabo com o mundo "real" onde vivem os participantes da viagem, foram apresentadas algumas possibilidades de ocupação mais racional desses espaços e do ambiente.

Tais discussões serviram como "avaliação" da metodologia aplicada, uma vez que se espera depoimentos que revelem as transformações de comportamentos eliciadas. Após todos esses 16 anos de re-elaboração das atividades desenvolvidas através da metodologia da observação participante, chegou-se ao ponto no qual cada testemunho e depoimento pode ser "previsto", em sua essência, antes mesmo de ser emitido. A hipótese do experimento (observação participante) não pode ser mais descartada: há um alto grau de envolvimento dos participantes com a viagem, que transparece nas declarações da grande ligação afetiva com o lugar visitado. O contato dirigido com a natureza fez aflorar alguns sentimentos encobertos pela cultura.

"A reflexão é o momento em que o ser humano procura o entendimento das suas percepções, questiona e dá forma aos significados do percebido e configura a sua relação com o mundo. É nesse contexto que ganham relevância as informações sobre a visão sistêmica onde se inserem as imagens constituídas. No instante em que se questiona sobre o seu lugar na paisagem percebida é que torna-se possível a avaliação de sua ações nesse sistema. Mas, nesse instante, já não trata mais puramente de um ambiente construído conceitualmente a partir de 
informações científicas precisas, mas de um ambiente repleto de significados, de magias, de mitos e carregados das nostalgias que lhe atribuímos. J á não falamos do funcionamento de um sistema qualquer que garante nossas atividades de sobrevivência, mas falamos do lugar que nos despertou laços topofílicos, onde estamos inseridos, onde damos vazão aos nossos instintos biofílicos. Dessa forma, a via racional não se isola, não se contrapõe e não reprime a dimensão emotiva da percepção, mas abre-Ihe espaço, soma-se a ela, utiliza-a como terreno fértil às construções de novas visões de mundo" (MARIN, OLIVEIRA \& COMAR, 2003, p.619).

Ao longo dos 16 anos em que foram realizadas as viagens (e os debates na atividade de fechamento) foi ficando cada vez mais evidente que a substituição das atividades centradas no raciocínio, na compreensão conceitual dos aspectos ambientais, por outras que estimularam as sensações e emoções atingiam mais eficazmente os objetivos de sensibilização e tornaram os depoimentos mais coerentes, previsíveis e apaixonados. A sinceridade com que os comportamentos pró-ambiente foram aflorando, tanto durante como após as viagens, refletem a força que o contato intensificado com o meio natural possui para eliciá-los. Os participantes gostam cada vez com mais intensidade do lugar visitado quanto mais intenso for o contato "físico" e "psicológico" com ele? As representações sociais (culturais) de valoração da natureza ficam mais evidentes quanto mais próximos estamos das sensações que ela nos provoca? Após a observação sistemática das transformações pelas quais passam os participantes destas experiências nos faz acreditar em respostas positivas para cada uma dessas questões.

As Impressões dos participantes das viagens, recolhidas através de depoimentos em encontros informais mesmo muito tempo depois das mesmas terem ocorrido, reafirmam o caráter duradouro dessas transformações. Vale ressaltar que, por força da experiência, um número significativo de participantes resolveu aprofundar seus conhecimentos sobre as questões ambientais e se tornaram profissionais da área, conforme relatado e acompanhado também informalmente. 
Após as 107 viagens, já com um indicativo de que o roteiro desenvolvido pela técnica da observação participante é eficiente para eliciar comportamentos pró-ambientes, pôde-se elaborar a hipótese central deste trabalho e partir para uma tentativa de sua comprovação, onde, através pesquisas e de um arranjo experimental, se testou mais detalhadamente as possíveis transformações ocorridas após a realização de contato dirigido com a natureza.

Defende-se aqui que, nas atividades dirigidas de contato com a natureza (sendo o Ecoturismo uma das possibilidades de promovê-las), os marcos afetivos, gerados pelo contato sensorial e emocional com a natureza, introduzem uma grande diferença do ponto de vista motivacional contribuindo para a transformação de valores a atitudes na direção pró-ambiente. A hipótese central que se deseja testar, portanto, é a de que essas atividades podem contribuir significativamente para transformação de valores e atitudes individuais, desde que sejam conduzidas de modo profissional e os agentes eliciadores dos comportamentos pró-ambiente possam estar presentes.

\section{Objetivo Geral:}

Gostar da natureza pode ser um sentimento afetado por representações sociais, o que reforça a importância de como será conduzido, dirigido, o contato com a natureza em atividades de Educação Ambiental e Ecoturismo.

Assim, o principal objetivo deste trabalho é verificar, através da aplicação de instrumentos metodológicos apropriados, as possíveis mudanças de valores e atitudes dos participantes de atividades ecoturísticas dirigidas, onde podem estar expostos à experiências significativas de vida, bem como verificar a possível aquisição de conhecimento, alteração de sentimento e vieses paradigmáticos.

Não foi um objetivo aqui comparar diferentes formas de dirigir atividades de campo, que pode ser um desenvolvimento possível deste estudo. 


\section{Objetivos Específicos:}

- Analisar as principais motivações para a realização de viagens às áreas naturais junto aos seus freqüentadores;

- detectar os principais os fatores determinantes para a conversão aos comportamentos pró-ambiente entre Educadores Ambientais e outros profissionais da área, bem como correlacioná-los às estratégias de trabalho que os mesmos entendem como adequadas para o trabalho com a temática ambiental;

- analisar a influência das atividades de contato com a natureza na percepção dos visitantes no que concerne à diferenciação entre os paradigmas de "Desenvolvimento Sustentável" e "Sociedade Sustentável".

Pode-se dizer que as perguntas deste trabalho resumem-se à:

1) Questões para estudos iniciais e que objetivam situar o contexto motivacional em visitantes de parques e em profissionais de Educação Ambiental:

1a) O Ecoturismo é um fenômeno contemporâneo que tem alavancado um mercado crescente e movimentado significativamente a economia. Esse segmento sobrevive do anseio de cidadãos, normalmente das áreas urbanas, em visitar Parques e Reservas Naturais. A primeira questão que se apresenta, refere-se a quais são as principais motivações dos freqüentadores de áreas naturais que os fazem viajar, às vezes por grandes distâncias, para encontrá-las?

1b) O número de profissionais e simpatizantes da causa ambiental tem aumentado nas duas últimas décadas. Isso se deve ao agravamento dos problemas causados pelo modelo de desenvolvimento vigente, que impõem à sociedade 0 desafio de buscar alternativas que possam compatibilizar a melhoria da qualidade de vida humana com a conservação dos recursos naturais. Apesar de já haver um razoável número de Educadores Ambientais na sociedade, essa atividade ainda tem sido insuficiente para uma real transformação de valores e atitudes na maioria 
dos indivíduos, indicando um possível distanciamento entre teoria e prática nesse segmento. Quais teriam sido os fatores determinantes para a conversão aos comportamentos pró-ambiente nessa parcela da população? Estariam eles atuando conforme sugerem esses acontecimentos de sua história pessoal de vida?

2) Questões para uma verificação controlada a respeito de uma possível ferramenta de Educação Ambiental para a modificação das atitudes próambiente:

2a) Ser "ambientalmente consciente" implica num conjunto de características pessoais, entre as quais destacam-se os conhecimentos, os sentimentos, os valores e as atitudes individuais diante da questão. Seria o contato direto e dirigido com o ambiente natural capaz de desenvolver essas características? Dentre elas, quais poderiam ser mais trabalhadas quando se realiza o contato dirigido com a natureza?

2b) Um debate candente entre os especialistas neste início de século refere-se as diferenças conceituais e metodológicas entre a Educação para o Desenvolvimento Sustentável e a Educação para as Sociedades Sustentáveis. Seriam as atividades de contato dirigido com a natureza suficientes para que os cidadãos incorporem as diferentes concepções paradigmáticas dessas vertentes? 


\section{3 \\ Estudos Exploratórios}

Estes estudos foram realizados com o intuito de contribuir para a formulação das hipóteses deste trabalho, aproveitando oportunidades de recolher informações iniciais, ainda sem tratamento experimental. O primeiro estudo foi possível graças ao apoio do Instituto de Pesquisas Econômicas da USP (FIPE), e o segundo pela participação do pesquisador no ॥o Encontro Estadual de Educação Ambiental (EEEA) e na Pré-conferência Nacional do Meio Ambiente, aproveitando a reunião de um grande número de profissionais e interessados pela temática da Educação Ambiental.

\section{Estudo 1: Quais são as motivações para visitas à natureza?}

\section{Método}

Para recolher opiniões sobre os motivos que levam pessoas para conhecer a natureza em alguns dos mais consagrados destinos ecoturísticos do Brasil, foi aplicada uma pergunta inserida em um questionário amplo sobre turismo em Unidades de Conservação. Esta foi uma oportunidade oferecida pela Fundação Instituto de Pesquisas Econômicas da USP (FIPE) em parceira com o Instituto Brasileiro de Turismo (Embratur) e o Instituto Brasileiro de Meio Ambiente e dos Recursos Naturais Renováveis (Ibama), que realizava uma pesquisa mais ampla sobre o perfil dos visitantes dessas Unidades de Conservação brasileiras 
e, gentilmente, incluiu uma questão para atender aos objetivos deste estudo e responder à primeira questão aqui formulada: quais são as principais motivações dos freqüentadores de áreas naturais que os fazem viajar, às vezes por grandes distâncias, para encontrá-las? Esta oportunidade permitiu que, através de uma amostragem significativa, fosse feita uma sondagem inicial sobre essas motivações e contribuiu para a formulação das hipóteses deste trabalho.

A pesquisa foi efetuada em três períodos distintos. O primeiro período, denominado de "alta estação", ocorreu no decorrer do mês de julho de 2002, quando foram aplicados 2.309 questionários. O segundo período, denominado de "média estação", ocorreu no decorrer do mês de setembro de 2002, por ocasião do feriado da independência, com 2.208 aplicados. O terceiro período ocorreu na segunda metade de setembro e no decorrer do mês de outubro de 2002, e foi denominado de "baixa estação", quando 1.730 questionários foram aplicados totalizando assim 6.247 entrevistas. O tamanho da amostragem seguiu padrões adotados pela FIPE para pesquisas similares, conforme as características de visitação das áreas e critérios estatístico estabelecidos pela Embratur e pelo lbama, que apontam para 6000 entrevistas como mínimo necessário para este caso. A Amostra efetivamente realizada superou, portanto, em quase $5 \%$ o número de elementos planejados. Os resultados não acusaram diferenças significativas nas características dos visitantes entre as três estações.

Os locais escolhidos para a aplicação dos questionários e as respectivas porcentagens estão relacionados na TABELA 1. Vale ressaltar que a pesquisa foi encomendada pelo Ibama e pela Embratur nessas localidades, sendo o critério de escolha a diversidade de ambientes e de Estados da União, número de visitantes e existência de estrutura para visitação. $O$ critério de distribuição de questionários por área de conservação foi o da proporcionalidade de visitações, com base nos dados até então disponíveis e fornecidos pelos órgãos públicos que administram as áreas pesquisadas. 
TABELA 1: Amostra Realizada, por Área e Estação

\begin{tabular}{|c|c|c|c|c|c|c|c|c|}
\hline \multirow{3}{*}{ Local } & \multicolumn{8}{|c|}{ Estações } \\
\hline & \multicolumn{2}{|c|}{ Alta } & \multicolumn{2}{|c|}{ Média } & \multicolumn{2}{|c|}{ Baixa } & \multicolumn{2}{|c|}{ Total } \\
\hline & $\mathrm{N}$ & $\%$ & $\mathrm{~N}$ & $\%$ & $\mathrm{~N}$ & $\%$ & $\mathrm{~N}$ & $\%$ \\
\hline Parque Nacional de Itatiaia - RJ & 314 & 5,0 & 338 & 5,4 & 233 & 3,7 & 885 & 14,2 \\
\hline Parque Nacional de Aparados da Serra - RS & 69 & 1,1 & 150 & 2,4 & 155 & 2,5 & 374 & 6,0 \\
\hline Fernando de Noronha - PE & 262 & 4,2 & 155 & 2,5 & 100 & 1,6 & 517 & 8,3 \\
\hline Parque Nacional de Caparaó - MG & 131 & 2,1 & 174 & 2,8 & 144 & 2,3 & 449 & 7,2 \\
\hline Parque Nacional de Foz do Iguaçu - PR & 555 & 8,9 & 430 & 6,9 & 336 & 5,4 & 1321 & 21,2 \\
\hline Parque Nacional de Chapada dos Veadeiros - GO & 200 & 3,2 & 136 & 2,2 & 112 & 1,8 & 449 & 7,2 \\
\hline Pantanal - MT & 298 & 4,8 & 100 & 1,6 & 65 & 1,0 & 463 & 7,4 \\
\hline Parque Estadual do J alapão - TO & 69 & 1,1 & 25 & 0,4 & 24 & 0,4 & 118 & 1,9 \\
\hline Região de Manaus - AM & 218 & 3,5 & 225 & 3,6 & 118 & 1,9 & 561 & 8,9 \\
\hline APA de Brotas - SP & 193 & 3,1 & 475 & 7,6 & 443 & 7,1 & 1110 & 17,8 \\
\hline Total & 2309 & 37 & 2208 & 35,4 & 1730 & 27,6 & 6247 & 100 \\
\hline
\end{tabular}

Em cada localidade, os entrevistados eram abordados e convidados a conversar rapidamente sobre alguns aspectos da visitação. Essas conversas forneceram algumas informações qualitativas. Em seguida foi perguntado qual o motivo principal que os levavam a realizar viagens às áreas naturais, sendo apresentado-Ihes as seguintes opções para escolha:

Questão: Qual o motivo de sua visita a esta área natural?
a) Contemplação ou contato com a natureza
b) Repouso ou fuga da rotina
c) Prática de esportes
d) Aprendizagem sobre ecologia
e) Estudos e pesquisas
f) Estímulo de reportagens ou documentários
g) Assuntos profissionais
h) Campismo
i) Adesão à tendência pelo Ecoturismo
j) Religiosidade/Esoterismo/Espiritualidade
k) Participação em eventos
1) Tratamento de saúde
m) Outros Motivos

\section{Resultados}

Quando se analisam as respostas a esta pergunta, nota-se que os motivos se mostraram relativamente homogêneos em todas as áreas conservadas. $A$ principal motivação apontada para as visitas às áreas naturais, em geral, é a 
"Contemplação ou Contado com a Natureza", com 64\% das respostas; seguida de

"Repouso ou Fuga da Rotina", com 22,7\%, acumulando quase $90 \%$ das justificativas apresentadas (TABELA 2). Apesar de haver diferenças relativas entre as freqüências desses itens conforme a localidade, vale ressaltar que essas opções aparecem como as mais escolhidas, independentemente de onde foram recolhidas. No caso da localidade "Brotas", verifica-se um resultado diferenciado no item "Prática de Esportes" (11,9\%), com valor superior às demais localidades para esse item.

TABELA 2: Motivos da Visita às Unidades de Conservação em Geral

\begin{tabular}{|c|c|c|c|c|c|c|c|c|c|c|c|}
\hline \multirow[b]{2}{*}{ Motivos } & \multicolumn{11}{|c|}{ Localidades } \\
\hline & $\begin{array}{c}\text { Aparados } \\
\text { da Serra }\end{array}$ & Brotas & Caparaó & $\mid \begin{array}{c}\text { F. de } \\
\text { Noronha }\end{array}$ & $\begin{array}{l}\text { Foz do } \\
\text { Iguaçu }\end{array}$ & Itatiaia & J alapão & Manaus & Pantanal & $\begin{array}{c}\text { Chapada } \\
\text { dos } \\
\text { Veadei- } \\
\text { ros }\end{array}$ & Total \\
\hline $\begin{array}{l}\text { Contemplação ou contato com a } \\
\text { natureza }\end{array}$ & $71,6 \%$ & $47,7 \%$ & $63,0 \%$ & $65,0 \%$ & $78,8 \%$ & $66,3 \%$ & $59,8 \%$ & $50,0 \%$ & $67,9 \%$ & $63,6 \%$ & $64,0 \%$ \\
\hline Repouso ou fuga da rotina & $11,7 \%$ & $34,2 \%$ & $24,6 \%$ & $19,2 \%$ & $11,0 \%$ & $23,5 \%$ & $26,9 \%$ & $32,4 \%$ & $18,5 \%$ & $28,3 \%$ & $22,7 \%$ \\
\hline Prática de esportes & $1,6 \%$ & $11,9 \%$ & $3,3 \%$ & $6,2 \%$ & $0,9 \%$ & $2,3 \%$ & $6,7 \%$ & $1,0 \%$ & $2,8 \%$ & $2,6 \%$ & $4,1 \%$ \\
\hline Aprendizagem sobre ecologia & $4,8 \%$ & $0,7 \%$ & $1,1 \%$ & $1,6 \%$ & $4,4 \%$ & $2,0 \%$ & $1,7 \%$ & $3,4 \%$ & $5,0 \%$ & $1,3 \%$ & $2,6 \%$ \\
\hline Estudos e pesquisas & $3,5 \%$ & $0,8 \%$ & $1,1 \%$ & $0,6 \%$ & $0,5 \%$ & $2,6 \%$ & $0,8 \%$ & $2,2 \%$ & $2,4 \%$ & $1,8 \%$ & $1,5 \%$ \\
\hline $\begin{array}{l}\text { Estímulo de reportagens ou } \\
\text { documentários }\end{array}$ & $3,8 \%$ & $0,7 \%$ & $0,9 \%$ & $3,9 \%$ & $1,4 \%$ & $1,1 \%$ & $0,0 \%$ & $2,0 \%$ & $1,3 \%$ & $1,1 \%$ & $1,5 \%$ \\
\hline Assuntos profissionais & $1,3 \%$ & $0,4 \%$ & $0,2 \%$ & $1,7 \%$ & $0,8 \%$ & $0,7 \%$ & $0,8 \%$ & $7,0 \%$ & $1,1 \%$ & $0,0 \%$ & $1,3 \%$ \\
\hline Campismo & $0,0 \%$ & $1,4 \%$ & $3,3 \%$ & $0,0 \%$ & $0,5 \%$ & $0,3 \%$ & $1,7 \%$ & $0,0 \%$ & $0,0 \%$ & $0,2 \%$ & $0,7 \%$ \\
\hline Adesão à tendência pelo Ecoturismo & $1,1 \%$ & $1,0 \%$ & $0,9 \%$ & $0,6 \%$ & $0,8 \%$ & $0,8 \%$ & $0,8 \%$ & $0,5 \%$ & $0,2 \%$ & $0,4 \%$ & $0,7 \%$ \\
\hline $\begin{array}{c}\text { Religiosidade/Esoterismo/ } \\
\text { Espiritualidade }\end{array}$ & $0,3 \%$ & $0,3 \%$ & $1,3 \%$ & $0,8 \%$ & $0,2 \%$ & $0,2 \%$ & $0,8 \%$ & $0,5 \%$ & $0,0 \%$ & $0,7 \%$ & $0,4 \%$ \\
\hline Participação em eventos & $0,3 \%$ & $0,6 \%$ & $0,2 \%$ & $0,0 \%$ & $0,2 \%$ & $0,1 \%$ & $0,0 \%$ & $1,1 \%$ & $0,4 \%$ & $0,0 \%$ & $0,3 \%$ \\
\hline Tratamento de saúde & $0,0 \%$ & $0,3 \%$ & $0,0 \%$ & $0,2 \%$ & $0,2 \%$ & $0,1 \%$ & $0,0 \%$ & $0,0 \%$ & $0,0 \%$ & $0,0 \%$ & $0,1 \%$ \\
\hline Outros Motivos & $0,0 \%$ & $0,0 \%$ & $0,0 \%$ & $0,2 \%$ & $0,2 \%$ & $0,0 \%$ & $0,0 \%$ & $0,0 \%$ & $0,4 \%$ & $0,0 \%$ & $0,1 \%$ \\
\hline
\end{tabular}

\section{Discussão}

Verifica-se aqui que o "contato com a natureza" é mencionado por significativa porcentagem de pessoas. As variações de freqüência entre este item e o item "repouso e fuga rotina", verificado entre a localidades (por exemplo entre "Foz do Iguaçu" e "Manaus", ou entre "Aparados da Serra" e "Jalapão") podem ser devido a características intrínsecas às mesmas, que favoreceriam uma ou outra motivação. Isso é muito evidente nas "Cataratas do Iguaçu" e no cannyon do Itaimbezinho, nos parques nacionais de Foz do Iguaçu e Aparados da Serra, respectivamente, atrativos que favorecem muito a contemplação visual, diferentemente de Manaus e Jalapão que favoreceriam mais o repouso e a fuga 
da rotina. Esta é uma hipótese a ser pesquisada, mas parece razoável acreditar que os ambientes possuem potencialidades diferenciadas de motivações conforme seus atrativos naturais. Pelos resultados, outras localidades se mostraram muito procuradas para o repouso, como Caparaó, Chapada dos Veadeiros e Itatiaia, todas com atrativos muito semelhantes (montanhas, cachoeiras e trilhas).

Os relatos informais recolhidos durante a aplicação do questionário, apontam para uma abordagem bastante simbólica com relação aos locais visitados, ora apontados como "natureza intocada", ora como "paraíso preservado". Essa idealização na natureza foi bastante discutida por Bachelard (1993), que afirma que as paisagens naturais passam a ser desejadas pela imaginação humana como um espaço a ser vivido e reverenciado na forma do que chamou de "bosque-catedral". Esse fenômeno também foi apontado por Chauí (2000), para quem as representações do "mito fundador" podem justificar uma imagem do "natural" como o espaço do repouso, aquele no qual o cidadão será colocado em contato direto com a beleza, sendo, portanto, ideal para a contemplação. Nessa direção, uma possível interpretação para os dados da TABELA 2, é que esse ideário de paraíso edênico, reforçado pela sociedade contemporânea e pelo mercado de Ecoturismo, é apresentado como o contraponto a uma vida urbana estressante e privada da presença da "pureza". Isso pode fazer com que, inconscientemente, os viajantes sejam movidos às áreas naturais por motivos com grande apelo emocional, mesmo parecendo ser a viagem uma decisão tomada com a racionalidade.

Mesmo que se levantem suspeitas a respeito da influência da cultura (aspectos sociais) sobre os motivos "contemplação da natureza" e "repouso e fuga da rotina", não há como não deixar de supor que o impulso ao prazer, mesmo que provocado pela busca de meras representações construídas por essa cultura (o paraíso edênico) possa explicar as opiniões da maioria dos entrevistados. Há uma relação direta entre a experiência de interação do ser humano com a natureza e a experiência estética, intencionalmente buscada nas viagens à áreas naturais (MARIN, OLIVEIRA \& COMAR, 2005). 
É interessante, também, observar a diferença existente entre os destinos "Foz do Iguaçu" e "Brotas", no que se refere aos motivos "contemplação da natureza" (78,8\% e $47,7 \%$, respectivamente, a maior e a menor dentre todos os demais) e "prática de esportes" (0,9\% e $11,9 \%$, respectivamente, a menor e a maior dentre todos os demais), pois esses resultados, mais uma vez, apontam que há motivações diferenciadas quando os destinos possuem (ou são associados pelo trabalho da mídia e outros segmentos da sociedade) atrativos e potenciais bastante distintos. Neste caso, como já foi dito, as Cataratas do Iguaçu são muito apreciadas, pela sua incontestável beleza cênica, para um turismo de contemplação (apesar de haver prática de esportes de aventura no Parque Nacional) e Brotas vem se destacando como a "capital dos esportes de aventura" do Estado de São Paulo, sendo o principal destino desse tipo de atividade dentre as agência de Ecoturismo.

Outro resultado que merece destaque é a baixa freqüência para a motivação "Estímulo de reportagens ou documentários" em todas as localidades, uma vez que há uma crença no poder da mídia para a formação do desejo de consumo. Pelo menos no que se refere ao Ecoturismo, esse efeito não parece ser o mais importante. As respostas dos sujeitos sugerem que o desejo por contato com a natureza parece depender bem mais de fatores culturais, de moda, da fama e das características dos locais visitados.

Uma vez que a natureza, como aponta o Estudo 1, parece estar transformada por representações sociais que a associam com um ideal a ser buscado pela sociedade contemporânea, pode-se aventar a hipótese de que 0 contato direto seja um dos agentes capazes de proporcionar experiências significativas de vida e transformar valores e atitudes. 
Estudo 2: Quais são suas motivações para o comportamento próambiente dos Profissionais e Educadores Ambientais?

Método

Durante a realização do IIํㅡㄹ Encontro Estadual de Educação Ambiental (IIำ EEEA), realizado nos dias 24, 25 e 26 de julho de 2003 em Rio Claro - SP, aplicou-se um questionário simples aos participantes, na grande maioria profissionais envolvidos com o tema e, portanto, sujeitos ecológicos já bem definidos. O objetivo do questionário foi resgatar o motivo original principal da opção pelo envolvimento pela temática ambiental, e as opiniões sobre estratégias mais eficientes para a Educação Ambiental.

Foram apenas duas as perguntas presentes nos 500 questionários distribuídos (25\% dos participantes), ambas na forma de testes de múltipla escolha (6 alternativas), sendo que se obteve o retorno de 217. Para cada pergunta, os entrevistados deveriam escolher três respostas, hierarquizando-as em 1aㅡ $2^{\underline{a}}$ e $3^{\text {a }}$ opção, conforme cada alternativa the parecesse mais ou menos importante para o seu caso pessoal. Essa hierarquia deveria revelar o grau de valor que cada entrevistado dava à opção apontada.

Questionário aplicado aos Educadores Ambientais

1) Você acredita que para a obtenção de sucesso, um programa de Educação Ambiental deve priorizar:

( ) Análises teóricas dos problemas ambientais (debates, aulas, palestras etc.);

( ) Contato direto com ambientes naturais (excursões, piqueniques, caminhadas etc.);

( ) Contato com profissionais da área (conversas, estágios, trabalhos em parceria etc.);

( ) Campanhas e festividades envolvendo toda a comunidade;

( ) Atividades práticas e lúdicas (uso de sucata, brincadeiras, reciclagem, hortas etc.);

( ) Outros. Quais?

2) Você avalia que seu interesse pela Educação Ambiental foi despertado, principalmente:

( ) Pela divulgação do tema na mídia;

( ) Por sua atividade profissional;

( ) Pelo contato com a natureza na infância, adolescência ou mesmo na vida adulta;

( ) Através do exemplo de pessoas que influenciaram sua percepção sobre o tema (pais, professores, ambientalistas etc.);

( ) Por sua atuação no movimento ambientalista;

( ) Outros. Quais? 
O mesmo questionário foi aplicado em um outro evento que reuniu atores sociais interessados na questão ambiental. Trata-se da Pré-conferência Nacional do Meio Ambiente, realizada nos dias 24, 25 e 26 de outubro de 2003 em Botucatu - SP, desta vez reunindo não apenas educadores, mas diversos outros segmentos da sociedade e profissionais do meio ambiente. O objetivo do questionário foi o mesmo: resgatar o motivo original da opção pela temática ambiental desses atores sociais, e as opiniões sobre estratégias mais eficientes para a Educação Ambiental.

Desta vez foram distribuídos 400 questionários (novamente $25 \%$ dos participantes), sendo que se obteve o retorno de 170. Como no grupo de educadores ambientais de Rio Claro, para cada pergunta, os entrevistados deveriam escolher três respostas, hierarquizando-as em $1^{\underline{a}}, 2^{\underline{a}}$ e $3^{a}$ opção, conforme cada alternativa lhe parecesse mais ou menos importante.

\section{Resultados}

Pergunta 1

No caso dos participantes do ॥ EEEA, considerando-se apenas a primeira opção de cada entrevistado, duas alternativas se destacam: as "análises teóricas sobre problemas ambientais" e o "contato direto com a natureza" (FIGURA 5). Esse resultado revela a principal dicotomia existente entre os Educadores Ambientais: os que valorizam o conhecimento como forma de convencimento para a busca da sustentabilidade e os que confiam na sensibilização como estratégia mais eficiente: 


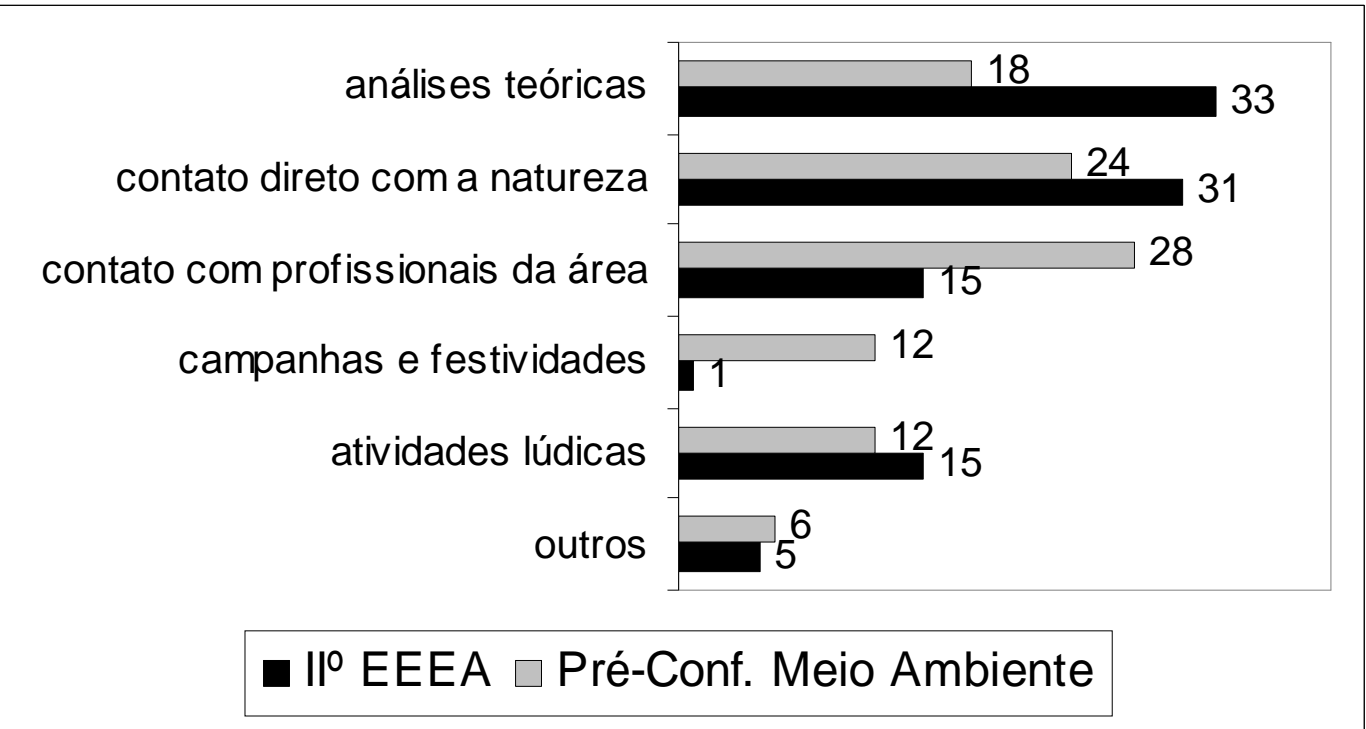

FIGURA 5: Razões para o sucesso de um programa de Educação Ambiental apontadas por especialistas reunidos em Rio Claro - SP em julho de 2003 e em Botucatu em outubro de 2003 (1 ${ }^{\text {a }}$ opção de cada entrevistado, em porcentagem).

No caso dos participantes da Pré-conferência Nacional do Meio Ambiente, as respostas dos participantes se mostraram muito semelhantes àquelas dadas pelos educadores ambientais. Ao considerar-se apenas a primeira opção, duas alternativas se destacam: o "contato com profissionais da área" e o "contato direto com a natureza" (FIGURA 5). Mais uma vez se aparece uma possível a dicotomia entre os que valorizam os aspectos da racionalidade (aqui representada pelo contato com "especialistas") e os que confiam na capacidade de sensibilização pelo contato com a natureza.

\section{Pergunta 2}

Se a análise for restrita para apenas a $1^{\text {a }}$ opção de cada entrevistado do IIo EEEA, a opção "contato direto com natureza" se destaca, mas as opções "exemplos de pessoas" e, principalmente, "atividade profissional" aparecem com freqüências relevantes (FIGURA 6): 


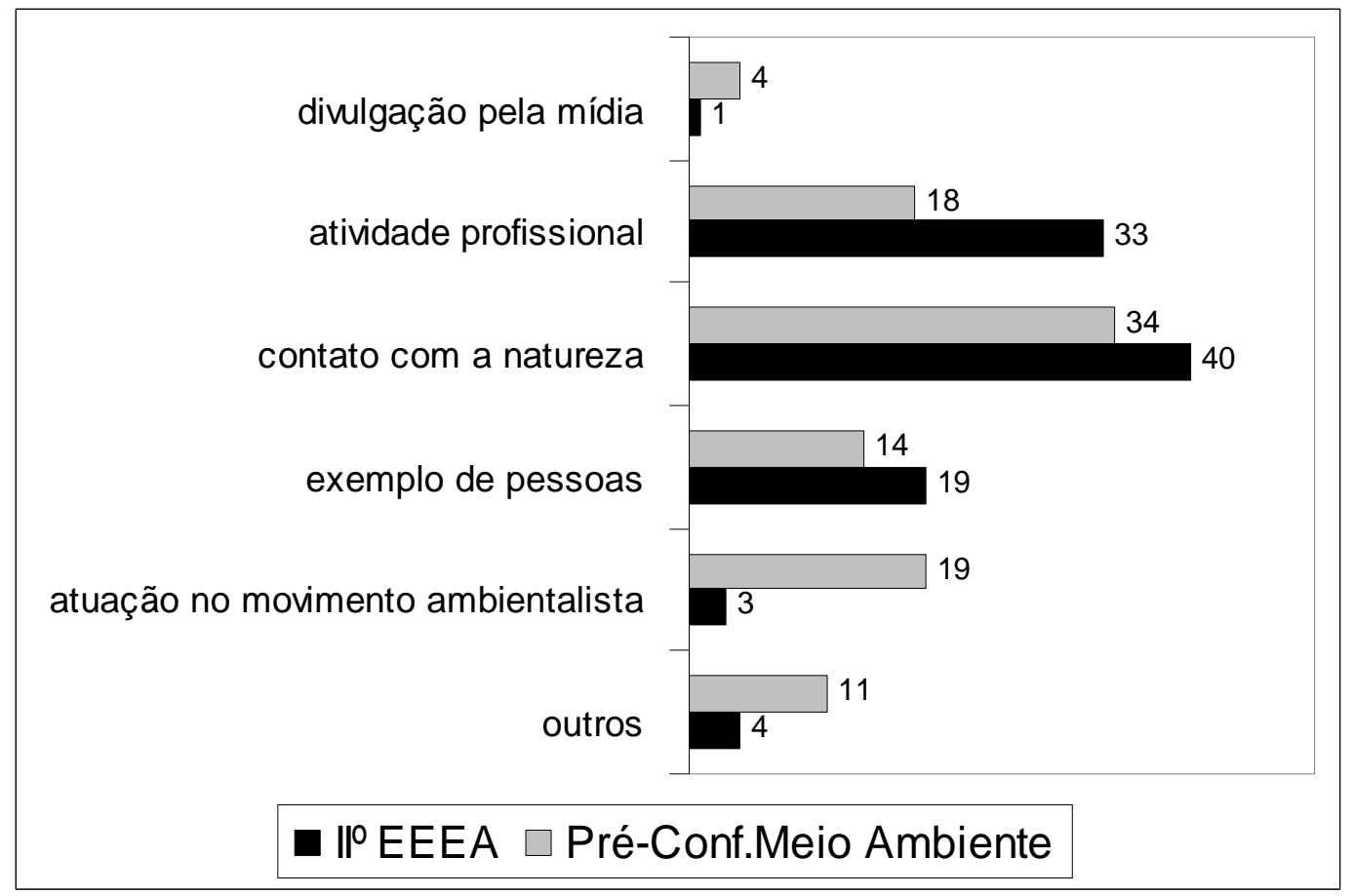

FIGURA 6: Motivos de interesse pessoal pela Educação Ambiental apontados por especialistas reunidos em Rio Claro - SP em julho de 2003 e em Botucatu em outubro de 2003

(1ํㅡㄹ opção de cada entrevistado, em porcentagem).

Ao analisar-se, mais uma vez, apenas a primeira opção das motivações pessoais para inserção na questão ambiental dos atores da temática ambiental presente da Pré-conferência de Meio Ambiente, nota-se que a opção "contato direto com natureza" volta a se destacar, desta vez com mais intensidade que no Grupo de Rio Claro, havendo freqüência muito próximas entre as opções "atuação no movimento ambientalista", e "atividade profissional" (FIGURA 6). Tal diferença poderia ser justificada pela grande quantidade de entidades militantes da causa ambientalista presente em Botucatu (era o grupo mais numeroso do evento).

Por acreditar que a opção "atividade profissional" possa estar "encobrindo" o real motivo para a inserção dos profissionais na Educação Ambiental e dos participantes da Pré-conferência de Meio Ambiente, uma vez que muitos podem ter confundido a idéia de "motivação original" com a "satisfação pessoal pelo trabalho na área", analisou-se a 2 ${ }^{\text {a }}$ opção apontada apenas pelos especialistas que elegeram a "atividade profissional" como 1ำ opção, e então se 
revelou a marcante influência que o "contato com a natureza" e os "exemplos de pessoas" exerceram sobre elas (FIGURA 7):

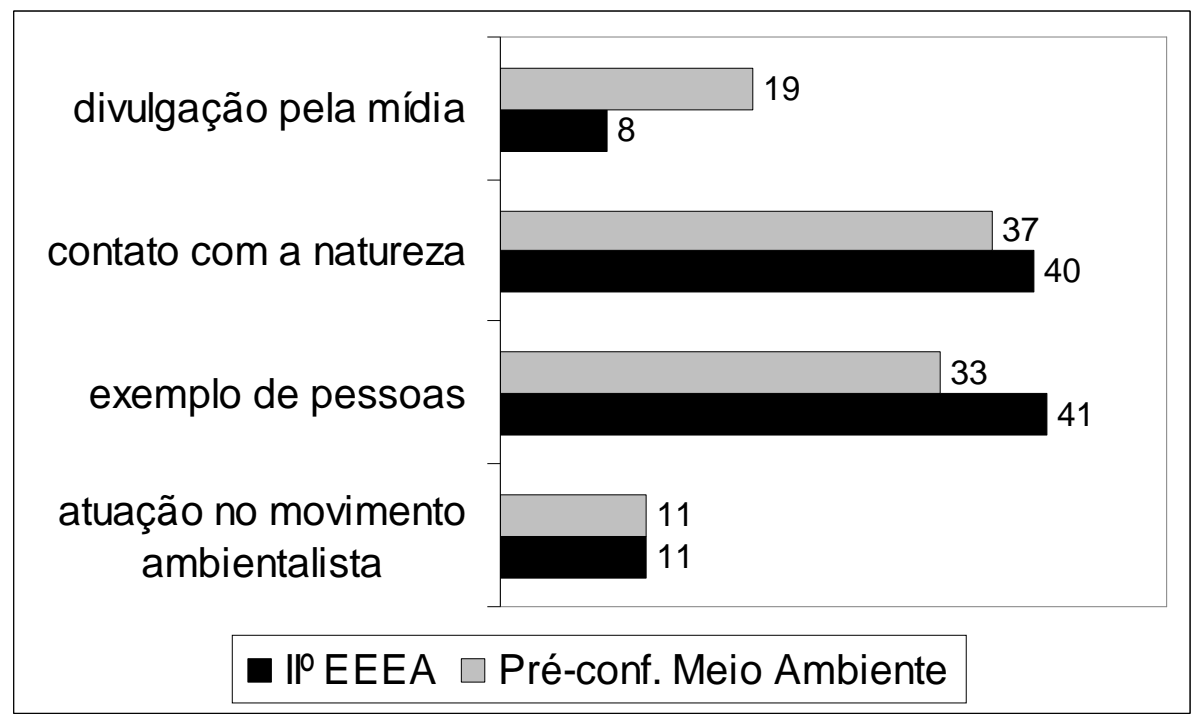

FIGURA 7: 2ª opção apontada por especialistas reunidos em Rio Claro - SP em julho de 2003 e em Botucatu em outubro de 2003 que alegaram "atividade profissional" como $1^{\text {a }}$ opção (em porcentagem).

Apesar de ser apontado com a maior freqüência entre os entrevistados, o contato com a natureza parece ser menos significativo nas estratégias que os mesmos alegam ser eficientes. Surge um contra-senso quando se cruzam duas informações contidas nas respostas aos questionários. Ao observar-se qual a estratégia de Educação Ambiental mais eficiente (questão 1) na opinião dos profissionais que apontaram como motivação pessoal mais importante (questão 2) o "contato com a natureza", nota-se que, esquecendo-se do próprio processo pessoal, as alternativas "análises teóricas" e "campanhas e festividades" são lembradas com mais intensidade, demonstrando o peso que as questões da racionalidade apresentam quando se fala da profissionalização da Educação Ambiental (FIGURA 8). 


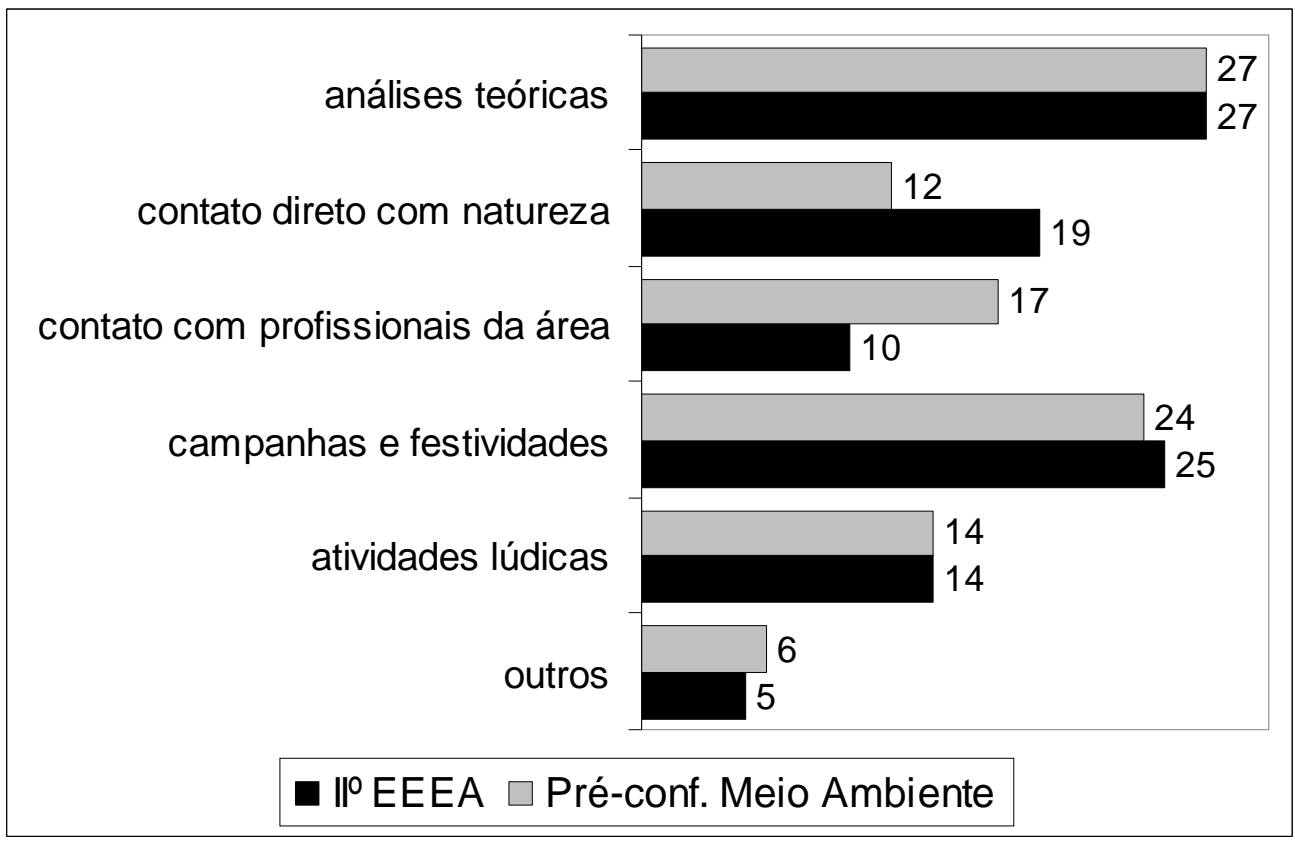

FIGURA 8: Opinião sobre a melhor estratégia de EA dos especialistas reunidos em Rio Claro - SP em julho de 2003 e em Botucatu em outubro de 2003 que alegaram "contato com natureza" como motivação pessoal mais importante para adesão a causa ambiental (em porcentagem).

\section{Discussão}

Ao se analisar a FIGURA 8, constata-se que parece existir um grande mito na sociedade contemporânea de que a educação é a mera transmissão de conhecimentos do educador para o educando ou no máximo, quando bem realizada, é uma interpretação, uma tradução de conhecimentos de forma que o mesmo seja compreensível. Essa visão, não consegue quebrar a relação racional entre o indivíduo e o objeto de estudo pois partem do pressuposto de que é na razão que está o filtro principal da relação do ser humano com o espaço em que ele vive. Existem aspectos mais complexos, que passam pela intuição, pelos sentimentos e pela afetividade e que não são, normalmente, trabalhados pela educação formal, que ainda é entendida como a compreensão racional do mundo em que se vive (MENDONÇA \& NEIMAN, 2003). No entanto os especialistas entrevistados neste estudo, sem dar ouvidos aos próprios sentimentos e experiências, preferem "profissionalizar" seus procedimentos segundo a lógica positivista (análises teóricas) ou, no máximo, das relações sociais amenas (campanhas e festividades), que também carregam aspectos 
dessa mesma lógica. Compreendendo que não há dicotomia entre os aspectos racionais e emocionais do ser humano, o ideal seria um trabalho educacional que contemplasse ambos.

Vale ressaltar, finalmente, que nos resultados obtidos talvez estejam embutidas respostas que, muitas vezes, não aparecem em questionários fechados como os que foram aplicados. Desta forma, não se pode afirmar que haja uma predominância da "análise teórica" ou "contato com profissionais" em relação ao "contato dirigido com a natureza" (ver FIGURA $5-31 \%$ e $33 \%$; $28 \%$ e 24, respectivamente) exclusivamente com os dados obtidos, pois talvez os entrevistados gostariam de apontar, simultaneamente, as duas razões, que apresentaram valores próximos, demonstrando que os dois podem ser importantes, pelo menos na visão dos entrevistados. Talvez se o questionário apresentasse a possibilidade do entrevistado justificar a 1 a opção, isso ficasse mais evidente. Há que se tomar cuidado, portanto, com as conclusões mesmo quando se analisa a FIGURA 8, pois essa limitação do método pode estar influindo também nesses resultados. Mesmo acreditando na existência da "dicotomia" aqui citada, pode-se apenas se valer do que os dados numéricos dizem, já que não há outra fonte de análise.

No entanto, pelos resultados observados nesses dois estudos iniciais, ou seja, os motivos relatados pelos freqüentadores de áreas naturais, e as respostas dadas pelos educadores e ambientalistas aos questionários, foi possível elaborar a hipótese central deste trabalho: os marcos afetivos, gerados pelo contato sensorial e emocional com a natureza, por introduzirem uma grande diferença do ponto de vista motivacional e representar momentos significativos na vida dos indivíduos, seriam mais eficientes na transformação de valores a atitudes na direção pró-ambiente. 


\section{4 \\ Estudos Experimentais}

Os próximos estudos objetivam testar esta hipótese de maneira mais direta e responder as demais perguntas do trabalho: qual seria a conduta mais eficiente para promover o contato direto de grupos de pessoas com a natureza de modo a transformá-lo numa experiência significativa de vida? Dentre as características pessoais (conhecimentos, sentimentos, valores e atitudes individuais), quais poderiam ser mais aprofundadas quando se realiza o contato dirigido com a natureza? Seriam as atividades de contato dirigido com a natureza suficientes para que os cidadãos incorporem as diferentes concepções paradigmáticas das vertentes da Educação Ambiental?

Estudo 3a: Mudanças medidas por Escalas de Avaliação de Sentimentos

Metodologia

O estudo sobre as atitudes e as maneiras como medi-las têm interessado a um grande número de pesquisadores (DARLEY \& GILBERT, 1985; MALONEY et al. , 1975; WEIGEL \& WEIGEL, 1978; DUNLAP \& VAN LIERE, 1978; Van LIERE \& DUNLAP, 1981; DUNLAP, et. al. 2000; DUNLAP, 1993; CASTRO, 2003, STERN et. al., 1995; BECHTEL, 2000; INGLEHART, 1977; DOUGLAS \& WILDAVSKI, 1982).

Atualmente quatro escalas são consideradas "psicometricamente respeitáveis" (DARLEY \& GILBERT, 1985, p. 962): a Escala de Atitudes 
Ecológicas, de Maloney et al. (1975); a Escala de Preocupação Ambiental, de Weigel \& Weigel (1978); a Escala NEP (New Environmental Paradigm), de Dunlap \& Van Liere (1978), e a Escala Analógica de Humor (EAH), de Norris (1971).

O uso de escalas para avaliar sentimentos, conhecidas como Escalas Analógicas de Humor (EAH) vêm sendo utilizadas no Brasil por Del Porto et. al. (1993), Alvarenga \& Nogueira-Filho (2005) e Guimarães et. al. (1988).

O objetivo desse estudo foi analisar programas de Educação Ambiental realizados através da prática do Ecoturismo no PETAR. Para isso, foi avaliado um programa aplicado a estudantes universitários, que visava tornar estes estudantes comprometidos com novos valores, interessados e preocupados com o ambiente em que vivem. Para a sua concretização recorreu-se à aplicação de questionário com afirmativas que testaram quais os valores e sentimentos que a visita provocou, e o quanto a mesma contribuiu para a mudança de atitudes.

Esta fase da pesquisa baseou-se num delineamento também adotado por Padua (1997), e contou com a participação de alunos universitários que foram separados em dois grupos distintos: um Grupo Controle, que não participou de viagem ao PETAR, e outro, o Grupo Experimental, que foi exposto ao programa de visita dirigida. $O$ experimento foi realizado com estudantes de duas Instituições de Ensino Superior, em duas viagens com datas diferentes, sendo que para cada houve um Grupo Controle e outro Experimental (FIGURA 9)

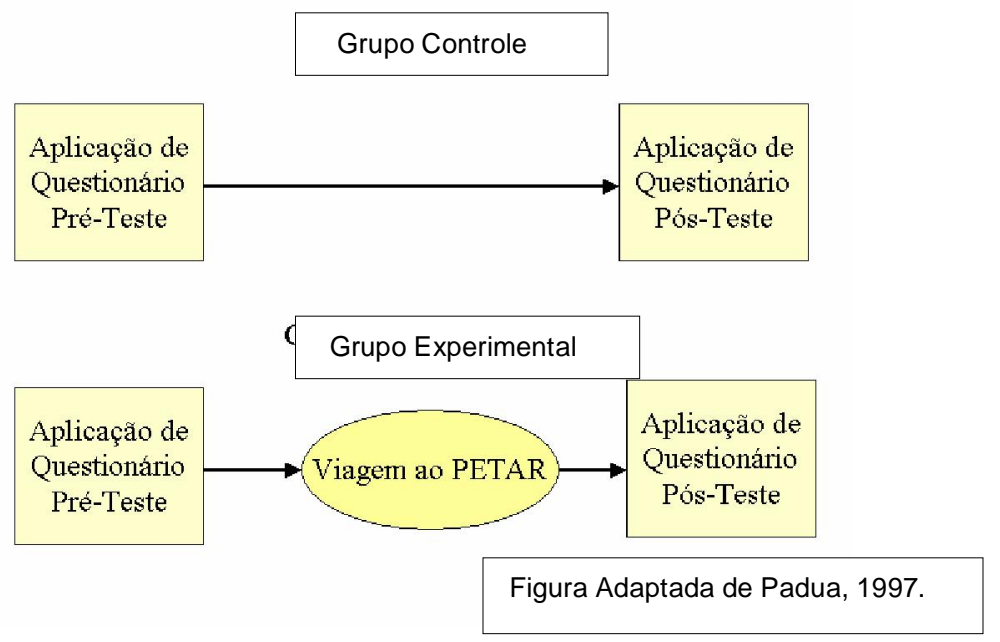

FIGURA 9: Arranjo experimental 
Os alunos do Grupo Experimental participaram da visita ao PETAR, onde, além de conteúdos transmitidos, puderam vivenciar o ambiente.

Os alunos do Grupo Controle responderam ao questionário, nas mesmas datas dos alunos do Grupo Experimental (pré e pós-testes), mas sem participar da viagem ao Parque Estadual Turístico do Alto Ribeira - PETAR.

A hipótese nula dessa pesquisa é a de que não há diferença significativa entre os Grupos Experimentais e os de Controle entre os Pré e Pós-testes.

Para evitar ameaças como a comunicação entre os grupos, o pós-teste foi aplicado imediatamente após o retorno das viagens dos alunos do Grupo Experimental, antes de se encontrarem com membros do Grupo Controle, e simultaneamente para os dois Grupos.

Grupos

A primeira viagem foi realizada no mês de outubro de 2005 com estudantes do $3^{\circ}$ semestre do curso de Pedagogia de uma Faculdade localizada no município de São Paulo - SP (Turma Pedagogia - TP); e a segunda, no mês de junho de 2006, com estudantes de $1^{\circ}$ Semestre do curso de Turismo de uma Universidade localizada no município de Sorocaba, Estado de São Paulo (Turma Turismo - TT). Em ambas as viagens foram selecionadas turmas com características homogêneas de idade e sexo. O total de participantes do arranjo experimental foi de aproximadamente 115 alunos (o número oscilou levemente entre o pré-teste e o pós-teste).

\section{Instrumentos}

(1) escala de sentimentos e conhecimentos

Esta parte do questionário foi elaborada com retas de $100 \mathrm{~mm}$, conhecidas como escalas analógicas visuais (baseadas na Escala Analógica de Humor). No preenchimento dos questionários os entrevistados foram instruídos para que considerassem, no caso do sentimento abordado, o meio da reta como aquele que representaria o seu estado habitual cotidiano, e, no caso dos 
conhecimentos, a gradação de zero a dez, sendo o zero (0) o total desconhecimento e o dez (10) o domínio completo do tema. Assim, quanto mais próximos de zero (0) ou de dez (10) (sendo 5 (cinco) o ponto de partida) maiores as mudanças para sentimentos. Ou seja, quanto mais perto de uma das extremidades da escala, mais próximo o seu sentimento do pólo desta extremidade. Neste experimento só se está interessado pelo estado afetivo presente do indivíduo. No caso da atividade de contato com natureza, como os sentimentos são testados alguns dias depois, se houver diferenças entre pré e pós-experimento e/ou controle e experimental, elas poderão ser atribuídas à atividade. Os sentimentos testados foram: alerta/sonolento, calmo/agitado, idéias claras/confuso, satisfeito/insatisfeito, tranqüilo/preocupado, atento/distraído, alegre/triste, interessado/desinteressado, seguro/inseguro, solitário/integrado, confiante/temeroso, esperançoso/descrente. Para os conhecimentos, quanto mais próximos de dez (10) (sendo zero (0) o ponto de partida), maiores seriam aqueles adquiridos, sendo que o zero representaria o total desconhecimento e dez o domínio completo do tema. Os conhecimentos testados foram: "Mata Atlântica", "cavernas de calcário", "Unidades de Conservação", "meio ambiente”, "Educação Ambiental" e "comunidades tradicionais". Os resultados estão tabulados no Anexo 5.

(2) valores e atitudes pró-ambiente.

As atitudes pró-ambiente dos entrevistados foram medidas, também, a partir de escalas analógicas visuais, com a mesma orientação do caso dos "conhecimentos". Os resultados estatísticos encontrados nesta parte do questionário seguiram o mesmo procedimento das escalas anteriores, ou seja, quanto mais próximos de dez (10) (sendo zero (0) o ponto de partida), maiores seriam os desejos por adotar os valores e atitudes, sendo que o zero representaria a total falta de vontade de fazê-lo. Os resultados também estão tabulados no Anexo 5. As perguntas e afirmativas que mediram os valores relatados (opiniões) após experiência dirigida de contato com a natureza são (TABELA 3): 
TABELA 3: Questões relativas a valores.

\begin{tabular}{|c|c|}
\hline & Questões \\
\hline 1. & O que você acha da relação dos animais da mata com o homem? \\
\hline 2. & O que você sente quando ouve falar sobre a extinção de plantas e animais? \\
\hline 3. & Qual sua emoção ao entrar em uma mata? \\
\hline 4. & O que você sente sobre a caça e a venda de animais silvestres? \\
\hline 5. & O que você sente quando vê áreas de mata queimando? \\
\hline 6. & $\begin{array}{l}\text { Você concorda com a afirmação "Garantir a preservação de uma espécie é } \\
\text { garantir a preservação da mata" }\end{array}$ \\
\hline 7. & O que você sente ao entrar numa caverna de calcário? \\
\hline 8. & $\begin{array}{l}\text { Você concorda com a afirmação "o modo de vida das populações } \\
\text { tradicionais deve ser mantido"? }\end{array}$ \\
\hline 9. & O que você sente ao visitar áreas naturais? \\
\hline 10. & $\begin{array}{l}\text { Você concorda com a afirmação "a preservação da Mata Atlântica é } \\
\text { urgente"? }\end{array}$ \\
\hline 11. & O que você sente quando está em contato direto com a Natureza? \\
\hline 12. & $\begin{array}{l}\text { Você concorda com a afirmação "a natureza ensina ao ser humano como } \\
\text { ele deve viver"? }\end{array}$ \\
\hline 13. & $\begin{array}{l}\text { Você concorda com a afirmação "os ambientalistas são pessoas que } \\
\text { deveriam pensar mais no desenvolvimento da sociedade"? }\end{array}$ \\
\hline
\end{tabular}

As atitudes pró-ambiente foram medidas a partir da manifestação do quanto os entrevistados estariam dispostos à (TABELA 4):

TABELA 4: Questões relativas a atitudes

\begin{tabular}{|r|l|}
\hline & \multicolumn{1}{|c|}{ Questões } \\
\hline A. & Participar do movimento ambientalista; \\
\hline B. & Mudar seus hábitos de consumo; \\
\hline C. & Visitar áreas naturais; \\
\hline D. & Usar menos o carro; \\
\hline E. & Divulgar a preservação ambiental; \\
\hline F. & Fazer cursos na área ambiental; \\
\hline G. & Pesquisar e escrever artigos sobre Meio Ambiente; \\
\hline H. & Rever seus hábitos cotidianos de modo a economizar recursos; \\
\hline I. & Ler a respeito ou assistir documentários sobre meio ambiente; \\
\hline J. & Ser mais integrado às outras pessoas; \\
\hline K. & Espiritualizar-se; \\
\hline L. & Cuidar de plantas e animais \\
\hline M. & Reciclar o lixo; \\
\hline N. & Filiar-se à uma ONG ambientalista; \\
\hline O. & Doar recursos ou trabalhar voluntariamente para a Conservação Ambiental; \\
\hline P. & Pagar mais impostos, desde que os mesmos sejam revertidos para \\
\hline
\end{tabular}


O banco de dados foi preparado com as observações referentes às medidas pré e pós-intervenção, dos grupos controle e experimental, e em cada turma (TP e TT).

Resultados

Primeiramente, são apresentadas, no Anexo 1, as estatísticas descritivas (número de observações, média, mediana e desvio padrão) para cada uma das variáveis, e em cada um dos grupos considerados. Aplicou-se os testes de normalidade de Shapiro-Wilk e de Kolmogorov-Smirnov. Os resultados (valor $p$ ) desses testes, aplicados em todas as variáveis respostas, em cada um dos 4 grupos de pesquisa, indicaram que a variável não segue uma distribuição aproximadamente Normal (114 indicam distribuição normal e 382 não são normais), com um nível de significância de $5 \%$. Por isso, optou-se por testes não paramétricos em todas as análises estatísticas realizadas.

TP X TT - o efeito da turma sobre o escore dos indivíduos

Para o Teste de Hipóteses, primeiramente considerou-se o efeito da turma sobre a resposta média dos indivíduos. As duas turmas (TP e TT) formam grupos independentes. Elas serão comparadas entre si em cada uma das medidas: pré e pós, nos grupos controle e experimental. $O$ teste não paramétrico utilizado para comparação de dois grupos independentes é o Teste de MannWhitney. Os resultados são expressos pelo valor $p$ do teste nas tabelas a seguir, agrupadas por tipo de variável. Valores menores que o nível de significância de $5 \%(0,05)$ indicam que há diferença significativa entre as respostas de TP e TT, e estão assinaladas nas células em negrito. Os resultados obtidos indicam que não há diferença significativa (com algumas exceções, sendo a maioria referente aos sentimentos) entre os grupos Controle (pré e pós), e os grupos Experimento (pré e pós) (TABELAS 5a, 5b, 5c e 5d). 
TABELA 5a: Teste de Mann-Whitney para comparação da auto-avaliação de conhecimentos sobre conceitos de TP X TT.

\begin{tabular}{|c|c|c|c|c|}
\hline \multirow{2}{*}{ Conceitos } & \multicolumn{3}{|c|}{ TURISMO (TT) X PEDAGOGIA (TP) } \\
\cline { 2 - 5 } & \multicolumn{2}{|c|}{ CONTROLE } & \multicolumn{2}{c|}{ EXPERIMENTAL } \\
\cline { 2 - 5 } & PRÉ & POS & 1,000 & 0,0 POS \\
\hline Mata Atlântica & 0,969 & 0,684 & 0,727 & 0,045 \\
\hline Meio Ambiente & 0,936 & 0,707 & 0,740 & 0,883 \\
\hline Cavernas & 0,952 & 0,941 & 0,826 & 0,967 \\
\hline Unidade de Conservação & 0,798 & 0,559 & 0,721 & 0,830 \\
\hline Educação Ambiental & 0,913 & 0,651 & 0,753 & 0,896 \\
\hline
\end{tabular}

TABELA 5b: Teste de Mann-Whitney para comparação dos sentimentos de TP e TT.

\begin{tabular}{|c|c|c|c|c|}
\hline \multirow{3}{*}{ Sentimento } & \multicolumn{4}{|c|}{ TURISMO (TT) X PEDAGOGIA (TP) } \\
\hline & \multicolumn{2}{|c|}{ CONTROLE } & \multicolumn{2}{|c|}{ EXPERIMENTAL } \\
\hline & PRÉ & PÓS & PRE & POS \\
\hline alerta/sonolento & 0,544 & 0,015 & 0,001 & 0,001 \\
\hline calmo/agitado & 0,178 & 0,265 & 0,620 & 0,062 \\
\hline com idéias claras/confuso & 0,646 & 0,868 & 0,372 & 0,306 \\
\hline satisfeito/insatisfeito & 0,060 & 0,868 & 0,001 & 0,070 \\
\hline tranqüilo/preocupado & 0,739 & 0,997 & 0,150 & 0,216 \\
\hline atento/distraído & 0,194 & 0,362 & 0,106 & 0,192 \\
\hline alegre/triste & 0,235 & 0,051 & 0,190 & 0,227 \\
\hline interessado/desinteressado & 0,378 & 0,575 & 0,022 & 0,026 \\
\hline seguro/inseguro & 0,544 & 0,052 & 0,046 & 0,218 \\
\hline solitário/integrado & 0,507 & 0,801 & 0,077 & 0,084 \\
\hline confiante/temeroso & 0,265 & 0,249 & 0,614 & 0,543 \\
\hline
\end{tabular}


TABELA 5c: Teste de Mann-Whitney para comparação das atitudes de TP e TT.

\begin{tabular}{|c|c|c|c|c|}
\hline \multirow{3}{*}{ Atitude } & \multicolumn{4}{|c|}{ TURISMO (TT) X PEDAGOGIA (TP) } \\
\hline & \multicolumn{2}{|c|}{ CONTROLE } & \multicolumn{2}{|c|}{ EXPERIMENTAL } \\
\hline & PRÉ & PÓS & PRE & POS \\
\hline Participar do movimento ambientalista & 0,671 & 0,532 & 0,955 & 0,889 \\
\hline Mudar seus hábitos de consumo & 0,897 & 0,777 & 0,567 & 0,901 \\
\hline Visitar áreas naturais & 0,744 & 0,552 & 0,492 & 0,637 \\
\hline Usar menos o carro & 0,919 & 0,978 & 0,833 & 0,848 \\
\hline Divulgar a preservação ambiental & 0,665 & 0,483 & 0,657 & 0,828 \\
\hline Fazer cursos na área ambiental & 0,869 & 0,517 & 0,734 & 0,869 \\
\hline Pesquisar e escrever artigos de Meio Ambiente & 0,803 & 0,569 & 0,935 & 0,895 \\
\hline $\begin{array}{l}\text { Rever seus hábitos cotidianos de modo a } \\
\text { economizar recursos }\end{array}$ & 0,760 & 0,819 & 0,695 & 0,877 \\
\hline $\begin{array}{l}\text { Ler a respeito ou assistir documentários sobre } \\
\text { meio ambiente }\end{array}$ & 0,891 & 0,503 & 0,663 & 0,835 \\
\hline Ser mais integrado às outras pessoas & 0,992 & 0,497 & 0,759 & 0,693 \\
\hline Espiritualizar-se & 0,734 & 0,650 & 0,595 & 0,876 \\
\hline Cuidar de plantas e animais & 0,760 & 0,512 & 0,734 & 0,742 \\
\hline Reciclar o lixo & 0,975 & 0,497 & 0,983 & 0,660 \\
\hline Filiar-se à uma ONG ambientalista & 0,611 & 0,497 & 0,928 & 0,810 \\
\hline $\begin{array}{c}\text { Doar recursos ou trabalhar voluntariamente } \\
\text { para a Conservação Ambiental }\end{array}$ & 0,611 & 0,488 & 0,942 & 0,835 \\
\hline $\begin{array}{l}\text { Pagar mais impostos, desde que os mesmos } \\
\text { sejam revertidos em Conservação Ambiental }\end{array}$ & 0,744 & 0,707 & 0,948 & 0,703 \\
\hline
\end{tabular}

TABELA 5d: Teste de Mann-Whitney para comparação dos valores de TP e TT.

\begin{tabular}{|c|c|c|c|c|}
\hline \multirow{3}{*}{ Valores } & \multicolumn{4}{|c|}{ TURISMO (TT) X PEDAGOGIA (TP) } \\
\hline & \multicolumn{2}{|c|}{ CONTROLE } & \multicolumn{2}{|c|}{ EXPERIMENTAL } \\
\hline & PRÉ & PÓS & PRE & POS \\
\hline $\begin{array}{c}\text { O que você acha da relação dos animais da } \\
\text { mata com o homem? Ruins/bons }\end{array}$ & 0,001 & 0,008 & 0,097 & 0,208 \\
\hline $\begin{array}{l}\text { O que você sente quando ouve falar sobre a } \\
\text { extinção de plantas e animais? Não posso } \\
\text { fazer nada/Posso fazer muito }\end{array}$ & 0,869 & 0,403 & 0,976 & 0,961 \\
\hline $\begin{array}{l}\text { Ao entrar em uma mata você fica: Com } \\
\text { medo/Muito animado }\end{array}$ & 0,825 & 0,478 & 0,620 & 0,653 \\
\hline $\begin{array}{l}\text { O que você sente sobre a caça e a venda de } \\
\text { animais silvestres? Concordo totalmente/ } \\
\text { Discordo totalmente }\end{array}$ & 0,732 & 0,648 & 0,772 & 0,887 \\
\hline $\begin{array}{c}\text { O que você sente quando vê áreas de mata } \\
\text { queimando? Feliz/Triste }\end{array}$ & 0,753 & 0,536 & 0,516 & 0,941 \\
\hline $\begin{array}{c}\text { Garantir a preservação de uma espécie é } \\
\text { garantir a preservação da mata. } \\
\text { Concordo/Discordo }\end{array}$ & 0,749 & 0,502 & 1,000 & 0,158 \\
\hline $\begin{array}{l}\text { Ao entra numa caverna de calcário você fica: } \\
\text { Com medo/Muito animado }\end{array}$ & 0,156 & 0,431 & 0,162 & 0,596 \\
\hline $\begin{array}{l}\text { O modo de vida das populações tradicionais } \\
\text { deve ser mantido. Não Concordo/Concordo }\end{array}$ & 0,209 & 0,991 & 0,517 & 0,690 \\
\hline Visitar áreas naturais é: Incômodo/Agadável & 0,706 & 0,616 & 0,516 & 0,606 \\
\hline $\begin{array}{c}\text { A preservação da Mata Atlântica: } \\
\text { É urgente/Não é urgente } \\
\end{array}$ & 0,753 & 0,706 & 0,563 & 0,647 \\
\hline $\begin{array}{l}\text { Quando estou em contato direto com a } \\
\text { Natureza eu me sinto: Isolado/Integrado }\end{array}$ & 0,980 & 0,522 & 0,563 & 0,546 \\
\hline $\begin{array}{l}\text { A natureza ensina ao ser humano como ele } \\
\text { deve viver: Não concordo/Concordo }\end{array}$ & 0,958 & 0,517 & 0,526 & 0,669 \\
\hline $\begin{array}{l}\text { Os ambientalistas são pessoas que deveriam } \\
\text { pensar mais no desenvolvimento da sociedade. } \\
\text { Não concordo/Concordo }\end{array}$ & 0,044 & 0,165 & 0,028 & 0,070 \\
\hline
\end{tabular}


Controle x Experimental nos períodos pré e pós-experimento

Em seguida, considera-se a comparação dos grupos controle e experimental entre si, tanto antes quanto após a intervenção. Por se tratar da comparação de dois grupos independentes, será utilizado o teste não paramétrico de Mann-Whitney. Os resultados estão indicados nas TABELAS 6a, 6b e 6c.

TABELA 6a:Teste de Mann-Whitney para comparação da auto-avaliação de conhecimentos sobre conceitos dos grupos Controle X Experimental, em cada uma das turmas e das medidas.

\begin{tabular}{|c|c|c|c|c|}
\hline \multirow{2}{*}{ Conceito } & \multicolumn{3}{|c|}{ CONTROLE X EXPERIMENTAL } \\
\cline { 2 - 5 } & \multicolumn{2}{|c|}{ TURISMO (TT) } & \multicolumn{2}{|c|}{ PEDAGOGIA (TP) } \\
\cline { 2 - 5 } & PRÉ & PÓS & \multicolumn{2}{|c|}{ PRE } \\
\hline Mata Atlântica & 0,864 & 0,049 & 0,014 \\
\hline Meio Ambiente & 0,558 & 0,990 & 0,016 \\
\hline Cavernas & 0,204 & 0,001 & 0,271 & 0,001 \\
\hline Unidade de Conservação & 0,367 & 0,132 & 0,396 & 0,035 \\
\hline Educação Ambiental & 0,530 & 0,048 & 0,826 & 0,018 \\
\hline Comunidades Tradicionais & 0,577 & 0,002 & 0,446 & 0,003 \\
\hline
\end{tabular}

TABELA 6b:Teste de Mann-W hitney para comparação das atitudes dos grupos Controle X Experimental, em cada uma das turmas e das medidas.

\begin{tabular}{|c|c|c|c|c|}
\hline \multirow{3}{*}{ Atitude } & \multicolumn{4}{|c|}{ CONTROLE X EXPERIMENTAL } \\
\hline & \multicolumn{2}{|c|}{ TURISMO (TT) } & \multicolumn{2}{|c|}{ PEDAGOGIA (TP) } \\
\hline & PRÉ & PÓS & PRE & POS \\
\hline Participar do movimento ambientalista & 0,016 & 0,026 & 0,042 & 0,008 \\
\hline Mudar seus hábitos de consumo & 0,646 & 0,012 & 0,928 & 0,009 \\
\hline Visitar áreas naturais & 0,626 & 0,000 & 0,461 & 0,000 \\
\hline Usar menos o carro & 0,406 & 0,036 & 0,441 & 0,032 \\
\hline Divulgar a preservação ambiental & 0,090 & 0,001 & 0,064 & 0,000 \\
\hline Fazer cursos na área ambiental & 0,148 & 0,012 & 0,090 & 0,006 \\
\hline Pesquisar e escrever artigos Meio Ambiente & 0,109 & 0,105 & 0,088 & 0,083 \\
\hline $\begin{array}{c}\text { Rever seus hábitos cotidianos de modo a } \\
\text { economizar recursos }\end{array}$ & 0,734 & 0,001 & 0,948 & 0,001 \\
\hline $\begin{array}{l}\text { Ler a respeito ou assistir documentários sobre } \\
\text { meio ambiente }\end{array}$ & 0,059 & 0,050 & 0,030 & 0,016 \\
\hline Ser mais integrado às outras pessoas & 0,060 & 0,000 & 0,097 & 0,000 \\
\hline Espiritualizar-se & 0,708 & 0,048 & 0,639 & 0,027 \\
\hline Cuidar de plantas e animais & 0,044 & 0,079 & 0,044 & 0,016 \\
\hline Reciclar o lixo & 0,334 & 0,000 & 0,319 & 0,000 \\
\hline Filiar-se à uma ONG ambientalista & 0,028 & 0,017 & 0,059 & 0,004 \\
\hline $\begin{array}{l}\text { Doar recursos ou trabalhar voluntariamente para a } \\
\text { Conservação Ambiental }\end{array}$ & 0,020 & 0,002 & 0,077 & 0,000 \\
\hline $\begin{array}{l}\text { Pagar mais impostos, desde que os mesmos } \\
\text { sejam revertidos para Conservação Ambiental }\end{array}$ & 0,425 & 0,010 & 0,211 & 0,040 \\
\hline
\end{tabular}


TABELA 6c:Teste de Mann-Whitney para comparação dos valores dos grupos Controle $\mathrm{X}$

Experimental, em cada uma das turmas e das medidas.

\begin{tabular}{|c|c|c|c|c|}
\hline \multirow{3}{*}{ Valores } & \multicolumn{4}{|c|}{ CONTROLE X EXPERIMENTAL } \\
\hline & \multicolumn{2}{|c|}{ TURISMO (TT) } & \multicolumn{2}{|c|}{ PEDAGOGIA (TP) } \\
\hline & PRÉ & PÓS & PRE & POS \\
\hline $\begin{array}{l}\text { O que você acha da relação dos animais da } \\
\text { mata com o homem? Ruins/bons }\end{array}$ & 0,042 & 0,000 & 0,094 & 0,001 \\
\hline $\begin{array}{c}\text { O que você sente quando ouve falar sobre a } \\
\text { extinção de plantas e animais? Não posso fazer } \\
\text { nada/Posso fazer muito }\end{array}$ & 0,521 & 0,023 & 0,651 & 0,005 \\
\hline $\begin{array}{c}\text { Ao entrar em uma mata você fica: Com } \\
\text { medo/Muito animado }\end{array}$ & 0,798 & 0,000 & 0,561 & 0,000 \\
\hline $\begin{array}{l}\text { O que você sente sobre a caça e a venda de } \\
\text { animais silvestres? Concordo totalmente/ } \\
\text { Discordo totalmente }\end{array}$ & 0,078 & 0,000 & 0,073 & 0,000 \\
\hline $\begin{array}{l}\text { O que você sente quando vê áreas de mata } \\
\text { queimando? Feliz/Triste }\end{array}$ & 0,033 & 0,000 & 0,012 & 0,000 \\
\hline $\begin{array}{c}\text { Garantir a preservação de uma espécie é } \\
\text { garantir a preservação da mata. } \\
\text { Concordo/Discordo }\end{array}$ & 0,206 & 0,001 & 0,353 & 0,000 \\
\hline $\begin{array}{l}\text { Ao entra numa caverna de calcário você fica: } \\
\text { Com medo/Muito animado }\end{array}$ & 0,262 & 0,000 & 0,140 & 0,000 \\
\hline $\begin{array}{l}\text { O modo de vida das populações tradicionais } \\
\text { deve ser mantido. Não Concordo/Concordo }\end{array}$ & 0,099 & 0,000 & 0,840 & 0,000 \\
\hline Visitar áreas naturais é: Incômodo/Agadável & 0,119 & 0,000 & 0,061 & 0,000 \\
\hline $\begin{array}{c}\text { A preservação da Mata Atlântica: } \\
\text { É urgente/Não é urgente }\end{array}$ & 0,053 & 0,000 & 0,022 & 0,000 \\
\hline $\begin{array}{c}\text { Quando estou em contato direto com a Natureza } \\
\text { eu me sinto: Isolado/Integrado }\end{array}$ & 0,292 & 0,000 & 0,073 & 0,000 \\
\hline $\begin{array}{l}\text { A natureza ensina ao ser humano como ele } \\
\text { deve viver: Não concordo/Concordo }\end{array}$ & 0,095 & 0,001 & 0,027 & 0,000 \\
\hline $\begin{array}{l}\text { Os ambientalistas são pessoas que deveriam } \\
\text { pensar mais no desenvolvimento da sociedade. } \\
\text { Não concordo/Concordo }\end{array}$ & 0,986 & 0,079 & 0,608 & 0,079 \\
\hline
\end{tabular}

As diferenças entre controle e experimental para os sentimentos são indicadas na TABELA 7.

TABELA 7:Teste de Mann-Whitney para comparação das variações de sentimentos dos grupos Controle X Experimental, em cada uma das turmas e das medidas.

\begin{tabular}{|c|c|c|c|c|}
\hline \multirow{3}{*}{ Valores } & \multicolumn{4}{|c|}{ CONTROLE X EXPERIMENTAL } \\
\hline & \multicolumn{2}{|c|}{ TURISMO (TT) } & \multicolumn{2}{|c|}{ PEDAGOGIA (TP) } \\
\hline & PRÉ & PÓS & PRE & POS \\
\hline alerta/sonolento & 0,034 & 0,772 & 0,033 & 0,045 \\
\hline calmo/agitado & 0,975 & 0,499 & 0,336 & 0,382 \\
\hline com idéias claras/confuso & 0,804 & 0,119 & 0,377 & 0,506 \\
\hline satisfeito/insatisfeito & 0,028 & 0,693 & 0,813 & 0,030 \\
\hline tranqüilo/preocupado & 0,386 & 0,318 & 0,263 & 0,691 \\
\hline atento/distraído & 0,925 & 0,652 & 1,000 & 0,786 \\
\hline alegre/triste & 0,836 & 0,886 & 0,969 & 0,285 \\
\hline interessado/desinteressado & 0,120 & 0,980 & 0,773 & 0,142 \\
\hline seguro/inseguro & 0,401 & 0,017 & 0,037 & 0,533 \\
\hline solitário/integrado & 0,913 & 0,081 & 0,253 & 0,716 \\
\hline confiante/temeroso & 0,512 & 0,842 & 0,976 & 0,767 \\
\hline
\end{tabular}


Pré x Pós no caso da condição controle e da condição experimental

Em cada turma de alunos (TP e TT) serão comparados agora os resultados pré e pós-intervenção no grupo experimento e no grupo controle. Como a análise dos dados foi feita através de técnicas não paramétricas, que se baseiam nas medidas de mediana e demais percentis, os gráficos de médias e desvios padrão foram substituídos por boxplots, gráficos construídos com base na mediana, primeiro e terceiro quartis, e valores mínimo e máximo (Anexo 2).

Construiu-se os gráficos que representam a média mais ou menos duas vezes o erro padrão da média (o que corresponde a um intervalo de $95 \%$ de confiança para a média) para as respostas em cada variável, de acordo com a medida (pré ou pós) e grupo (controle ou experimental), separadamente para cada turma de alunos (TT ou TP). Esta apresentação não tem efeito estatístico, no entanto, optou-se por organizar os dados dessa forma apenas para evidenciar visualmente as tendências dos resultados e as possíveis mudanças produzidas (Anexo 3).

Em todas as análises seguintes, foi utilizado o Teste não paramétrico de Wilcoxon para comparação de dois grupos dependentes (ou pareados) com relação a uma variável quantitativa. Nas próximas análises considerou-se o nível de significância de $5 \%(p<0,050)$. Resultados significativos para a comparação de resultados pré e pós intervenção foram destacados em negrito.

As diferenças entre pré e pós-teste só não foram significativas para os conhecimentos "Meio Ambiente" ( $p=0,101)$ e "Educação Ambiental" $(p=0,136) d a$ TT, sendo significativo $(p<0,05)$ para todos os demais conhecimentos da TT e da TP. 
TABELA 8: Diferenças estatísticas referentes à "auto-avaliação de conhecimentos" nos Pré e Pós-Testes.

\begin{tabular}{|c|c|c|c|c|c|c|c|c|}
\hline \multirow{2}{*}{ Conhecimentos } & \multicolumn{8}{|c|}{ GRUPOS (análise Pós X Pré) } \\
\cline { 2 - 10 } & \multicolumn{2}{|c|}{$\begin{array}{c}\text { TT } \\
\text { Controle }\end{array}$} & \multicolumn{2}{c|}{$\begin{array}{c}\text { TT } \\
\text { Experimental }\end{array}$} & \multicolumn{2}{c|}{$\begin{array}{c}\text { Controle } \\
\text { Experimental }\end{array}$} \\
\cline { 2 - 10 } & $\mathrm{Z}$ & Valor $\mathrm{p}$ & $\mathrm{Z}$ & Valor $\mathrm{p}$ & $\mathrm{Z}$ & Valor $\mathrm{p}$ & $\mathrm{Z}$ & Valor $\mathrm{p}$ \\
\hline Mata Atlântica &,- 156 &, 883 & $-2,804$ &, 004 &,- 337 &, 745 & $-2,059$ &, 039 \\
\hline Meio Ambiente & $-1,195$ &, 239 & $-1,651$ &, 101 &,- 749 &, 464 & $-2,732$ &, 005 \\
\hline Cavernas de Calcário & $-1,010$ &, 324 & $-4,190$ & 000 & $-1,423$ &, 159 & $-4,158$ &, 000 \\
\hline Unidades de Conservação & $-1,016$ &, 318 & $-2,403$ & 015 & $-1,009$ &, 321 & $-2,099$ &, 035 \\
\hline Educação Ambiental & $-1,246$ &, 219 & $-1,502$ &, 136 &, 000 & 1,000 & $-2,247$ &, 023 \\
\hline Comunidades Tradicionais & $-1,372$ &, 175 & $-3,039$ & 002 &,- 673 &, 511 & $-2,573$ &, 008 \\
\hline
\end{tabular}

Com relação a mudanças de sentimentos, no entanto, os resultados obtidos não foram tão significativos, diferentemente do obtido por Alvarenga e Nogueira-Filho (2005). Aqui, também foi utilizada em todas as análises o Teste não paramétrico de Wilcoxon com nível de significância de 5\%. Resultados significativos para a comparação de resultados pré e pós intervenção foram destacados na células em negrito (TABELA 9).

TABELA 9: Diferenças estatísticas referentes a "sentimentos" nos Pré e Pós-Testes.

\begin{tabular}{|c|c|c|c|c|c|c|c|c|}
\hline \multirow{2}{*}{ Sentimentos } & \multicolumn{9}{|c|}{ GRUPOS (análise Pós X Pré) } \\
\cline { 2 - 10 } & \multicolumn{2}{c}{$\begin{array}{c}\text { TT } \\
\text { Controle }\end{array}$} & \multicolumn{2}{c|}{$\begin{array}{c}\text { TT } \\
\text { Experimental }\end{array}$} & \multicolumn{2}{c|}{$\begin{array}{c}\text { Tontrole } \\
\text { Coxp }\end{array}$} & \multicolumn{2}{c|}{ Experimental } \\
\cline { 2 - 10 } & $\mathrm{Z}$ & Valor $p$ & $\mathrm{Z}$ & Valor $\mathrm{p}$ & $\mathrm{Z}$ & Valor $\mathrm{p}$ & $\mathrm{Z}$ & Valor $p$ \\
\hline alerta/sonolento & $-2,679$ &, 007 & $-3,340$ &, 000 &,- 661 &, 519 & $-3,350$ &, 000 \\
\hline calmo/agitado & $-1,370$ &, 171 &,- 817 &, 423 & $-1,466$ &, 146 & $-1,453$ &, 150 \\
\hline com idéias claras/confuso &,- 279 &, 780 & $-1,016$ &, 318 &,- 713 &, 487 & $-1,507$ &, 135 \\
\hline satisfeito/insatisfeito &,- 888 &, 374 & $-2,859$ &, 003 & $-1,009$ &, 321 & $-2,490$ &, 011 \\
\hline tranqüilo/preocupado &,- 252 &, 801 &,- 851 &, 405 &,- 127 &, 906 &,- 814 &, 426 \\
\hline atento/distraído &,- 456 &, 648 & $-1,372$ &, 175 & $-1,613$ &, 109 & $-1,472$ &, 145 \\
\hline alegre/triste &,- 659 &, 510 & $-1,790$ &, 074 & $-1,742$ &, 083 & $-1,529$ &, 130 \\
\hline interessado/desinteressado &,- 813 &, 416 & $-2,551$ &, 009 & $-1,021$ &, 315 & $-2,403$ &, 014 \\
\hline seguro/inseguro & $-2,488$ &, 013 &,- 865 &, 396 &,- 997 &, 327 & $-2,638$ &, 007 \\
\hline solitário/integrado &,- 486 &, 627 & $-1,890$ &, 059 &,- 601 &, 558 & $-1,526$ &, 131 \\
\hline confiante/temeroso &,- 969 &, 333 & $-3,340$ &, 000 &,- 813 &, 426 &,- 601 &, 559 \\
\hline
\end{tabular}


Os alunos da TT que realizaram a viagem e participaram das atividades dirigidas mostraram diferenças maiores para os sentimentos alerta/sonolentos, satisfeito/insatisfeito, interessado/desinteresado e confiante/temeroso, significando que estavam mais alertas $(p=0,000)$, mais satisfeitos $(p=0,003)$, mais interessados $(p=0,009)$ e mais confiantes $(p=0,000)$. Os alunos da TP apresentaram mudanças significativas para os sentimentos alerta/sonolentos, satisfeito/insatisfeito, interessado/desinteresado e seguro/inseguro (mais alertas: $p=0,000$; mais satisfeitos: $p=0,011$; mais interessados: $p=0,014$; e mais seguros: $p=0,007$ ). Para os demais sentimentos não houve mudanças significativas. 
Análise das mudanças de valores

Os resultados mostraram mudanças significativas entre o pré e o pósteste $(p<0,050)$ para todos os valores avaliados na TT, e para a grande maioria deles para a TP (TABELA 10).

TABELA 10: Diferenças estatísticas referentes a "valores" nos Pré e Pós-Testes.

\begin{tabular}{|c|c|c|c|c|c|c|c|c|}
\hline \multirow{3}{*}{ Valores } & \multicolumn{8}{|c|}{ GRUPOS (análise Pós X Pré) } \\
\hline & \multicolumn{2}{|c|}{$\begin{array}{c}\text { TT } \\
\text { Controle }\end{array}$} & \multicolumn{2}{|c|}{$\begin{array}{c}\text { TT } \\
\text { Experimental }\end{array}$} & \multicolumn{2}{|c|}{$\begin{array}{c}\text { TP } \\
\text { Controle }\end{array}$} & \multicolumn{2}{|c|}{$\begin{array}{c}\text { TP } \\
\text { Experimental }\end{array}$} \\
\hline & $\mathrm{Z}$ & Valor $p$ & $\mathrm{Z}$ & Valor $p$ & $\mathrm{Z}$ & Valor $p$ & $\mathrm{Z}$ & Valor $p$ \\
\hline $\begin{array}{l}\text { O que você acha da relação dos } \\
\text { animais da mata com o homem? } \\
\text { Ruins/bons }\end{array}$ & $-1,131$ & ,272 & $-2,426$ & ,014 &,- 660 &, 519 & $-1,736$ & ,085 \\
\hline $\begin{array}{c}\text { O que você sente quando ouve falar } \\
\text { sobre a extinção de plantas e } \\
\text { animais? Não posso fazer } \\
\text { nada/Posso fazer muito }\end{array}$ &,- 515 & ,618 & $-3,132$ & 001 & $-1,034$ &, 310 & $-1,494$ & 139 \\
\hline $\begin{array}{l}\text { Ao entrar em uma mata você fica: } \\
\text { Com medo/Muito animado }\end{array}$ &,- 013 & ,995 & $-4,556$ &, 000 &,- 036 & ,976 & $-3,889$ &, 000 \\
\hline $\begin{array}{l}\text { O que você sente sobre a caça e a } \\
\text { venda de animais silvestres? } \\
\text { Concordo totalmente/ Discordo } \\
\text { totalmente }\end{array}$ & $-1,500$ &, 137 & $-4,060$ &, 000 &,- 795 & ,436 & $-3,503$ &, 000 \\
\hline $\begin{array}{l}\text { O que você sente quando vê áreas } \\
\text { de mata queimando? Feliz/Triste }\end{array}$ & $-3,130$ & ,001 & $-3,950$ &, 000 & $-1,629$ &, 105 & $-3,402$ &, 000 \\
\hline $\begin{array}{l}\text { Garantir a preservação de uma } \\
\text { espécie é garantir a preservação da } \\
\text { mata. Concordo/Discordo }\end{array}$ &,- 830 & ,418 & $-3,293$ &, 001 &,- 807 & ,430 & $-3,432$ & ,000 \\
\hline $\begin{array}{l}\text { Ao entra numa caverna de calcário } \\
\text { você fica: Com medo/Muito } \\
\text { animado }\end{array}$ &,- 418 & ,686 & $-4,192$ &, 000 &,- 481 & ,640 & $-3,782$ & ,000 \\
\hline $\begin{array}{l}\text { O modo de vida das populações } \\
\text { tradicionais deve ser mantido. Não } \\
\text { Concordo/Concordo }\end{array}$ & $-1,158$ & ,255 & $-4,158$ &, 000 &,- 686 & ,503 & $-3,660$ & ,000 \\
\hline $\begin{array}{l}\text { Visitar áreas naturais é: } \\
\text { Incômodo/Agadável }\end{array}$ & $-2,593$ & ,008 & $-4,638$ &, 000 &,- 096 & ,929 & $-3,865$ & ,000 \\
\hline $\begin{array}{l}\text { A preservação da Mata Atlântica: } \\
\text { É urgente/Não é urgente }\end{array}$ & $-2,486$ & ,011 & $-4,632$ & ,000 & $-1,182$ & ,243 & $-4,132$ & ,000 \\
\hline $\begin{array}{l}\text { Quando estou em contato direto } \\
\text { com a Natureza eu me sinto: } \\
\text { Isolado/Integrado }\end{array}$ & $-2,811$ & ,004 & $-4,117$ & ,000 & $-1,512$ & ,134 & $-3,444$ & ,000 \\
\hline $\begin{array}{l}\text { A natureza ensina ao ser humano } \\
\text { como ele deve viver: Não } \\
\text { concordo/Concordo }\end{array}$ &,- 076 & ,946 & $-4,460$ & ,000 & $-1,103$ & ,278 & $-3,298$ & ,000 \\
\hline $\begin{array}{l}\text { Os ambientalistas são pessoas que } \\
\text { deveriam pensar mais no } \\
\text { desenvolvimento da sociedade. Não } \\
\text { concordo/Concordo }\end{array}$ &,- 511 & ,620 & $-2,574$ & ,009 &,- 649 & ,530 & $-2,005$ & ,044 \\
\hline
\end{tabular}

\section{Análise das mudanças de atitudes}

Com relação às atitudes não há exceções: todas as que foram testadas apontaram para diferenças no Teste de Wilcoxon abaixo do nível de significância de 5\% entre Pré e Pós-Teste (TABELA 11). 
TABELA 11: Diferenças estatísticas referentes a "atitudes" nos Pré e Pós-Testes.

\begin{tabular}{|c|c|c|c|c|c|c|c|c|}
\hline \multirow{3}{*}{ A titudes Pró-A mbiente } & \multicolumn{8}{|c|}{ GRUPOS (análise Pós X Pré) } \\
\hline & \multicolumn{2}{|c|}{$\begin{array}{c}\mathrm{TT} \\
\text { Controle }\end{array}$} & \multicolumn{2}{|c|}{$\begin{array}{c}\text { TT } \\
\text { Experimental }\end{array}$} & \multicolumn{2}{|c|}{$\begin{array}{c}\text { TP } \\
\text { Controle }\end{array}$} & \multicolumn{2}{|c|}{$\begin{array}{c}\mathrm{TP} \\
\text { Experimental }\end{array}$} \\
\hline & $\mathrm{Z}$ & Valor $p$ & $\mathrm{Z}$ & Valor $p$ & $\mathrm{Z}$ & $\begin{array}{c}\text { Valor } \\
p\end{array}$ & $\mathrm{Z}$ & Valor $p$ \\
\hline $\begin{array}{c}\text { Participar do movimento } \\
\text { ambientalista }\end{array}$ &,- 501 & 627 & $-4,061$ & ,000 &,- 637 &, 534 & $-2,773$ &, 004 \\
\hline Mudar seus hábitos de consumo &,- 840 & ,411 & $-3,076$ &, 001 &,- 433 & 675 & $-2,477$ & 012 \\
\hline Visitar áreas naturais & $-2,289$ & 021 & $-4,414$ &, 000 & $-1,183$ & 244 & $-3,621$ &, 000 \\
\hline Usar menos o carro & $-1,314$ & , 195 & $-2,654$ & ,007 &,- 793 & ,437 & $-1,952$ & 050 \\
\hline Divulgar a preservação ambiental & $-2,330$ & 018 & $-3,432$ &, 000 & $-2,363$ & 017 & $-2,395$ & 015 \\
\hline Fazer cursos na área ambiental &,- 283 & ,786 & $-3,554$ &, 000 &,- 613 &, 550 & $-2,843$ &, 003 \\
\hline $\begin{array}{l}\text { Pesquisar e escrever artigos sobre } \\
\text { Meio Ambiente }\end{array}$ & $-1,050$ & ,302 & $-3,508$ &, 000 &,- 589 &, 566 & $-2,261$ & 022 \\
\hline $\begin{array}{l}\text { Rever seus hábitos cotidianos de } \\
\text { modo a economizar recursos }\end{array}$ & $-2,201$ & ,026 & $-2,127$ & ,032 & $-1,664$ & ,098 & $-1,951$ & 050 \\
\hline $\begin{array}{c}\text { Ler a respeito ou assistir } \\
\text { documentários sobre meio ambiente }\end{array}$ & $-1,804$ & ,072 & $-2,005$ &, 044 & $-2,058$ &, 039 & $-2,087$ &, 036 \\
\hline $\begin{array}{c}\text { Ser mais integrado às outras } \\
\text { pessoas }\end{array}$ & $-2,230$ &, 024 & $-3,943$ &, 000 &,- 949 &, 351 & $-2,987$ &, 002 \\
\hline Espiritualizar-se &,- 502 & 627 & $-3,054$ & ,002 &,- 152 &, 886 & $-2,314$ & 019 \\
\hline Cuidar de plantas e animais &,- 027 & ,984 & $-3,498$ &, 000 &,- 202 & ,848 & $-2,422$ & 014 \\
\hline Reciclar o lixo &,- 259 & 805 & $-4,079$ &, 000 & $-2,181$ &, 028 & $-3,904$ &, 000 \\
\hline Filiar-se à uma ONG ambientalista &,- 343 & ,740 & $-3,827$ & , 000 &,- 469 & 649 & $-3,378$ & 000 \\
\hline $\begin{array}{c}\text { Doar recursos ou trabalhar } \\
\text { voluntariamente para a } \\
\text { Conservação Ambiental } \\
\end{array}$ &,- 942 & ,356 & $-4,249$ & , 000 &,- 577 &, 574 & $-3,243$ & ,001 \\
\hline $\begin{array}{l}\text { Pagar mais impostos, desde que os } \\
\text { mesmos sejam revertidos para } \\
\text { Conservação Ambiental }\end{array}$ &,- 927 & ,363 & $-3,749$ &, 000 & $-1,093$ & ,282 & $-2,258$ & ,022 \\
\hline
\end{tabular}

\section{Validade interna e externa}

O questionário pode ser desenhado de forma a ameaçar os resultados do estudo, mas ele também pode ser avaliado. A análise de consistência interna por meio da divisão do questionário em duas partes é um passo da análise de sua confiabilidade. Nesse caso, utiliza-se o coeficiente Alpha de Cronbach.

Primeiramente, considerando que a escala consiste de 62 itens, que estão completamente respondidos por 229 indivíduos, tem-se que a consistência interna da escala é 0,872 (TABELA 12). O valor máximo que o coeficiente pode assumir é 1 , e valores maiores que 0,75 são considerados altos. Portanto, conclui-se que a consistência da escala é satisfatória ${ }^{8}$.

\footnotetext{
${ }^{8} \mathrm{O}$ teste de consistência já inclui o questionário utilizado mais adiante, no Estudo 3b.
} 
TABELA 12: Teste de Confiabilidade do questionário.

\begin{tabular}{|c|c|}
\hline Coeficiente Alpha de Cronbach & № de Itens \\
\hline 0,872 & 62 \\
\hline
\end{tabular}

Para uma análise mais detalhada, pode avaliar cada uma das partes do questionário independentemente (TABELA 13), após a divisão da escala em duas partes (itens pares e ímpares):

TABELA 13: Teste de Confiabilidade das partes do questionário.

\begin{tabular}{|l|l|l|r|}
\hline \multirow{4}{*}{$\begin{array}{l}\text { Coeficiente } \\
\text { Alpha de } \\
\text { Cronbach }\end{array}$} & Parte 1 & Valor & 0,814 \\
\cline { 2 - 3 } & & № de Itens & 31 \\
\cline { 2 - 3 } & Parte 2 & Valor & 0,785 \\
\cline { 2 - 3 } & & № de Itens & 31 \\
\hline \multicolumn{2}{|l|}{ Correlação de Pearson } & 62 \\
\hline \multicolumn{2}{|l|}{ Coeficiente de Spearman-Brown } & 0,618 \\
\hline \multicolumn{2}{|l|}{ Coeficiente de Guttman Split-Half } & 0,764 \\
\hline
\end{tabular}

O coeficiente Alpha de Cronbach é maior que 0,75 nas duas partes, o que indica que há consistência entre os itens da escala. São apresentadas três medidas da correlação entre as respostas das duas partes: correlação de Pearson, coeficiente de Spearman-Brown, coeficiente de Guttman. Todos indicam que há uma correlação positiva entre as duas partes, ou seja, valores altos na primeira parte estão associados a valores altos na segunda parte. E essa correlação é considerada moderadamente alta, o que é esperado. Se há correlação é muito alta, próxima de 1, poderíamos suspeitar que os itens estão medindo a mesma coisa, e assim alguns deles poderiam ser excluídos. O ideal é que os itens meçam diferentes aspectos de uma mesma característica, e por isso devem ser concordantes, mas não idênticos.

A TABELA 14 abaixo apresenta as estatísticas descritivas (média, variância, desvio padrão e número de itens) de cada parte e também da escala total.

TABELA 14: Estatísticas Descritivas.

\begin{tabular}{|l|c|c|c|c|}
\hline & Média & Variância & Desvio Padrão & № de Itens \\
\hline Parte1 & 1702,61 & 83088,458 & 288,251 & 31 \\
\hline Parte 2 & 1045,03 & 31415,117 & 177,243 & 31 \\
\hline Ambas as Partes & 2747,64 & 177641,740 & 421,476 & 62 \\
\hline
\end{tabular}

Abaixo, pode ser avaliada a influência de cada item na escala total. Se acima (TABELA 12) temos as descritivas da escala total, que apresenta um 
Alpha $=0,872$ a TABELA 15 apresenta a descrição da escala com um item a menos, para cada item. Se o Alpha aumentasse ou diminuísse consideravelmente com a exclusão de um item, deveríamos considerar a alteração desse item, porém não se observa nenhuma alteração considerável nos resultados abaixo.

\begin{tabular}{|c|c|c|c|c|}
\hline \multicolumn{5}{|c|}{ TABELA 15: Estatística para o total dos itens. } \\
\hline & Média & Variância & $\begin{array}{c}\text { Correlação } \\
\text { entre o } \\
\text { item- escala }\end{array}$ & $\begin{array}{c}\text { Coeficiente } \\
\text { Alfa de } \\
\text { Cronbach }\end{array}$ \\
\hline Escala total & 2747,64 & 177641,740 & --- & 0,872 \\
\hline \multicolumn{5}{|c|}{ Resultado para a escala após a exclusão de um item: } \\
\hline $\begin{array}{l}\text { Auto-avaliação } \\
\text { conhecimento A }\end{array}$ & 2686,55 & 170918,20 & ,419 & ,869 \\
\hline $\begin{array}{l}\text { Auto-avaliação } \\
\text { conhecimento B }\end{array}$ & 2680,90 & 170784,69 & ,459 & ,868 \\
\hline $\begin{array}{l}\text { Auto-avaliação } \\
\text { conhecimento C }\end{array}$ & 2717,30 & 168669,05 & ,376 & ,869 \\
\hline $\begin{array}{l}\text { Auto-avaliação } \\
\text { conhecimento D }\end{array}$ & 2694,74 & 170363,24 & ,410 & 869 \\
\hline $\begin{array}{l}\text { Auto-avaliação } \\
\text { conhecimento E }\end{array}$ & 2683,83 & 171657,92 &, 353 & ,870 \\
\hline $\begin{array}{l}\text { Auto-avaliação } \\
\text { conhecimento F }\end{array}$ & 2708,88 & 169715,83 &, 349 &, 870 \\
\hline Sentimentos A & 2702,50 & 173521,76 & ,119 & ,875 \\
\hline Sentimentos B & 2699,58 & 173994,22 &, 132 &, 874 \\
\hline Sentimentos C & 2704,26 & 173825,60 &, 135 &, 874 \\
\hline Sentimentos D & 2694,38 & 172807,72 &, 159 & ,874 \\
\hline Sentimentos E & 2706,84 & 175987,30 & ,037 &, 876 \\
\hline Sentimentos F & 2713,83 & 175053,86 & ,101 & ,874 \\
\hline Sentimentos G & 2721,40 & 177167,89 &,- 003 &, 875 \\
\hline Sentimentos H & 2705,57 & 173049,15 &, 161 &, 873 \\
\hline Sentimentos I & 2693,28 & 177286,51 &,- 015 &, 876 \\
\hline Sentimentos J & 2702,66 & 174668,70 & ,097 &, 874 \\
\hline Sentimentos K & 2709,09 & 176696,87 &, 015 &, 875 \\
\hline $\begin{array}{l}\text { Atitudes Pró- } \\
\text { Ambiente A }\end{array}$ & 2681,10 & 167655,75 &, 535 & ,867 \\
\hline $\begin{array}{l}\text { Atitudes Pró- } \\
\text { Ambiente B }\end{array}$ & 2689,08 & 168388,72 &, 509 & ,867 \\
\hline $\begin{array}{l}\text { Atitudes Pró- } \\
\text { Ambiente C }\end{array}$ & 2671,10 & 167938,36 & 624 & ,866 \\
\hline $\begin{array}{l}\text { Atitudes Pró- } \\
\text { Ambiente D }\end{array}$ & 2700,22 & 166976,87 & ,458 & ,868 \\
\hline $\begin{array}{l}\text { Atitudes Pró- } \\
\text { Ambiente E }\end{array}$ & 2676,68 & 167473,99 & ,636 & ,866 \\
\hline $\begin{array}{l}\text { Atitudes Pró- } \\
\text { Ambiente F }\end{array}$ & 2676,76 & 167960,03 &, 547 & ,867 \\
\hline $\begin{array}{l}\text { Atitudes Pró- } \\
\text { Ambiente G }\end{array}$ & 2691,38 & 165860,95 &, 533 & ,866 \\
\hline $\begin{array}{l}\text { Atitudes Pró- } \\
\text { Ambiente H }\end{array}$ & 2681,04 & 168700,17 &, 549 & ,867 \\
\hline $\begin{array}{l}\text { Atitudes Pró- } \\
\text { Ambiente I }\end{array}$ & 2681,10 & 168101,01 &, 522 & 867 \\
\hline $\begin{array}{l}\text { Atitudes Pró- } \\
\text { Ambiente J }\end{array}$ & 2677,28 & 168929,92 & ,484 & ,868 \\
\hline $\begin{array}{l}\text { Atitudes Pró- } \\
\text { Ambiente K }\end{array}$ & 2686,77 & 167332,33 & ,437 & ,868 \\
\hline $\begin{array}{l}\text { Atitudes Pró- } \\
\text { Ambiente L }\end{array}$ & 2677,59 & 168643,59 & ,487 & 867 \\
\hline $\begin{array}{l}\text { Atitudes Pró- } \\
\text { Ambiente M }\end{array}$ & 2673,99 & 168454,68 &, 568 & 867 \\
\hline $\begin{array}{l}\text { Atitudes Pró- } \\
\text { Ambiente N }\end{array}$ & 2684,62 & 166639,02 &, 521 & ,867 \\
\hline $\begin{array}{l}\text { Atitudes Pró- } \\
\text { Ambiente O }\end{array}$ & 2681,81 & 167097,50 &, 550 & ,866 \\
\hline $\begin{array}{l}\text { Atitudes Pró- } \\
\text { Ambiente P }\end{array}$ & 2708,84 & 170453,37 & ,288 & ,871 \\
\hline
\end{tabular}

\begin{tabular}{|c|c|c|c|c|}
\hline & Média & Variância & $\begin{array}{c}\text { Correlação } \\
\text { entre o } \\
\text { item- escala }\end{array}$ & $\begin{array}{c}\text { Coeficiente } \\
\text { Alfa de } \\
\text { Cronbach }\end{array}$ \\
\hline Escala total & 2747,64 & 177641,740 & --- & 0,872 \\
\hline \multicolumn{5}{|c|}{ Resultado para a escala após a exclusão de um item: } \\
\hline Valores A & 2714,36 & 172677,10 & ,185 &, 873 \\
\hline Valores B & 2689,81 & 171645,10 &, 285 & ,871 \\
\hline Valores C & 2680,24 & 165831,55 &, 560 & ,866 \\
\hline Valores D & 2666,28 & 171543,79 &, 506 & ,868 \\
\hline Valores E & 2667,60 & 170971,98 &, 525 & 868 \\
\hline Valores F & 2676,83 & 171789,25 & ,245 & 871 \\
\hline Valores G & 2688,93 & 163862,96 &, 547 & 866 \\
\hline Valores $\mathrm{H}$ & 2681,48 & 167058,71 & ,416 & ,868 \\
\hline Valores I & 2666,83 & 170663,31 &, 597 & ,868 \\
\hline Valores J & 2664,76 & 171918,70 & ,624 & ,868 \\
\hline Valores K & 2670,67 & 168210,70 & ,613 & ,866 \\
\hline Valores L & 2675,37 & 168892,02 &, 531 &, 867 \\
\hline Valores M & 2697,72 & 173888,89 & 144 & ,873 \\
\hline $\begin{array}{l}\text { Afirmações } \\
\text { Paradigmas A }\end{array}$ & 2744,68 & 177558,70 & ,098 &, 872 \\
\hline $\begin{array}{l}\text { Afirmações } \\
\text { Paradigmas C }\end{array}$ & 2743,17 & 177624,77 & ,022 &, 872 \\
\hline $\begin{array}{l}\text { Afirmações } \\
\text { Paradigmas E }\end{array}$ & 2743,14 & 177602,53 & ,063 & ,872 \\
\hline $\begin{array}{l}\text { Afirmações } \\
\text { Paradigmas G }\end{array}$ & 2744,80 & 177624,67 & ,016 & ,872 \\
\hline $\begin{array}{l}\text { Afirmações } \\
\text { Paradigmas I }\end{array}$ & 2743,10 & 177634,72 &, 010 &, 872 \\
\hline $\begin{array}{l}\text { Afirmações } \\
\text { Paradigmas K }\end{array}$ & 2743,92 & 177656,62 &,- 018 &, 872 \\
\hline $\begin{array}{l}\text { Afirmações } \\
\text { Paradigmas L }\end{array}$ & 2743,20 & 177545,93 & , 148 & ,872 \\
\hline $\begin{array}{l}\text { Afirmações } \\
\text { Paradigmas O }\end{array}$ & 2743,92 & 177684,23 &,- 046 & ,872 \\
\hline $\begin{array}{l}\text { Afirmações } \\
\text { Paradigmas P }\end{array}$ & 2743,20 & 177694,15 &,- 073 &, 872 \\
\hline $\begin{array}{l}\text { Afirmações } \\
\text { Paradigmas B }\end{array}$ & 2743,99 & 177565,76 &, 074 &, 872 \\
\hline $\begin{array}{l}\text { Afirmações } \\
\text { Paradigmas D }\end{array}$ & 2743,95 & 177591,35 & ,064 &, 872 \\
\hline $\begin{array}{l}\text { Afirmações } \\
\text { Paradigmas F }\end{array}$ & 2744,73 & 177636,67 & ,004 &, 872 \\
\hline $\begin{array}{l}\text { Afirmações } \\
\text { Paradigmas H }\end{array}$ & 2743,54 & 177599,77 & ,047 & ,872 \\
\hline $\begin{array}{l}\text { Afirmações } \\
\text { Paradigmas J }\end{array}$ & 2743,67 & 177670,98 &,- 036 & ,872 \\
\hline $\begin{array}{l}\text { Afirmações } \\
\text { Paradigmas M }\end{array}$ & 2744,29 & 177702,65 &,- 065 & ,872 \\
\hline $\begin{array}{l}\text { Afirmações } \\
\text { Paradigmas N }\end{array}$ & 2743,04 & 177583,26 & ,098 & ,872 \\
\hline
\end{tabular}




\section{Análise de Gênero}

Como Padua (1997) detectou diferenças nas respostas entre meninos e meninas no pré-teste e pós-teste com grupos de estudantes em atividade de contato com a natureza, resolveu-se, complementarmente, verificar se haveria influência do gênero também no caso deste estudo.

As variáveis avaliadas foram as referentes a auto-avaliação do conhecimento, atitudes pró-ambiente, sentimentos e valores. Como o objetivo da análise é comparar dois grupos independentes (homens e mulheres), sendo que 0 grupo masculino é pequeno, optou-se por utilizar o teste não paramétrico de Mann-Whitney. Os resultados são expressos em termos do valor $p$. Os resultados estão apresentados no Anexo 4, onde os valores significativos com um nível de significância de $5 \%$ são destacados em negrito e sublinhado e os valores significativos com um nível de significância de 10\% também são destacados, apenas em negrito.

Com poucas exceções ( 07 análises com nível de significância menor que $5 \%$, e outras $8 \mathrm{com}$ nível de significância menor que 10\%), os testes demonstraram que, para este caso, não houve diferenças significativas entre os gêneros para a grande maioria das 184 variáveis testadas.

Padua (1997) atribuiu as diferenças entre gêneros ao

"fato dos meninos mostrarem maior conhecimento sobre o meio ambiente pode ter ocorrido devido ao contexto onde o programa foi realizado. No meio rural, os meninos ficam mais expostos ao ar livre, acompanhando as atividades paternas. As meninas, por sua vez, ajudam suas mães nos serviços da casa, o que as torna menos conhecedoras do ambiente natural" (PADUA, 1997, p.47).

Como este estudo foi realizado com estudantes universitários, esses fatores, acima apontados, não estariam influenciando os resultados, uma vez que se pode admitir que, tanto homens quanto mulheres tiveram oportunidades de formação cultural muito similares. Desta forma, a ausência de diferenças estatísticas observada pode ser facilmente compreendida. 


\section{Estudo 3b: Mudança de paradigmas: Desenvolvimento Sustentável X Sociedades Sustentáveis \\ Metodologia}

Como foi discutido anteriormente, um debate muito importante vem acontecendo entre os especialistas e refere-se às diferenças conceituais e metodológicas entre a Educação para o Desenvolvimento Sustentável e a Educação para as Sociedades Sustentáveis, dentro do contexto da Educação Ambiental.

Para Meira \& Sato (2005, p.9)

"as razões e discursos utilizados para que a Educação Ambiental dê um passo centrado na Educação para o Desenvolvimento Sustentável são demasiadamente inconsistentes. Ninguém é tão insano de rejeitar que os modelos de desenvolvimento devem sublinhar 0 ambiente e a sociedade. Uma parcela significativa acolhe 0 conceito de Desenvolvimento Sustentável, sem interrupção das atividades na Educação Ambiental (...). E tantas outras áreas do conhecimento, como a Filosofia Ambiental, Sociologia Ambiental, ou Psicologia Ambiental, entre outras, também enfrentam o mesmo dilema da EA".

Para Bourdieu, (1999, apud MEIRA \& SATO, 2005, p.3), no entanto,

"Nossa capacidade de vencer 0 itinerário dualista está na dependência do diálogo entre estas duas correntes. Seguramente não haverá um caminho certo e outro errado, e no marco do diálogo na diferença, talvez sejamos capazes de lançar mão das lutas identidárias acreditando em fraternidade, igualdade e liberdade. Porém se há liberdade, não pode haver igualdade. Se a EA configura-se realmente um campo sociológico, não podemos temer as tensões e os conflitos subjacentes nas esteiras de lutas políticas da própria EA".

Este estudo, complementar e realizado simultaneamente ao anterior, com o mesmo arranjo experimental, visa responder à seguinte questão: seriam as atividades de contato dirigido com a natureza suficientes para que os cidadãos percebam as diferentes concepções paradigmáticas entre a Educação Ambiental para o Desenvolvimento Sustentável e a Educação Ambiental para as Sociedades Sustentáveis? 
A Escala HEP-NEP foi ao longo do tempo se consagrando como uma das mais adequadas para medir atitudes (ver: PELLETIER, LEGAULT \& TUSON, 1996; DENG, WALKER \& SWINNERTON, 2006; WIIDEGREN, 1998; JOHNSON, BOWKER \& CORDELL, 2004; HERNÁNDEZ, et. al., 2000; NOONEY et. al, 2003). Essa foi a metodologia usada no presente experimento, e é inspirada nos trabalhos de Dunlap e seus colaboradores (DUNLAP, 2002; DUNLAP, et. al. 2000), adaptada para este estudo, na qual foram incluídas 16 afirmações, de modo e detectar-se a ideologia ambiental que o entrevistado identifica como adequada e possíveis transformações da mesma, de um conceito de Desenvolvimento Sustentável para outro de Sociedades Sustentáveis. Baseandonos na Teoria das Representações Sociais, partiu-se das seguintes premissas: (1) as velhas e novas idéias sobre as relações entre a humanidade e a natureza que circulam pelas sociedades tendem a co-existir e a interagir de formas complexas; (2) Esta interação assume diferentes formas, abrindo assim diferentes possibilidades para pensar e argumentar, ou seja, originando diferentes representações sociais; (3) por sua vez, as representações sociais são mais do que apenas conjuntos de crenças e; (4) o contato intenso e dirigido com ambientes naturais pode contribuir para a mudança dessas representações.

Nas questões da escala HEP-NEP testou-se os dois grandes paradigmas através do uso de escala de Likert $^{9}$ de cinco pontos. O primeiro,

${ }^{9}$ A escala de Likert se baseia na premissa de que a atitude geral se remete às crenças sobre o objeto da atitude, à força que mantém essas crenças e aos valores ligados ao objeto. $\mathrm{Na}$ escala de Likert, ou escala somatória, os respondentes não apenas respondem se concordam ou não com as afirmações, mas também informam qual seu grau de concordância ou discordância. É atribuído um número a cada resposta, que reflete a direção da atitude do respondente em relação a cada afirmação. A somatória das pontuações obtidas para cada afirmação é dada pela pontuação total da atitude de cada respondente. $O$ procedimento geral usado é o seguinte: são coletadas várias informações sobre determinado item. Estes itens são apresentados a juizes que indicam se aprovam muito, aprovam, estão indecisos, desaprovam, desaprovam muito. Para cada juiz é feito um score final computando suas respostas numa escala de 5 a 1, respectivamente. A avaliação das frases também pode ser feita segundo as seguintes divisões: concordo totalmente, concordo parcialmente, incerto, discordo parcialmente e discordo totalmente. Aos vários graus de concordância / discordância são atribuídos números para indicar a direção da atitude do respondente. Geralmente, os números utilizados variam de 1 a 5 , ou $-2,-1,0,+1$, +2. O conjunto de números utilizados não faz diferença em função das conclusões a que se quer chegar, o importante é que se atribua corretamente os números às respostas de afirmações positivas e negativas. A maior pontuação possível será a multiplicação do maior número utilizado (por exemplo, 5) pelo número de assertivas favoráveis, e a menor pontuação será a multiplicação do menor número 
denominado Paradigma das Sociedades Sustentáveis compreende as seguintes idéias: a Terra tem limitações de espaço e recursos; as pessoas também estão sujeitas a limites naturais; estamos abusando do ambiente e perturbando o delicado equilíbrio da natureza, o que pode nos conduzir à catástrofe; a ciência fornece-nos apenas respostas relativas, e apenas uma mudança no modelo civilizatório pode produzir uma sociedade sustentável. O segundo, denominado Paradigma do Desenvolvimento Sustentável, incorpora as seguintes noções: as capacidades humanas irão assegurar que seremos capazes de ultrapassar as limitações do presente, visto que fomos feitos para governar a natureza; o crescimento econômico é necessário para a resolução dos problemas sociais e a ciência é capaz de nos fornecer as explicações necessárias para a promoção do desenvolvimento sustentável.

Estes dois paradigmas são semelhantes àqueles que, por todo 0 mundo, têm sido encontrados com recurso à escala NEP. Remetem para a divisão clássica entre ecocentrismo (Paradigma das Sociedades Sustentáveis) e antropocentrismo (Paradigma do Desenvolvimento Sustentável). Eles remetem, também, para uma dimensão temporal, pois as novas idéias (da qual faz parte a Educação para as Sociedades Sustentáveis) estão reunidas no primeiro paradigma e as antigas (na qual a Educação para o Desenvolvimento Sustentável está incluída) no segundo.

Ao se aplica estes questionários a participantes (Grupo Experimental) e não participantes (Grupo Controle) e a participantes antes (Pré-teste) e alguns dias após (Pós-teste) as viagens ao PETAR, pode-se avaliar o quanto as atividades realizadas (contato com natureza) contribuíram para uma possível mudança do Paradigma do Desenvolvimento Sustentável para o Paradigma das Sociedades Sustentáveis (que implicaria numa mudança cognitiva refinada e complexa).

utilizado (por exemplo, 1) pelo número de assertivas desfavoráveis. A pontuação individual pode ser comparada com a pontuação máxima, indicando a atitude em relação ao problema apresentado. 


\section{As afirmativas (modificadas da escala HEP-NEP) que foram testadas}

\section{(incluídas no questionário de modo aleatório) são (TABELA 16):}

TABELA 16: Afirmativas relativas aos paradigmas testados.

\begin{tabular}{|c|c|}
\hline \multicolumn{2}{|r|}{ Afirmativas relativas aos Paradigmas Testados } \\
\hline \multicolumn{2}{|r|}{ Paradigma 1: Sociedade Sustentável } \\
\hline A & $\begin{array}{l}\text { A característica decisiva da economia deve ser a rejeição da busca de crescimento. O produto nacional } \\
\text { bruto deve ser reconhecido como um indicador em bancarrota. No lugar do PIB, as mudanças econômicas } \\
\text { e sociais, tanto quanto as tecnológicas, devem ser medidas por sua contribuição à sustentabilidade. }\end{array}$ \\
\hline B & $\begin{array}{l}\text { As sociedades sustentáveis devem ter populações estáveis, como as que têm hoje em dia } 13 \text { países } \\
\text { europeus e o Japão. A população mundial deve se estabilizar no máximo em oito bilhões de pessoas; }\end{array}$ \\
\hline $\mathrm{C}$ & $\begin{array}{l}\text { Nas indústrias, a reciclagem deve ser a única fonte de matéria prima. O desenho industrial deve se } \\
\text { concentrar na durabilidade e uso reiterado, em vez da vida curta e descartável dos produtos. O uso de } \\
\text { embalagens descartáveis deve ser eliminado; }\end{array}$ \\
\hline $\mathrm{D}$ & $\begin{array}{l}\text { Os bosques tropicais devem ser integralmente conservados. Não deve haver desmatamento para obtenção } \\
\text { de madeira e outros produtos. Pelo contrário, milhões de hectares de novas árvores devem ser plantados; }\end{array}$ \\
\hline E & $\begin{array}{l}\text { O uso exaustivo de pastagens deve ser eliminado, assim como deve haver modificação na cadeia alimentar } \\
\text { das sociedades humanas, para incluir menos carne e mais grãos e vegetais; }\end{array}$ \\
\hline $\mathrm{F}$ & $\begin{array}{l}\text { A terra é como uma nave espacial com somente poucos e limitados recursos que não podem ser facilmente } \\
\text { repostos. O equilíbrio da natureza é muito delicado, alterado facilmente, e de difícil recuperação; }\end{array}$ \\
\hline G & $\begin{array}{l}\text { Quando os seres humanos interferem com a natureza ela produz, freqüentemente, conseqüências } \\
\text { desastrosas.Os seres humanos devem viver na harmonia com natureza a fim sobreviver, em sociedades que } \\
\text { simplifiquem suas bases tecnológicas e consumam apenas o mínimo possível para garantir a qualidade de } \\
\text { vida; }\end{array}$ \\
\hline $\mathrm{H}$ & $\begin{array}{l}\text { A educação ambiental deve envolver uma perspectiva holística, enfocando a relação entre o ser humano, a } \\
\text { natureza e o universo de forma interdisciplinar. }\end{array}$ \\
\hline \multicolumn{2}{|r|}{ Paradigma 2: Desenvolvimento Sustentável } \\
\hline I & $\begin{array}{l}\text { É preciso garantir a satisfação das necessidades básicas da população (educação, alimentação, saúde, lazer, } \\
\text { etc), elaborando-se um sistema social que garanta emprego, segurança social e respeito a outras culturas } \\
\text { (erradicação da miséria, do preconceito e do massacre de populaçôes oprimidas, como por exemplo, os } \\
\text { índios); }\end{array}$ \\
\hline $\mathbf{J}$ & $\begin{array}{l}\text { É preciso que haja solidariedade para com as geraçães futuras (preservar o ambiente de modo que elas } \\
\text { tenham chance de viver), limitando o crescimento populacional, garantindo alimentação em longo prazo, } \\
\text { reservando a biodiversidade e os ecossistemas, diminuindo o consumo de energia e desenvolvendo } \\
\text { tecnologias que admitem o uso de fontes energéticas renováveis, aumentando a produção industrial nos } \\
\text { países não-industrializados à base de tecnologias ecologicamente adaptadas, controle da urbanização } \\
\text { selvagem e integração entre campo e cidades menores; e despoluindo rios e outros ambientes; }\end{array}$ \\
\hline $\mathrm{K}$ & $\begin{array}{l}\text { As organizações do desenvolvimento devem adotar a estratégia de desenvolvimento sustentável. Os seres } \\
\text { humanos têm o direito de modificar o ambiente natural, desde que o façam de modo a garantir a } \\
\text { recuperação natural dos recursos utilizados; }\end{array}$ \\
\hline $\mathrm{L}$ & $\begin{array}{l}\text { Para manter uma economia saudável nós teremos que desenvolver "uma economia sustentável" onde o } \\
\text { crescimento industrial seja controlado, mas que continue gerando riquezas e bens que possam auxiliar na } \\
\text { solução dos graves problemas ambientais; }\end{array}$ \\
\hline M & $\begin{array}{l}\text { Os seres humanos não necessitam adaptar-se ao ambiente natural porque podem manejá-lo de modo a } \\
\text { servir as suas necessidades, usando para isso, de modo racional, todo avanço científico e tecnológico } \\
\text { disponível; }\end{array}$ \\
\hline $\mathrm{N}$ & $\begin{array}{l}\text { Para o uso da madeira, é necessário que se faça o manejo sustentável das florestas, plantando-se novas } \\
\text { árvores a cada uma que é derrubada. }\end{array}$ \\
\hline $\mathrm{O}$ & $\begin{array}{l}\text { No futuro, será possível otimizar o sistema de transporte. As pessoas devem se movimentar mediante } \\
\text { sistemas altamente desenvolvidos de ônibus e transportes sobre trilhos; }\end{array}$ \\
\hline $\mathrm{P}$ & $\begin{array}{l}\text { As empresas de reciclagem devem ocupar o lugar das atuais companhias de limpeza urbana e disposição } \\
\text { final do lixo, todos os materiais descartáveis devem ser coletados de modo a alimentar a indústria com } \\
\text { matéria prima novamente utilizável; }\end{array}$ \\
\hline
\end{tabular}


Resultados

TP X TT - o efeito da turma sobre o escore dos indivíduos

Para o Teste de Hipóteses, como no estudo anterior, primeiramente considerou-se o efeito da turma sobre a resposta média dos indivíduos. Como as duas turmas formam grupos independentes, elas foram comparadas entre si em cada uma das medidas: pré e pós, nos grupos controle e experimental. O teste não paramétrico utilizado para comparação de dois grupos independentes foi, novamente, o Teste de Mann-Whitney. Os resultados são expressos pelo valor $\mathrm{p}$ do teste nas tabelas a seguir, agrupadas por tipo de variável. Valores menores que o nível de significância de $5 \%(0,05)$ indicam que há diferença significativa entre as respostas de TP e TT, e estão assinaladas na células em negrito (TABELA 17).

TABELA 17: Teste de Mann-Whitney para comparação das turmas Pedagogia (TP) e Turismo (TT), em cada uma das medidas.

\begin{tabular}{|c|c|c|c|c|}
\hline \multirow{3}{*}{ Teste de Paradigmas } & \multicolumn{4}{|c|}{ TURISMO (TT) X PEDAGOGIA (TP) } \\
\hline & \multicolumn{2}{|c|}{ CONTROLE } & \multicolumn{2}{|c|}{ EXPERIMENTAL } \\
\hline & PRÉ & POS & PRÉ & POS \\
\hline Afirmação A & 0,845 & 0,844 & 0,845 & 0,836 \\
\hline Afirmação C & 0,992 & 0,895 & 0,813 & 0,954 \\
\hline Afirmação E & 0,896 & 1,000 & 0,758 & 0,994 \\
\hline Afirmação G & 0,958 & 0,900 & 0,901 & 0,706 \\
\hline Afirmação I & 0,529 & 0,873 & 0,534 & 0,668 \\
\hline Afirmação K & 0,904 & 0,639 & 0,664 & 0,973 \\
\hline Afirmação L & 0,950 & 0,895 & 0,441 & 0,815 \\
\hline Afirmação O & 0,952 & 0,961 & 0,686 & 0,993 \\
\hline Afirmação P & 0,954 & 1,000 & 0,939 & 0,953 \\
\hline Afirmação B & 0,902 & 0,859 & 0,948 & 1,000 \\
\hline Afirmação D & 0,878 & 0,973 & 0,786 & 0,803 \\
\hline Afirmação F & 0,936 & 0,848 & 1,000 & 0,667 \\
\hline Afirmação H & 0,922 & 0,754 & 0,888 & 0,903 \\
\hline Afirmação J & 0,784 & 0,723 & 0,845 & 0,976 \\
\hline Afirmação M & 0,846 & 0,772 & 0,534 & 0,912 \\
\hline Afirmação N & 1,000 & 0,716 & 0,799 & 1,000 \\
\hline
\end{tabular}

Controle x Experimental nos períodos pré e pós-experimento

Em seguida, considera-se a comparação dos grupos controle e experimental entre si, tanto antes quanto após a intervenção. Por se tratar da 
comparação de dois grupos independentes, novamente será utilizado o teste não paramétrico de Mann-Whitney. Os valores significativos estão indicados na células em negrito (TABELA 18).

TABELA 18: Teste de Mann-Whitney para comparação dos grupos Controle e Experimental, em cada uma das turmas e das medidas.

\begin{tabular}{|c|c|c|c|c|}
\hline \multirow{3}{*}{ Teste de Paradigmas } & \multicolumn{4}{|c|}{ CONTROLE X EXPERIMENTAL } \\
\hline & \multicolumn{2}{|c|}{ TURISMO (TT) } & \multicolumn{2}{|c|}{ PEDAGOGIA (TP) } \\
\hline & PRÉ & POS & PRÉ & POS \\
\hline Afirmação A & 0,921 & 0,560 & 0,947 & 0,919 \\
\hline Afirmação C & 0,773 & 0,612 & 0,989 & 0,844 \\
\hline Afirmação E & 0,198 & 0,343 & 0,306 & 0,536 \\
\hline Afirmação G & 0,998 & 0,239 & 0,870 & 0,319 \\
\hline Afirmação I & 0,787 & 0,582 & 0,726 & 0,784 \\
\hline Afirmação K & 0,090 & 0,483 & 0,277 & 0,264 \\
\hline Afirmação L & 0,423 & 0,319 & 0,952 & 0,644 \\
\hline Afirmação O & 0,801 & 0,342 & 0,980 & 0,426 \\
\hline Afirmação P & 0,040 & 0,006 & 0,033 & 0,009 \\
\hline Afirmação B & 0,995 & 0,239 & 0,846 & 0,358 \\
\hline Afirmação D & 0,555 & 0,861 & 0,684 & 0,926 \\
\hline Afirmação F & 0,211 & 0,529 & 0,253 & 0,956 \\
\hline Afirmação H & 0,529 & 0,809 & 0,766 & 0,837 \\
\hline Afirmação J & 0,332 & 0,614 & 0,172 & 0,351 \\
\hline Afirmação M & 0,633 & 0,315 & 0,406 & 0,106 \\
\hline Afirmação N & 0,227 & 0,583 & 0,391 & 0,795 \\
\hline
\end{tabular}

Pré x Pós no caso da condição controle e da condição experimental Em cada turma de alunos (TT e TP) serão comparados agora os resultados pré e pós-intervenção no grupo experimental e no grupo controle (TABELA 19). Esperava-se que não haja diferença significativa entre os resultados do grupo controle, e que haja diferença significativa entre os resultados do grupo experimental. 
TABELA 19: Teste de Mann-Whitney para comparação dos resultados Pré e Pós intervenção, em cada um dos grupos e das medidas.

\begin{tabular}{|c|c|c|c|c|}
\hline \multirow{2}{*}{ Teste de Paradigmas } & \multicolumn{4}{|c|}{ PRE X POS } \\
\cline { 2 - 5 } & \multicolumn{2}{|c|}{ TURISMO (TT) } & \multicolumn{2}{c|}{ PEDAGOGIA (TP) } \\
\cline { 2 - 5 } & CONTROLE & EXPERIMENTAL & CONTROLE & EXPERIMENTAL \\
\hline Afirmações Paradigmas A & 0,619 & 0,930 & 0,646 & 0,775 \\
\hline Afirmações Paradigmas C & 0,289 & 0,230 & 0,268 & 0,204 \\
\hline Afirmações Paradigmas E & 0,656 & 0,999 & 0,457 & 0,811 \\
\hline Afirmações Paradigmas G & 0,662 & 0,511 & 0,583 & 0,874 \\
\hline Afirmações Paradigmas I & 0,417 & 0,083 & 0,220 & 0,065 \\
\hline Afirmações Paradigmas K & 0,446 & 0,765 & 0,870 & 0,886 \\
\hline Afirmações Paradigmas L & 0,686 & 0,611 & 0,508 & 0,250 \\
\hline Afirmações Paradigmas O & 0,981 & 0,644 & 0,888 & 0,382 \\
\hline Afirmações Paradigmas P & 0,127 & 0,083 & 0,112 & 0,146 \\
\hline Afirmações Paradigmas B & 0,159 & 0,844 & 0,213 & 0,910 \\
\hline Afirmações Paradigmas D & 0,749 & 0,921 & 0,616 & 0,987 \\
\hline Afirmações Paradigmas F & 0,278 & 0,607 & 0,242 & 0,893 \\
\hline Afirmações Paradigmas H & 0,874 & 0,846 & 0,746 & 0,891 \\
\hline Afirmações Paradigmas J & 0,841 & 0,078 & 0,666 & 0,059 \\
\hline Afirmações Paradigmas M & 0,549 & 0,567 & 0,456 & 0,176 \\
\hline Afirmações Paradigmas N & 0,116 & 0,370 & 0,055 & 0,235 \\
\hline
\end{tabular}

Os boxplots e os gráficos construídos com base na mediana, primeiro e terceiro quartis, e valores mínimo e máximo deste estudo também estão apresentados nos Anexos 2 e 3.

A ausência de diferenças significativas também pode ser constatada na comparação dos grupos dependentes (ou pareados) através do Teste não paramétrico de Wilcoxon. Considerou-se o nível de significância de 5\%. Os poucos resultados significativos na comparação de pré e pós intervenção foram destacados em negrito (TABELA 20). 
TABELA 20: Diferenças estatísticas referentes às afirmações nos Pré e Pós-Testes.

TT - Controle
\begin{tabular}{|l|r|r|}
\hline $\begin{array}{l}\text { Afirmações referentes aos } \\
\text { Paradigmas } \\
\text { Pós x Pré }\end{array}$ & \multicolumn{1}{c|}{ Z } & \multicolumn{1}{c|}{ Valor p } \\
\hline Afirmações Paradigmas A &,- 556 &, 621 \\
\hline Afirmações Paradigmas C &,- 144 & 1,000 \\
\hline Afirmações Paradigmas E &, 000 & 1,000 \\
\hline Afirmações Paradigmas G &,- 036 &, 992 \\
\hline Afirmações Paradigmas I & $-1,508$ &, 227 \\
\hline Afirmações Paradigmas K &,- 377 &, 723 \\
\hline Afirmações Paradigmas L &,- 439 &, 797 \\
\hline Afirmações Paradigmas O & $-1,001$ &, 360 \\
\hline Afirmações Paradigmas P & $-1,539$ &, 172 \\
\hline Afirmações Paradigmas B & $-1,773$ &, 087 \\
\hline Afirmações Paradigmas D &,- 479 &, 683 \\
\hline Afirmações Paradigmas F & $-1,977$ &, 065 \\
\hline Afirmações Paradigmas H &,- 465 &, 745 \\
\hline Afirmações Paradigmas J &,- 431 &, 698 \\
\hline Afirmações Paradigmas M &,- 592 &, 606 \\
\hline Afirmações Paradigmas N & $-2,309$ &, 035 \\
\hline
\end{tabular}

TT - Experimental

\begin{tabular}{|l|r|r|}
\hline $\begin{array}{l}\text { Afirmações referentes aos } \\
\text { Paradigmas } \\
\text { Pós X Pré }\end{array}$ & \multicolumn{1}{c|}{ Z } & Valor $\mathrm{p}$ \\
\hline Afirmações Paradigmas A &,- 160 &, 887 \\
\hline Afirmações Paradigmas C &,- 988 &, 383 \\
\hline Afirmações Paradigmas E &,- 097 &, 973 \\
\hline Afirmações Paradigmas G &,- 880 &, 420 \\
\hline Afirmações Paradigmas I & $-1,721$ &, 117 \\
\hline Afirmações Paradigmas K &,- 420 &, 718 \\
\hline Afirmações Paradigmas L &,- 263 &, 734 \\
\hline Afirmações Paradigmas O &,- 292 &, 826 \\
\hline Afirmações Paradigmas P & $-1,615$ &, 107 \\
\hline Afirmações Paradigmas B &,- 708 &, 563 \\
\hline Afirmações Paradigmas D &,- 443 &, 745 \\
\hline Afirmações Paradigmas F &,- 705 &, 535 \\
\hline Afirmações Paradigmas H &,- 206 &, 867 \\
\hline Afirmações Paradigmas J & $-1,652$ &, 110 \\
\hline Afirmações Paradigmas M &,- 491 &, 646 \\
\hline Afirmações Paradigmas N &,- 952 &, 438 \\
\hline
\end{tabular}

TP - Controle

\begin{tabular}{|l|r|r|}
\hline $\begin{array}{l}\text { Afirmações referentes } \\
\text { aos Paradigmas }\end{array}$ & \multicolumn{1}{c|}{ Z } & Valor $\mathrm{p}$ \\
\hline Pós X Pré &,- 709 &, 507 \\
\hline Afirmações Paradigmas A &,- 586 &, 592 \\
\hline Afirmações Paradigmas C &,- 258 & 1,000 \\
\hline Afirmações Paradigmas E &,- 016 &, 989 \\
\hline Afirmações Paradigmas G & $-1,430$ &, 172 \\
\hline Afirmações Paradigmas I &,- 191 &, 879 \\
\hline Afirmações Paradigmas K &,- 374 &, 749 \\
\hline Afirmações Paradigmas L &,- 382 &, 745 \\
\hline Afirmações Paradigmas O & $-2,111$ &, 063 \\
\hline Afirmações Paradigmas P & $-1,542$ &, 133 \\
\hline Afirmações Paradigmas B & $-1,408$ &, 223 \\
\hline Afirmações Paradigmas D &,- 923 &, 385 \\
\hline Afirmações Paradigmas F &,- 121 &, 921 \\
\hline Afirmações Paradigmas H &,- 219 &, 872 \\
\hline Afirmações Paradigmas J &,- 777 &, 460 \\
\hline Afirmações Paradigmas M & $-1,795$ &, 108 \\
\hline Afirmações Paradigmas N
\end{tabular}

\section{TP - Experimental}

\begin{tabular}{|l|r|r|}
\hline $\begin{array}{l}\text { Afirmações referentes aos } \\
\text { Paradigmas }\end{array}$ & \multicolumn{1}{c|}{ Z } & \multicolumn{1}{c|}{ Valor $\mathrm{p}$} \\
\hline Afirmações Paradigmas A &,- 381 &, 740 \\
\hline Afirmações Paradigmas C & $-1,136$ &, 295 \\
\hline Afirmações Paradigmas E &,- 036 & 1,000 \\
\hline Afirmações Paradigmas G &,- 021 & 1,000 \\
\hline Afirmações Paradigmas I & $-1,466$ &, 155 \\
\hline Afirmações Paradigmas K &,- 122 &, 969 \\
\hline Afirmações Paradigmas L &,- 566 &, 682 \\
\hline Afirmações Paradigmas O &,- 893 &, 380 \\
\hline Afirmações Paradigmas P & $-1,999$ &, 042 \\
\hline Afirmações Paradigmas B &,- 320 &, 759 \\
\hline Afirmações Paradigmas D &,- 042 & 1,000 \\
\hline Afirmações Paradigmas F &,- 112 &, 921 \\
\hline Afirmações Paradigmas H &,- 238 &, 854 \\
\hline Afirmações Paradigmas J & $-1,365$ &, 179 \\
\hline Afirmações Paradigmas M & $-1,117$ &, 311 \\
\hline Afirmações Paradigmas N &,- 775 &, 613 \\
\hline
\end{tabular}




\section{5 \\ Discussão e Conclusões}

O Fluxograma abaixo mostra, sinteticamente, o que foi feito em cada etapa, apenas para facilitar a compreensão sobre os vários procedimentos adotados (FIGURA 10).

Observação Participante de atividades dirigidas de contato com natureza
Formulação da hipótese Central: atividades dirigidas de contato com a natureza podem contribuir com a transformação de valores e atitudes na direção próambiente.

Estudos Iniciais: análise junto a freqüentadores de áreas naturais quanto às motivações para sua visita e as opiniões de Educadores Ambientais e outros profissionais da área sobre as razões para sua adesão ao tema bem como opinião sobre estratégias de trabalho mais eficientes (todos realizados através de questionários).

Primeiros resultados sugerem haver um papel significativo do contato com a natureza na gênese de comportamentos pró-ambientais.

Realização de estudos experimentais, através de arranjo especialmente desenvolvido para comparação de grupos em situações diferenciadas ("contato dirigido" e "não contato" com a natureza), para medir possíveis mudanças de sentimentos, aumento de conhecimentos e formação de valores e atitudes, além de percepções diferentes de paradigmas ambientais.
Resultados apontam para a confirmação da importância do contato dirigido com a Natureza, e para o seu potencial como instrumento de Educação Ambiental

FIGURA 10: Fluxograma dos estudos realizados. 
Este trabalho faz uma tentativa de transformar mais de 16 anos de observações empíricas em pesquisa científica. Tenta medir aquilo que, intuitivamente, essa longa experiência faz acreditar como estratégia eficaz de Educação Ambiental. O desafio é enorme, como já discutido, pois atitudes não são diretamente mensuráveis.

Somos cientes de que imprecisões e dúvidas ainda podem permanecer presentes, mesmo após os estudos realizados e a despeito das convicções advindas da experiência empírica. No entanto, pelos resultados aqui relatados, cada um com objetivo de refinar cada vez mais a mensuração do fenômeno defendido pela tese central, a conclusão que se vislumbra é que o contato com a natureza parecer ser um forte motivador para a mudança de atitudes em relação ao meio ambiente. A relevância destas atividades na transformação dos conhecimentos, valores e atitudes em direção a um comportamento pró-ambiente foi detectada estatisticamente pelo estudo 3a, e é perceptível nos demais estudos deste trabalho.

Resultados similares foram obtidos por Quaranta-Gonçalves, Guimarães \& Soares (2006) que, após avaliarem excursões realizados com alunos mostram que os mesmo emitem opiniões contraditórias sobre a natureza, alguns a descrevendo como local aprazível, outros como lugar de medo e receios, manifestações contraditórias entre sentimentos ora de Topofilia, ora de Topofobia muitas vezes conjugados, mas com claro predomínio dos primeiros sobre os segundos.

Resumidamente, listamos as respostas obtidas às questões formuladas nas páginas 59 e 60 :

1a) O contato com a natureza é a principal motivação para as viagens de pessoas às áreas naturais, sendo os motivos ligados a emoção, o impulso ao prazer (mesmo que provocado pela busca de representações sociais do paraíso edênico) os mais significativos;

1b) O contato com a natureza, juntamente com a influência de outras pessoas que Ihes servem de exemplo, é apontado por educadores ambientais e outros profissionais e atores sociais que trabalham com a temática ambiental 
como os fatores determinantes na sua opção profissional. No entanto, contrariamente a esta convicção, apostam em estratégias de Educação Ambiental mais focadas em aspectos racionais do que emocionais;

2a) O contato intensificado com ambientes naturais é uma conduta eficiente para transformar atividades de contato com a natureza (e as ecoturísticas aqui incluídas) em experiências significativas de vida. As características pessoais mais bem aprofundadas em atividades dirigidas são: o nível de conhecimento, os valores e as atitudes. Para a maioria dos sentimentos, apesar de não estar descartada a hipótese de serem trabalhados nessas atividades (aliás, muito pelo contrário), não apresentaram alteração significativa alguns dias após a realização das mesmas.

2b) As viagens dirigidas à natureza não são suficientes para que os indivíduos percebam as diferenças conceituais e metodológicas entre os paradigmas de Desenvolvimento Sustentável e de Sociedades Sustentáveis;

Essas respostas podem ser confirmadas pela análise dos resultados dos estudos experimentais.

\section{Experimento $3 a$}

Apesar de TP e TT serem Grupos oriundos de cidades diferentes e terem formação diferenciada (Pedagogia e Turismo, respectivamente), os resultados apontam para similaridades de resultados nas variáveis testadas. Ou seja, o curso de origem produz poucas diferenças nas respostas dos alunos, que podem inclusive ser casuais (vide TABELAS 5a, 5b, 5c e 5d).

Os resultados da comparação dos grupos controle e experimental entre si, tanto antes quanto após a intervenção demonstram que nos Pré-Testes há diferenças significativas entre os grupos Controle e Experimental somente em relação a alguns itens (atitudes "Participar do movimento ambientalista " - TT e TP, "Ler a respeito ou assistir documentários sobre meio ambiente" - TP, "Cuidar de plantas e animais" - TT e TP, "Filiar-se à uma ONG ambientalista" - TT, "Doar recursos ou trabalhar voluntariamente para a Conservação Ambiental" - TT; Valores "O que você acha da relação dos animais da mata com o homem? " - TT, 
"O que você sente quando vê áreas de mata queimando?" - TT e TP, " A preservação da Mata Atlântica" - TP, e "A natureza ensina ao ser humano como ele deve viver" - TP), o que indica que os grupos controle e experimental tem conhecimentos, atitudes e valores equivalentes antes da viagem. No entanto, há grandes diferenças nos Pós-testes, o que sugere mudanças oriundas da viagem. Essas diferenças são muito evidentes nos testes de Auto-Avaliação de conhecimentos, de valores e de atitudes (vide TABELA 6a, 6b e 6c)

Ao contrário dos resultados obtidos por Alvarenga \& Nogueira-Filho (2005) as diferenças entre controle e experimental não são significativas para a maioria dos sentimentos (vide TABELA 7). Há também uma disparidade quando se compara os pré-testes com os pós-testes, o que pode ser explicado pelo fato dos questionários terem sido aplicados, no pós-teste, alguns dias após a experiência. Os resultados obtidos por Alvarenga \& Nogueira-Filho (2005) num experimento similar, mediram os sentimentos ainda durante a realização da atividade (no mesmo dia, ao final dos trabalhos), detectando-se, assim, significativa mudanças de estados emocionais após realização de atividades na natureza. Talvez a diferença com os dados aqui obtidos esteja justamente nessa variação procedimental. Sentimentos e estados emocionais são fenômenos fugazes, sendo inúmeros os fatores que podem alterálos subitamente. No caso de Alvarenga \& Nogueira-Filho (2005) os alunos, ao responderem no "calor da hora", revelaram mais claramente os sentimentos oriundos da experiência (também observados no nosso caso, mas não avaliados), enquanto aqui, passado alguns dias, outros fatores externos podem ter influenciado sentimentos de modo que a eventual transformação não esteja mais perceptível.

No entanto, conforme demonstra a TABELA 9, os alunos da TT que realizaram a viagem e participaram das atividades dirigidas mostraram diferenças maiores para alguns sentimentos, significando que estavam mais alertas $(p=0,000)$, mais satisfeitos $(p=0,003)$, mais interessados $(p=0,009)$ e mais confiantes. Os alunos da TP apresentaram mudanças significativas para três desses sentimentos (mais alertas: $p=0,000$; mais satisfeitos: $p=0,011$; e mais interessados: $p=0,014)$ além de também se sentirem mais seguros $(p=0,007)$. Para os demais sentimentos não houve mudanças significativas. Como esses 
resultados significativos, apesar de não terem ocorrido a todos os sentimentos, aparecem apenas nos grupos experimentais, há a possibilidade de terem surgido, pelo menos em parte, por influência da viagem. Talvez alguns sentimentos tenham permanência mais duradoura que outros, neste caso, sendo possível detectá-los mesmo alguns dias após a realização do contato com a natureza. Isso parece especialmente verdadeiro para os sentimentos "alerta", "satisfeito" e "interessado", que apresentou diferenças significativas entre pré e pós tanto em TT quanto em TP experimentais.

Quanto aos conhecimentos, as respostas encontradas possibilitaram concluir que o trabalho orientado realizado na viagem ao PETAR é eficiente para retenção dos mesmos por parte dos alunos, tanto em TT quanto em TP. Vale lembrar que a análise estatística dos Grupos Experimental e Controle mostrou que no Pré-Teste não havia diferenças significativas para a grande maioria das variáveis entre os grupos, indicando que tinham um mesmo nível no início dos testes. No Pós-Teste, os alunos que viajaram são os que apresentaram maiores diferenças entre as médias obtidas em relação ao Pré-Teste (vide TABELA 8).

Pode-se concluir que, com as exceções dos temas "Meio Ambiente" e "Educação Ambiental" da TT, houve declaração de progresso nos conhecimentos dos alunos após a realização das atividades dirigidas na viagem. Essas exceções podem estar revelando o grau de imprevisibilidade dos resultados quando se trabalha com aspectos ligados a Educação, que não podem ser reduzidos a um processo do tipo "tudo ou nada".

A viagem contribuiu para a melhoria dos conhecimentos de uma maneira global, mas os temas que mais apresentaram mudanças estão diretamente relacionadas com aqueles conhecimentos trabalhados durante a vivência nas atividades realizadas na viagem. O tema mais diretamente trabalhado na viagem (cavernas de calcário) é justamente o que apresenta a maior diferença, principalmente quando comparado com temas mais "genéricos" (meio ambiente, por exemplo).

Quanto aos "valores" avaliados, há mudanças significativas para 4 (quatro) deles ( $\mathrm{O}$ que você sente quando vê áreas de mata queimando?; $\mathrm{O}$ que 
você sente ao visitar áreas naturais?; Você concorda com a afirmação "a preservação da Mata Atlântica é urgente"?; e O que você sente quando está em contato direto com a Natureza?) entre Pré e Pós-Teste ( $p=0,001 ; p=0,008$; $p=0,011$ e $p=0,004$, respectivamente) na TT-Controle (vide TABELA 10), o que interfere na aceitação dos resultados obtidos para os mesmos na TT-Experimental e aponta para a existência de outros fatores que podem ter atuado nessa mudança de valores, exteriores à viagem.

Vale ressaltar, ainda, que para dois valores avaliados na TP-Experimental (O que você acha da relação dos animais da mata com o homem?; e Qual sua emoção ao entrar em uma mata?) não houve mudanças significativas entre o Pré e o Pós-Teste ( $p=0,085$ e $p=0,139$, respectivamente). No entanto, devido aos demais resultados obtidos para esses mesmos Grupos referente aos outros valores avaliados, é possível se afirmar que a viagem, de maneira global, contribui de maneira muito significativa para essa mudança.

Como não há exceções com relação às "atitudes" (vide TABELA 11), os resultados demonstram que talvez aqui esteja o maior potencial das atividades dirigidas na natureza, o que reforça a opinião de Bruhns (2000) de que as experiências vivenciadas através de práticas de contato com natureza podem ser uma oportunidade do surgimento de novas atitudes e sentimentos, que venham a fundir sentidos corporais e respeito pelo meio ambiente. Esses resultados são também concordantes com aqueles obtidos por Quaranta-Gonçalves, Guimarães \& Soares (2006), que demonstraram como estudantes adquiriram uma nova visão sobre o que é um meio ambiente natural e porque é necessário preservá-lo a partir do contato direto com o Parque Estadual do Jaraguá e o Parque Estadual da Cantareira.

Validade interna e externa

O delineamento de pesquisa caracterizado por pré-teste e pós-teste controla quase todas as ameaças à validade interna de um estudo. A separação dos alunos em grupo de controle ou experimental também evita possibilidades de erro experimental. Esse desenho oferece a mesma chance aos dois grupos e os expõe aos mesmos riscos (HUCK et. al. 1974, apud PADUA, 1997). Neste caso, os alunos participantes do Grupo Experimental optaram por participar da viagem, 
pois a mesma fazia parte de atividades regulares de seus respectivos cursos de graduação. Como a participação envolvia custos financeiros, muitos dos alunos que estavam muito motivados a participar, não puderam fazê-lo e compuseram o Grupo Controle. Outros tantos, mesmo pouco motivados com o destino em si da viagem, participaram da mesma, pois além de terem condições financeiras para isso, queriam acompanhar os demais colegas nas atividades. Desta forma, não é temerário afirmar que a distribuição dos alunos pelos Grupos não se deu de forma a privilegiar um conjunto de alunos "naturalmente motivado" em realizar visitas à natureza no Grupo Experimental nem um conjunto averso a esse tipo de atividade no Controle. A simples distribuição aleatória (por meio de sorteio ou similar) não foi possível neste caso justamente pelo envolvimento financeiro. Outro cuidado tomado, foi escolher, dentre as 107 viagens realizadas, duas nas quais os alunos eram ligados a cursos de ciências humanas (turismo e pedagogia), de modo a minimizar as motivações naturais que estudantes de outras áreas (biologia, geologia, agronomia, engenharia florestal, gestão ambiental, etc.,) tem por saídas a campo em parques naturais.

No que se refere à validade externa, ou seja, a possibilidade de generalização a outras realidades dos resultados obtidos, pode-se afirmar que, pelo menos nas 107 viagens realizadas, o perfil do público trabalhado não diferenciou muito daquele observado em atividades de Educação Ambiental e Ecoturismo, de modo ser razoável acreditar que, no tocante a públicos de mesmo nível social, econômico e educacional, os resultados possam ser similares. Podese então fazer uma inferência dos dados obtidos nesse estudo para outras populações com realidades semelhantes. Padua (1997) aponta que o pré-teste pode influenciar os resultados, uma vez que chama a atenção para determinados tópicos que serão novamente perguntados posteriormente. Para diminuir esta influência, os participantes não foram informados, no momento do pré-teste sobre objetivos da pesquisa, nem foi apontada a sua relação direta com as viagens que seriam realizadas, o que só ocorreu após o pós-teste. 


\section{Experimento $3 \mathrm{~b}$}

Os resultados obtidos indicam que não há diferença significativa entre os grupos Controle (pré e pós), e os grupos Experimental (pré e pós) (TABELA 17). Esse resultado reforça a conclusão do estudo anterior de que, apesar de serem oriundas de cidades diferentes e terem formação diferenciada (Pedagogia e Turismo), as Turmas apresentam similaridades nos resultados da variável testada.

Os resultados da TABELA 18 demonstram tanto quanto nos Pré-Testes, os Pós-Testes não apresentam diferenças significativas entre os grupos Controle e Experimento (com exceções da afirmação da afirmação "P"), ou seja, os grupos "partiram" e "chegaram" de pontos semelhantes; a viagem não contribuiu para uma mudança da percepção entre os dois paradigmas.

A comparação dos resultados pré e pós-intervenção desmente a hipótese de que não haja diferença significativa entre os resultados do grupo controle, e que haja diferença significativa entre os resultados do grupo experimental. Ou seja, ficou demonstrado que a viagem não provocou mudanças significativas (TABELA 19); há uma ausência de diferenças tanto no Pré-Teste como no Pós-teste.

Desta forma, o debate conceitual entre os defensores do Desenvolvimento Sustentável e os das Sociedades Sustentáveis, apesar de importante para os especialistas e que realmente precisa avançar, uma vez que isso implica em dcisões que podem fazer a diferença entre a possibilidade ou não de se alcançar a sustentabilidade, ainda não é significativo ou perceptível para o "cidadão comum".

Apesar disso, vale destacar, como ilustram os Anexos 2 e 3, o alto grau de concordância com todas as afirmativas de maneira geral (médias quase sempre acima de 3 na escala de Likert, com maioria para 4 ou 5), que representam de certa forma, ora num, ora noutro paradigma, atitudes próambiente desejáveis e muito divulgadas pela sociedade. Como as questões relativas a cada paradigma não foram abordadas diretamente durante a viagem, seria realmente surpreendente que elas se manifestassem em tão curto período de tempo, mas a aquisição de uma consciência do que seria ecologicamente 
correto parece já estar presente em todos os indivíduos participantes do arranjo experimental.

A escala HEP-NEP baseia-se no fato que a humanidade está mudando radicalmente a sua forma de encarar as suas relações com a natureza, encaminhando-se consensualmente para formas mais respeitosas e ecológicas de se relacionar com esta (DUNLAP, 2000). Para esta perspectiva, as velhas idéias antropocêntricas relativas à natureza estariam sendo substituídas por novas idéias ecológicas, em conseqüência da humanidade estar tomando ciência da seriedade e da importância dos problemas ambientais.

A adaptação na escala aqui utilizada fez uma tentativa mais refinada de medir essa transformação. O fato dos resultados não terem se mostrado significativos não invalida o instrumento; apenas revela que, no caso deste estudo, as atividades de contato com a natureza, da maneira como foram conduzidas, não produzem uma mudança mensurável de crença no paradigma do Desenvolvimento Sustentável para uma crença no paradigma das Sociedades Sustentáveis. Para caminhar neste sentido, alguns ajustes precisariam ser realizados, caso esse seja um dos objetivos futuros dessas viagens.

Vale ressaltar, no entanto, que, apesar do Paradigma das Sociedades Sustentáveis não ser trabalhado conceitualmente, as atividades desenvolvidas na viagem (e aqui defendidas como adequadas para a Educação Ambiental) estão atreladas epistemológica e metodologicamente aos nove princípios interligados que, segundo o PNUMA $^{10}$ (ORGANIZAÇÃO DAS NAÇÕES UNIDAS, 1991), descrevem esse paradigma:

- Respeito e cuidado com a comunidade dos seres vivos;

- Melhoraria da qualidade de vida humana;

- Conservação da vitalidade e da diversidade do Planeta Terra;

- Minimização do esgotamento dos recursos não-renováveis;

- Permanência no limite da capacidade de suporte do Planeta Terra;

- Modificação de atitudes e práticas pessoais;

- Permissão para que as comunidades cuidem do seu próprio ambiente;

- Geração de uma estrutura nacional para integrar desenvolvimento e conservação;

- Construção de uma aliança global.

\footnotetext{
${ }^{10}$ Programa das Nações Unidas para o Meio Ambiente.
} 


\section{Conclusões}

A questão ambiental é tema recorrente do debate social atual. É uma construção social relevante de uma modernidade que se tornou reflexiva sobre seus próprios rumos, que busca uma nova racionalidade, que almeja a sustentabilidade, e para tanto cria novas representações sobre o ambiente. Nesse contexto, a mudança de comportamentos volta a ter uma dimensão relevante e a busca de um novo paradigma alternativo para o futuro da civilização se torna anseio de todos. Ou, como aponta Carvalho (2001), surge a invenção ecológica e seu correlato, o sujeito ecológico.

Sendo o mundo que nos envolve mediado por representações sociais que se constituem em modalidade de conhecimento e revelam coisas sobre o real e os objetos que o constituem, essas representações permitem esclarecer as concepções dos sujeitos sobre o meio. "Desta forma possibilita avaliar a nível simbólico e cultural a dimensão espacial, natural ou construída do modo de vida. A análise destas representações indicará as formas de expressão da apropriação do lugar pelos indivíduos" (KUHNEN, 2002, p.27).

"As características morfológicas de um lugar são captadas pela percepção em função de particularidades de determinadas operações fisiológicas humanas, assim como das condições ambientais e da estrutura configurativa do espaço. Entretanto a comunicação deste ato perceptivo vai depender também de componentes psicossociais, não tão facilmente detectáveis como os anteriores. Esses irão possibilitar a decodificação das informações que, finalmente, transformam o que se vê em significados" (KUHNEN, 2002, p.28).

Tal esquema funcional torna a percepção humana um fenômeno culturalmente definido. A percepção ambiental, que torna o meio ambiente um produto material e simbólico da ação humana, poderá ser definida como um processo a partir do qual se organiza e interpreta a informação sensorial em unidades significativas para configurar um quadro coerente do entorno ou de uma parte dele. Refere-se à relação do ser humano com o mundo, e há diversas formas de perceber o mundo, desde aquela revestida com o manto da 
sacralização, até aquela ancorada no arcabouço cientificista dominador (MARIN, OLIVEIRA \& COMAR, 2003).

Para Tuan (1980) a percepção é uma somatória de respostas dos sentidos aos estímulos externos com uma atitude proposital que registra claramente certos fenômenos enquanto bloqueia ou obscurece outros, construindo a realidade a partir da experiência, fruto da fusão entre sentimento e pensamento reflexivo.

A construção social de um discurso e de um ideal de "ambiente equilibrado" é, portanto, fundamental para a formação dos comportamentos próambiente desejados. O pensamento simbólico e, por vezes, o mitológico, também ganham grande importância nesse processo, uma vez que são a base da formação das representações sociais sobre o ambiente. A Educação Ambiental tem, portanto, um grande campo de reflexão e ação quando se abre para as dimensões não racionalistas do humano, entendendo a percepção como um fenômeno do existir. A análise fenomenológica parte de um ser humano vivenciando esteticamente seu ambiente, dando-lhe cor e sentidos, associandoIhe nostalgia e mistério (MARIN, OLIVEIRA \& COMAR, 2005).

Quando surgiu o termo Educação Ambiental, foi consenso entre todos os profissionais envolvidos que um de seus principais objetivos é a conscientização. Mas o que pode significar esta palavra senão um processo permanente de ampliação da percepção e compreensão do mundo? Se há concordância que é esse seu objetivo principal, então é preciso ampliar o repertório de maneiras de pensar, para que possam ser incluídos os elementos resultantes das interações entre os diferentes aspectos da realidade e, o que é muito importante, reconhecerse que são essas formas de pensar que modelam nossas ações sobre o mundo. Por outro lado, a maneira de pensar e compreender o mundo estão na mente das pessoas, em seu cérebro. Depende de sua estrutura tanto física como psicológica, tanto social como cultural. Assim, trabalhar a subjetividade é condição essencial da Educação Ambiental (MENDONÇA \& NEIMAN, 2002).

Pode-se perguntar então: quais as experiências de vida e as lembranças mais remotas que tornam um indivíduo sensível às questões ambientais? Quando 
se faz esta mesma pergunta a um número maior de pessoas começam então a surgir uma regularidade de ocorrências nas lembranças e é a partir destas que se concebe a pesquisa em Experiências S ignificativas de Vida.

A sensibilidade ambiental parece ser um dos principais pré-requisitos para o comportamento pró-ambiente. Em outras palavras, pessoas ambientalmente sensíveis, afetuosas à natureza estão em uma condição mais propícia para o desenvolvimento de sua cidadania ambiental, ou possuem a predisposição necessária para o aprender e o educar-se à cerca das questões ambientais (HUNGERFORD \& VOLK, 1990, apud SOARES, 2004). A sensibilidade ambiental é a porta de entrada para uma vida ecologicamente correta. É da sensibilidade que vem a força de nossas ações. Aquilo que nos causa indignação nos mostra ao que somos sensíveis. Assim, se buscamos a cidadania ambiental, então temos que considerar uma educação que propicie o desenvolvimento desta sensibilidade (SOARES, 2004).

Mais do que tentar definir operacionalmente a sensibilidade ambiental como um construto psicológico estudos recentes de Experiências S ignificativas de Vida (SLE do inglês Significative Life Experience) procuraram identificar as experiências de vida que parecem contribuir regularmente para a formação da sensibilidade ambiental (SWARD \& MARCINKOWSKI, 1998, apud SOARES, 2004). Nestes estudos, são feitos a partir de relatos autobiográficos de lideranças no campo ambiental e revelam uma regularidade de certas experiências reportadas como promissoras na formação da cidadania ambiental, isto é, formadoras de indivíduos comprometidos com a causa ambiental.

A lógica para a aplicação e difusão destas descobertas está justamente em estimular a reprodução de tais experiências na Educação Ambiental (EA) a fim de propiciar a emergência da sensibilidade ambiental. Em um grande número de cursos e oficinas de EA podemos encontrar atividades identificadas como sendo exercícios de sensibilização, porém na maioria dos casos elas carecem de embasamento teórico-científico que lhes assegure o potencial sensibilizante do exercício proposto. O significado de uma experiência depende muito do contexto espaço-temporal, do momento que está vivendo o sujeito, da sua história. Em 
outras palavras, não podemos forçar a sensibilização ambiental e não importa qual seja a atividade proposta, não podemos jamais estar certos de que ao fazer tal atividade o educando estará sensibilizado (SOARES, 2004).

Em um estudo com base em relatos autobiográficos envolvendo cerca de 30 pesquisadores de 12 países - sendo que 9 países já publicaram seus resultados - (PALMER et. al.,1998, apud SOARES, 2004), as experiências positivas vividas na infância junto à natureza, sejam elas, pescarias, caçadas, subir em árvores ou as experiências negativas que causavam sensação de perda ou apreensão, e mortandade de peixes, perda de espaços verdes da infância como matas ou campinas, presenciar a morte de animais, lidera os percentuais como os fatores mais influentes da formação de um indivíduo ambientalmente responsável e ativo. Essas pesquisas vão de encontro aos resultados obtidos nos estudos 2 e 3a deste trabalho. A partir da revisão bibliográfica sobre pesquisas de Experiências Significativas de Vida feita por Chawla (1998, apud SOARES, 2004) percebe-se claramente que atividades desenvolvidas ao ar livre, em especial em ambientes de "natureza virgem" ou de exuberância natural, definitivamente contribuem para a consolidação da sensibilidade ambiental. Em uma das pesquisas revisadas, $78 \%$ dos entrevistados identificou a vivência em áreas naturais como o principal fator de influência sobre a decisão de fazer carreira em Biologia da Conservação; noutras duas pesquisas revisadas, mais de $90 \%$ dos entrevistados informou que atividades ao ar livre (férias com a família, brincadeiras de criança, acampamentos da juventude, pescaria e caça) foram decisivos na formação da atitude pró-ambiente (SOARES, 2004). Pesquisas deste tipo têm encontrado sempre o mesmo padrão. Raramente os entrevistados identificam um panfleto ou uma cartilha elaborada por um órgão público como um fator que thes determinou as escolhas pró-ambiente, embora em alguns casos são mencionados personalidades (professores, autores), vídeos ou organizações não governamentais.

Para Padua (1997, p.35) "num processo dinâmico, as condições externas podem influenciar a atitude das pessoas com relação ao meio ambiente. Daí o grande valor de expor as pessoas a um ambiente natural, onde existe a 
oportunidade de aprendizado e sensibilização". O contato direto com a natureza sem o intuito de objetivá-la ou racionalizá-la, pode ser poderoso instrumento de Educação Ambiental.

Como possibilidade de contato direto com a natureza e re-elaboração do imaginário simbólico sobre a paisagem e a territorialidade, o Ecoturismo pode proporcionar o que chamaremos aqui de "Descoberta Ecológica", desde que seja conduzido de modo profissional e os agentes eliciadores das atitudes próambiente possam estar presentes. Deve, para isso, inicialmente deixar de construir e gerir os equipamentos turísticos de modo a transformar as áreas naturais em parques particulares destinadas exclusivamente à obtenção de lucro. As modalidades de turismo de natureza que aparentemente estão mais próximas de uma concepção de sustentabilidade são, por vezes, limitadas pelas estratégias de mercado e políticas públicas que tomam a natureza uma mercadoria valorizada, e transformam as áreas naturais para o exclusivo uso das elites econômicas (LUCHIARI, 2002).

Para Pegoraro (2007) as experiências geradas e vivenciadas em uma atividade educativa ao ar livre, só não se diluem ou se dissipam se os processos capazes de gerar vínculos, continuidade e aprofundamentos reflexivos forem considerados e estabelecidos. Isso implica a necessidade de se conceber mecanismos e providências capazes de "contribuir para a superação da fragmentação dispersiva e do pontualismo estático que ocasiona esgotamento das atividades em si mesmas, de forma que as experiências produzidas possam conduzir a outras experiências e a outras situações qualitativamente crescentes" (PEGORARO, 2007, p.78).

É necessário que a síntese reflexiva, parte importante do processo de construção de novas atitudes interacionistas, seja revestida da dimensão emotiva do humano. Para tanto, as práticas de Educação Ambiental em áreas preservadas que enfatizam um contanto interativo do grupo baseado na aventura e que oferecem pouca oportunidade de reflexão e contemplação, ou que priorizam a informação sobre as espécies observáveis e particularidades de sua biologia, devem ser substituídas por atividades que possibilitem momentos de solidão, 
geradores das situações contemplativas e interações nostálgicas (MARIN, OLIVEIRA, \& COMAR, 2003).

Para Matsushima (1997), educar significa propiciar o florescimento de algo que já está dentro da pessoa em estado nascente, e não encher de conhecimentos um recipiente vazio, estando intimamente relacionada com a valorização e a plenificação das potencialidades inerentes a cada indivíduo, que tornam este um ser único, diferente dos demais e, por isso, importante no todo.

Esta valorização ocorre em uma educação que vê o ser humano de forma integral, estimulando o desenvolvimento harmonioso das dimensões da sua totalidade pessoal: física, mental, emocional e espiritual, preparando-o para participar dos outros planos da totalidade: o comunitário, o social, o planetário e o cósmico (CARDOSO, 1998).

A educação para a vida não é o mero acúmulo de informações, mas vê o educando em sua inteireza, valorizando afetividade, percepções, expressão, sentidos, crítica, criatividade e intuição (MARCHAND, 1985). Envolver os atores sociais que participam da discussão sobre a questão ambiental não tem sido suficiente para a conquista de novos valores. Mais do que conscientizar (campo da "razão") é preciso sensibilizar (universo restrito das "emoções"), questionar o paradigma central do capitalismo, e não apenas adaptá-lo a uma suposta "nova" racionalidade ecológica.

Em Educação Ambiental mais do que realizar conscientização ambiental, termo atrelado a uma idéia transmissão de informações e geração de novos conceitos e conhecimentos, é preciso alcançar-se a sensibilização, uma transposição do enfoque racional na prática educativa para a busca de se atingir a dimensão emotiva, espiritual da pessoa humana na sua interação com a natureza, uma vez que o paradigma dominante da primeira não foi capaz de gerar mudanças comportamentais. Marin, Oliveira, \& Comar (2003) afirmam após analisarem práticas desenvolvidas em vários contextos onde a Educação Ambiental se faz necessária, que são minoria os casos em que se consegue despertar a contemplação, a interatividade nostálgica, a reflexão e a emoção. 
O Ecoturismo, entendido como instrumento de Educação Ambiental que possibilita o contato intenso e dirigido com a natureza, pode contribuir para a construção de representações e significados no imaginário social e transformar a relação do ser humano com o ambiente. A percepção edênica dos destinos ecoturísticos, carregada de simbolismo, remete seus adeptos à busca de um ideal de paisagem onde a ética e a estética têm papel de destaque. Os vínculos com a localidade e com as outras pessoas, renovados sobre uma outra perspectiva, passam a orientar as ações dos sujeitos.

Para Ribon (1991, p.41), ao voltarmos aos locais de beleza natural com o espírito de uma peregrinação, de retorno a um refúgio, descobrimos "aí aquilo que a negligência intelectual de uma cultura nos fizera esquecer: a identidade do eu e do mundo, do sujeito e do objeto, do espírito e da natureza, que um dualismo ilusório separava".

Foi ficando muito evidente, ao longo dos anos em que este trabalho foi realizado, que a concepção do Ecoturismo como um "turismo de destino" (a natureza), deveria ser substituída por uma "forma de fazer turismo", na qual o papel do profissional condutor não se resume a "levar", mas sim a "fazer perceber". O olhar amortecido e distraído do cidadão urbano, que mira mas não vê, precisa ser despertado através da intervenção planejada. O ser humano carrega em seu imaginário, formas de que ele mesmo já sente saudade e "necessita da interação estética com a natureza, com as paisagens paradisíacas, dos vínculos com a bios e do altruísmo e da compaixão para com os seus iguais" (MARIN, OLIVEIRA \& COMAR, 2005, s.p.).

O contato intensificado com a natureza promove o sentimento de pertencimento ao território. "As emoções colorem a experiência humana, até nos mais elevados níveis do pensamento. O despertar para a beleza ambiental constitui intensa surpresa, revelação repentina, independe de opiniões alheias, afeta até quem não se sente ligado à natureza" (QUARANTA-GONÇALVES; GUIMARÃES \& SOARES, 2006, p.6). Desta forma, os destinos ecoturísticos passam a significar lugares presentes na vida dos indivíduos, e não mais aqueles longínquos e misteriosos "paraísos" inaccessíveis. Ou seja, cria-se uma nova 
identidade, um vínculo afetivo entre sujeito e lugar. A territorialidade "não provém do simples fato de viver num lugar, mas da comunhão que com ele mantemos" (SANTOS, 1993, p.62).

Para Schopenhauer (2001, apud MARIN, OLIVEIRA \& COMAR, 2005), a natureza força o ser humano à contemplação estética, que faz com que ele participe da vontade do belo. A natureza teria o poder de prender os sentidos e despertar a imaginação e a nostalgia. Seria a formação desse imaginário de natureza, que a transforma no "refúgio perdido da paz humana" e símbolo da beleza ideal, o principal motivador de fenômenos de mercado como o Ecoturismo? A psicologia ambiental, ao se debruçar sobre o estudo das representações sociais, do simbólico e da construção social do discurso ecológico, pode fornecer elementos para a compreensão morfológica e funcional dos comportamentos próambiente e seus eliciadores? Quanto do imaginário de "paraíso-natural", do "mito criador" de Chauí (2000) está presente no movimento dos cidadãos urbanos em direção à "paz" e ao "descanso" dos parques e reservas observado nos dias atuais e explorado pelo mercado do Ecoturismo?

O Ecoturismo, caso se proponha a se diferenciar dos demais segmentos do turismo (estritamente atrelados aos valores do mercado), a atrelar o contato com a natureza ao pensamento simbólico, a restaurar equilíbrios através do afloramento de comportamentos adaptativos, e não fugir da responsabilidade de construir novos paradigmas a partir de uma nova perspectiva de pensamento, menos linear e mais sistêmico, poderá enfim, conquistar o sucesso tão almejado pelos educadores ambientais. Gostar da natureza pode ser um sentimento afetado por representações sociais, o que reforça a importância de como será conduzido, dirigido, o contato com a natureza em atividades de Ecoturismo. Alguns elementos de sua prática que favorecem a Educação Ambiental são fundamentais: o contato deve ser intenso, deve haver apoio de um grupo (essas atividades devem ser feitas coletivamente), e deve haver superação de barreiras.

As experiências íntimas do corpo com a natureza numa perspectiva subjetiva, para Bruhns (1997, p.136), "expressam em alguns casos uma busca de reconhecimento do espaço ocupado por esse corpo na sua relação com o mundo, 
uma revisão de valores bem como um encontro muito particular do homem com ele mesmo".

Não se pode conceber uma mudança das práticas impactantes da sociedade sobre a natureza se a mesma se apresenta como algo desconhecido, pois "o lugar é a dimensão na qual as pessoas estabelecem a identidade e apropriam-se afetivamente do espaço para vivê-lo, defendê-lo e transformá-lo" (FURLAN, 2000, p.7). Dessa forma, só o contato direto acoplado ao trabalho de construção social de um novo ideário preservacionista pode garantir a eficácia das estratégias educativas. Caso contrário ficaremos relegados à eterna retórica que domina o tema. Não basta levar as pessoas para a frente de um animal, ou um fenômeno natural. O importante é a atitude que se constrói a partir das conversas sobre o tema, as informações que fazem o olhar se modificar, se tornar mais simpático ao que se observa, fazer a decodificação do que está ocorrendo. É preciso acrescentar algo ao que já é espontâneo.

Nas pessoas que tem aversão a natureza, provavelmente existem alguns fatores culturais na história de vida, ou marcos negativos na forma como foi construída a relação com ela, que provoca esse distanciamento. O que se tenta na viagem à natureza é despertar algo que se encontra adormecido, nuns mais noutros menos, mas que está lá. O encontro com uma "natureza boa", ou pelo menos com esse "imaginário" sobre ela, se revelou fator recorrente na conversão dos profissionais pesquisados à causa ambiental, sendo tão importante quanto o exemplo de outras pessoas. O Ecoturismo realizado por bons profissionais reúne essas duas características, desde que esteja aliado a estratégias de Educação Ambiental, e foi nesse sentido que esta pesquisa procurou colaborar.

"Práticas educativas em ambientes ricos em estímulos sensoriais, como as trilhas, criam a oportunidade para seus participantes utilizarem seu corpo encarnado para perceberem o meio ambiente, elaborarem-no e recriarem-no, pelo encadeamento das experiências perceptivas, interagirem e dialogarem com ele, numa relação de troca entre o ambiente e os sujeitos abertos e dados ao mundo; permite também que cada pessoa conheça melhor a si mesma e reconheça e valorize o Outro, o que a torna mais humana" 
(QUARANTA GONÇALVES \& SOARES, 2004, apud QUARANTA-GONÇALVES; GUIMARÃES \& SOARES, 2006, p.7).

O contato com ecossistemas nativos é vital para o ser humano (WILSON, 1994). O que se ganha em vivenciar a natureza é a descoberta de que ela tem regras que não são criadas pelo ser humano. A mais profunda sensação é perceber que o animal não precisa de nós. Ele está bem. Ainda bem que ele nos tolera para que possamos vê-lo. Ele tem milhões de anos de evolução para saber o que fazer, e não precisa que se fique tentando ensiná-lo a copular ou cuidar dos filhotes. É essa percepção de algo a preservar, que faz surgir a vontade de minimizar os impactos da presença humana.

O próprio sentimento preservacionista é um conceito antropocêntrico, uma vez que é o ser humano quem decide o que preservar ou não. Mas, além desse antropocentrismo, há uma percepção mais genuína de que existe uma ordem, e que a mesma é bonita, uma fonte estética. A flor e os animais não sabem que são bonitos. A vantagem do ser humano é que ele tem um olhar capaz de abstrair-se dele mesmo ter uma empatia com a natureza. $E$ na hora que se entra em empatia é que se compreende como ela funciona. Esta é a grande conquista do ser humano.

Os estudos e indícios aqui apresentados nos permitem concluir como verdadeira a hipótese de que as atividades de contato dirigido com a natureza, onde é possível a manifestação de certos comportamentos adaptativos e a reelaboração do imaginário simbólico sobre a paisagem e a territorialidade, podem proporcionar a chamada "descoberta ecológica". Ficou demonstrado, também, que o Ecoturismo, caso promova marcos afetivos gerados pelo contato sensorial e emocional com a natureza, pode introduzir uma grande diferença do ponto de vista motivacional e proporcionar experiências significativas na vida dos indivíduos, promovendo, assim, uma transformação, uma re-Educação Ambiental, no sentido de gerar valores a atitudes pró-ambiente.

Nos permitimos afirmar, por fim, que é preciso reconhecer que quanto mais humanos desejamos ser, menos "racionais" nos devemos tornar. Buscar o 
lado sensível, paulatinamente abandonado desde o iluminismo, parecer ser 0 caminho único possível para nossa re-humanização, por mais paradoxo que isso possa parecer. Podemos, ao reativar nosso lado instintivo, manifestar nossa natureza não cultural. Acreditamos que ela permanece forte e latente em nosso subconsciente. 


\section{6 \\ Referências Bibliográficas}

- ALLEN, J.B. \& FERRAND, J.L. Environmental Locus of Control, Sympathy, and Proenvironmental Behavior: A Test of Geller's Actively Caring Hypothesis. Environment and Behavior, 31, 338-353, 1999.

- Alvarenga L. C. A., NOGUEIRA-FILHO, S. L. G. Escalas de avaliação de sentimentos: um novo instrumento para os projetos de educação ambiental. Textos completos do III Encontro de Pesquisa em Educação Ambiental, Ribeirão Preto, versão em CD-Room, 2005.

- ARAgONÉS, J. I. \& AMÉRIGO, M. Um estudio empírico sobre la actitudes ambientales. Revista de Psicología Social, v.6, 223-240,1991.

- ATTFIELD, R. Environmental ethics and intergenerational equity. Inquiry, v.41, n.2, 207-222, 1998.

- BACHELARD, G. A poética do espaço. São Paulo: Ed. Martins Fontes, 242p., 1993.

- BAHIA, M. C. B. \& SAMPAIO, T. M. V. Na trilha dos sujeitos praticantes do lazer na natureza: um debate conceitual sobre lazer no meio ambiente. Licere. v. 8, no 1. Belo Horizonte: Editora da UFMG, p. 79-92, 2005. 
- BALDASSARE, M., \& KATZ, C. The personal threat of environmental problems as predictor of environmental practices. Environment and Behavior, v.24, 602-616, 1992.

- BARBIER, R. A pesquisa-ação. Brasília: UnB. Tradução de Lucie Didio. 1998.

- BARROS, M. I. A. Outdoor education: uma alternativa para a educação ambiental através do turismo de aventura. In: SERRANO, C. (Org.). A educação pelas pedras: ecoturismo ambiental. São Paulo: Chronos, 2000.

- BECHTEL, R. B. The third revolution in thinking and its impact on Psychology: Medio Ambiente y Comportamiento humano. International Journal of Environmental Psychology, v. 1, 1-7, 2000.

- BECK, U. R isk Society: towards a new modernity. London: Sage, 1993.

- BEDIM, B. P. Turismo e Mudanças Socioculturais em Conceição de Ibitipoca. Monografia (Bacharelado em Turismo) - Departamento de Turismo - UFOP, Ouro Preto, 99p., 2005.

- BETRÁN, J.O. Las Actividades Físicas de Aventura en la Naturaleza: Análise Sociocultural. APUNTS, v.41, p.5-8, Madri, 1995.

- Betrán, J. O. \& BETRÁN, A. O. Proposta pedagógica para as atividades físicas de aventura na natureza (AFAN) na educação física do ensino médio. In: MARINHO, A. \& BRUHNS, H. T. Viagens, lazer e esporte: o espaço da natureza. Barueri: Manole, p. 180 - 210, 2006.

- BOlscho, D., EULEFELD, G., ROST, J., \& SEYBOLD, H. Environmental education in practice in the Federal Republic of Germany: An empirical study. International Journal of Science Education,12,133-146, 1990. 
- BRANDÃO, C. R. 0 ambiente, o sentimento e o pensamento: dez resgates de idéias para pensar as relações entre eles e o trabalho do educador ambiental. In: Cadernos do IV Fórum de Educação Ambiental - I Encontro da rede Brasileira de Educação Ambiental. Rio de Janeiro: INESC, 1997.

- BRANDÃO, C.R. (org) Pesquisa participante. São Paulo: Brasiliense, $3^{\text {a }}$ ed., 1981.

- BRASIL. Secretaria de Educação Fundamental. Parâmetros curriculares nacionais. Brasília: MEC/SEF, 1998.

- BRASIL-MICT/MMA. Diretrizes para uma Política Nacional de Ecoturismo. Brasília, 1994.

- BRÜGGER, P. Educação ou Adestramento Ambiental? Florianópolis: Editora Argos, 2004.

- BRUHNS, H. T. Esporte e natureza: o aprendizado da experimentação. In: SERRANO, C. (org). A educação pelas pedras: ecoturismo e educação ambiental. São Paulo: Chronos, p.25-46., 2000.

- BRUHNS, H.T. O corpo visitando a natureza: possibilidades de um diálogo crítico. In: SERRANO, C.M.T. \& BRUHNS, H.T (Org) Viagens à natureza: turismo, cultura e ambiente. Campinas: Papirus, 1997.

- CAPRA, F. A teia da vida: uma nova compreensão científica dos sistemas vivos. São Paulo: Cultrix, 6ª . Ed., 2001.

- CAPRA, F. As conexões ocultas: ciência para uma vida sustentável. São Paulo: Cultrix, 2002.

- CAPRA, F. O Ponto de Mutação. São Paulo: Ed.Cultrix,1995.

- CARdoso, C. M. A canção da inteireza: Uma visão holística da educação. São Paulo: Summus Editorial. 1998. 
- CARNEIRO, M. J. \& KASTENHOLZ, E. O potencial papel da interpretação na Educação Ambiental dos ecoturistas: o caso do Parque Nacional da Peneda-Gerês (Portugal). In: PEDRINI, A de G. (Org.) Ecoturismo e Educação Ambiental. Rio de Janeiro: Publit, 2005, p. 30-47.

- CARVALHO, I. C. M. A invenção ecológica: narrativas e trajetórias da educação ambiental no Brasil. Porto Alegre: Editora da UFRGS, 2001.

- CASCINO, F. Pensando a relação entre Educação Ambiental e Ecoturismo. In: VASCONCELOS, F.P. (org.). Turismo e Meio Ambiente. Fortaleza: Ed. FUNECE, v.3, p.265-279, 1999.

- CASTORIADIS, C. Feito e a ser feito: as encruzilhadas do labirinto V. Rio de Janeiro: DP\&A, 1999..

- CASTRO, P. Cultura científica e percepção do papel da ciência em matérias ambientais: Portugal no contexto da União Europeia. In: LIMA, L. (org.) Ambiente e Desenvolvimento. Lisboa: Imprensa de Ciências Sociais, 2003.

- Ceballos-lascuráin, H. O ecoturismo como um fenômeno mundial. In: LINDBERG, K. \& HAWKINS, D.E. Ecoturismo: um guia para planejamento e gestão. São Paulo: Editora SENAC, p.23-29, 1995.

- CHAN, R., Environmental attitudes and behavior of consumers in China: Survey findings and implications. Journal of International Consumer Marketing, v. 11, № 4, 25-52, 1999.

- CHAUÍ, M. Brasil: mito fundador e sociedade autoritária. São Paulo: Fundação Perseu Abramo, 2000.

- CORNELL, J. Listening to Nature: how to deepen your awareness of nature. Nevada City: Dawn Publications, 1987.

- CORNELL, J. Sharing the joy of nature: nature activities for all ages. Nevada City: Dawn Publications, 1989. 
- corraliza, J. A. \& BeRENGUER, J. Environmental Values, Beliefs, and Actions: A Situational Approach. Environment and Behavior, 32, 832$848,2000$.

- CORRAL-VERDUGO, V. A Structural Model of Proenvironmental Competency. Environment and Behavior, 34; 531-549, 2002.

- CORRAL-VERDUGO, V.; VARELA-ROMERO, C. \& GONZÁLEZLOMELÍ, D. 0 papel da psicologia ambiental na promoção de competencia pró-ambiental. In: TASSARA, E. T. O.; RABINOVICH, E. P. \& GUEDES, M. C. (eds). Psicologia e Ambiente. São Paulo: Educ, 41-57, 2004.

- COSTA, N. M. C. \& COSTA, V. C. E ducação Ambiental pelo E coturismo em Unidades de Conservação: uma proposta efetiva para o Parque Estadual da Pedra Branca (PEPB) - RJ. In: PEDRINI, A de G. (Org.) E coturismo e Educação Ambiental. Rio de Janeiro: Publit, 2005, p. 48, 64.

- CRESPO, S. \& LEITÃO, P. O que o brasileiro pensa da ecologia. Rio de Janeiro: MAST-CNPq/CETEM-CNPq/Agência do Estado/ISER, 1993.

- DARLEY, J. M., \& GILBERT, D. T. Social psychological aspects of Environmental Psychology. In: LINDZEY, G. \& ARONSON, E. (orgs.). The handbook of Social Psychology, vol. I (3a ed., p. 949-992). Nova York: Random House. 1985.

- DEL PORTO, J. A; LARANJEIRAS, R. R. e MASUR, J. Escalas de autoavaliação de estados subjetivos: Influência das instruções. Jornal Brasileiro de Psiquiatria, 32: 87-90,1983.

- DEL RIO, V. \& OLIVEIRA, L. (orgs.) Percepção Ambiental: a experiência brasileira. São Paulo: Universidade de São Carlos-SP/Studio Nobel, 1997.

- DEMO, P. Metodologia científica em ciências sociais. São Paulo: Atlas, $2^{\mathrm{a}}$ ed., 1992. 
- DENG, J.; WALKER G.J. \& SWINNERTON, G. A comparison of environmental values and attitudes between chinese in canada and anglocanadians. Environment and Behavior, 38, 22-47, 2006.

- DIAS, G. F. Educação Ambiental: princípios e práticas. São Paulo: Editora Gaia, 400p, 1993.

- DIEGUES, A C. S. Desenvolvimento sustentável ou sociedades sustentáveis: da crítica dos modelos aos novos paradigmas. In: DIEGUES, A C. S. Ecologia Humana e planejamento em águas costeiras. São Paulo, NUPAUB, 1996.

- DIEGUES, A. C. 0 mito moderno da natureza intocada. São Paulo: Hucitec, 1992.

- DISPOTO, R. Interrelationships among measures of environmental activity, emotionality and knowledge. Educational and Psychological Measurement, v.37, Summer, 451-459, 1977.

- DORST, J. Antes que a Natureza Morra. São Paulo, Editora Edgard Blücher, 1973.

- DOUGLAS, M., \& WILDAVSKY, A. Risk and culture: an essay on the selection of technological and environmental dangers. Berkeley: University of California Press, 1982.

- DUNLAP, R. E. Environmental sociology: a personal perspective on its first quarter century. Organization and Environment, v. 15, 10-29, 2002.

- DUNLAP, R. E. From environmental to ecological problems. In: CALHOUN, C. \& RITZER, G. (orgs.). Social problems (pp. 707-738). Nova York: McGraw-Hill, 1993.

- DUNLAP, R. E., \& VAN LIERE, K. D. The 'new environmental paradigm': a proposed measuring instrument and preliminary results. Journal of Environmental Education, v. 9, 10-19. 1978. 
- $\quad$ DUNlaP, R. E., VAN LIERE, K. D., MERTIG, A. G., \& JONES, R. E. Measuring endorsement of the New Ecological Paradigm: a revised NEP scale. Journal of Social Issues, 56, 425-442, 2000.

- FARIA, M. O. \& GARCIA, E. B. Um sonho e um trabalho para a construção de outro futuro. In: NEIMAN, Z. 2002 (ORG). Meio Ambiente, Educação e Ecoturismo. Barueri:Ed. Manole, p.109-133, 2002.

- FARIA, M. O. 0 mundo globalizado e a questão ambiental. In: NEIMAN, Z. 2002 (ORG). Meio Ambiente, Educação e Ecoturismo. Barueri:Ed. Manole, p.3-15, 2002.

- farina A. \& BElgRANO, A. The eco-field: A new paradigm for landscape ecology. Ecological Research, v.19, n.1, 107-110, 2004.

- FERREIRA, L. C. Os ambientalistas, os direitos sociais e o universo da cidadania. In: FERREIRA, L. C. \& VIOLA, E. (orgs.), Incertezas da sustentabilidade na globalização. Campinas: Ed. UNICAMP, p.241-277, 1996.

- FERREIRA, L. C. Sustentabilidade: uma abordagem histórica da sustentabilidade. In: FERRARO JR, L. A. Encontros e caminhos: formação de educadores(as) ambientais e coletivos educadores. Brasília, MMA/DEA, 2005.

- FERREIRA, L.F. \& COUTINHO, M.C.B.. Educação ambiental em estudos do Meio: a experiência da Bioma. In: SERRANO, C. A Educação pelas Pedras: ecoturismo e educação ambiental. São Paulo:Chronos, 2000.

- FINGER, M. From knowledge to action? Exploring the relationships between environmental experiences, learning, and behavior. Journal of Social Issues, 50,141-160, 1994.

- FURLAN, S. A. Lugar e Cidadania: implicações socioambientais das políticas de conservação ambiental (situação do Parque Estadual de Ilha Bela na llha de São Sebastião - SP). Tese de doutorado, USP - São Paulo: FFLCH - Depto. de Geografia. Volumes I e II. (fotocópia), 2000. 
- GIDDENS, A. Modernity and Self-identity. Cambridge: Polity Press, 1991.

- GIDDENS, A. Risk Society: the Context of British Politics. In: Franklin, Jane (ed) The Politics of R isk Society. Cambridge: Polity Press, 1998.

- GIGLIOTTI, L. M. Environmental education: What went wrong? What can be done? Journal of Environmental Education, 22, 9-12,1990.

- GOMES, P. M. (E co)Turismo: uma (Re)Leitura dos Discursos. Brasília: IBAMA, 2003.

- GONZALEZ-GAUDIANO, E. E ducação Ambiental para a biodiversidade: conceitos e práticas. In: JUNQUEIRA, V. \& NEIMAN, Z. Educação Ambiental e Conservação da Biodiversidade: reflexões e experiências brasileiras. Barueri: Manole, p. 3-16, 2007.

- gRupo de tRabalho de educaÇÃo amBiental das ORGANIZAÇÕES NÃO-GOVERNAMENTAIS NO FÓRUM GLOBAL. Tratado de educação ambiental para sociedades sustentáveis e responsabilidade local. Rio de Janeiro, 1992.

- GUIMARÃES, F.S.; ZUARDI, A.W.; GENTIL, V. \& GRAEFF, F.G. A importância do treinamento prévio em escala analógica de autoavaliação. Revista ABAP-APAL, v.10, p.5-7, São Paulo, 1988.

- GUIMARÃES, M. Dimensão ambiental na educação. Campinas: Papirus, 1995.

- GUIMARÃES, S. T. de L. Dimensões da percepção e interpretação de meio ambiente: vislumbres e sensibilidades das vivências na natureza. In: Percepção e Conservação Ambiental: a interdisciplinaridade no estudo da paisagem. OLAM - Ciência \& Tecnologia, vol.4, n. 1, abr., p. 46-64, Rio Claro: Aleph Engenharia \& Consultoria Ambiental Ltda., 2004. 
- GUIMARÃES, S. T., Trilhas Interpretativas e Vivências na Natureza: reconhecendo e reencontrando nossos elos com a paisagem. In: Anais do Io Congresso Brasileiro de Planejamento e Manejo de Trilhas. Rio de Janeiro, 2006.

- HANNIGAN, J. Environmental Sociology. London : Routledge, 1995.

- HEATH, Y. \& GIFFORD, R. Free-Market Ideology and Environmental Degradation: The Case of Belief in Global Climate Change. Environment and Behavior, 38, 48-71, 2006.

- HEIMSTRA, N.W.; \& McFARLING, L.H. Psicologia ambiental. São Paulo: EPU/EDUSP, 1978.

- HERNÁNDEZ, B., SUÁREZ, E., MARTíNEZ-TORVISCO, J. \& HESS, S. The Study of Environmental Beliefs by Facet Analysis: Research in the Canary Islands, Spain. Environment and Behavior, 32, 612-636, 2000.

- HUMPHRIES, T.L. Effectiveness of Dolphin-Assisted Therapy as a behavioral intervention for young children with disabilities. Bridges, v.1, n.6, p.1-9, 2003.

- INGLEHART, R. The silent revolution: changing values and political styles among western publics. Princeton, Nova York: Princeton University Press. 1977.

- IRVING, M.A. Educação Ambiental como premissa ao desenvolvimento do ecoturismo. In: VASCONCELOS, F.B. (org.). Turismo e Meio Ambiente. Fortaleza: UECE, v.3, p.13-21,1997.

- JACOBS, M. The Green Economy. London: Pluto Press, 1991.

- JACOBSON, S.K \& PÁDUA, S. M. Pupils and parks-environmental education in national parks of developing countries. Journal of the association for childhood education international. v.68, n.5, 290-293, 1992. 
- JESUS, G. M. A leviana territoriedade dos esportes de aventura: um desafio à gestão do ecoturismo. In: MARINHO, A. \& BRUHNS, H. T. Turismo, Lazer e Natureza. Barueri: Manole, 2003.

- JOHNSON, C.Y., BOWKER, J. M. \& CORDELL, H. K. Ethnic Variation in Environmental Belief and Behavior: An Examination of the New Ecological Paradigm in a Social Psychological Context. Environment and Behavior. 36; 157-186, 2004.

- JUNQUEIRA, V. \& NEIMAN, Z. Educação Ambiental e Conservação da Biodiversidade: reflexões e experiências brasileiras. Barueri: Manole, 318p., 2007.

- KALS, E.; SCHUMACHER, D. \& MONTADA, L. Emotional Affinity toward Nature as a Motivational Basis to Protect Nature. Environment and Behavior, 31, 178-202, 1999.

- KELLERT, S. The biological basis for human values of nature. In: KELLERT, S.\&. WILSON, E (Eds.). The biophilia hypothesis. Washington, DC: Island Press, 42-69, 1993.

- KINKER, S. Ecoturismo e conservação da natureza em parques nacionais. 2 ed. Campinas, Papirus, 2005.

- KRAUSE, D. Environmental consciousness: an empirical study. Environment and Behavior, v. 25, 126-142, 1993.

- KRIPPENDORF, J. Sociologia do Turismo: para uma nova compreensão do lazer e das viagens. São Paulo:Ed. Civilização Brasileira, 1989.

- KUHNEN, A. Representações sociais e meio ambiente: Estudo das transformações, apropriações e modos de vida na Lagoa da Conceição Florianópolis/SC. Tese apresentada ao Programa de Doutorado Interdisciplinar em Ciências Humanas - Sociedade e Meio Ambiente do Centro de Filosofia e Ciências Humanas da Universidade Federal de Santa Catarina, 2002. 
- LADISLAU, C. R. Lazer na natureza: um diálogo de espelhos. In: 11ำ ENAREL - Encontro Nacional de Recreação e Lazer. Foz do Iguaçu, 1999. Coletânea. Cascavel: Assoesste, 1999.

- LAWREnCE, R. J. Ecologia Humana. In: TASSARA, E. T. O.; RABINOVICH, E. P. \& GUEDES, M. C. (eds). Psicologia e Ambiente. São Paulo: Educ, 263-303, 2004.

- LEAL-FILHO, W. A Educação Ambiental Aplicada ao Turismo: experiências da Costa de Caparica, Portugal. In: PEDRINI, A de G. (Org.) Ecoturismo e Educação Ambiental. Rio de Janeiro: Publit, 2005, p. 23-29.

- LEFF, E. (org.). La complejidad ambiental. México: PNUMA/Siglo Veintiuno Editores, 2000.

- LEFF, E. Ciencias Sociales y formación ambiental. Barcelona: Editorial Gedisa, 1994.

- LEFF, E. Saber ambiental: sustentabilidad, complejidad, poder. México:Siglo Veintiuno Editores/Unam/PNUMA, 1998b.

- LEFF, E. Ecologia y capital; racionalidad ambiental, democracia participativa y desarrollo sustentable. 3.ed. México:Siglo Veintiuno Editores/Unam, 1998a.

- LEIS, H. R. Meio Ambiente, Ética e Religião na Sociedade Contemporânea. São Paulo: Ed. Gaia, 1998.

- LEVINSON, B.M. Psicoterapia infantil asistida por animales. Barcelona, Fundacion Purina: Fondo Editorial. 1995

- LI, B. L. Why is the holistic approach becoming so important in landscape ecology? Landscape and Urban Planning, v.50, n.1, 27-41, 2000.

- LI, L. Y. Effect of collectivist orientation and ecological attitude on actual environmental commitment: The moderating role of consumer demographics and product involvement, Journal of International Consumer Marketing, v.9, n.4, 31-53, 1997. 
- LORENZ, K. Evolution and modification of behavior. Chicago: The University of Chicago Press, 1965.

- LOUREIRO, C. F. B. et al. Educação Ambiental e Gestão Participativa em Unidades de Conservação. Rio de Janeiro, IBAMA, 60 p., 2005.

- LUCHIARI, M. T. D. P. A mercantilização das paisagens naturais. In: BRUHNS, H. T., GUTIERREZ, G. L. (orgs.). Enfoques contemporâneos do lúdico: III ${ }^{\circ}$ ciclo de debates lazer e motricidade. Campinas: Autores Associados / Comissão de Pós-Graduação da Faculdade de Educação Física da Unicamp, 2002.

- LUSTOSA, M.G.L., MATOS, M.C.F.G., \& LOUREIRO, C.F.B. 0 estado da arte da Educação Ambiental brasileira a partir do $\bigvee$ o Fórum Brasileiro de Educação Ambiental: agentes sociais e problemáticas. In: Anais do IV Encontro de Pesquisas em Educação Ambiental. Rio Claro, 2007.

- LYONS, E. \& BREAKWELL, G.M. Factors predicting environmental concern andin difference in 13-to-16-year-olds. Environment and Behavior, $\underline{26}, 223-238,1994$.

- MALONEY, M. \& WARD, M. Ecology: Let's hear from the people: An objective scale for the measurement of ecological attitudes and knowledge, American Psychologist, July, 583-586,1973.

- MAlONeY, M. P., WARD, M. P., \& BRAUCHT, G. N. Psychology in action: a revised scale for the measurement of ecological attitudes and knowledge. American Psychologist, v. 30, 787-790, 1975.

- MARCHAND, M. A afetividade do educador. São Paulo: Summus Editorial, 1985.

- MARIN, A. A., OliveiRA, H. T. \& COMAR, M. V. A Educação Ambiental num contexto de complexidade do campo teórico da percepção. Interciencia INCI, v.28 n.10, 616-619, Caracas oct. 2003. 
- MARIN, A. A. ; OLIVEIRA, H. T. \& COMAR, M. V. Percepção ambiental, imaginário e práticas educativas. Textos completos do III Encontro de Pesquisa em Educação Ambiental, Ribeirão Preto, versão em CD-Room, 2005.

- MARTIN, B. E SIMINTRAS, A. The impact of green product lines on the environment: Does what they knowaffect how they feel?. Marketing Intelligence and Planning, v. 13, 끄. 4, 16-23, 1995.

- MARTINS, J. Psicologia da cognição. In: MARTINS, J.; DICHTCHEKENIAN, M. F. S. F. B. Temas fundamentais de fenomenologia. São Paulo: Moraes, p. 75-87, 1984.

- MARTINS, M.F. Zooterapia ou terapia assistida por animais (TAA), Revista Nosso Clínico, v.40, p.22-26, 2004.

- MATSUSHIMA, K. Dilema contemporâneo e educação ambiental: uma abordagem arquetípica e holistica. Brasilia: Aberto, v.10, 1997.

- MATSUSHIMA, K. Perspectiva arquetípica e holística em Educação Ambiental: fundamento, vivência e prática. São Paulo. Tese de Doutorado apresentada ao Instituto de Psicologia da Universidade de São Paulo, 1992.

- Maturana, H. Cognição, Ciência e Vida Cotidiana. Belo Horizonte: UFMG, 2001

- MEIRA, P. \& SATO, M. Só os peixes mortos não conseguem nadar contra a correnteza. Revista de Educação Pública, v. 14, n. 25, 17-31, 2005.

- MENDONÇA, R. A experiência na natureza segundo J oseph Cornell. In: SERRANO, C. (Org.). A educação pelas pedras: ecoturismo e educação ambiental. São Paulo: Chronos, p. 135-154, 2000. 
- MENDONÇA, R., \& NEIMAN. Z. À sombra das árvores: transdisciplinaridade e educação ambiental em atividades extraclasse. São Paulo: Chronos, 2003.

- MENEZES, L. N.; CORIOLANO, T. O Ecoturismo e os hóspedes da natureza. In: BARRETO, M.; TAMANINI, E. (org.). Redescobrindo a ecologia no turismo. Caxias do Sul: EDUCS, 2002.

- MERGUlHÃO, M. C. Zoológico: uma sala de aula viva., Dissertação (Mestrado). São Paulo: Faculdade de Educação, Universidade de São Paulo, 1998.

- MERleAU-PONTY, M. Fenomenologia da Percepção. São Paulo: Martins Fontes, 1999 (obra original em Francês, 1945).

- MILFONT, T.L., DUCKITT, J. \& CAMERON, L.D. A Cross-Cultural Study of Environmental Motive Concerns and Their Implications for Proenvironmental Behavior. Environment and Behavior, 38, 745-767, 2006.

- MOL, A.P.J. The refinement of production. In: REDCLIFT, M. e WOODGATE, G. (eds.), The sociology of the environment, v.1, Aldershot,UK: Elgar Reference Collection, p.138-149, 1997.

- MOL, A.P.J.; \& SPAARGAREN G. Ecological Modernization Theory in Debate: A Review. Environmental Politics. Spring. v.9, nำ1, 2000.

- MONTAlvOR, L. \& SIMÕES, J. G. (eds.) Poemas de Alberto Caeiro. 1ª edição. Lisboa: Ática (Obras Completas de Fernando Pessoa, III), 1946.

- MORIN, E. Introdução ao Pensamento Complexo. Lisboa: Instituto Jean Piaget, 2001.

- NEIMAN, Z, 2005 . Natureza e cultura brasileiras: matérias primas do Ecoturismo. In NEIMAN, Z. \& MENDONÇA, R. (orgs). E coturismo no Brasil. Barueri: Ed. Manole, 2005.

- NEIMAN, Z. \& MENDONÇA, R. Ecoturismo: discurso, desejo e realidade. Turismo em Análise, V.12, n², 98-110. São Paulo, 2000. 
- NeIMAN, Z. \& MOTTA, C. P. Educação Ambiental. São Paulo: Ed. Atual, (4 vol.), 1991.

- NEIMAN, Z. \& RABINOVICI, A. O cerrado como instrumento para Educação Ambiental em atividades de ecoturismo. In: NEIMAN, Z. (org). Meio ambiente, educação e ecoturismo. Barueri: Manole, 2002.

- NOONEY, J.G., WOODRUM, E., HOBAN, T.J. \& CLIFFORD, W.B.. Environmental Worldview and Behavior: Consequences of Dimensionality in a Survey of North Carolinians. Environment and Behavior, 35, 763-783, 2003.

- NORD, M., LULOFF, A. E. \& BRIDGER, J.C. The Association of Forest Recreation with Environmentalism. Environment and Behavior, 30; 235-246, 1998.

- NORDLUND, A.M. \& GARVILL, J. Value Structures behind Proenvironmental Behavior. Environment and Behavior, 34, 740-756, 2002.

- NORRIS, H. The Action of Sedatives on Brain Stem Oculomotor Systems in Man. Neuropharmacology, 10:181-191,1971.

- ORGANIZAÇÃO DAS NAÇÕES UNIDAS, Programa das Nações Unidas para o Meio Ambiente (PNUMA),. Cuidando do Planeta Terra: uma estratégia para o futuro da vida. São Paulo: União Internacional para a Conservação da Natureza (UICN) \& Fundo Mundial para a Natureza (WWF), 1991.

- PADUA, S. M. Educação ambiental como um instrumento de integração entre conservação e uso sustentável dos recursos naturais: o caso do Pontal do Paranapanema, São Paulo. Tese de doutorado, 180 p., UnB-CDS, Doutorado em Política e Gestão Ambiental, 2004.

- PADUA, S. M. . Uma pesquisa em educação ambiental: a conservação do mico-leão-preto (Leontopithecus chrysopygus). In: VALLADARESPADUA, C.; BODMER, R. \& CULLEN Jr., L. (orgs.). Manejo e Conservação 
de Vida Silvestre no Brasil. Brasília: MCT - CNPq e Sociedade Civil Mamirauá, p. 34-42,1997.

- PADUA, S. M. Educação Ambiental e Participação Comunitária: chaves para a conservação da biodiversidade. In: Empreendedores sociais em ação. ROURE, M \& PADUA, S. (orgs.). São Paulo: Cultura Editores, p.183201, 2001.

- PADUA, S. M. Educação Ambiental: um caminho possível para mudanças. In: MEC (org.). Reflexões sobre o panorama da educação ambiental no ensino formal. Brasília: COEA, MEC, 28 e 29 de fevereiro, 2000.

- PAGANI, M. I. et al. As trilhas interpretativas da natureza e o ecoturismo. In: LEMOS, A.I.G. (Org.). Turismo: impactos socioambientais. São Paulo: Hucitec, p.45-59, 1996.

- PEDRINI, A. G. A Educação Ambiental no Ecoturismo Brasileiro: Passado e Futuro. In: SEABRA, G. (Org.) Turismo de Base Local; identidade cultural e desenvolvimento regional. João Pessoa, Ed. Universidade Federal da Paraíba, 2007, p. 249-260.

- PEDRINI , A. G. Educação Ambiental para o Desenvolvimento ou Sociedade Sustentável?: uma breve reflexão para a América Latina. Educação Ambiental em Ação, v.17, 2006a.

- PEDRINI, A. G. Avaliação da Educação Ambiental no Ecoturismo (com Trilhas): Uma Proposta Metodológica de Qualidade Conceitual. Revista OLAM - Ciência e Tecnologia , Rio Claro (SP), v. 7, n. 2, p. 83-106, dez/2006b.

- PEDRINI, A. G. Em busca da Educação Ambiental no (Eco)turismo brasileiro. In: ENCONTRO INTERDISCIPLINAR DE ECOTURISMO EM UNIDADES DE CONSERVAÇÃO, 1, Anais..., 3 a 7 de outubro de 2005. 
- PEDRINI, A. G. Trajetórias em Educação Ambiental. In: PEDRINI, A. G. (Org.) Educação Ambiental; Reflexões e Práticas Contemporâneas. 5 ed. Petrópolis: Vozes, 2002, p. 21-87.

- PEDRINI, A de G.; TORGANO, M. F. Ecoturismo com Educação Ambiental: discursos e práticas. In: PEDRINI, A de G. (Org.) Ecoturismo e Educação Ambiental. Rio de Janeiro: Publit, 2005, p. 13-38.

- PEgoraRO, J.L. Programas educativos junto à "natureza" e a educação ambiental. In: Anais do IV Encontro de Pesquisa em Educação Ambiental. Rio Claro:USP/UNESP/UFSCar, 2007.

- PELLetieR, L.G., LEGAULT, L.R. \& TUSON, K.M. The Environmental Satisfaction Scale: A Measure of Satisfaction with Local Environmental Conditions and Government Environmental Policies. Environment and Behavior, 28, 5-26, 1996.

- PIRES, P. dos S. Ecoturismo no Brasil: uma abordagem histórica e conceitual na perspectiva ambientalista. Tese (Doutorado), FFLCH, Universidade São Paulo, São Paulo, 1998.

- QUARANTA GONÇALVES, M. L.; SOARES, M. L. de A. Uma interface entre a educação ambiental e a fenomenologia da percepção. In: Encontro de Pesquisadores e de Iniciação Científica da Universidade de Sorocaba, 7., 2004, Sorocaba, SP. Resumos. Sorocaba, SP: Uniso, p. 107-108, 2004.

- QUARANTA-GONÇALVES, M. L; GUIMARÃES S. T. L. \& SOARES, M. L. A. Uma aplicação da fenomenologia de Merleau-Ponty e da geografia humanística de Tuan a um trabalho educativo de percepção ambiental em trilhas. Anais do o Congresso Nacional de Planejamento e Manejo de Trilhas. Rio de Janeiro: UERJ, nov. 2006.

- RABINOVICI, A. Articulações e parcerias entre Organizações NãoGovernamentais (ONGs) e Unidades de Conservação (UCs). In: NEIMAN, Z. 2002 (ORG). Meio Ambiente, Educação e Ecoturismo. Barueri:Ed. Manole, p.41-71, 2002. 
- RASteiRO, M. A. Espeleoturismo: Conceitos básicos. In. Informativo SBE o 80, p.5. Campinas:Sociedade Brasileira de Espeleologia, 2002.

- REIGOTA, M. Desafios à Educação Ambiental escolar. In: CASCINO, F.; JACOBI, P.; \& OLIVEIRA, J. F. (orgs). Educação, meio ambiente e cidadania: reflexões e experiências. São Paulo: SMA/CEAM, p.33-42, 1998.

- REIGOTA, M. O Estado da arte da pesquisa em educação Ambiental no Brasil . Pesquisa em Educação Ambiental, Vol. 2, no 1, p.33-66, 2007.

- REQUIXA, R. Sugestões de diretrizes para uma política nacional de lazer. São Paulo: SESC, 1980.

- RIBON, M. A arte da natureza. Campinas, SP: Papirus, 1991.

- RISSER, P.G. Toward a Holistic Management Perspective. BioScience, v. 35, n.7, Managing Stressed Ecosystems, 414-418, 1985.

- RODRigues, A. B. Ecoturismo: limites do eco e da ética. In: RODRIGUES, A. B. (Org.) Ecoturismo no Brasil: possibilidades e limites. São Paulo: Contexto, 2003, p. 29-46.

- SACHS, I. Desenvolvimento numa economia mundial liberalizada e globalizante: um desafio impossível? Estudos Avançados v.11, № 30, p.213-242. São Paulo, 1997.

- SAFATLe, A. A medida certa. Revista Página 22, vol.4, (dez 2006 - jan 207): FGV-CES, p. 20-27, 2006.

- SALVATI, S. S. Interpretação Ambiental. In: MITRAUD, S. (Org.) Manual de Ecoturismo de Base Comunitária: ferramentas para um planejamento responsável. Brasília: WWF, 2003.

- SAN JOAQUÍN, M.P.Z. Terapia asistida por animales de conpañia. Bienestar para el ser humano, Temas de hoy, p.143-149, 2002.

- SANTOS, M. O espaço do cidadão. São Paulo:Nobel, 1993. 
- SCHAHN, J. \& HOLZER. E. Studies of individual environmental concern. Environment and Behavior, 22, 767-786,1990.

- SCHWARTZ, G. M.; SILVA, R. L. Lazer, turismo, ecologia: contribuições para uma nova atitude. In: 11ํ ENAREL - Encontro Nacional de Recreação e Lazer. Foz do Iguaçu, 1999. Coletânea. Cascavel: Assoesste, 1999.

- SEABRA, G. F. Ecos do Turismo: o turismo ecológico em áreas protegidas. Campinas, SP: Papirus, 2001.

- SERRANO, C. A educação pelas pedras: uma introdução. In: SERRANO, C. (org). A educação pelas pedras: ecoturismo e educação ambiental. São Paulo: Chronos, p.07-24, 2000.

- SERRANO, C. Uma introdução à discussão sobre Turismo, Cultura e Ambiente. In: SERRANO, C. \& BRUHNS, H. T. (orgs). Viagens à natureza: turismo, cultura e ambiente. Campinas, SP: Papirus, p.11-25, 1997.

- SIMMONS, D. A. Are we meeting the goal of responsible environmental behavior? An examination of nature and Environmental Education Centers goals. Journal of Environmental Education, ํㅜ 22, 16-21, 1991.

- SOARES, F. J. Caminhos para o desenvolvimento da sensibilidade ambiental: uma incursão sobre as evidências. Projeto - Revista de Educação, v. 6, n. 8, 5-9, Porto Alegre, 2004.

- SOARES, M. E. Concepções de ambiente e educação ambiental em professores de Ciências: múltiplos significados. Dissertação (Mestrado) Faculdade de Educação - UFMG, Belo Horizonte. 1998.

- SORRENTINO, M. De Tbilisi a Thessaloniki. A Educação Ambiental no Brasil. In: CASCINO, F.; JACOBI, P.; \& OLIVEIRA, J. F. (orgs). Educação, meio ambiente e cidadania: reflexões e experiências. São Paulo: SMA/CEAM, p.43-52, 1998. 
- STAPP, W. B.; BENNETT, D. BRYAN, W.; FULTON, J. McGREGOR, J.; NOWAK, P. WAN, R. E HACLICK, S. The concept of Environmental Education. Journal of Environmental Education, no 1, 30-31, 1969.

- STEG, L., \& SIEVERS, I. Cultural theory and individual perceptions of environmental risks. Environment and Behavior, 32, 250-269, 2000.

- STERN, P. C., DIETZ, T., \& GUAGNANO, G. A. The new ecological paradigm in social-psychological context. Environment and Behavior, 27, 723-743, 1995.

- TANNER, R. T. Educação Ambiental. Traducão SCHLESINGER, G. São Paulo: SUMUS/EDUSP, 1978.

- THOMPSON, S. C. G., \& BARTON, M. A. Ecocentric and anthropocentric attitudes towards the environment. Journal of Environmental Psychology, 4, 149-157, 1994.

- TILBURY, D. Environmental Education for sustainability: defining the news focus of environmental education in the 1990s, Environment education research: Bath, 1995.

- TUAN. Y. Espaço e lugar: a perspectiva da experiência. Tradução de Lívia de Oliveira. São Paulo: Difel, 1983.

- TUAN. Y. Topofilia: um estudo da percepção, atitudes e valores do meio ambiente. São Paulo: Difel, 1980.

- UZZEL, D. A psicologia ambiental como uma chave para mudar atitudes e ações para com a sustentabilidade. In: TASSARA, E. T. O.; RABINOVICH, E. P. \& GUEDES, M. C. (eds). Psicologia e Ambiente. São Paulo: Educ, 363-388, 2004.

- VAN LIERE, K. D., \& DUNLAP, R. E. Environmental concern: does it make a difference how it's measured? Environment and Behavior, 13, 651676, 1981. 
- VASCONCELLOS, J. Trilhas interpretativas como instrumento de educação. In: Curso de Atividades Ecológicas II: Trilhas Interpretativas. Unilivre: Curitiba, 1997.

- VASCONCELLOS, M. M. N. E ducação Ambiental: Ponte entre diferentes áreas do conhecimento. In: Anais do 7ํㅡㄹ Encontro Perspectiva do Ensino de Biologia, p.84-86, Coletânea. São Paulo: FEUSP, 2000.

- VIEZZER, M. L. \& OVALLES, O. Manual Latino-Americano de Educ-Ação Ambiental. São Paulo: Editora Gaia,1995.

- VILLACORTA, M., KOESTNER, R. \& LEKES, N. Further Validation of the Motivation Toward the Environment Scale. Environment and Behavior, 35, 486505, 2003.

- VINING, J. Environmental emotions and decisions. Environment and Behavior, 24, 3-34. 1992.

- VIOLA, E. J.; LEIS, H. R. A evolução das políticas ambientais no Brasil, 19711991: do bissetorialismo preservacionista para o multissetorialismo orientado para o desenvolvimento sustentável. In: HOGAN, P. J.; VIEIRA, P. F. (Orgs.) Dilemas socioambientais e desenvolvimento sustentável. Campinas: EDUNICAMP, p. 73102, $2^{\mathrm{a}}$ ed. 1995.

- WEIGEL, R., \& WEIGEL, J. Environmental concern: the development of a measure. Environment and Behavior, 10, 3-15. 1978.

- WELLS, M. \& BRANDON, K. (eds). People and Parks: linking protected areas with local communities. Washington DC: Banco Mundial, WWF, USAID, 1992.

- WIIDEGREN, Ö. The New Environmental Paradigm and Personal Norms. Environment and Behavior, 30, 75-100, 1998.

- WILSON, E.O. Biophilia. Cambridge: Harvard University Press, 1984.

- WILSON, E.O. Diversidade da Vida. São Paulo: Companhia das Letras, 1994.

- WYSOR, M.S. Comparing College Students' Environmental Perceptions and Attitudes: A Methodological Investigation. Environment and Behavior, 15, 615-645, 1983. 
ANEXO 1 - Estatísticas descritivas - Estudo 3a e 3b;

ANEXO 2 - Boxplots, gráficos construídos com base na mediana, primeiro e terceiro quartis, e valores mínimo e máximo - Estudos 3a e 3b;

ANEXO 3 - Gráficos que representam a média mais ou menos duas vezes o erro padrão da média - Estudos 3a e 3b;

ANEXO 4 - Análises estatísticas referentes à diferenças de gênero (Estudos 3a e $3 b)$;

ANEXO 5 - Planilha com dados originais não tratados - Estudos 3 e 4 (em Microsoft Excel) - Não disponível na versão eletrônica desta tese, em formato PDF. 


\section{ANEXO 1 - ESTATÍSTICAS DESCRITIVAS - ESTUDO 3a e 3b}

\begin{tabular}{|c|c|c|c|c|c|c|c|c|c|}
\hline \multirow[b]{2}{*}{ Variável } & \multirow[b]{2}{*}{ Categoria } & \multicolumn{6}{|c|}{ Estatísticas Descritivas } & \multicolumn{2}{|c|}{ Normalidade } \\
\hline & & $n$ & Média & Mediana & $\begin{array}{l}\text { Desvio } \\
\text { Padrão }\end{array}$ & Mínimo & Máximo & $\begin{array}{l}\text { Kolmogorov- } \\
\text { Smirnov }\end{array}$ & $\begin{array}{l}\text { Shapiro- } \\
\text { Wilk }\end{array}$ \\
\hline \multirow[t]{8}{*}{ Auto-avaliação do conhecimento $\mathrm{A}$} & UFSCar, Controle, Pré & 33 & 59,06 & 62,00 & 16,38 & 24 & 86 & 0,198 & 0,249 \\
\hline & UFSCar, Controle, Pós & 31 & 58,03 & 61,00 & 21,24 & 22 & 95 & 0,200 & 0,132 \\
\hline & UFSCar, Experimento, Pré & 29 & 59,34 & 56,00 & 18,15 & 23 & 96 & 0,200 & 0,822 \\
\hline & UFSCar, Experimento, Pós & 31 & 69,03 & 67,00 & 15,62 & 42 & 95 & 0,200 & 0,292 \\
\hline & Magister, Controle, Pré & 29 & 59,07 & 62,00 & 16,05 & 24 & 81 & 0,200 & 0,077 \\
\hline & Magister, Controle, Pós & 27 & 55,67 & 58,00 & 20,59 & 22 & 88 & 0,200 & 0,098 \\
\hline & Magister, Experimento, Pré & 25 & 59,40 & 56,00 & 18,67 & 23 & 96 & 0,200 & 0,874 \\
\hline & Magister, Experimento, Pós & 28 & 69,86 & 71,00 & 16,09 & 42 & 95 & 0,200 & 0,246 \\
\hline \multirow[t]{8}{*}{ Auto-avaliação do conhecimento B } & UFSCar, Controle, Pré & 33 & 64,64 & 67,00 & 17,18 & 6 & 91 & 0,054 & 0,012 \\
\hline & UFSCar, Controle, Pós & 31 & 67,97 & 70,00 & 15,31 & 25 & 95 & 0,200 & 0,620 \\
\hline & UFSCar, Experimento, Pré & 29 & 63,52 & 65,00 & 17,22 & 36 & 96 & 0,200 & 0,213 \\
\hline & UFSCar, Experimento, Pós & 31 & 67,55 & 67,00 & 18,39 & 33 & 95 & 0,200 & 0,275 \\
\hline & Magister, Controle, Pré & 29 & 65,10 & 67,00 & 16,68 & 6 & 91 & 0,027 & 0,002 \\
\hline & Magister, Controle, Pós & 27 & 66,33 & 70,00 & 14,56 & 25 & 90 & 0,200 & 0,384 \\
\hline & Magister, Experimento, Pré & 25 & 61,84 & 62,00 & 16,85 & 36 & 96 & 0,200 & 0,383 \\
\hline & Magister, Experimento, Pós & 28 & 77,36 & 80,00 & 18,26 & 43 & 100 & 0,200 & 0,046 \\
\hline \multirow[t]{8}{*}{ Auto-avaliação do conhecimento $\mathrm{C}$} & UFSCar, Controle, Pré & 33 & 17,33 & 10,00 & 18,84 & 2 & 82 & 0,000 & 0,000 \\
\hline & UFSCar, Controle, Pós & 31 & 25,94 & 14,00 & 26,87 & 2 & 95 & 0,001 & 0,000 \\
\hline & UFSCar, Experimento, Pré & 29 & 19,55 & 15,00 & 15,20 & 2 & 54 & 0,081 & 0,006 \\
\hline & UFSCar, Experimento, Pós & 31 & 58,23 & 64,00 & 23,16 & 2 & 95 & 0,200 & 0,532 \\
\hline & Magister, Controle, Pré & 29 & 16,31 & 12,00 & 15,49 & 2 & 62 & 0,006 & 0,001 \\
\hline & Magister, Controle, Pós & 27 & 24,93 & 14,00 & 24,90 & 2 & 86 & 0,004 & 0,001 \\
\hline & Magister, Experimento, Pré & 25 & 20,12 & 17,00 & 14,23 & 2 & 54 & 0,173 & 0,046 \\
\hline & Magister, Experimento, Pós & 28 & 58,79 & 64,00 & 23,97 & 2 & 95 & 0,200 & 0,468 \\
\hline \multirow[t]{8}{*}{ Auto-avaliação do conhecimento $D$} & UFSCar, Controle, Pré & 33 & 47,61 & 50,00 & 18,88 & 4 & 82 & 0,200 & 0,954 \\
\hline & UFSCar, Controle, Pós & 31 & 53,94 & 56,00 & 20,60 & 18 & 95 & 0,200 & 0,633 \\
\hline & UFSCar, Experimento, Pré & 29 & 52,52 & 51,00 & 19,39 & 12 & 96 & 0,200 & 0,955 \\
\hline & UFSCar, Experimento, Pós & 31 & 61,68 & 60,00 & 20,33 & 2 & 95 & 0,200 & 0,375 \\
\hline & Magister, Controle, Pré & 29 & 46,14 & 46,00 & 18,97 & 4 & 82 & 0,200 & 0,983 \\
\hline & Magister, Controle, Pós & 27 & 50,37 & 55,00 & 18,56 & 18 & 80 & 0,200 & 0,194 \\
\hline & Magister, Experimento, Pré & 25 & 51,32 & 51,00 & 20,06 & 12 & 96 & 0,200 & 0,968 \\
\hline & Magister, Experimento, Pós & 28 & 61,82 & 62,50 & 21,35 & 2 & 95 & 0,200 & 0,356 \\
\hline \multirow[t]{8}{*}{ Auto-avaliação do conhecimento $\mathrm{E}$} & UFSCar, Controle, Pré & 33 & 59,15 & 67,00 & 19,68 & 15 & 88 & 0,003 & 0,011 \\
\hline & UFSCar, Controle, Pós & 31 & 61,10 & 66,00 & 21,11 & 20 & 95 & 0,174 & 0,118 \\
\hline & UFSCar, Experimento, Pré & 29 & 64,62 & 64,00 & 18,82 & 20 & 96 & 0,200 & 0,514 \\
\hline & UFSCar, Experimento, Pós & 31 & 71,68 & 72,00 & 16,23 & 33 & 97 & 0,200 & 0,455 \\
\hline & Magister, Controle, Pré & 29 & 58,59 & 67,00 & 19,82 & 15 & 82 & 0,002 & 0,003 \\
\hline & Magister, Controle, Pós & 27 & 58,70 & 64,00 & 20,68 & 20 & 89 & 0,200 & 0,073 \\
\hline & Magister, Experimento, Pré & 25 & 62,44 & 62,00 & 18,01 & 20 & 96 & 0,200 & 0,839 \\
\hline & Magister, Experimento, Pós & 28 & 72,46 & 74,50 & 16,53 & 33 & 97 & 0,200 & 0,386 \\
\hline
\end{tabular}




\begin{tabular}{|c|c|c|c|c|c|c|c|c|c|}
\hline \multirow[b]{2}{*}{ Variável } & \multirow[b]{2}{*}{ Categoria } & \multicolumn{6}{|c|}{ Estatísticas Descritivas } & \multicolumn{2}{|c|}{ Normalidade } \\
\hline & & $\mathrm{n}$ & Média & Mediana & $\begin{array}{l}\text { Desvio } \\
\text { Padrão }\end{array}$ & Mínimo & Máximo & $\begin{array}{l}\text { Kolmogorov- } \\
\text { Smirnov }\end{array}$ & $\begin{array}{l}\text { Shapiro- } \\
\text { Wilk }\end{array}$ \\
\hline \multirow[t]{8}{*}{ Auto-avaliação do conhecimento $F$} & UFSCar, Controle, Pré & 33 & 29,52 & 25,00 & 22,33 & 2 & 77 & 0,129 & 0,009 \\
\hline & UFSCar, Controle, Pós & 30 & 36,37 & 31,00 & 21,44 & 2 & 76 & 0,167 & 0,189 \\
\hline & UFSCar, Experimento, Pré & 29 & 33,00 & 27,00 & 24,59 & 2 & 95 & 0,071 & 0,052 \\
\hline & UFSCar, Experimento, Pós & 30 & 56,47 & 64,00 & 25,44 & 2 & 95 & 0,063 & 0,169 \\
\hline & Magister, Controle, Pré & 29 & 30,66 & 28,00 & 22,84 & 2 & 77 & 0,132 & 0,017 \\
\hline & Magister, Controle, Pós & 26 & 34,23 & 28,50 & 21,15 & 2 & 71 & 0,200 & 0,129 \\
\hline & Magister, Experimento, Pré & 25 & 35,08 & 34,00 & 23,56 & 2 & 95 & 0,147 & 0,204 \\
\hline & Magister, Experimento, Pós & 27 & 55,74 & 64,00 & 26,58 & 2 & 95 & 0,089 & 0,225 \\
\hline \multirow[t]{8}{*}{ Sentimentos A } & UFSCar, Controle, Pré & 33 & 48,45 & 51,00 & 32,51 & 4 & 95 & 0,017 & 0,001 \\
\hline & UFSCar, Controle, Pós & 31 & 30,81 & 31,00 & 24,49 & 1 & 79 & 0,042 & 0,012 \\
\hline & UFSCar, Experimento, Pré & 29 & 66,52 & 71,00 & 28,29 & 3 & 98 & 0,076 & 0,002 \\
\hline & UFSCar, Experimento, Pós & 31 & 29,87 & 15,00 & 29,88 & 2 & 95 & 0,000 & 0,000 \\
\hline & Magister, Controle, Pré & 29 & 41,41 & 41,00 & 24,24 & 11 & 89 & 0,043 & 0,027 \\
\hline & Magister, Controle, Pós & 27 & 49,04 & 51,00 & 31,24 & 4 & 95 & 0,036 & 0,006 \\
\hline & Magister, Experimento, Pré & 25 & 30,56 & 15,00 & 29,16 & 2 & 95 & 0,002 & 0,001 \\
\hline & Magister, Experimento, Pós & 28 & 66,18 & 73,00 & 28,87 & 3 & 98 & 0,042 & 0,003 \\
\hline \multirow[t]{8}{*}{ Sentimentos B } & UFSCar, Controle, Pré & 33 & 49,58 & 50,00 & 29,60 & 4 & 95 & 0,065 & 0,036 \\
\hline & UFSCar, Controle, Pós & 31 & 41,94 & 45,00 & 26,31 & 2 & 96 & 0,200 & 0,180 \\
\hline & UFSCar, Experimento, Pré & 29 & 49,66 & 50,00 & 26,00 & 4 & 98 & 0,080 & 0,082 \\
\hline & UFSCar, Experimento, Pós & 31 & 46,71 & 48,00 & 26,92 & 2 & 95 & 0,200 & 0,191 \\
\hline & Magister, Controle, Pré & 29 & 40,17 & 45,00 & 24,71 & 2 & 80 & 0,200 & 0,116 \\
\hline & Magister, Controle, Pós & 27 & 50,30 & 50,00 & 27,66 & 4 & 95 & 0,104 & 0,125 \\
\hline & Magister, Experimento, Pré & 25 & 47,12 & 49,00 & 26,95 & 4 & 95 & 0,200 & 0,324 \\
\hline & Magister, Experimento, Pós & 28 & 57,39 & 60,00 & 23,99 & 14 & 98 & 0,029 & 0,053 \\
\hline \multirow[t]{8}{*}{ Sentimentos C } & UFSCar, Controle, Pré & 33 & 47,88 & 48,00 & 26,48 & 3 & 95 & 0,163 & 0,067 \\
\hline & UFSCar, Controle, Pós & 31 & 45,55 & 50,00 & 30,35 & 2 & 96 & 0,048 & 0,006 \\
\hline & UFSCar, Experimento, Pré & 29 & 45,28 & 48,00 & 30,86 & 2 & 98 & 0,200 & 0,057 \\
\hline & UFSCar, Experimento, Pós & 31 & 34,68 & 42,00 & 22,57 & 2 & 77 & 0,042 & 0,045 \\
\hline & Magister, Controle, Pré & 29 & 43,07 & 47,00 & 29,47 & 2 & 80 & 0,067 & 0,002 \\
\hline & Magister, Controle, Pós & 27 & 48,59 & 48,00 & 22,85 & 3 & 80 & 0,200 & 0,143 \\
\hline & Magister, Experimento, Pré & 25 & 37,12 & 45,00 & 22,88 & 4 & 77 & 0,015 & 0,063 \\
\hline & Magister, Experimento, Pós & 28 & 43,64 & 47,00 & 30,30 & 2 & 98 & 0,200 & 0,081 \\
\hline \multirow[t]{8}{*}{ Sentimentos D } & UFSCar, Controle, Pré & 33 & 59,52 & 67,00 & 25,96 & 3 & 95 & 0,104 & 0,038 \\
\hline & UFSCar, Controle, Pós & 31 & 47,26 & 50,00 & 34,72 & 2 & 96 & 0,008 & 0,001 \\
\hline & UFSCar, Experimento, Pré & 29 & 71,93 & 78,00 & 22,95 & 6 & 98 & 0,025 & 0,002 \\
\hline & UFSCar, Experimento, Pós & 31 & 45,06 & 47,00 & 32,52 & 2 & 96 & 0,131 & 0,010 \\
\hline & Magister, Controle, Pré & 29 & 44,00 & 40,00 & 33,43 & 2 & 96 & 0,011 & 0,002 \\
\hline & Magister, Controle, Pós & 27 & 49,96 & 54,00 & 22,65 & 10 & 84 & 0,189 & 0,093 \\
\hline & Magister, Experimento, Pré & 25 & 42,60 & 47,00 & 30,42 & 4 & 96 & 0,200 & 0,044 \\
\hline & Magister, Experimento, Pós & 28 & 61,68 & 67,50 & 22,03 & 6 & 88 & 0,005 & 0,003 \\
\hline
\end{tabular}




\begin{tabular}{|c|c|c|c|c|c|c|c|c|c|}
\hline \multirow[b]{2}{*}{ Variável } & \multirow[b]{2}{*}{ Categoria } & \multicolumn{6}{|c|}{ Estatísticas Descritivas } & \multicolumn{2}{|c|}{ Normalidade } \\
\hline & & $\mathrm{n}$ & Média & Mediana & $\begin{array}{l}\text { Desvio } \\
\text { Padrão }\end{array}$ & Mínimo & Máximo & $\begin{array}{l}\text { Kolmogorov- } \\
\text { Smirnov }\end{array}$ & $\begin{array}{l}\text { Shapiro- } \\
\text { Wilk }\end{array}$ \\
\hline \multirow[t]{8}{*}{ Sentimentos $\mathrm{E}$} & UFSCar, Controle, Pré & 33 & 38,85 & 35,00 & 26,99 & 1 & 95 & 0,200 & 0,054 \\
\hline & UFSCar, Controle, Pós & 31 & 43,13 & 45,00 & 28,69 & 2 & 96 & 0,172 & 0,055 \\
\hline & UFSCar, Experimento, Pré & 29 & 44,48 & 47,00 & 28,91 & 2 & 98 & 0,200 & 0,110 \\
\hline & UFSCar, Experimento, Pós & 31 & 37,00 & 30,00 & 30,39 & 2 & 96 & 0,021 & 0,003 \\
\hline & Magister, Controle, Pré & 29 & 40,55 & 45,00 & 25,52 & 2 & 80 & 0,200 & 0,041 \\
\hline & Magister, Controle, Pós & 27 & 42,67 & 35,00 & 26,70 & 8 & 95 & 0,099 & 0,044 \\
\hline & Magister, Experimento, Pré & 25 & 34,36 & 30,00 & 27,37 & 3 & 95 & 0,058 & 0,011 \\
\hline & Magister, Experimento, Pós & 28 & 45,14 & 47,50 & 29,63 & 2 & 98 & 0,200 & 0,098 \\
\hline \multirow[t]{8}{*}{ Sentimentos $\mathrm{F}$} & UFSCar, Controle, Pré & 33 & 38,39 & 42,00 & 25,89 & 1 & 95 & 0,200 & 0,092 \\
\hline & UFSCar, Controle, Pós & 31 & 33,23 & 38,00 & 26,81 & 2 & 96 & 0,005 & 0,008 \\
\hline & UFSCar, Experimento, Pré & 29 & 38,28 & 43,00 & 23,27 & 2 & 88 & 0,200 & 0,253 \\
\hline & UFSCar, Experimento, Pós & 31 & 27,84 & 23,00 & 21,51 & 2 & 77 & 0,003 & 0,020 \\
\hline & Magister, Controle, Pré & 29 & 29,90 & 25,00 & 24,10 & 2 & 80 & 0,004 & 0,005 \\
\hline & Magister, Controle, Pós & 27 & 39,04 & 42,00 & 23,77 & 1 & 82 & 0,200 & 0,234 \\
\hline & Magister, Experimento, Pré & 25 & 26,76 & 23,00 & 19,88 & 2 & 70 & 0,004 & 0,034 \\
\hline & Magister, Experimento, Pós & 28 & 36,11 & 41,00 & 21,86 & 2 & 85 & 0,200 & 0,280 \\
\hline \multirow[t]{8}{*}{ Sentimentos $G$} & UFSCar, Controle, Pré & 33 & 29,97 & 20,00 & 23,79 & 1 & 94 & 0,000 & 0,001 \\
\hline & UFSCar, Controle, Pós & 31 & 24,19 & 19,00 & 24,25 & 1 & 85 & 0,000 & 0,000 \\
\hline & UFSCar, Experimento, Pré & 29 & 30,69 & 25,00 & 27,06 & 2 & 94 & 0,125 & 0,002 \\
\hline & UFSCar, Experimento, Pós & 31 & 20,10 & 18,00 & 17,35 & 2 & 71 & 0,009 & 0,002 \\
\hline & Magister, Controle, Pré & 29 & 23,62 & 19,00 & 23,10 & 1 & 85 & 0,000 & 0,000 \\
\hline & Magister, Controle, Pós & 27 & 34,07 & 21,00 & 24,23 & 1 & 94 & 0,000 & 0,013 \\
\hline & Magister, Experimento, Pré & 25 & 19,00 & 18,00 & 15,75 & 2 & 71 & 0,049 & 0,001 \\
\hline & Magister, Experimento, Pós & 28 & 29,25 & 23,00 & 25,35 & 2 & 94 & 0,161 & 0,004 \\
\hline \multirow[t]{8}{*}{ Sentimentos $\mathrm{H}$} & UFSCar, Controle, Pré & 33 & 42,12 & 45,00 & 29,23 & 1 & 95 & 0,105 & 0,038 \\
\hline & UFSCar, Controle, Pós & 31 & 36,74 & 30,00 & 29,01 & 2 & 96 & 0,041 & 0,012 \\
\hline & UFSCar, Experimento, Pré & 29 & 55,00 & 50,00 & 27,32 & 2 & 96 & 0,032 & 0,014 \\
\hline & UFSCar, Experimento, Pós & 31 & 36,10 & 36,00 & 25,84 & 3 & 95 & 0,033 & 0,050 \\
\hline & Magister, Controle, Pré & 29 & 34,72 & 22,00 & 29,24 & 2 & 96 & 0,006 & 0,005 \\
\hline & Magister, Controle, Pós & 27 & 40,78 & 45,00 & 26,06 & 1 & 80 & 0,200 & 0,064 \\
\hline & Magister, Experimento, Pré & 25 & 35,92 & 24,00 & 27,21 & 4 & 95 & 0,021 & 0,027 \\
\hline & Magister, Experimento, Pós & 28 & 53,71 & 50,00 & 27,52 & 2 & 96 & 0,179 & 0,030 \\
\hline \multirow[t]{8}{*}{ Sentimentos I } & UFSCar, Controle, Pré & 33 & 50,85 & 50,00 & 30,38 & 1 & 95 & 0,156 & 0,025 \\
\hline & UFSCar, Controle, Pós & 31 & 67,03 & 73,00 & 21,88 & 16 & 96 & 0,200 & 0,062 \\
\hline & UFSCar, Experimento, Pré & 29 & 57,34 & 60,00 & 24,96 & 3 & 96 & 0,015 & 0,104 \\
\hline & UFSCar, Experimento, Pós & 31 & 51,19 & 48,00 & 27,78 & 2 & 95 & 0,037 & 0,041 \\
\hline & Magister, Controle, Pré & 29 & 57,00 & 63,00 & 21,86 & 6 & 86 & 0,200 & 0,065 \\
\hline & Magister, Controle, Pós & 27 & 51,63 & 54,00 & 28,70 & 12 & 95 & 0,137 & 0,021 \\
\hline & Magister, Experimento, Pré & 25 & 42,40 & 40,00 & 27,05 & 2 & 85 & 0,146 & 0,033 \\
\hline & Magister, Experimento, Pós & 28 & 57,50 & 60,50 & 21,35 & 3 & 86 & 0,088 & 0,046 \\
\hline
\end{tabular}




\begin{tabular}{|c|c|c|c|c|c|c|c|c|c|}
\hline \multirow[b]{2}{*}{ Variável } & \multirow[b]{2}{*}{ Categoria } & \multicolumn{6}{|c|}{ Estatísticas Descritivas } & \multicolumn{2}{|c|}{ Normalidade } \\
\hline & & $\mathrm{n}$ & Média & Mediana & $\begin{array}{l}\text { Desvio } \\
\text { Padrão }\end{array}$ & Mínimo & Máximo & $\begin{array}{l}\text { Kolmogorov- } \\
\text { Smirnov }\end{array}$ & $\begin{array}{c}\text { Shapiro- } \\
\text { Wilk }\end{array}$ \\
\hline \multirow[t]{8}{*}{ Sentimentos $\mathrm{J}$} & UFSCar, Controle, Pré & 33 & 48,73 & 50,00 & 30,30 & 2 & 95 & 0,007 & 0,006 \\
\hline & UFSCar, Controle, Pós & 31 & 47,71 & 49,00 & 26,75 & 2 & 90 & 0,200 & 0,025 \\
\hline & UFSCar, Experimento, Pré & 29 & 48,59 & 49,00 & 26,44 & 3 & 98 & 0,197 & 0,313 \\
\hline & UFSCar, Experimento, Pós & 31 & 35,68 & 35,00 & 25,92 & 3 & 95 & 0,200 & 0,030 \\
\hline & Magister, Controle, Pré & 29 & 45,66 & 47,00 & 26,53 & 2 & 90 & 0,190 & 0,057 \\
\hline & Magister, Controle, Pós & 27 & 47,78 & 50,00 & 28,37 & 2 & 84 & 0,013 & 0,007 \\
\hline & Magister, Experimento, Pré & 25 & 37,32 & 35,00 & 27,45 & 3 & 95 & 0,200 & 0,056 \\
\hline & Magister, Experimento, Pós & 28 & 45,64 & 47,50 & 25,77 & 3 & 98 & 0,200 & 0,301 \\
\hline \multirow[t]{8}{*}{ Sentimentos K } & UFSCar, Controle, Pré & 33 & 45,85 & 47,00 & 28,96 & 2 & 95 & 0,200 & 0,077 \\
\hline & UFSCar, Controle, Pós & 31 & 35,00 & 24,00 & 26,89 & 2 & 83 & 0,001 & 0,003 \\
\hline & UFSCar, Experimento, Pré & 29 & 39,55 & 39,00 & 20,94 & 3 & 90 & 0,075 & 0,128 \\
\hline & UFSCar, Experimento, Pós & 31 & 33,94 & 42,00 & 23,97 & 2 & 81 & 0,043 & 0,022 \\
\hline & Magister, Controle, Pré & 29 & 37,83 & 26,00 & 26,62 & 2 & 83 & 0,010 & 0,013 \\
\hline & Magister, Controle, Pós & 27 & 43,19 & 45,00 & 27,52 & 2 & 82 & 0,178 & 0,026 \\
\hline & Magister, Experimento, Pré & 25 & 34,80 & 42,00 & 21,69 & 2 & 75 & 0,020 & 0,046 \\
\hline & Magister, Experimento, Pós & 28 & 38,36 & 36,00 & 20,64 & 3 & 84 & 0,200 & 0,177 \\
\hline \multirow[t]{8}{*}{ Atitudes Pró-Ambiente A } & UFSCar, Controle, Pré & 33 & 69,27 & 77,00 & 17,37 & 25 & 90 & 0,005 & 0,001 \\
\hline & UFSCar, Controle, Pós & 31 & 65,77 & 72,00 & 20,37 & 12 & 89 & 0,003 & 0,001 \\
\hline & UFSCar, Experimento, Pré & 29 & 55,83 & 64,00 & 23,48 & 3 & 86 & 0,079 & 0,046 \\
\hline & UFSCar, Experimento, Pós & 31 & 77,13 & 82,00 & 19,96 & 25 & 100 & 0,140 & 0,017 \\
\hline & Magister, Controle, Pré & 29 & 67,52 & 72,00 & 17,81 & 25 & 90 & 0,089 & 0,013 \\
\hline & Magister, Controle, Pós & 27 & 63,33 & 72,00 & 20,72 & 12 & 89 & 0,022 & 0,006 \\
\hline & Magister, Experimento, Pré & 25 & 55,28 & 64,00 & 23,45 & 3 & 86 & 0,078 & 0,041 \\
\hline & Magister, Experimento, Pós & 28 & 77,61 & 82,00 & 20,75 & 25 & 100 & 0,092 & 0,011 \\
\hline \multirow[t]{8}{*}{ Atitudes Pró-Ambiente B } & UFSCar, Controle, Pré & 33 & 56,55 & 61,00 & 20,06 & 12 & 87 & 0,013 & 0,066 \\
\hline & UFSCar, Controle, Pós & 31 & 54,90 & 55,00 & 20,74 & 5 & 89 & 0,200 & 0,243 \\
\hline & UFSCar, Experimento, Pré & 29 & 58,69 & 60,00 & 20,33 & 2 & 86 & 0,200 & 0,146 \\
\hline & UFSCar, Experimento, Pós & 31 & 67,58 & 72,00 & 21,53 & 10 & 100 & 0,200 & 0,033 \\
\hline & Magister, Controle, Pré & 29 & 56,10 & 61,00 & 20,18 & 12 & 87 & 0,035 & 0,099 \\
\hline & Magister, Controle, Pós & 27 & 53,63 & 55,00 & 20,65 & 5 & 89 & 0,200 & 0,421 \\
\hline & Magister, Experimento, Pré & 25 & 55,68 & 59,00 & 19,64 & 2 & 86 & 0,200 & 0,355 \\
\hline & Magister, Experimento, Pós & 28 & 67,75 & 73,00 & 22,56 & 10 & 100 & 0,200 & 0,037 \\
\hline \multirow[t]{8}{*}{ Atitudes Pró-Ambiente C } & UFSCar, Controle, Pré & 33 & 75,61 & 77,00 & 12,22 & 38 & 90 & 0,001 & 0,000 \\
\hline & UFSCar, Controle, Pós & 31 & 68,65 & 76,00 & 22,40 & 12 & 89 & 0,000 & 0,000 \\
\hline & UFSCar, Experimento, Pré & 29 & 73,24 & 79,00 & 15,98 & 20 & 86 & 0,000 & 0,000 \\
\hline & UFSCar, Experimento, Pós & 31 & 90,03 & 95,00 & 11,24 & 64 & 100 & 0,001 & 0,000 \\
\hline & Magister, Controle, Pré & 29 & 74,72 & 77,00 & 12,70 & 38 & 90 & 0,002 & 0,000 \\
\hline & Magister, Controle, Pós & 27 & 66,48 & 75,00 & 23,24 & 12 & 89 & 0,000 & 0,000 \\
\hline & Magister, Experimento, Pré & 25 & 71,44 & 77,00 & 16,54 & 20 & 86 & 0,000 & 0,000 \\
\hline & Magister, Experimento, Pós & 28 & 91,39 & 96,00 & 10,84 & 64 & 100 & 0,000 & 0,000 \\
\hline
\end{tabular}




\begin{tabular}{|c|c|c|c|c|c|c|c|c|c|}
\hline \multirow[b]{2}{*}{ Variável } & \multirow[b]{2}{*}{ Categoria } & \multicolumn{6}{|c|}{ Estatísticas Descritivas } & \multicolumn{2}{|c|}{ Normalidade } \\
\hline & & $\mathrm{n}$ & Média & Mediana & $\begin{array}{l}\text { Desvio } \\
\text { Padrão }\end{array}$ & Mínimo & Máximo & $\begin{array}{l}\text { Kolmogorov- } \\
\text { Smirnov }\end{array}$ & $\begin{array}{l}\text { Shapiro- } \\
\text { Wilk }\end{array}$ \\
\hline \multirow[t]{8}{*}{ Atitudes Pró-Ambiente D } & UFSCar, Controle, Pré & 33 & 40,58 & 36,00 & 27,21 & 1 & 82 & 0,200 & 0,032 \\
\hline & UFSCar, Controle, Pós & 31 & 45,61 & 46,00 & 26,52 & 1 & 89 & 0,200 & 0,123 \\
\hline & UFSCar, Experimento, Pré & 29 & 45,62 & 38,00 & 24,19 & 1 & 86 & 0,041 & 0,041 \\
\hline & UFSCar, Experimento, Pós & 31 & 60,48 & 60,00 & 25,93 & 13 & 100 & 0,200 & 0,214 \\
\hline & Magister, Controle, Pré & 29 & 40,07 & 35,00 & 27,02 & 1 & 82 & 0,200 & 0,047 \\
\hline & Magister, Controle, Pós & 27 & 45,78 & 46,00 & 24,09 & 5 & 89 & 0,200 & 0,279 \\
\hline & Magister, Experimento, Pré & 25 & 44,64 & 38,00 & 24,61 & 1 & 86 & 0,049 & 0,084 \\
\hline & Magister, Experimento, Pós & 28 & 61,36 & 61,00 & 27,16 & 13 & 100 & 0,146 & 0,097 \\
\hline \multirow[t]{8}{*}{ Atitudes Pró-Ambiente E } & UFSCar, Controle, Pré & 33 & 73,64 & 77,00 & 13,16 & 37 & 90 & 0,000 & 0,000 \\
\hline & UFSCar, Controle, Pós & 31 & 64,68 & 72,00 & 20,68 & 7 & 89 & 0,006 & 0,001 \\
\hline & UFSCar, Experimento, Pré & 29 & 66,38 & 70,00 & 15,81 & 40 & 86 & 0,200 & 0,012 \\
\hline & UFSCar, Experimento, Pós & 31 & 80,32 & 85,00 & 20,01 & 15 & 100 & 0,036 & 0,001 \\
\hline & Magister, Controle, Pré & 29 & 72,38 & 76,00 & 13,42 & 37 & 90 & 0,000 & 0,000 \\
\hline & Magister, Controle, Pós & 27 & 61,96 & 70,00 & 20,81 & 7 & 89 & 0,015 & 0,003 \\
\hline & Magister, Experimento, Pré & 25 & 64,72 & 68,00 & 15,39 & 40 & 86 & 0,200 & 0,064 \\
\hline & Magister, Experimento, Pós & 28 & 80,89 & 86,00 & 20,83 & 15 & 100 & 0,021 & 0,001 \\
\hline \multirow[t]{8}{*}{ Atitudes Pró-Ambiente F } & UFSCar, Controle, Pré & 33 & 70,45 & 77,00 & 18,87 & 2 & 90 & 0,000 & 0,000 \\
\hline & UFSCar, Controle, Pós & 31 & 68,35 & 75,00 & 20,16 & 10 & 89 & 0,000 & 0,000 \\
\hline & UFSCar, Experimento, Pré & 29 & 64,31 & 71,00 & 21,02 & 1 & 86 & 0,001 & 0,001 \\
\hline & UFSCar, Experimento, Pós & 31 & 80,23 & 87,00 & 20,48 & 15 & 100 & 0,027 & 0,001 \\
\hline & Magister, Controle, Pré & 29 & 70,28 & 76,00 & 18,99 & 2 & 90 & 0,001 & 0,000 \\
\hline & Magister, Controle, Pós & 27 & 66,19 & 75,00 & 20,74 & 10 & 89 & 0,000 & 0,000 \\
\hline & Magister, Experimento, Pré & 25 & 64,44 & 67,00 & 17,27 & 20 & 86 & 0,009 & 0,014 \\
\hline & Magister, Experimento, Pós & 28 & 80,64 & 87,00 & 21,37 & 15 & 100 & 0,018 & 0,001 \\
\hline \multirow[t]{8}{*}{ Atitudes Pró-Ambiente G } & UFSCar, Controle, Pré & 33 & 57,85 & 62,00 & 23,97 & 1 & 90 & 0,090 & 0,023 \\
\hline & UFSCar, Controle, Pós & 31 & 55,26 & 59,00 & 24,23 & 2 & 86 & 0,051 & 0,030 \\
\hline & UFSCar, Experimento, Pré & 29 & 47,38 & 40,00 & 25,94 & 1 & 86 & 0,046 & 0,056 \\
\hline & UFSCar, Experimento, Pós & 31 & 66,77 & 67,00 & 26,41 & 12 & 100 & 0,200 & 0,047 \\
\hline & Magister, Controle, Pré & 29 & 57,31 & 62,00 & 21,86 & 1 & 90 & 0,187 & 0,221 \\
\hline & Magister, Controle, Pós & 27 & 52,11 & 56,00 & 23,94 & 2 & 85 & 0,070 & 0,074 \\
\hline & Magister, Experimento, Pré & 25 & 46,44 & 40,00 & 24,66 & 1 & 86 & 0,085 & 0,237 \\
\hline & Magister, Experimento, Pós & 28 & 66,04 & 60,00 & 27,71 & 12 & 100 & 0,125 & 0,027 \\
\hline \multirow[t]{8}{*}{ Atitudes Pró-Ambiente H } & UFSCar, Controle, Pré & 33 & 66,94 & 70,00 & 13,92 & 35 & 85 & 0,091 & 0,015 \\
\hline & UFSCar, Controle, Pós & 31 & 58,03 & 64,00 & 21,34 & 5 & 89 & 0,046 & 0,112 \\
\hline & UFSCar, Experimento, Pré & 29 & 67,38 & 70,00 & 15,79 & 36 & 86 & 0,200 & 0,013 \\
\hline & UFSCar, Experimento, Pós & 31 & 75,87 & 79,00 & 20,00 & 12 & 100 & 0,200 & 0,009 \\
\hline & Magister, Controle, Pré & 29 & 66,34 & 68,00 & 13,08 & 35 & 85 & 0,100 & 0,059 \\
\hline & Magister, Controle, Pós & 27 & 56,89 & 64,00 & 21,15 & 5 & 89 & 0,122 & 0,139 \\
\hline & Magister, Experimento, Pré & 25 & 65,96 & 67,00 & 15,41 & 36 & 86 & 0,123 & 0,051 \\
\hline & Magister, Experimento, Pós & 28 & 76,46 & 81,00 & 20,87 & 12 & 100 & 0,200 & 0,007 \\
\hline
\end{tabular}




\begin{tabular}{|c|c|c|c|c|c|c|c|c|c|}
\hline \multirow[b]{2}{*}{ Variável } & \multirow[b]{2}{*}{ Categoria } & \multicolumn{6}{|c|}{ Estatísticas Descritivas } & \multicolumn{2}{|c|}{ Normalidade } \\
\hline & & $\mathrm{n}$ & Média & Mediana & $\begin{array}{l}\text { Desvio } \\
\text { Padrão }\end{array}$ & Mínimo & Máximo & $\begin{array}{l}\text { Kolmogorov- } \\
\text { Smirnov }\end{array}$ & $\begin{array}{l}\text { Shapiro- } \\
\text { Wilk }\end{array}$ \\
\hline \multirow[t]{8}{*}{ Atitudes Pró-Ambiente I } & UFSCar, Controle, Pré & 33 & 69,82 & 75,00 & 15,09 & 34 & 97 & 0,059 & 0,049 \\
\hline & UFSCar, Controle, Pós & 31 & 62,65 & 70,00 & 22,63 & 3 & 89 & 0,045 & 0,002 \\
\hline & UFSCar, Experimento, Pré & 29 & 60,90 & 65,00 & 18,37 & 25 & 86 & 0,080 & 0,055 \\
\hline & UFSCar, Experimento, Pós & 31 & 73,68 & 77,00 & 24,72 & 12 & 100 & 0,104 & 0,009 \\
\hline & Magister, Controle, Pré & 29 & 69,69 & 73,00 & 14,72 & 34 & 97 & 0,200 & 0,141 \\
\hline & Magister, Controle, Pós & 27 & 59,63 & 65,00 & 22,73 & 3 & 89 & 0,177 & 0,017 \\
\hline & Magister, Experimento, Pré & 25 & 58,68 & 65,00 & 18,28 & 25 & 86 & 0,048 & 0,086 \\
\hline & Magister, Experimento, Pós & 28 & 74,61 & 82,00 & 25,72 & 12 & 100 & 0,059 & 0,004 \\
\hline \multirow[t]{8}{*}{ Atitudes Pró-Ambiente J } & UFSCar, Controle, Pré & 33 & 61,85 & 65,00 & 18,64 & 25 & 96 & 0,176 & 0,086 \\
\hline & UFSCar, Controle, Pós & 31 & 67,84 & 75,00 & 18,83 & 11 & 89 & 0,000 & 0,000 \\
\hline & UFSCar, Experimento, Pré & 29 & 69,31 & 77,00 & 16,31 & 35 & 86 & 0,005 & 0,001 \\
\hline & UFSCar, Experimento, Pós & 31 & 84,45 & 95,00 & 21,43 & 12 & 100 & 0,000 & 0,000 \\
\hline & Magister, Controle, Pré & 29 & 61,55 & 68,00 & 18,66 & 25 & 96 & 0,064 & 0,072 \\
\hline & Magister, Controle, Pós & 27 & 65,63 & 72,00 & 19,20 & 11 & 89 & 0,000 & 0,001 \\
\hline & Magister, Experimento, Pré & 25 & 68,76 & 72,00 & 15,52 & 35 & 86 & 0,031 & 0,008 \\
\hline & Magister, Experimento, Pós & 28 & 85,50 & 95,50 & 22,17 & 12 & 100 & 0,000 & 0,000 \\
\hline \multirow[t]{8}{*}{ Atitudes Pró-Ambiente $\mathrm{K}$} & UFSCar, Controle, Pré & 33 & 58,61 & 70,00 & 28,18 & 2 & 90 & 0,011 & 0,001 \\
\hline & UFSCar, Controle, Pós & 31 & 58,39 & 72,00 & 25,51 & 1 & 89 & 0,001 & 0,003 \\
\hline & UFSCar, Experimento, Pré & 29 & 56,83 & 65,00 & 24,99 & 1 & 86 & 0,114 & 0,005 \\
\hline & UFSCar, Experimento, Pós & 31 & 71,29 & 76,00 & 26,77 & 8 & 100 & 0,090 & 0,004 \\
\hline & Magister, Controle, Pré & 29 & 56,00 & 68,00 & 28,90 & 2 & 90 & 0,019 & 0,003 \\
\hline & Magister, Controle, Pós & 27 & 56,33 & 68,00 & 25,55 & 1 & 89 & 0,003 & 0,007 \\
\hline & Magister, Experimento, Pré & 25 & 53,96 & 55,00 & 24,78 & 1 & 86 & 0,076 & 0,024 \\
\hline & Magister, Experimento, Pós & 28 & 71,89 & 76,50 & 27,87 & 8 & 100 & 0,041 & 0,003 \\
\hline \multirow[t]{8}{*}{ Atitudes Pró-Ambiente L } & UFSCar, Controle, Pré & 33 & 71,24 & 78,00 & 21,04 & 2 & 89 & 0,000 & 0,000 \\
\hline & UFSCar, Controle, Pós & 31 & 71,23 & 77,00 & 17,18 & 10 & 89 & 0,000 & 0,000 \\
\hline & UFSCar, Experimento, Pré & 29 & 61,62 & 65,00 & 21,50 & 8 & 86 & 0,016 & 0,012 \\
\hline & UFSCar, Experimento, Pós & 31 & 77,90 & 85,00 & 21,58 & 20 & 100 & 0,063 & 0,003 \\
\hline & Magister, Controle, Pré & 29 & 69,69 & 78,00 & 21,95 & 2 & 89 & 0,000 & 0,000 \\
\hline & Magister, Controle, Pós & 27 & 69,41 & 77,00 & 17,71 & 10 & 89 & 0,001 & 0,000 \\
\hline & Magister, Experimento, Pré & 25 & 59,92 & 62,00 & 21,34 & 8 & 86 & 0,098 & 0,073 \\
\hline & Magister, Experimento, Pós & 28 & 79,25 & 86,00 & 22,16 & 20 & 100 & 0,029 & 0,001 \\
\hline \multirow[t]{8}{*}{ Atitudes Pró-Ambiente M } & UFSCar, Controle, Pré & 33 & 72,82 & 75,00 & 15,21 & 12 & 90 & 0,020 & 0,000 \\
\hline & UFSCar, Controle, Pós & 31 & 67,94 & 75,00 & 20,24 & 12 & 89 & 0,000 & 0,000 \\
\hline & UFSCar, Experimento, Pré & 29 & 66,28 & 77,00 & 19,39 & 27 & 90 & 0,001 & 0,002 \\
\hline & UFSCar, Experimento, Pós & 31 & 86,90 & 92,00 & 14,95 & 56 & 100 & 0,002 & 0,000 \\
\hline & Magister, Controle, Pré & 29 & 74,17 & 75,00 & 11,02 & 52 & 90 & 0,200 & 0,209 \\
\hline & Magister, Controle, Pós & 27 & 65,59 & 74,00 & 20,68 & 12 & 89 & 0,001 & 0,000 \\
\hline & Magister, Experimento, Pré & 25 & 67,04 & 77,00 & 18,57 & 27 & 90 & 0,002 & 0,006 \\
\hline & Magister, Experimento, Pós & 28 & 88,50 & 96,00 & 14,38 & 57 & 100 & 0,001 & 0,000 \\
\hline
\end{tabular}




\begin{tabular}{|c|c|c|c|c|c|c|c|c|c|}
\hline \multirow[b]{2}{*}{ Variável } & \multirow[b]{2}{*}{ Categoria } & \multicolumn{6}{|c|}{ Estatísticas Descritivas } & \multicolumn{2}{|c|}{ Normalidade } \\
\hline & & $\mathrm{n}$ & Média & Mediana & $\begin{array}{l}\text { Desvio } \\
\text { Padrão }\end{array}$ & Mínimo & Máximo & $\begin{array}{l}\text { Kolmogorov- } \\
\text { Smirnov }\end{array}$ & $\begin{array}{l}\text { Shapiro- } \\
\text { Wilk }\end{array}$ \\
\hline \multirow[t]{8}{*}{ Atitudes Pró-Ambiente N } & UFSCar, Controle, Pré & 33 & 64,85 & 71,00 & 21,75 & 2 & 90 & 0,065 & 0,004 \\
\hline & UFSCar, Controle, Pós & 31 & 62,94 & 71,00 & 21,20 & 14 & 89 & 0,033 & 0,011 \\
\hline & UFSCar, Experimento, Pré & 29 & 49,59 & 44,00 & 27,23 & 1 & 86 & 0,189 & 0,055 \\
\hline & UFSCar, Experimento, Pós & 31 & 76,55 & 78,00 & 21,23 & 27 & 100 & 0,056 & 0,004 \\
\hline & Magister, Controle, Pré & 29 & 62,34 & 65,00 & 22,02 & 2 & 90 & 0,200 & 0,035 \\
\hline & Magister, Controle, Pós & 27 & 59,85 & 65,00 & 21,02 & 14 & 89 & 0,142 & 0,103 \\
\hline & Magister, Experimento, Pré & 25 & 49,20 & 44,00 & 25,60 & 1 & 86 & 0,200 & 0,210 \\
\hline & Magister, Experimento, Pós & 28 & 77,50 & 79,00 & 21,68 & 27 & 100 & 0,031 & 0,004 \\
\hline \multirow[t]{8}{*}{ Atitudes Pró-Ambiente O } & UFSCar, Controle, Pré & 33 & 67,03 & 73,00 & 22,55 & 1 & 90 & 0,002 & 0,000 \\
\hline & UFSCar, Controle, Pós & 31 & 62,94 & 70,00 & 22,68 & 2 & 89 & 0,024 & 0,003 \\
\hline & UFSCar, Experimento, Pré & 29 & 57,10 & 55,00 & 18,54 & 24 & 85 & 0,173 & 0,060 \\
\hline & UFSCar, Experimento, Pós & 31 & 78,61 & 84,00 & 19,42 & 14 & 100 & 0,018 & 0,002 \\
\hline & Magister, Controle, Pré & 29 & 64,83 & 71,00 & 23,19 & 1 & 90 & 0,002 & 0,000 \\
\hline & Magister, Controle, Pós & 27 & 59,81 & 68,00 & 22,69 & 2 & 89 & 0,076 & 0,025 \\
\hline & Magister, Experimento, Pré & 25 & 57,40 & 55,00 & 18,21 & 24 & 85 & 0,200 & 0,185 \\
\hline & Magister, Experimento, Pós & 28 & 79,46 & 84,50 & 19,82 & 14 & 100 & 0,011 & 0,001 \\
\hline \multirow[t]{8}{*}{ Atitudes Pró-Ambiente P } & UFSCar, Controle, Pré & 33 & 39,36 & 40,00 & 29,23 & 1 & 88 & 0,162 & 0,016 \\
\hline & UFSCar, Controle, Pós & 31 & 31,74 & 25,00 & 30,25 & 1 & 89 & 0,004 & 0,001 \\
\hline & UFSCar, Experimento, Pré & 29 & 34,03 & 37,00 & 23,72 & 1 & 85 & 0,043 & 0,010 \\
\hline & UFSCar, Experimento, Pós & 31 & 49,65 & 57,00 & 23,89 & 10 & 85 & 0,024 & 0,025 \\
\hline & Magister, Controle, Pré & 29 & 41,41 & 40,00 & 27,34 & 1 & 88 & 0,200 & 0,097 \\
\hline & Magister, Controle, Pós & 27 & 33,30 & 25,00 & 29,10 & 1 & 89 & 0,025 & 0,008 \\
\hline & Magister, Experimento, Pré & 25 & 33,04 & 37,00 & 22,37 & 1 & 83 & 0,113 & 0,039 \\
\hline & Magister, Experimento, Pós & 28 & 47,68 & 55,50 & 24,21 & 10 & 85 & 0,085 & 0,049 \\
\hline \multirow[t]{8}{*}{ Percepções A } & UFSCar, Controle, Pré & 33 & 18,64 & 7,00 & 25,04 & 1 & 77 & 0,000 & 0,000 \\
\hline & UFSCar, Controle, Pós & 31 & 20,55 & 10,00 & 21,21 & 1 & 68 & 0,000 & 0,000 \\
\hline & UFSCar, Experimento, Pré & 29 & 31,90 & 18,00 & 29,86 & 1 & 86 & 0,003 & 0,001 \\
\hline & UFSCar, Experimento, Pós & 31 & 44,58 & 40,00 & 25,34 & 10 & 99 & 0,200 & 0,075 \\
\hline & Magister, Controle, Pré & 29 & 30,59 & 18,00 & 26,05 & 11 & 87 & 0,000 & 0,000 \\
\hline & Magister, Controle, Pós & 27 & 32,30 & 22,00 & 21,06 & 11 & 78 & 0,005 & 0,003 \\
\hline & Magister, Experimento, Pré & 25 & 42,08 & 28,00 & 29,40 & 11 & 96 & 0,001 & 0,003 \\
\hline & Magister, Experimento, Pós & 28 & 52,68 & 49,00 & 24,48 & 20 & 100 & 0,200 & 0,052 \\
\hline \multirow[t]{8}{*}{ Percepções B } & UFSCar, Controle, Pré & 33 & 57,55 & 61,00 & 22,66 & 1 & 86 & 0,037 & 0,008 \\
\hline & UFSCar, Controle, Pós & 31 & 55,74 & 57,00 & 20,43 & 7 & 85 & 0,024 & 0,018 \\
\hline & UFSCar, Experimento, Pré & 29 & 53,34 & 57,00 & 22,51 & 11 & 86 & 0,200 & 0,140 \\
\hline & UFSCar, Experimento, Pós & 31 & 67,13 & 75,00 & 25,30 & 14 & 100 & 0,137 & 0,020 \\
\hline & Magister, Controle, Pré & 29 & 56,45 & 61,00 & 22,76 & 1 & 85 & 0,005 & 0,005 \\
\hline & Magister, Controle, Pós & 27 & 51,70 & 55,00 & 18,71 & 7 & 80 & 0,004 & 0,008 \\
\hline & Magister, Experimento, Pré & 25 & 53,80 & 57,00 & 21,15 & 12 & 86 & 0,200 & 0,322 \\
\hline & Magister, Experimento, Pós & 28 & 67,00 & 75,00 & 26,45 & 14 & 100 & 0,085 & 0,020 \\
\hline
\end{tabular}




\begin{tabular}{|c|c|c|c|c|c|c|c|c|c|}
\hline \multirow[b]{2}{*}{ Variável } & \multirow[b]{2}{*}{ Categoria } & \multicolumn{6}{|c|}{ Estatísticas Descritivas } & \multicolumn{2}{|c|}{ Normalidade } \\
\hline & & $\mathrm{n}$ & Média & Mediana & $\begin{array}{l}\text { Desvio } \\
\text { Padrão }\end{array}$ & Mínimo & Máximo & $\begin{array}{l}\text { Kolmogorov- } \\
\text { Smirnov }\end{array}$ & $\begin{array}{c}\text { Shapiro- } \\
\text { Wilk }\end{array}$ \\
\hline \multirow[t]{8}{*}{ Percepções C } & UFSCar, Controle, Pré & 33 & 61,21 & 67,00 & 24,79 & 1 & 87 & 0,009 & 0,001 \\
\hline & UFSCar, Controle, Pós & 31 & 62,58 & 71,00 & 24,54 & 5 & 86 & 0,008 & 0,000 \\
\hline & UFSCar, Experimento, Pré & 29 & 61,45 & 64,00 & 21,74 & 12 & 86 & 0,111 & 0,014 \\
\hline & UFSCar, Experimento, Pós & 31 & 86,45 & 89,00 & 13,81 & 57 & 100 & 0,035 & 0,001 \\
\hline & Magister, Controle, Pré & 29 & 60,28 & 67,00 & 25,34 & 1 & 86 & 0,016 & 0,001 \\
\hline & Magister, Controle, Pós & 27 & 59,48 & 65,00 & 24,84 & 5 & 84 & 0,005 & 0,001 \\
\hline & Magister, Experimento, Pré & 25 & 58,64 & 62,00 & 21,81 & 12 & 86 & 0,199 & 0,075 \\
\hline & Magister, Experimento, Pós & 28 & 88,04 & 91,00 & 13,44 & 57 & 100 & 0,014 & 0,000 \\
\hline \multirow[t]{8}{*}{ Percepções D } & UFSCar, Controle, Pré & 33 & 77,52 & 81,00 & 15,80 & 19 & 90 & 0,000 & 0,000 \\
\hline & UFSCar, Controle, Pós & 31 & 79,35 & 81,00 & 6,19 & 59 & 87 & 0,007 & 0,001 \\
\hline & UFSCar, Experimento, Pré & 29 & 75,07 & 80,00 & 13,34 & 34 & 86 & 0,001 & 0,000 \\
\hline & UFSCar, Experimento, Pós & 31 & 92,26 & 100,00 & 15,35 & 38 & 100 & 0,000 & 0,000 \\
\hline & Magister, Controle, Pré & 29 & 78,55 & 81,00 & 12,34 & 23 & 90 & 0,000 & 0,000 \\
\hline & Magister, Controle, Pós & 27 & 78,74 & 80,00 & 6,37 & 59 & 87 & 0,042 & 0,005 \\
\hline & Magister, Experimento, Pré & 25 & 75,48 & 78,00 & 11,33 & 34 & 86 & 0,009 & 0,000 \\
\hline & Magister, Experimento, Pós & 28 & 91,54 & 99,50 & 16,00 & 38 & 100 & 0,000 & 0,000 \\
\hline \multirow[t]{8}{*}{ Percepções E } & UFSCar, Controle, Pré & 33 & 80,09 & 81,00 & 8,48 & 40 & 90 & 0,000 & 0,000 \\
\hline & UFSCar, Controle, Pós & 31 & 77,10 & 80,00 & 12,99 & 11 & 86 & 0,000 & 0,000 \\
\hline & UFSCar, Experimento, Pré & 29 & 73,10 & 78,00 & 15,19 & 32 & 86 & 0,000 & 0,000 \\
\hline & UFSCar, Experimento, Pós & 31 & 89,97 & 98,00 & 15,92 & 44 & 100 & 0,000 & 0,000 \\
\hline & Magister, Controle, Pré & 29 & 79,66 & 80,00 & 8,64 & 40 & 90 & 0,000 & 0,000 \\
\hline & Magister, Controle, Pós & 27 & 76,15 & 78,00 & 13,67 & 11 & 85 & 0,000 & 0,000 \\
\hline & Magister, Experimento, Pré & 25 & 71,20 & 77,00 & 15,55 & 32 & 86 & 0,000 & 0,000 \\
\hline & Magister, Experimento, Pós & 28 & 89,68 & 98,00 & 16,64 & 44 & 100 & 0,000 & 0,000 \\
\hline \multirow[t]{8}{*}{ Percepções F } & UFSCar, Controle, Pré & 33 & 70,36 & 77,00 & 21,04 & 1 & 90 & 0,002 & 0,000 \\
\hline & UFSCar, Controle, Pós & 31 & 69,19 & 78,00 & 23,96 & 1 & 86 & 0,000 & 0,000 \\
\hline & UFSCar, Experimento, Pré & 29 & 60,76 & 75,00 & 28,02 & 1 & 86 & 0,000 & 0,000 \\
\hline & UFSCar, Experimento, Pós & 31 & 78,10 & 92,00 & 29,31 & 10 & 100 & 0,000 & 0,000 \\
\hline & Magister, Controle, Pré & 29 & 71,03 & 77,00 & 17,43 & 2 & 90 & 0,012 & 0,000 \\
\hline & Magister, Controle, Pós & 27 & 67,07 & 77,00 & 25,01 & 1 & 85 & 0,000 & 0,000 \\
\hline & Magister, Experimento, Pré & 25 & 62,04 & 75,00 & 26,43 & 1 & 86 & 0,000 & 0,000 \\
\hline & Magister, Experimento, Pós & 28 & 85,93 & 97,00 & 24,02 & 25 & 100 & 0,000 & 0,000 \\
\hline \multirow[t]{8}{*}{ Percepções G } & UFSCar, Controle, Pré & 33 & 44,91 & 38,00 & 25,68 & 1 & 87 & 0,000 & 0,003 \\
\hline & UFSCar, Controle, Pós & 31 & 47,61 & 44,00 & 29,57 & 1 & 85 & 0,036 & 0,007 \\
\hline & UFSCar, Experimento, Pré & 29 & 52,14 & 40,00 & 22,76 & 7 & 86 & 0,001 & 0,009 \\
\hline & UFSCar, Experimento, Pós & 31 & 84,48 & 94,00 & 19,59 & 32 & 100 & 0,000 & 0,000 \\
\hline & Magister, Controle, Pré & 29 & 47,07 & 42,00 & 24,88 & 6 & 92 & 0,000 & 0,005 \\
\hline & Magister, Controle, Pós & 27 & 50,56 & 42,00 & 30,03 & 6 & 90 & 0,129 & 0,012 \\
\hline & Magister, Experimento, Pré & 25 & 56,00 & 45,00 & 22,74 & 12 & 91 & 0,008 & 0,037 \\
\hline & Magister, Experimento, Pós & 28 & 87,68 & 95,00 & 16,71 & 36 & 100 & 0,000 & 0,000 \\
\hline
\end{tabular}




\begin{tabular}{|c|c|c|c|c|c|c|c|c|c|}
\hline \multirow[b]{2}{*}{ Variável } & \multirow[b]{2}{*}{ Categoria } & \multicolumn{6}{|c|}{ Estatísticas Descritivas } & \multicolumn{2}{|c|}{ Normalidade } \\
\hline & & $\mathrm{n}$ & Média & Mediana & $\begin{array}{l}\text { Desvio } \\
\text { Padrão }\end{array}$ & Mínimo & Máximo & $\begin{array}{l}\text { Kolmogorov- } \\
\text { Smirnov }\end{array}$ & $\begin{array}{l}\text { Shapiro- } \\
\text { Wilk }\end{array}$ \\
\hline \multirow[t]{8}{*}{ Percepções H } & UFSCar, Controle, Pré & 33 & 49,00 & 64,00 & 33,53 & 1 & 87 & 0,005 & 0,000 \\
\hline & UFSCar, Controle, Pós & 31 & 58,97 & 70,00 & 25,04 & 1 & 85 & 0,008 & 0,003 \\
\hline & UFSCar, Experimento, Pré & 29 & 66,31 & 75,00 & 21,24 & 6 & 86 & 0,021 & 0,001 \\
\hline & UFSCar, Experimento, Pós & 31 & 89,61 & 95,00 & 17,35 & 18 & 100 & 0,000 & 0,000 \\
\hline & Magister, Controle, Pré & 29 & 55,38 & 69,00 & 32,43 & 11 & 95 & 0,004 & 0,000 \\
\hline & Magister, Controle, Pós & 27 & 59,96 & 70,00 & 23,18 & 1 & 85 & 0,017 & 0,012 \\
\hline & Magister, Experimento, Pré & 25 & 63,32 & 70,00 & 21,42 & 6 & 86 & 0,066 & 0,007 \\
\hline & Magister, Experimento, Pós & 28 & 90,11 & 96,50 & 18,12 & 18 & 100 & 0,000 & 0,000 \\
\hline \multirow[t]{8}{*}{ Percepções I } & UFSCar, Controle, Pré & 33 & 77,88 & 80,00 & 10,57 & 34 & 87 & 0,003 & 0,000 \\
\hline & UFSCar, Controle, Pós & 31 & 78,45 & 80,00 & 6,09 & 62 & 87 & 0,001 & 0,038 \\
\hline & UFSCar, Experimento, Pré & 29 & 73,28 & 77,00 & 15,89 & 11 & 86 & 0,002 & 0,000 \\
\hline & UFSCar, Experimento, Pós & 31 & 94,29 & 98,00 & 8,84 & 57 & 100 & 0,000 & 0,000 \\
\hline & Magister, Controle, Pré & 29 & 77,17 & 80,00 & 10,80 & 34 & 87 & 0,002 & 0,000 \\
\hline & Magister, Controle, Pós & 27 & 77,74 & 80,00 & 6,16 & 62 & 87 & 0,008 & 0,155 \\
\hline & Magister, Experimento, Pré & 25 & 71,40 & 75,00 & 16,37 & 11 & 86 & 0,002 & 0,000 \\
\hline & Magister, Experimento, Pós & 28 & 95,14 & 99,00 & 8,78 & 57 & 100 & 0,000 & 0,000 \\
\hline \multirow[t]{8}{*}{ Percepções J } & UFSCar, Controle, Pré & 33 & 81,18 & 80,00 & 4,90 & 69 & 90 & 0,200 & 0,177 \\
\hline & UFSCar, Controle, Pós & 31 & 79,90 & 81,00 & 5,27 & 67 & 87 & 0,009 & 0,033 \\
\hline & UFSCar, Experimento, Pré & 29 & 75,69 & 80,00 & 12,08 & 27 & 86 & 0,006 & 0,000 \\
\hline & UFSCar, Experimento, Pós & 31 & 94,77 & 99,00 & 7,41 & 70 & 100 & 0,000 & 0,000 \\
\hline & Magister, Controle, Pré & 29 & 80,93 & 80,00 & 4,47 & 69 & 90 & 0,194 & 0,434 \\
\hline & Magister, Controle, Pós & 27 & 79,41 & 80,00 & 5,42 & 67 & 87 & 0,037 & 0,130 \\
\hline & Magister, Experimento, Pré & 25 & 74,20 & 77,00 & 12,39 & 27 & 86 & 0,059 & 0,000 \\
\hline & Magister, Experimento, Pós & 28 & 95,50 & 100,00 & 7,31 & 70 & 100 & 0,000 & 0,000 \\
\hline \multirow[t]{8}{*}{ Percepções K } & UFSCar, Controle, Pré & 33 & 75,42 & 80,00 & 13,93 & 33 & 90 & 0,000 & 0,000 \\
\hline & UFSCar, Controle, Pós & 31 & 70,35 & 75,00 & 19,31 & 5 & 87 & 0,000 & 0,000 \\
\hline & UFSCar, Experimento, Pré & 29 & 71,38 & 76,00 & 15,45 & 36 & 86 & 0,028 & 0,000 \\
\hline & UFSCar, Experimento, Pós & 31 & 90,00 & 97,00 & 15,58 & 55 & 100 & 0,000 & 0,000 \\
\hline & Magister, Controle, Pré & 29 & 76,03 & 80,00 & 13,03 & 33 & 90 & 0,000 & 0,000 \\
\hline & Magister, Controle, Pós & 27 & 68,44 & 75,00 & 20,00 & 5 & 87 & 0,000 & 0,000 \\
\hline & Magister, Experimento, Pré & 25 & 69,20 & 72,00 & 15,58 & 36 & 86 & 0,200 & 0,006 \\
\hline & Magister, Experimento, Pós & 28 & 93,21 & 99,50 & 12,39 & 55 & 100 & 0,000 & 0,000 \\
\hline \multirow[t]{8}{*}{ Percepções L } & UFSCar, Controle, Pré & 33 & 70,97 & 77,00 & 18,43 & 1 & 90 & 0,011 & 0,000 \\
\hline & UFSCar, Controle, Pós & 31 & 69,42 & 75,00 & 16,80 & 8 & 88 & 0,090 & 0,000 \\
\hline & UFSCar, Experimento, Pré & 29 & 64,79 & 66,00 & 17,29 & 35 & 86 & 0,200 & 0,020 \\
\hline & UFSCar, Experimento, Pós & 31 & 84,94 & 93,00 & 17,10 & 55 & 100 & 0,003 & 0,000 \\
\hline & Magister, Controle, Pré & 29 & 70,97 & 77,00 & 18,43 & 1 & 90 & 0,003 & 0,000 \\
\hline & Magister, Controle, Pós & 27 & 67,37 & 71,00 & 17,06 & 8 & 88 & 0,200 & 0,002 \\
\hline & Magister, Experimento, Pré & 25 & 61,88 & 62,00 & 16,81 & 35 & 86 & 0,200 & 0,145 \\
\hline & Magister, Experimento, Pós & 28 & 86,68 & 94,50 & 16,78 & 55 & 100 & 0,001 & 0,000 \\
\hline
\end{tabular}




\begin{tabular}{|c|c|c|c|c|c|c|c|c|c|}
\hline \multirow[b]{2}{*}{ Variável } & \multirow[b]{2}{*}{ Categoria } & \multicolumn{6}{|c|}{ Estatísticas Descritivas } & \multicolumn{2}{|c|}{ Normalidade } \\
\hline & & $\mathrm{n}$ & Média & Mediana & $\begin{array}{l}\text { Desvio } \\
\text { Padrão }\end{array}$ & Mínimo & Máximo & $\begin{array}{l}\text { Kolmogorov- } \\
\text { Smirnov }\end{array}$ & $\begin{array}{l}\text { Shapiro- } \\
\text { Wilk }\end{array}$ \\
\hline \multirow[t]{8}{*}{ Percepções M } & UFSCar, Controle, Pré & 33 & 43,15 & 40,00 & 27,49 & 1 & 82 & 0,200 & 0,018 \\
\hline & UFSCar, Controle, Pós & 31 & 43,48 & 44,00 & 25,38 & 1 & 85 & 0,200 & 0,139 \\
\hline & UFSCar, Experimento, Pré & 29 & 40,34 & 40,00 & 24,64 & 1 & 85 & 0,027 & 0,012 \\
\hline & UFSCar, Experimento, Pós & 31 & 53,35 & 60,00 & 22,88 & 10 & 100 & 0,005 & 0,027 \\
\hline & Magister, Controle, Pré & 29 & 56,07 & 52,00 & 26,79 & 11 & 92 & 0,112 & 0,030 \\
\hline & Magister, Controle, Pós & 27 & 52,15 & 54,00 & 24,81 & 11 & 95 & 0,200 & 0,252 \\
\hline & Magister, Experimento, Pré & 25 & 49,92 & 50,00 & 23,94 & 11 & 95 & 0,039 & 0,039 \\
\hline & Magister, Experimento, Pós & 28 & 62,04 & 69,50 & 22,75 & 20 & 100 & 0,028 & 0,084 \\
\hline \multirow[t]{8}{*}{ Afirmações Paradigmas A } & UFSCar, Controle, Pré & 33 & 2,97 & 3,00 & 1,02 & 1 & 5 & 0,006 & 0,014 \\
\hline & UFSCar, Controle, Pós & 31 & 2,87 & 3,00 & 1,02 & 1 & 5 & 0,000 & 0,003 \\
\hline & UFSCar, Experimento, Pré & 29 & 2,97 & 3,00 & 1,18 & 1 & 5 & 0,002 & 0,018 \\
\hline & UFSCar, Experimento, Pós & 31 & 2,94 & 3,00 & 0,77 & 1 & 4 & 0,000 & 0,000 \\
\hline & Magister, Controle, Pré & 29 & 3,03 & 3,00 & 0,98 & 1 & 5 & 0,003 & 0,017 \\
\hline & Magister, Controle, Pós & 27 & 2,93 & 3,00 & 1,07 & 1 & 5 & 0,000 & 0,011 \\
\hline & Magister, Experimento, Pré & 25 & 3,04 & 3,00 & 1,17 & 1 & 5 & 0,001 & 0,021 \\
\hline & Magister, Experimento, Pós & 28 & 2,89 & 3,00 & 0,79 & 1 & 4 & 0,000 & 0,001 \\
\hline \multirow[t]{8}{*}{ Afirmações Paradigmas C } & UFSCar, Controle, Pré & 33 & 4,61 & 5,00 & 0,79 & 2 & 5 & 0,000 & 0,000 \\
\hline & UFSCar, Controle, Pós & 31 & 4,45 & 5,00 & 0,81 & 2 & 5 & 0,000 & 0,000 \\
\hline & UFSCar, Experimento, Pré & 29 & 4,52 & 5,00 & 0,95 & 1 & 5 & 0,000 & 0,000 \\
\hline & UFSCar, Experimento, Pós & 31 & 4,32 & 5,00 & 0,94 & 1 & 5 & 0,000 & 0,000 \\
\hline & Magister, Controle, Pré & 29 & 4,59 & 5,00 & 0,82 & 2 & 5 & 0,000 & 0,000 \\
\hline & Magister, Controle, Pós & 27 & 4,41 & 5,00 & 0,84 & 2 & 5 & 0,000 & 0,000 \\
\hline & Magister, Experimento, Pré & 25 & 4,56 & 5,00 & 0,96 & 1 & 5 & 0,000 & 0,000 \\
\hline & Magister, Experimento, Pós & 28 & 4,32 & 5,00 & 0,98 & 1 & 5 & 0,000 & 0,000 \\
\hline \multirow[t]{8}{*}{ Afirmações Paradigmas E } & UFSCar, Controle, Pré & 33 & 4,64 & 5,00 & 0,60 & 3 & 5 & 0,000 & 0,000 \\
\hline & UFSCar, Controle, Pós & 31 & 4,61 & 5,00 & 0,50 & 4 & 5 & 0,000 & 0,000 \\
\hline & UFSCar, Experimento, Pré & 29 & 4,31 & 5,00 & 1,00 & 1 & 5 & 0,000 & 0,000 \\
\hline & UFSCar, Experimento, Pós & 31 & 4,42 & 5,00 & 0,67 & 3 & 5 & 0,000 & 0,000 \\
\hline & Magister, Controle, Pré & 29 & 4,66 & 5,00 & 0,61 & 3 & 5 & 0,000 & 0,000 \\
\hline & Magister, Controle, Pós & 27 & 4,59 & 5,00 & 0,50 & 4 & 5 & 0,000 & 0,000 \\
\hline & Magister, Experimento, Pré & 25 & 4,36 & 5,00 & 1,04 & 1 & 5 & 0,000 & 0,000 \\
\hline & Magister, Experimento, Pós & 28 & 4,43 & 5,00 & 0,69 & 3 & 5 & 0,000 & 0,000 \\
\hline \multirow[t]{8}{*}{ Afirmações Paradigmas G } & UFSCar, Controle, Pré & 33 & 2,85 & 3,00 & 1,28 & 1 & 5 & 0,002 & 0,008 \\
\hline & UFSCar, Controle, Pós & 31 & 2,97 & 3,00 & 1,20 & 1 & 5 & 0,040 & 0,023 \\
\hline & UFSCar, Experimento, Pré & 29 & 2,83 & 3,00 & 1,23 & 1 & 5 & 0,021 & 0,023 \\
\hline & UFSCar, Experimento, Pós & 31 & 2,61 & 2,00 & 1,02 & 1 & 4 & 0,000 & 0,001 \\
\hline & Magister, Controle, Pré & 29 & 2,86 & 3,00 & 1,25 & 1 & 5 & 0,003 & 0,017 \\
\hline & Magister, Controle, Pós & 27 & 3,04 & 3,00 & 1,13 & 1 & 5 & 0,025 & 0,045 \\
\hline & Magister, Experimento, Pré & 25 & 2,80 & 3,00 & 1,22 & 1 & 5 & 0,015 & 0,031 \\
\hline & Magister, Experimento, Pós & 28 & 2,71 & 3,00 & 1,01 & 1 & 4 & 0,001 & 0,002 \\
\hline
\end{tabular}




\begin{tabular}{|c|c|c|c|c|c|c|c|c|c|}
\hline \multirow[b]{2}{*}{ Variável } & \multirow[b]{2}{*}{ Categoria } & \multicolumn{6}{|c|}{ Estatísticas Descritivas } & \multicolumn{2}{|c|}{ Normalidade } \\
\hline & & $\mathrm{n}$ & Média & Mediana & $\begin{array}{l}\text { Desvio } \\
\text { Padrão }\end{array}$ & Mínimo & Máximo & $\begin{array}{l}\text { Kolmogorov- } \\
\text { Smirnov }\end{array}$ & $\begin{array}{l}\text { Shapiro- } \\
\text { Wilk }\end{array}$ \\
\hline \multirow[t]{8}{*}{ Afirmações Paradigmas I } & UFSCar, Controle, Pré & 33 & 4,55 & 5,00 & 0,87 & 2 & 5 & 0,000 & 0,000 \\
\hline & UFSCar, Controle, Pós & 31 & 4,42 & 5,00 & 0,89 & 2 & 5 & 0,000 & 0,000 \\
\hline & UFSCar, Experimento, Pré & 29 & 4,62 & 5,00 & 0,78 & 2 & 5 & 0,000 & 0,000 \\
\hline & UFSCar, Experimento, Pós & 31 & 4,35 & 5,00 & 0,80 & 2 & 5 & 0,000 & 0,000 \\
\hline & Magister, Controle, Pré & 29 & 4,69 & 5,00 & 0,71 & 2 & 5 & 0,000 & 0,000 \\
\hline & Magister, Controle, Pós & 27 & 4,48 & 5,00 & 0,80 & 2 & 5 & 0,000 & 0,000 \\
\hline & Magister, Experimento, Pré & 25 & 4,72 & 5,00 & 0,74 & 2 & 5 & 0,000 & 0,000 \\
\hline & Magister, Experimento, Pós & 28 & 4,46 & 5,00 & 0,69 & 3 & 5 & 0,000 & 0,000 \\
\hline \multirow[t]{8}{*}{ Afirmações Paradigmas K } & UFSCar, Controle, Pré & 33 & 3,91 & 4,00 & 1,21 & 1 & 5 & 0,000 & 0,000 \\
\hline & UFSCar, Controle, Pós & 31 & 3,74 & 4,00 & 1,12 & 1 & 5 & 0,002 & 0,001 \\
\hline & UFSCar, Experimento, Pré & 29 & 3,52 & 4,00 & 0,99 & 2 & 5 & 0,003 & 0,004 \\
\hline & UFSCar, Experimento, Pós & 31 & 3,61 & 4,00 & 0,99 & 2 & 5 & 0,001 & 0,002 \\
\hline & Magister, Controle, Pré & 29 & 3,86 & 4,00 & 1,25 & 1 & 5 & 0,000 & 0,000 \\
\hline & Magister, Controle, Pós & 27 & 3,89 & 4,00 & 1,05 & 1 & 5 & 0,004 & 0,002 \\
\hline & Magister, Experimento, Pré & 25 & 3,64 & 4,00 & 0,95 & 2 & 5 & 0,007 & 0,009 \\
\hline & Magister, Experimento, Pós & 28 & 3,61 & 3,50 & 1,03 & 2 & 5 & 0,001 & 0,003 \\
\hline \multirow[t]{8}{*}{ Afirmações Paradigmas L } & UFSCar, Controle, Pré & 33 & 4,55 & 5,00 & 0,71 & 3 & 5 & 0,000 & 0,000 \\
\hline & UFSCar, Controle, Pós & 31 & 4,45 & 5,00 & 0,81 & 2 & 5 & 0,000 & 0,000 \\
\hline & UFSCar, Experimento, Pré & 29 & 4,31 & 5,00 & 0,97 & 2 & 5 & 0,000 & 0,000 \\
\hline & UFSCar, Experimento, Pós & 31 & 4,35 & 4,00 & 0,61 & 3 & 5 & 0,000 & 0,000 \\
\hline & Magister, Controle, Pré & 29 & 4,55 & 5,00 & 0,74 & 3 & 5 & 0,000 & 0,000 \\
\hline & Magister, Controle, Pós & 27 & 4,41 & 5,00 & 0,84 & 2 & 5 & 0,000 & 0,000 \\
\hline & Magister, Experimento, Pré & 25 & 4,52 & 5,00 & 0,82 & 2 & 5 & 0,000 & 0,000 \\
\hline & Magister, Experimento, Pós & 28 & 4,39 & 4,00 & 0,63 & 3 & 5 & 0,000 & 0,000 \\
\hline \multirow[t]{8}{*}{ Afirmações Paradigmas O } & UFSCar, Controle, Pré & 33 & 3,73 & 4,00 & 1,28 & 1 & 5 & 0,000 & 0,000 \\
\hline & UFSCar, Controle, Pós & 31 & 3,84 & 4,00 & 1,00 & 2 & 5 & 0,003 & 0,001 \\
\hline & UFSCar, Experimento, Pré & 29 & 3,72 & 4,00 & 1,10 & 2 & 5 & 0,000 & 0,000 \\
\hline & UFSCar, Experimento, Pós & 31 & 3,55 & 4,00 & 1,09 & 1 & 5 & 0,001 & 0,004 \\
\hline & Magister, Controle, Pré & 29 & 3,79 & 4,00 & 1,18 & 1 & 5 & 0,000 & 0,001 \\
\hline & Magister, Controle, Pós & 27 & 3,81 & 4,00 & 1,04 & 2 & 5 & 0,005 & 0,002 \\
\hline & Magister, Experimento, Pré & 25 & 3,84 & 4,00 & 1,11 & 2 & 5 & 0,000 & 0,001 \\
\hline & Magister, Experimento, Pós & 28 & 3,54 & 4,00 & 1,14 & 1 & 5 & 0,008 & 0,007 \\
\hline \multirow[t]{8}{*}{ Afirmações Paradigmas P } & UFSCar, Controle, Pré & 33 & 4,82 & 5,00 & 0,46 & 3 & 5 & 0,000 & 0,000 \\
\hline & UFSCar, Controle, Pós & 31 & 4,61 & 5,00 & 0,62 & 3 & 5 & 0,000 & 0,000 \\
\hline & UFSCar, Experimento, Pré & 29 & 4,34 & 5,00 & 1,01 & 2 & 5 & 0,000 & 0,000 \\
\hline & UFSCar, Experimento, Pós & 31 & 3,94 & 4,00 & 1,03 & 2 & 5 & 0,000 & 0,000 \\
\hline & Magister, Controle, Pré & 29 & 4,83 & 5,00 & 0,47 & 3 & 5 & 0,000 & 0,000 \\
\hline & Magister, Controle, Pós & 27 & 4,63 & 5,00 & 0,56 & 3 & 5 & 0,000 & 0,000 \\
\hline & Magister, Experimento, Pré & 25 & 4,32 & 5,00 & 1,03 & 2 & 5 & 0,000 & 0,000 \\
\hline & Magister, Experimento, Pós & 28 & 3,96 & 4,00 & 1,00 & 2 & 5 & 0,000 & 0,000 \\
\hline
\end{tabular}




\begin{tabular}{|c|c|c|c|c|c|c|c|c|c|}
\hline \multirow[b]{2}{*}{ Variável } & \multirow[b]{2}{*}{ Categoria } & \multicolumn{6}{|c|}{ Estatísticas Descritivas } & \multicolumn{2}{|c|}{ Normalidade } \\
\hline & & $\mathrm{n}$ & Média & Mediana & $\begin{array}{l}\text { Desvio } \\
\text { Padrão }\end{array}$ & Mínimo & Máximo & $\begin{array}{l}\text { Kolmogorov- } \\
\text { Smirnov }\end{array}$ & $\begin{array}{l}\text { Shapiro- } \\
\text { Wilk }\end{array}$ \\
\hline \multirow[t]{8}{*}{ Afirmações Paradigmas B } & UFSCar, Controle, Pré & 33 & 3,76 & 4,00 & 1,20 & 1 & 5 & 0,001 & 0,001 \\
\hline & UFSCar, Controle, Pós & 31 & 3,35 & 3,00 & 1,14 & 1 & 5 & 0,022 & 0,010 \\
\hline & UFSCar, Experimento, Pré & 29 & 3,76 & 4,00 & 1,18 & 1 & 5 & 0,004 & 0,002 \\
\hline & UFSCar, Experimento, Pós & 31 & 3,68 & 4,00 & 1,25 & 1 & 5 & 0,001 & 0,001 \\
\hline & Magister, Controle, Pré & 29 & 3,79 & 4,00 & 1,21 & 1 & 5 & 0,001 & 0,001 \\
\hline & Magister, Controle, Pós & 27 & 3,41 & 3,00 & 1,19 & 1 & 5 & 0,037 & 0,016 \\
\hline & Magister, Experimento, Pré & 25 & 3,72 & 4,00 & 1,24 & 1 & 5 & 0,006 & 0,003 \\
\hline & Magister, Experimento, Pós & 28 & 3,68 & 4,00 & 1,25 & 1 & 5 & 0,003 & 0,002 \\
\hline \multirow[t]{8}{*}{ Afirmações Paradigmas D } & UFSCar, Controle, Pré & 33 & 3,61 & 4,00 & 1,06 & 1 & 5 & 0,000 & 0,001 \\
\hline & UFSCar, Controle, Pós & 31 & 3,74 & 4,00 & 0,77 & 2 & 5 & 0,000 & 0,000 \\
\hline & UFSCar, Experimento, Pré & 29 & 3,79 & 4,00 & 0,94 & 2 & 5 & 0,000 & 0,002 \\
\hline & UFSCar, Experimento, Pós & 31 & 3,77 & 4,00 & 0,92 & 2 & 5 & 0,000 & 0,002 \\
\hline & Magister, Controle, Pré & 29 & 3,55 & 4,00 & 1,06 & 1 & 5 & 0,000 & 0,001 \\
\hline & Magister, Controle, Pós & 27 & 3,74 & 4,00 & 0,76 & 2 & 5 & 0,000 & 0,000 \\
\hline & Magister, Experimento, Pré & 25 & 3,72 & 4,00 & 0,98 & 2 & 5 & 0,005 & 0,007 \\
\hline & Magister, Experimento, Pós & 28 & 3,71 & 4,00 & 0,94 & 2 & 5 & 0,001 & 0,004 \\
\hline \multirow[t]{8}{*}{ Afirmações Paradigmas F } & UFSCar, Controle, Pré & 33 & 2,64 & 3,00 & 1,27 & 1 & 5 & 0,001 & 0,001 \\
\hline & UFSCar, Controle, Pós & 31 & 2,97 & 3,00 & 1,28 & 1 & 5 & 0,055 & 0,017 \\
\hline & UFSCar, Experimento, Pré & 29 & 3,00 & 3,00 & 1,20 & 1 & 5 & 0,009 & 0,026 \\
\hline & UFSCar, Experimento, Pós & 31 & 3,16 & 3,00 & 0,73 & 2 & 4 & 0,000 & 0,000 \\
\hline & Magister, Controle, Pré & 29 & 2,66 & 3,00 & 1,20 & 1 & 5 & 0,001 & 0,005 \\
\hline & Magister, Controle, Pós & 27 & 3,04 & 3,00 & 1,29 & 1 & 5 & 0,094 & 0,031 \\
\hline & Magister, Experimento, Pré & 25 & 3,00 & 3,00 & 1,22 & 1 & 5 & 0,003 & 0,024 \\
\hline & Magister, Experimento, Pós & 28 & 3,07 & 3,00 & 0,72 & 2 & 4 & 0,000 & 0,000 \\
\hline \multirow[t]{8}{*}{ Afirmações Paradigmas H } & UFSCar, Controle, Pré & 33 & 4,15 & 5,00 & 1,09 & 1 & 5 & 0,000 & 0,000 \\
\hline & UFSCar, Controle, Pós & 31 & 4,16 & 4,00 & 0,97 & 2 & 5 & 0,000 & 0,000 \\
\hline & UFSCar, Experimento, Pré & 29 & 4,07 & 4,00 & 0,96 & 2 & 5 & 0,000 & 0,000 \\
\hline & UFSCar, Experimento, Pós & 31 & 4,06 & 4,00 & 1,09 & 1 & 5 & 0,000 & 0,000 \\
\hline & Magister, Controle, Pré & 29 & 4,10 & 5,00 & 1,14 & 1 & 5 & 0,000 & 0,000 \\
\hline & Magister, Controle, Pós & 27 & 4,07 & 4,00 & 1,00 & 2 & 5 & 0,000 & 0,000 \\
\hline & Magister, Experimento, Pré & 25 & 4,12 & 4,00 & 0,93 & 2 & 5 & 0,000 & 0,000 \\
\hline & Magister, Experimento, Pós & 28 & 4,11 & 4,00 & 1,07 & 1 & 5 & 0,000 & 0,000 \\
\hline \multirow[t]{8}{*}{ Afirmações Paradigmas J } & UFSCar, Controle, Pré & 33 & 3,94 & 4,00 & 1,12 & 1 & 5 & 0,000 & 0,000 \\
\hline & UFSCar, Controle, Pós & 31 & 3,94 & 4,00 & 0,96 & 2 & 5 & 0,000 & 0,001 \\
\hline & UFSCar, Experimento, Pré & 29 & 4,21 & 5,00 & 1,01 & 1 & 5 & 0,000 & 0,000 \\
\hline & UFSCar, Experimento, Pós & 31 & 3,84 & 4,00 & 0,90 & 2 & 5 & 0,001 & 0,001 \\
\hline & Magister, Controle, Pré & 29 & 3,86 & 4,00 & 1,13 & 1 & 5 & 0,001 & 0,001 \\
\hline & Magister, Controle, Pós & 27 & 4,04 & 4,00 & 0,90 & 2 & 5 & 0,000 & 0,001 \\
\hline & Magister, Experimento, Pré & 25 & 4,24 & 5,00 & 1,05 & 1 & 5 & 0,000 & 0,000 \\
\hline & Magister, Experimento, Pós & 28 & 3,82 & 4,00 & 0,90 & 2 & 5 & 0,001 & 0,003 \\
\hline
\end{tabular}


Generated by Foxit PDF Creator (C) Foxit Software

http://www.foxitsoftware.com For evaluation only.

\begin{tabular}{|c|c|c|c|c|c|c|c|c|c|c|}
\hline \multicolumn{9}{|c|}{ Estatísticas Descritivas } & \multicolumn{2}{|c|}{ Normalidade } \\
\hline Variável & \multirow{2}{*}{$\begin{array}{l}\text { Categoria } \\
\text { UFSCar, Controle, Pré }\end{array}$} & \multirow{2}{*}{ Média } & \multirow{2}{*}{$\begin{array}{c}\text { Mediana } \\
33\end{array}$} & \multicolumn{2}{|c|}{$\begin{array}{l}\text { Desvio M } \\
\text { Padrão }\end{array}$} & Mínimo & \multicolumn{2}{|c|}{ Máximo } & \multirow{2}{*}{$\begin{array}{c}\begin{array}{c}\text { Kolmogorov- } \\
\text { Smirnov }\end{array} \\
0,008\end{array}$} & \multirow{2}{*}{$\begin{array}{c}\begin{array}{c}\text { Shapiro- } \\
\text { Wilk }\end{array} \\
0,005\end{array}$} \\
\hline Afirmações Paradigmas M & & & & 3,24 & 3,00 & 1,30 & 1 & 5 & & \\
\hline & UFSCar, Controle, Pós & & 31 & 3,42 & 4,00 & 1,15 & 1 & 5 & 0,000 & 0,001 \\
\hline & UFSCar, Experimento, Pré & & 29 & 3,41 & 3,00 & 1,09 & 2 & 5 & 0,004 & 0,002 \\
\hline & UFSCar, Experimento, Pós & & 31 & 3,19 & 3,00 & 1,11 & 1 & 5 & 0,000 & 0,006 \\
\hline & Magister, Controle, Pré & & 29 & 3,31 & 3,00 & 1,26 & 1 & 5 & 0,014 & 0,010 \\
\hline & Magister, Controle, Pós & & 27 & 3,52 & 4,00 & 1,09 & 1 & 5 & 0,000 & 0,000 \\
\hline & Magister, Experimento, Pré & & 25 & 3,60 & 4,00 & 1,04 & 2 & 5 & 0,013 & 0,006 \\
\hline & Magister, Experimento, Pós & & 28 & 3,18 & 3,00 & 1,02 & 1 & 5 & 0,000 & 0,006 \\
\hline \multirow[t]{8}{*}{ Afirmações Paradigmas N } & UFSCar, Controle, Pré & & 33 & 4,82 & 5,00 & 0,39 & 4 & 5 & 0,000 & 0,000 \\
\hline & UFSCar, Controle, Pós & & 31 & 4,52 & 5,00 & 0,85 & 1 & 5 & 0,000 & 0,000 \\
\hline & UFSCar, Experimento, Pré & & 29 & 4,55 & 5,00 & 0,87 & 1 & 5 & 0,000 & 0,000 \\
\hline & UFSCar, Experimento, Pós & & 31 & 4,52 & 5,00 & 0,57 & 3 & 5 & 0,000 & 0,000 \\
\hline & Magister, Controle, Pré & & 29 & 4,83 & 5,00 & 0,38 & 4 & 5 & 0,000 & 0,000 \\
\hline & Magister, Controle, Pós & & 27 & 4,44 & 5,00 & 0,89 & 1 & 5 & 0,000 & 0,000 \\
\hline & Magister, Experimento, Pré & & 25 & 4,60 & 5,00 & 0,87 & 1 & 5 & 0,000 & 0,000 \\
\hline & Magister, Experimento, Pós & & 28 & 4,50 & 5,00 & 0,58 & 3 & 5 & 0,000 & 0,000 \\
\hline
\end{tabular}


ANEXO 2 - BOXPLOTS, GRÁFICOS CONSTRUÍDOS COM BASE NA MEDIANA, PRIMEIRO E TERCEIRO QUARTIS, E VALORES MÍNIMO E MÁXIMO - ESTUDOS 3a E 3b Boxplots 2A - Auto-avaliação do conhecimento sobre Mata Atlântica (A)

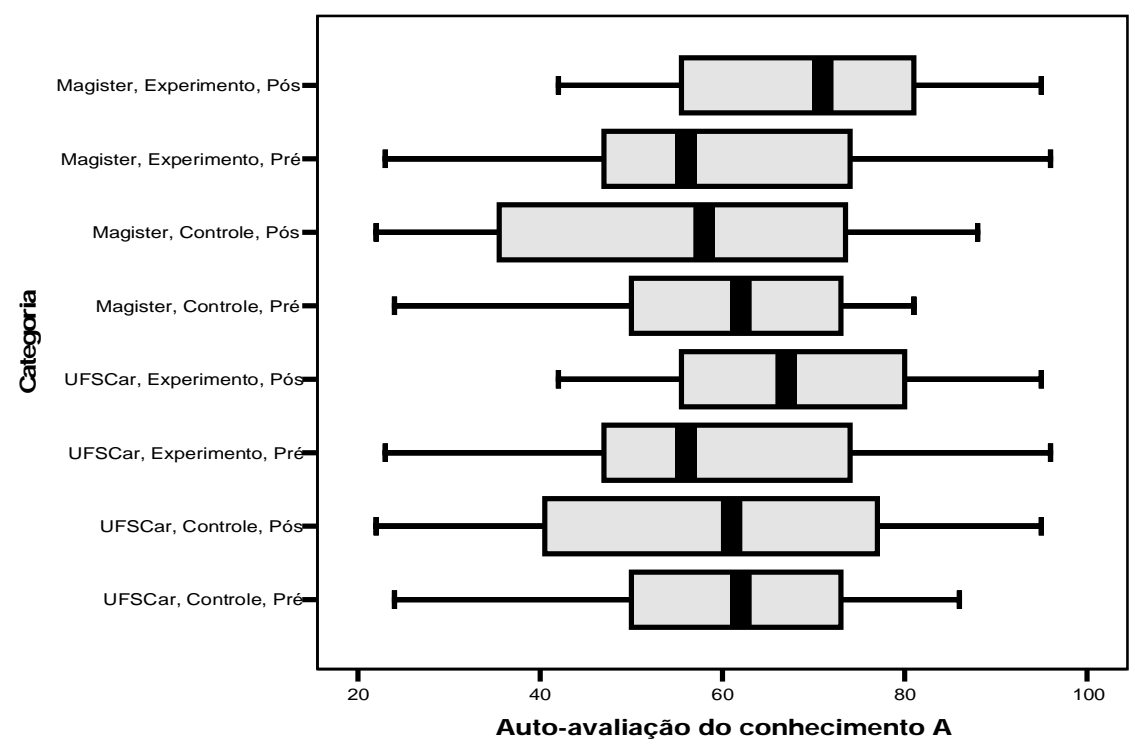

2B - Auto-avaliação do conhecimento Meio Ambiente (B)

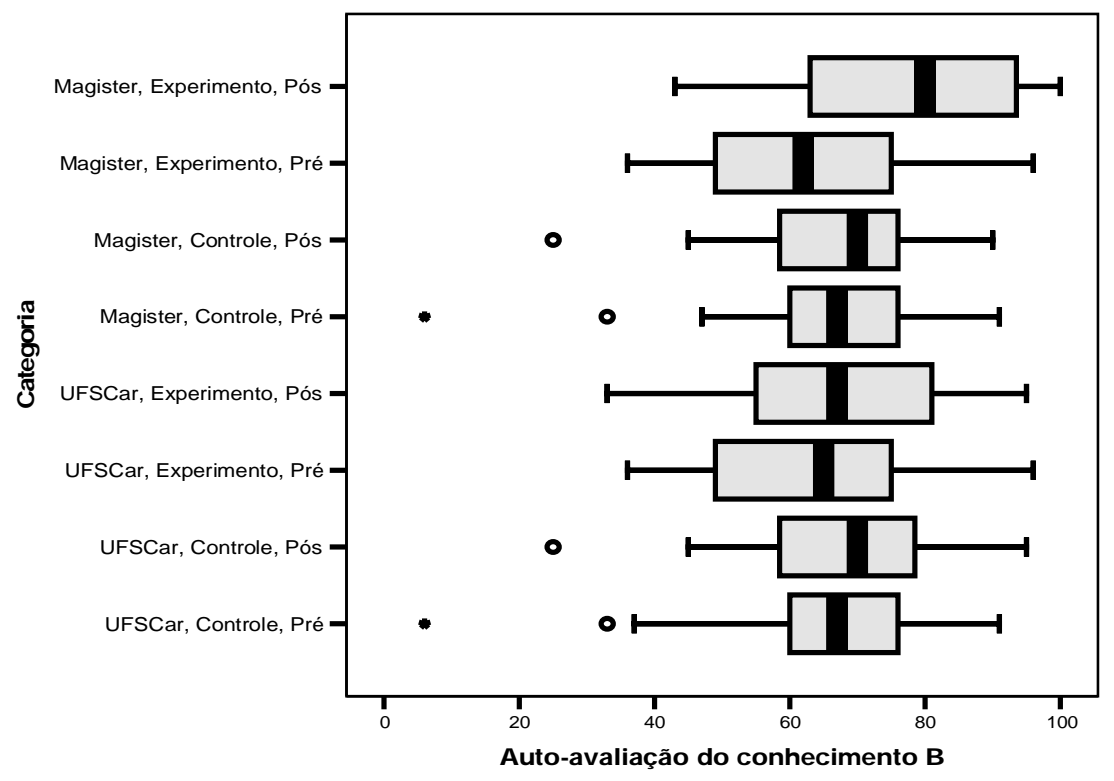


2C - Auto-avaliação do conhecimento sobre Cavernas de

Cálcário (C)

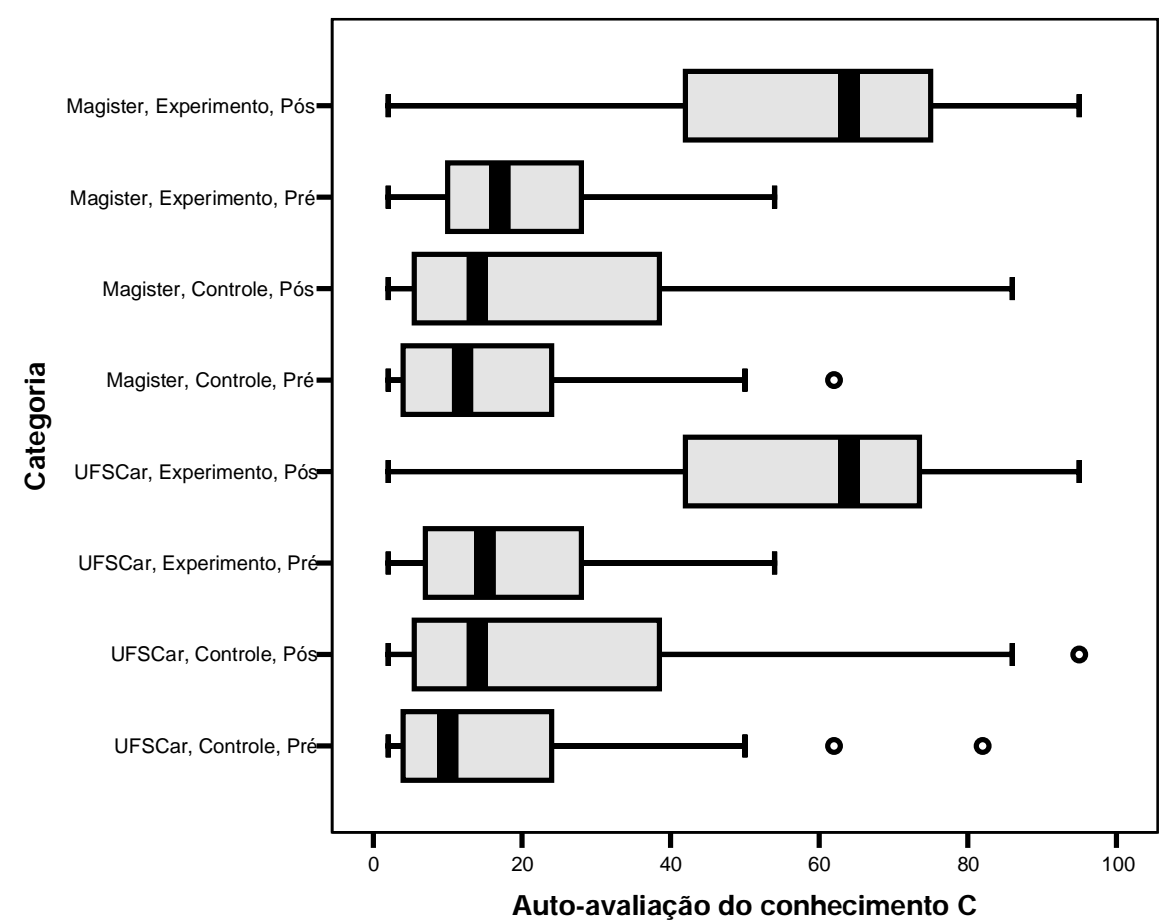

\section{D - Auto-avaliação do conhecimento sobre Unidades de Conservação (D)}

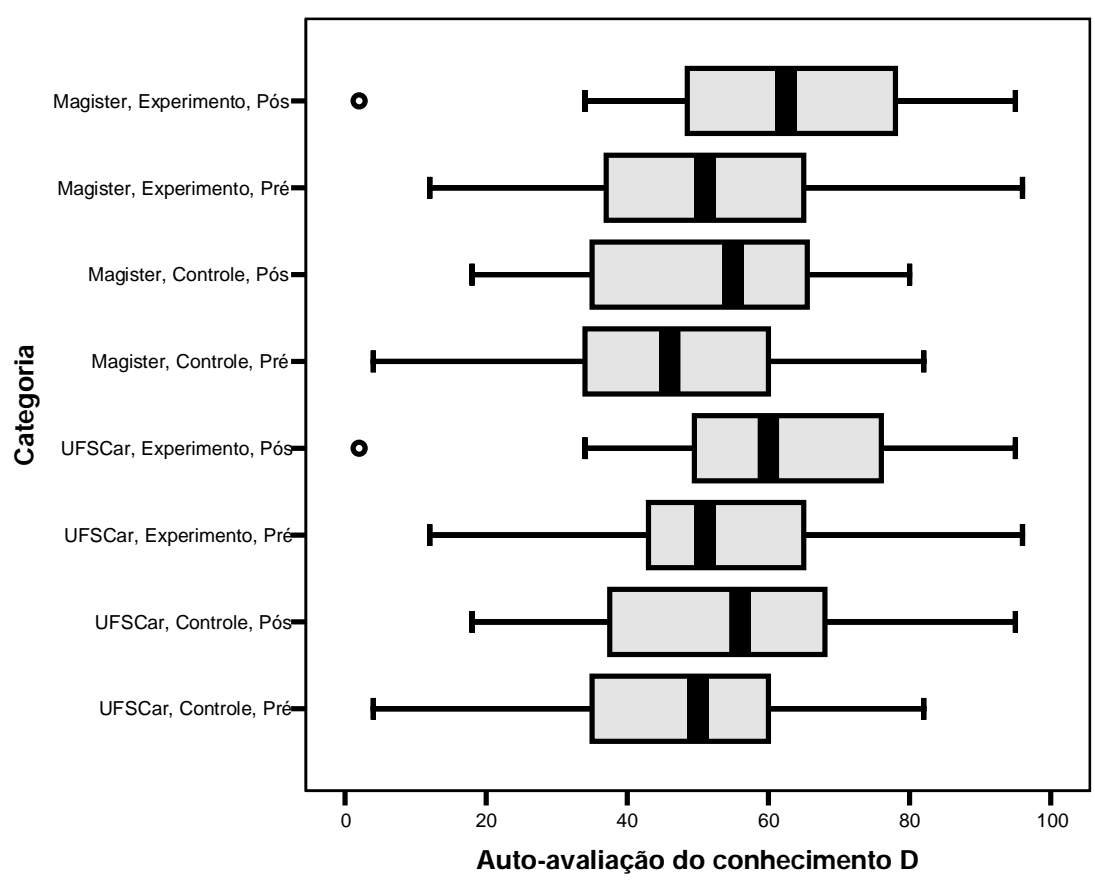




\section{E - Auto-avaliação do conhecimento Educação Ambiental (E)}

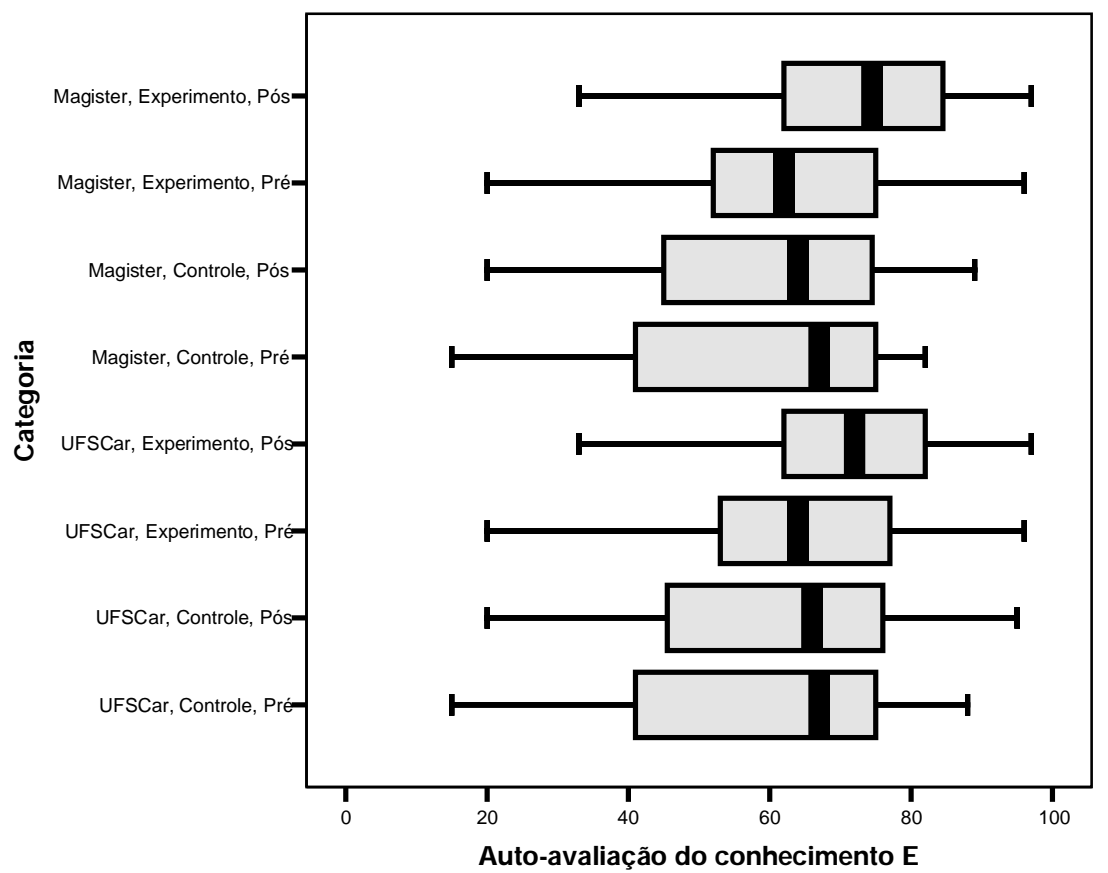




\section{F - Auto-avaliação do conhecimento sobre Comunidades Tradiciodanais $(F)$}

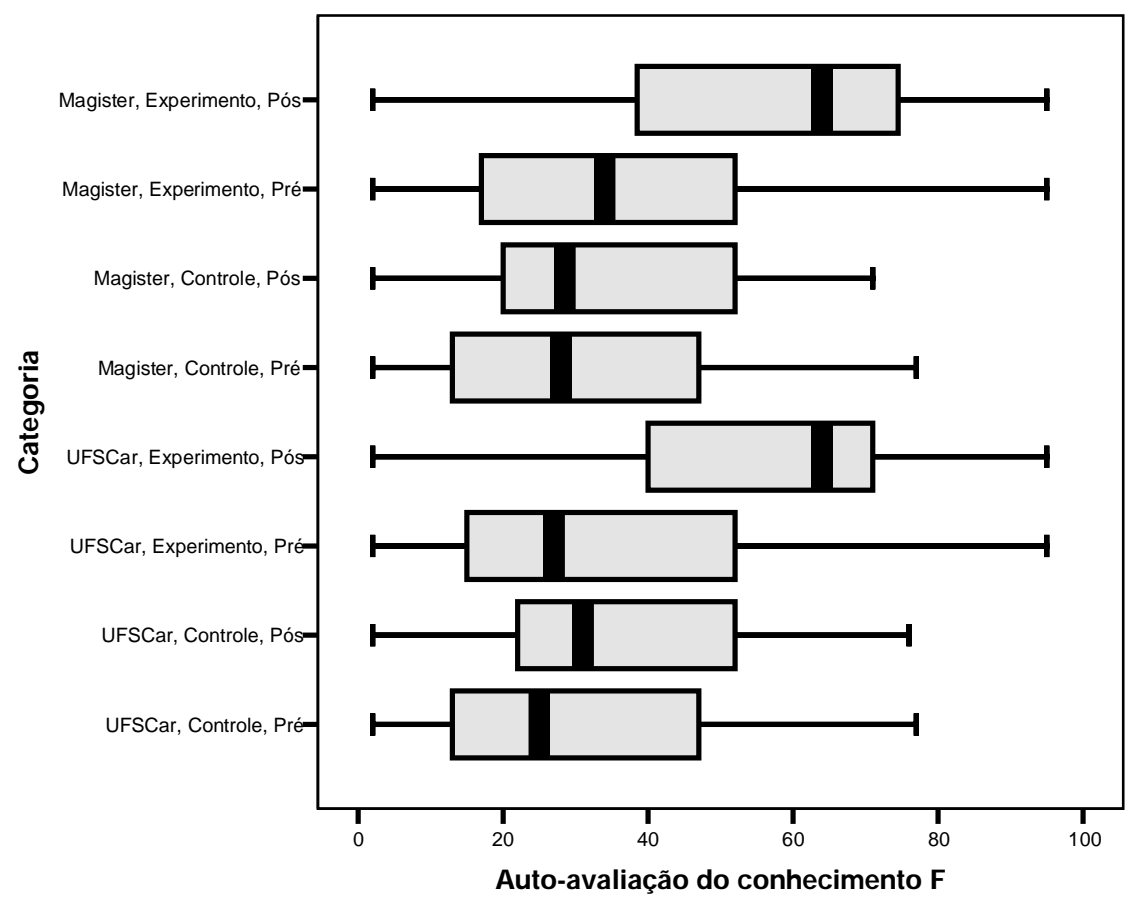




\section{$2 \mathrm{G}$ - Sentimentos entre calmo/agitado (A)}

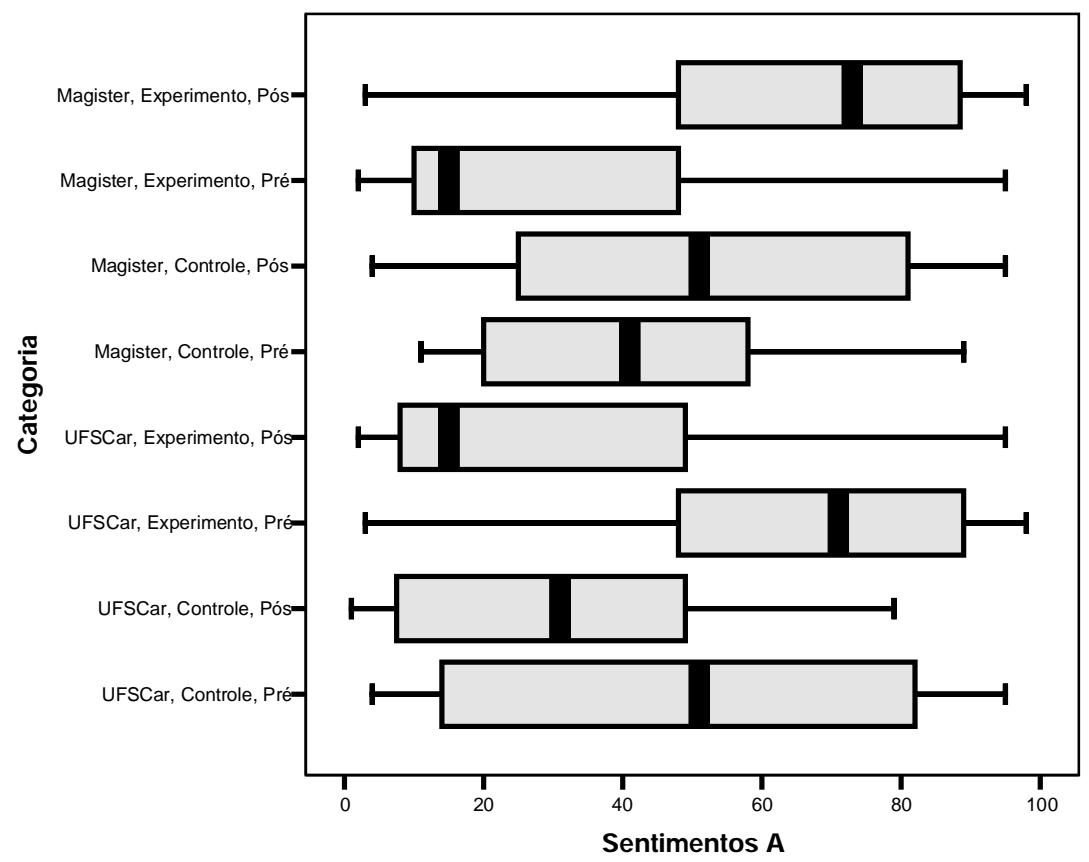

\section{$2 \mathrm{H}$ - Sentimentos dentre idéias claras/confuso (B)}

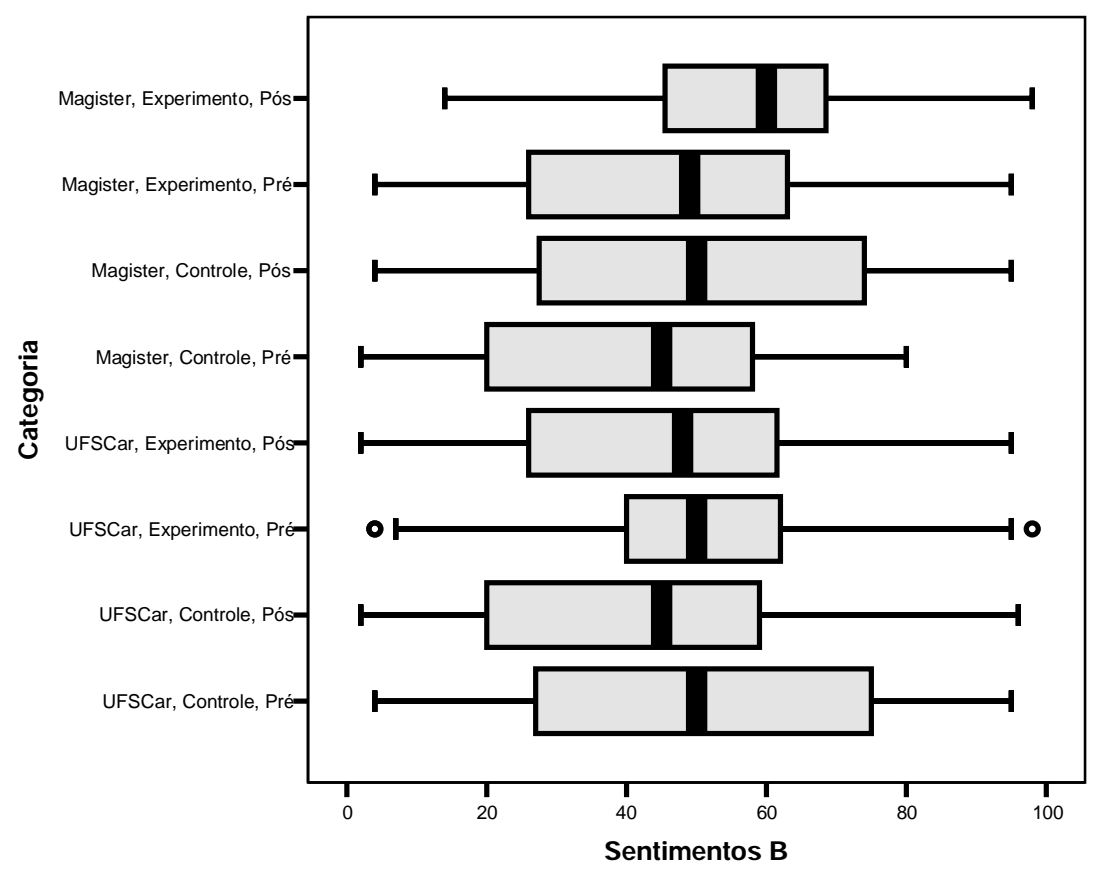




\section{I - Sentimentos entre satisfeito/insatisfeito (C)}

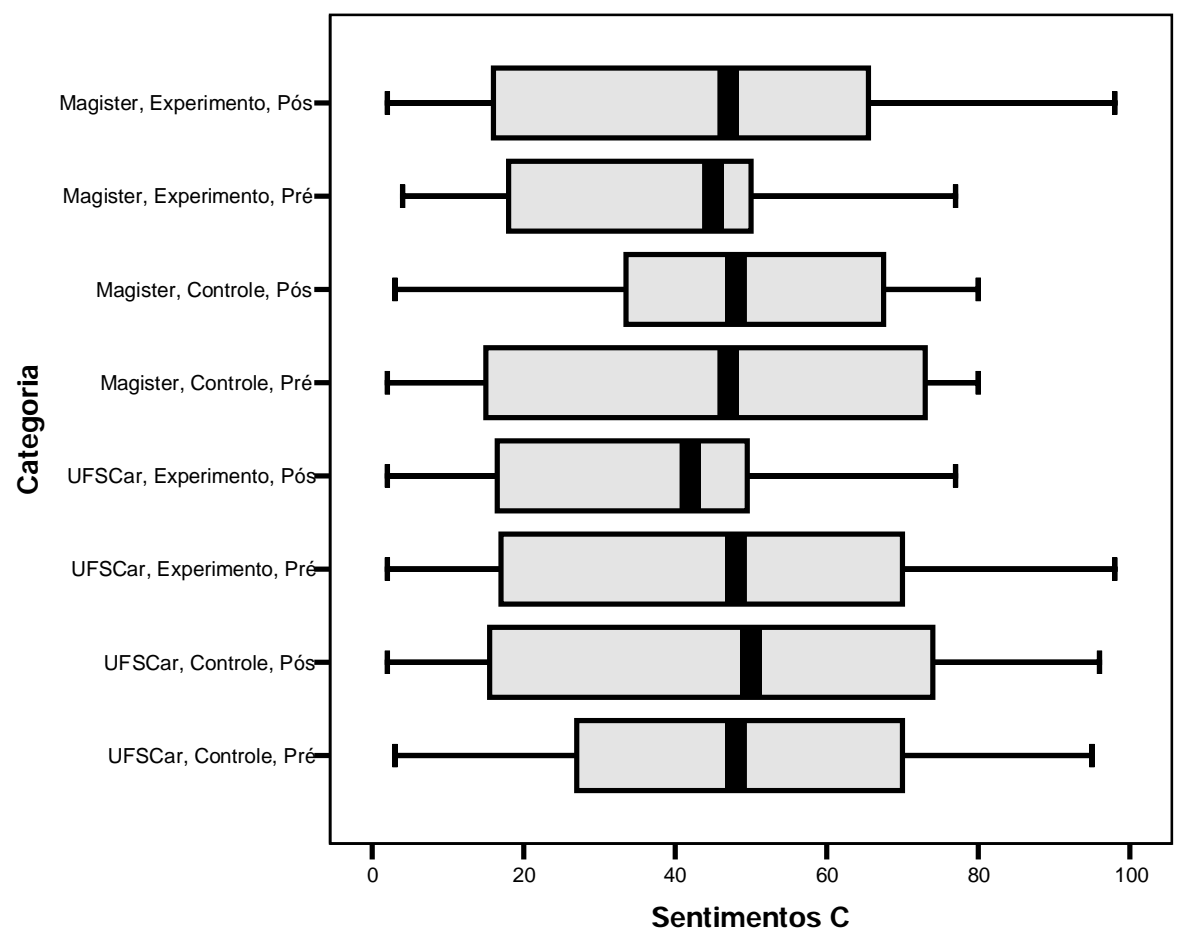

\section{J - Sentimentos entre tranquilo/preocupado (D)}

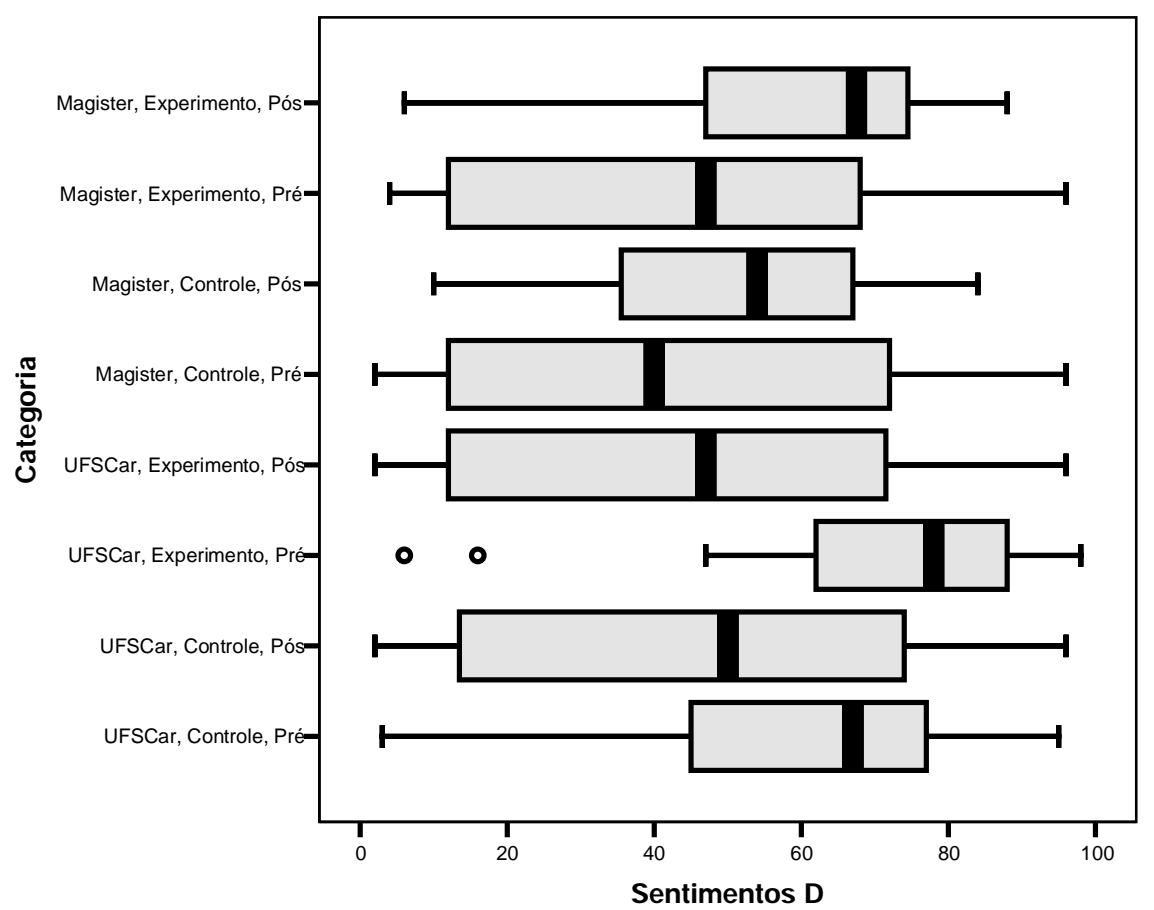




\section{K - Sentimentos entre atento/distraído (E)}

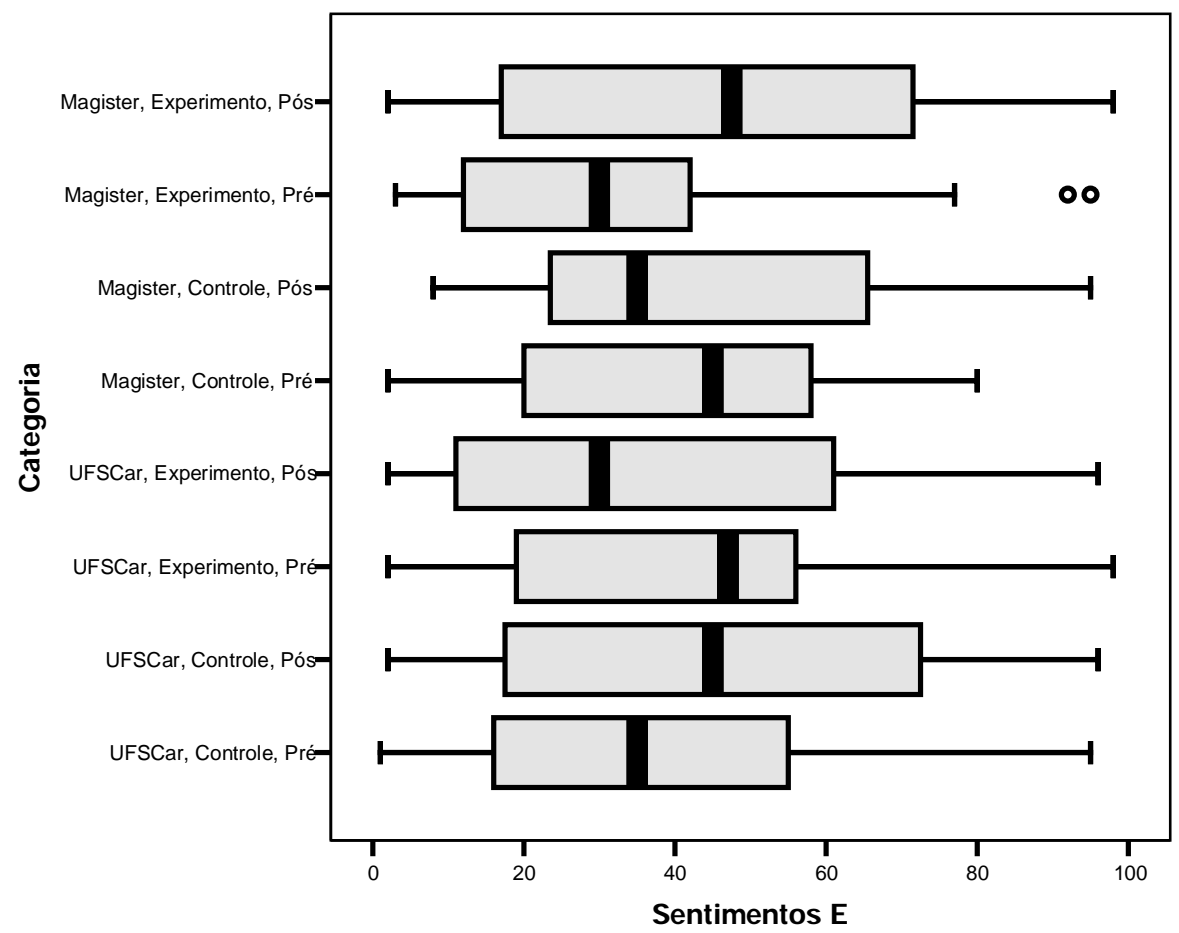

\section{$2 \mathrm{~L}$ - Sentimentos entre alegre/triste $(\mathrm{F})$}

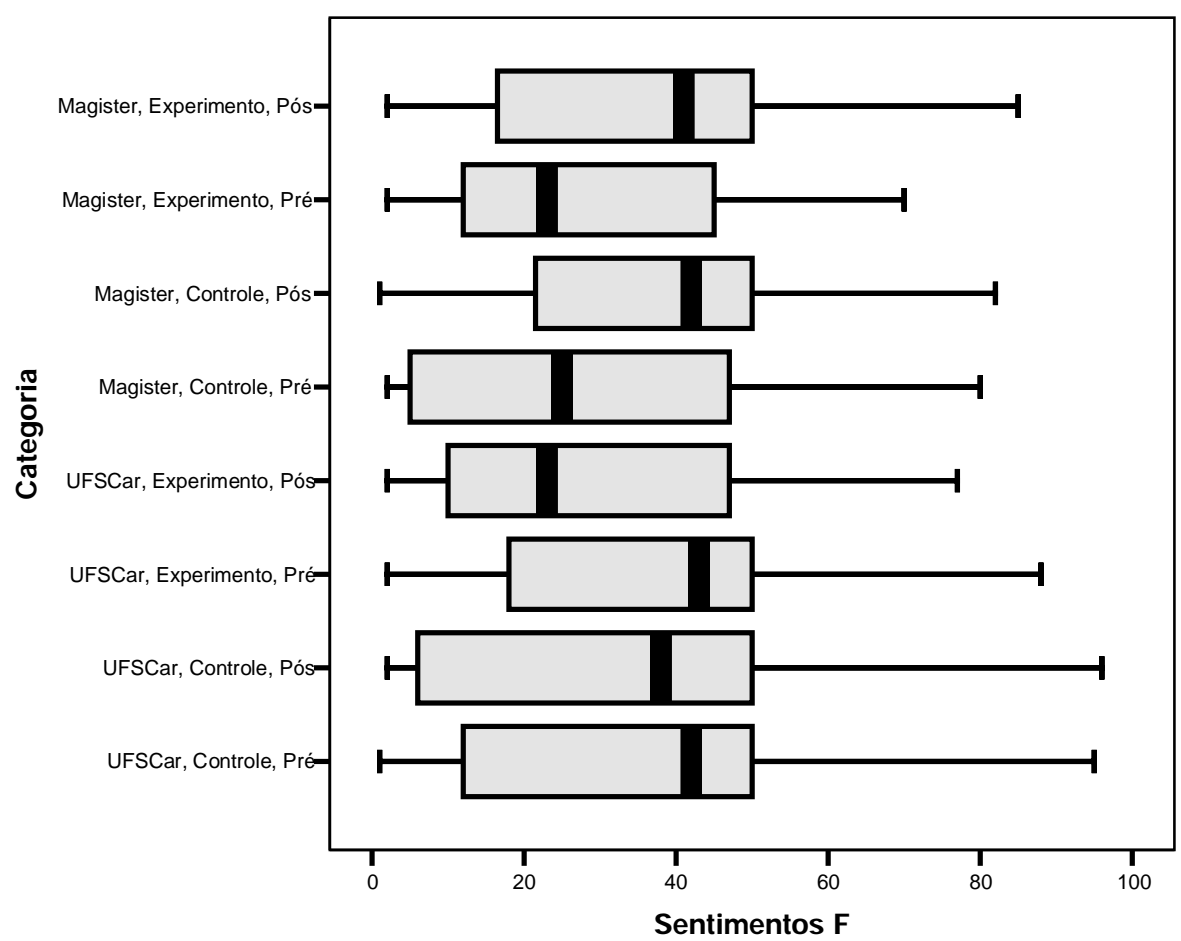




\section{M - Sentimentos entre interessado/desinteressado (G)}

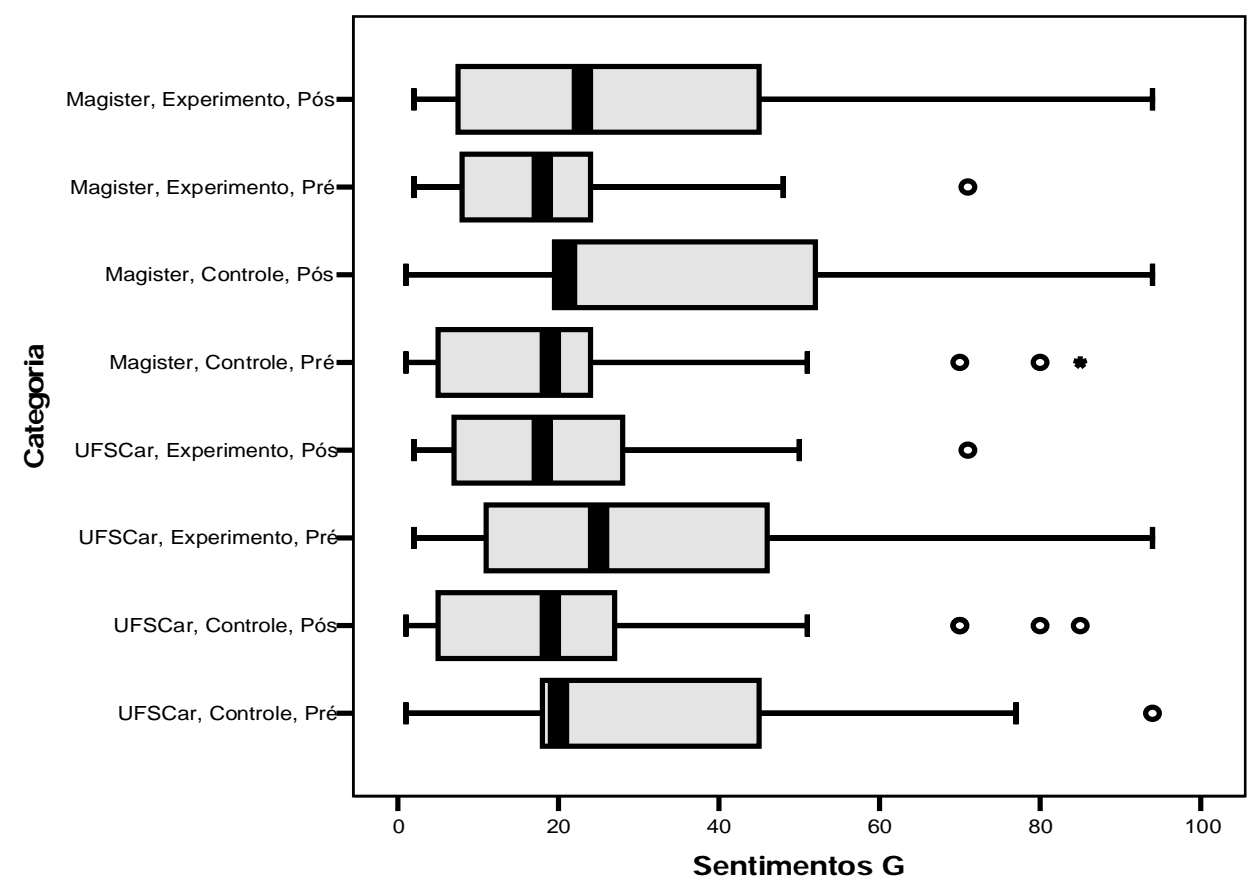

\section{$2 \mathrm{~N}$ - Sentimentos entre seguro e inseguro $(\mathrm{H})$}

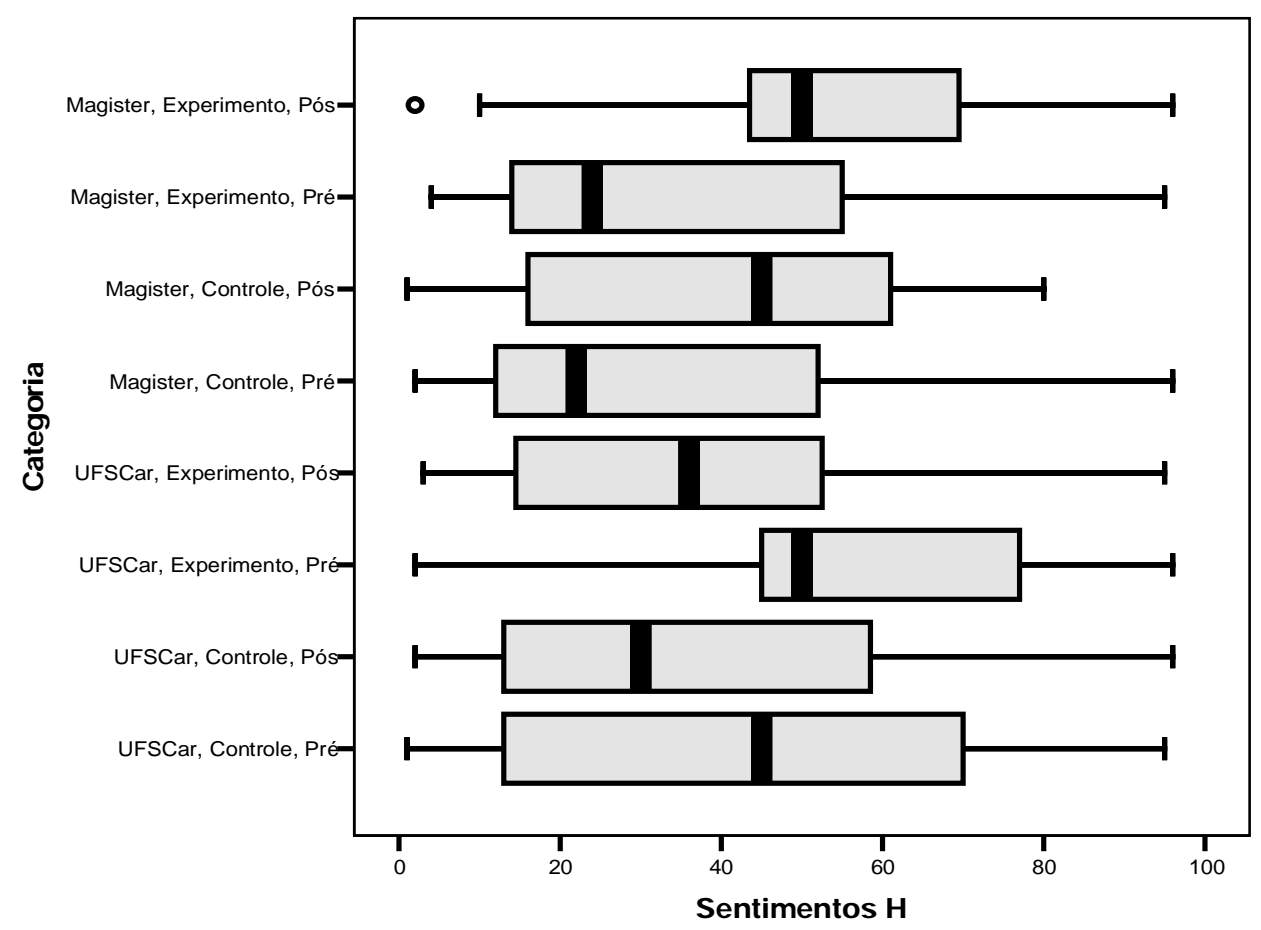




\section{0 - Sentimentos entre solitário/integrado (I)}

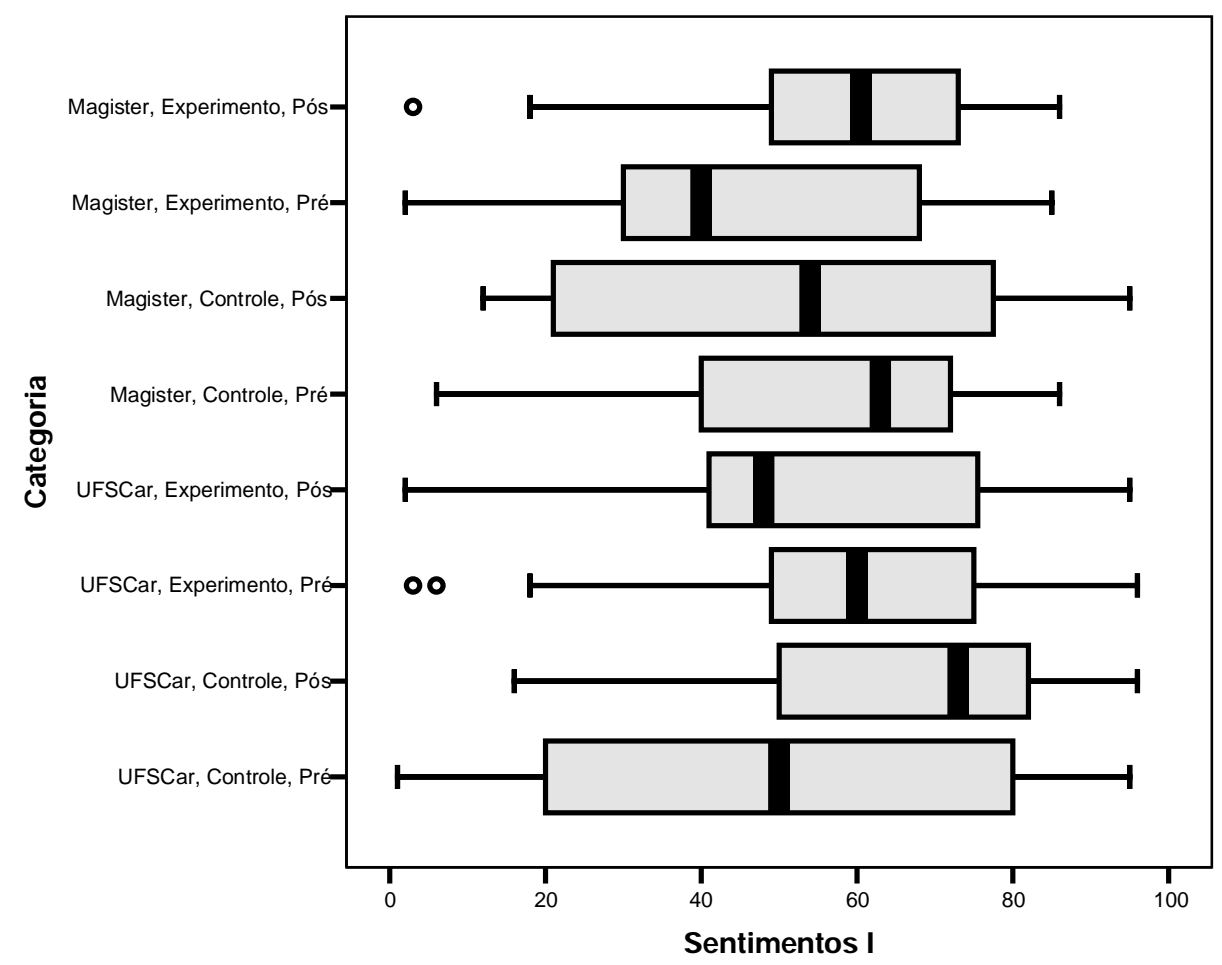

\section{P - Sentimentos entre confiante/temeroso (J )}

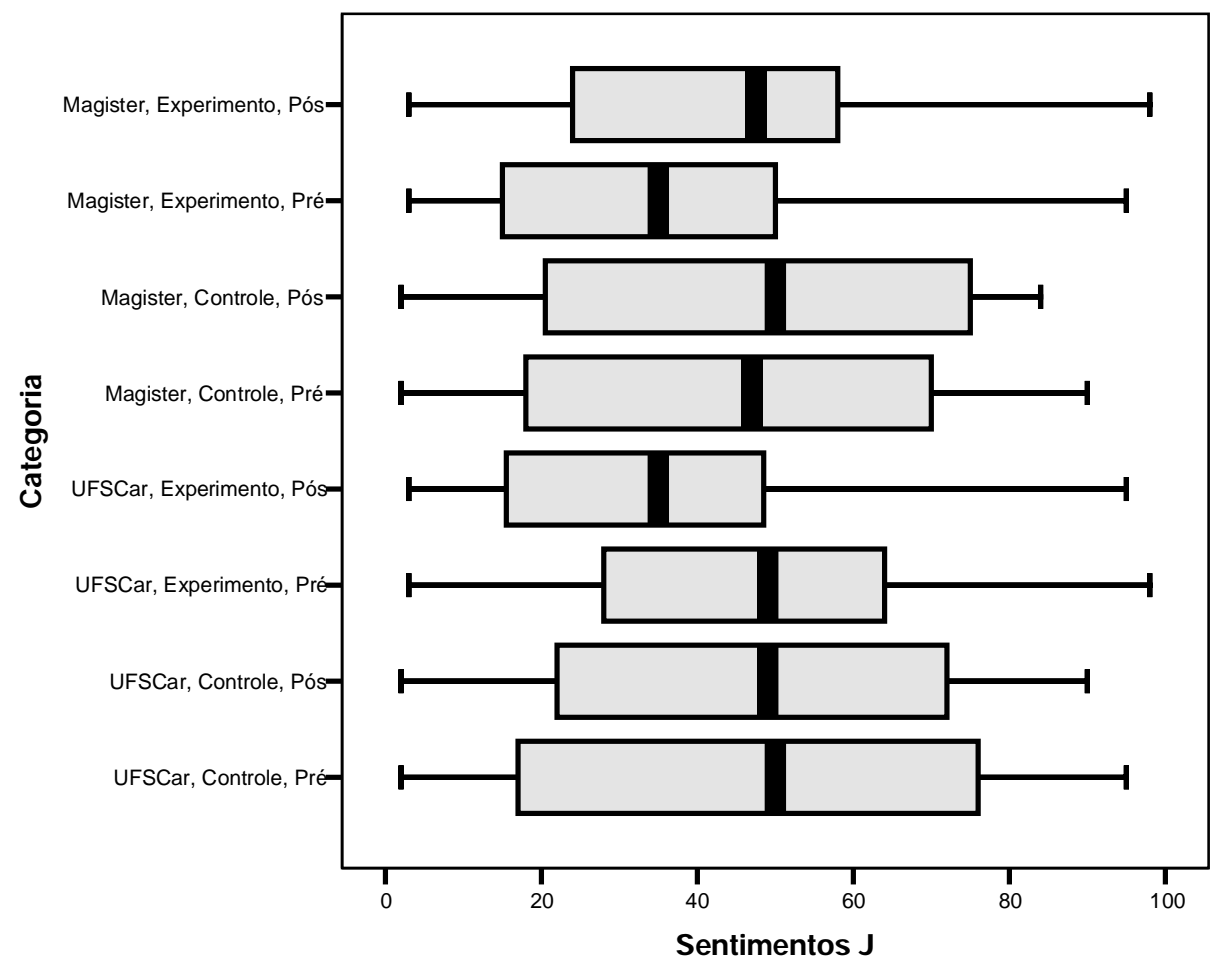




\section{Q - Sentimentos entre esperançoso/descrente (K)}

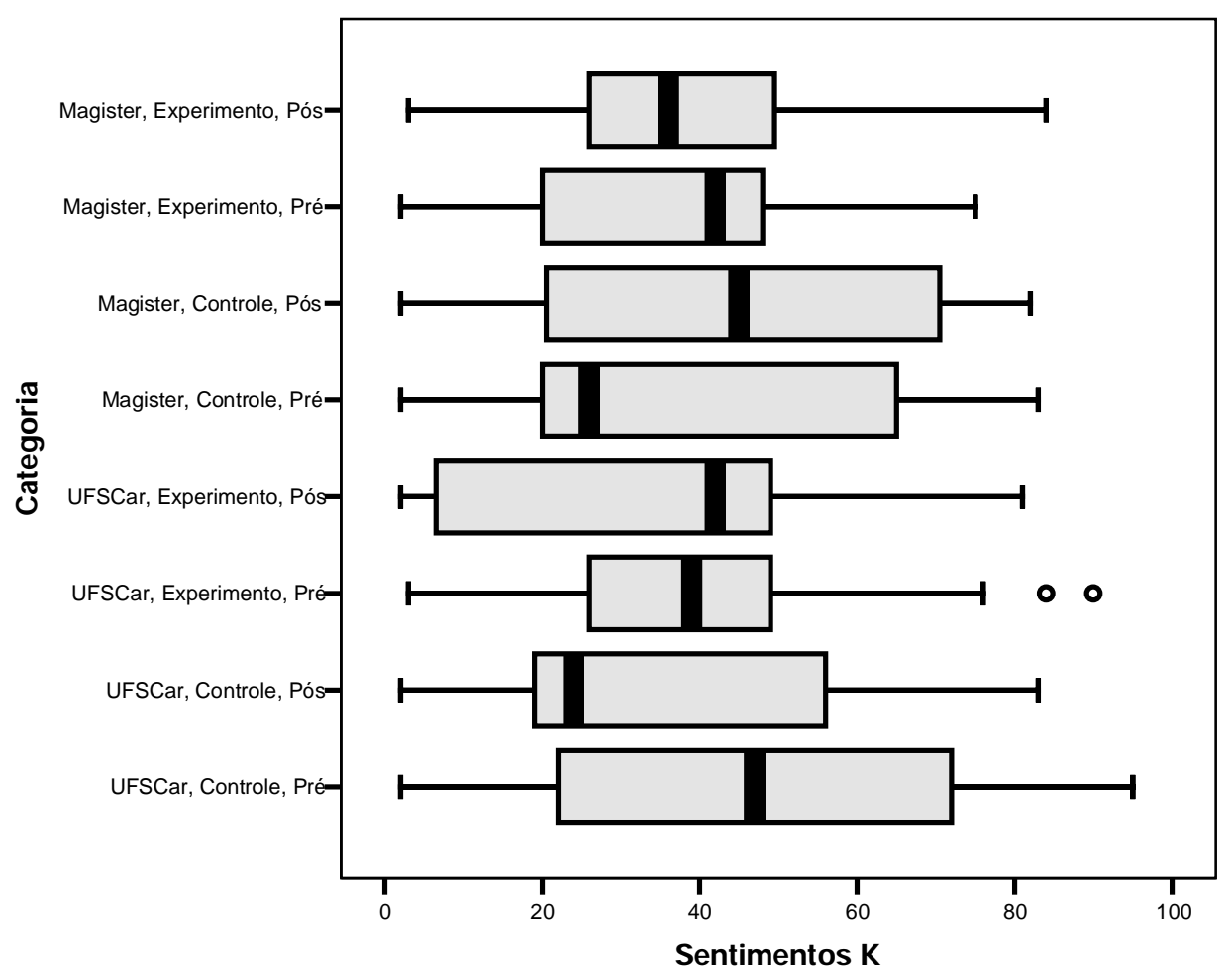




\section{R - Atitudes Pró-Ambiente A: Disposição para Participar do movimento ambientalista}

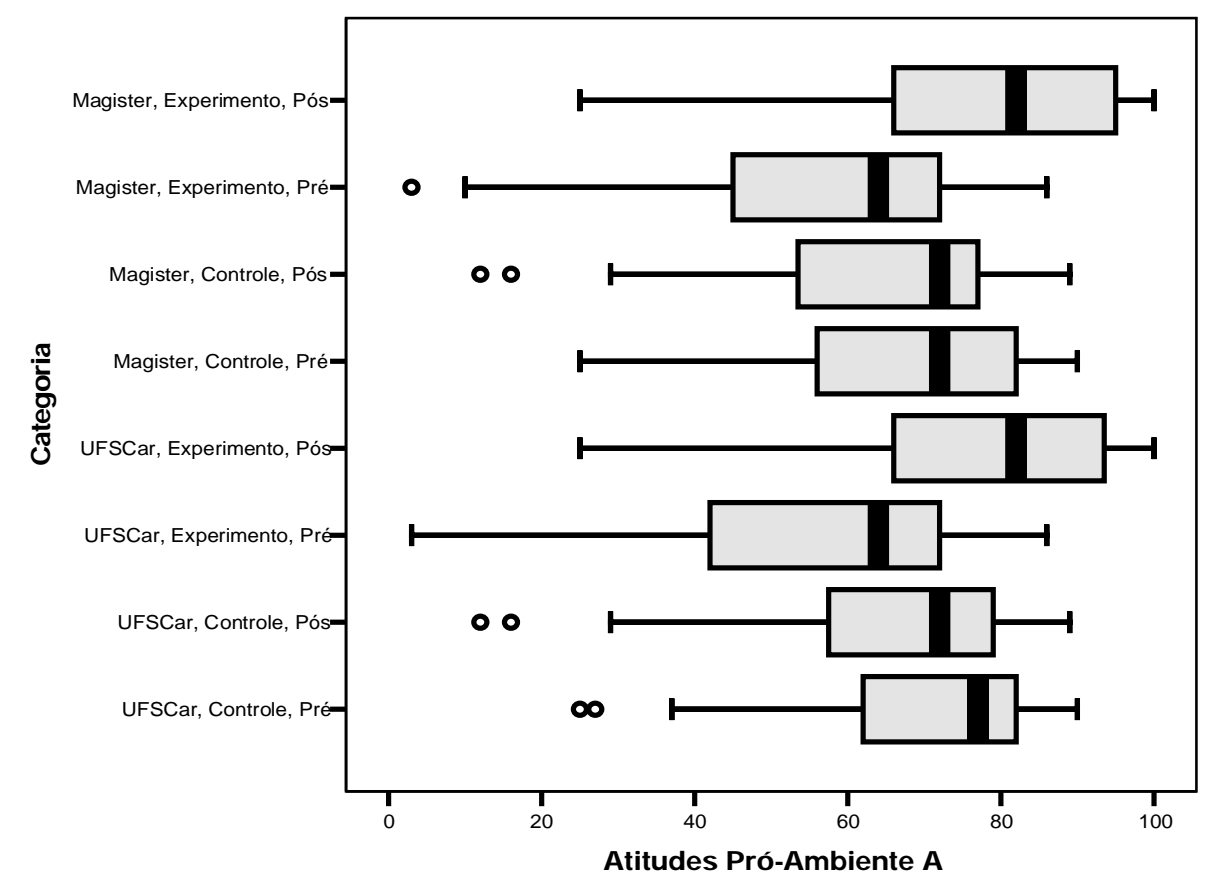

\section{S - Atitudes Pró-Ambiente B: Disposição para Mudar seus hábitos de consumo}

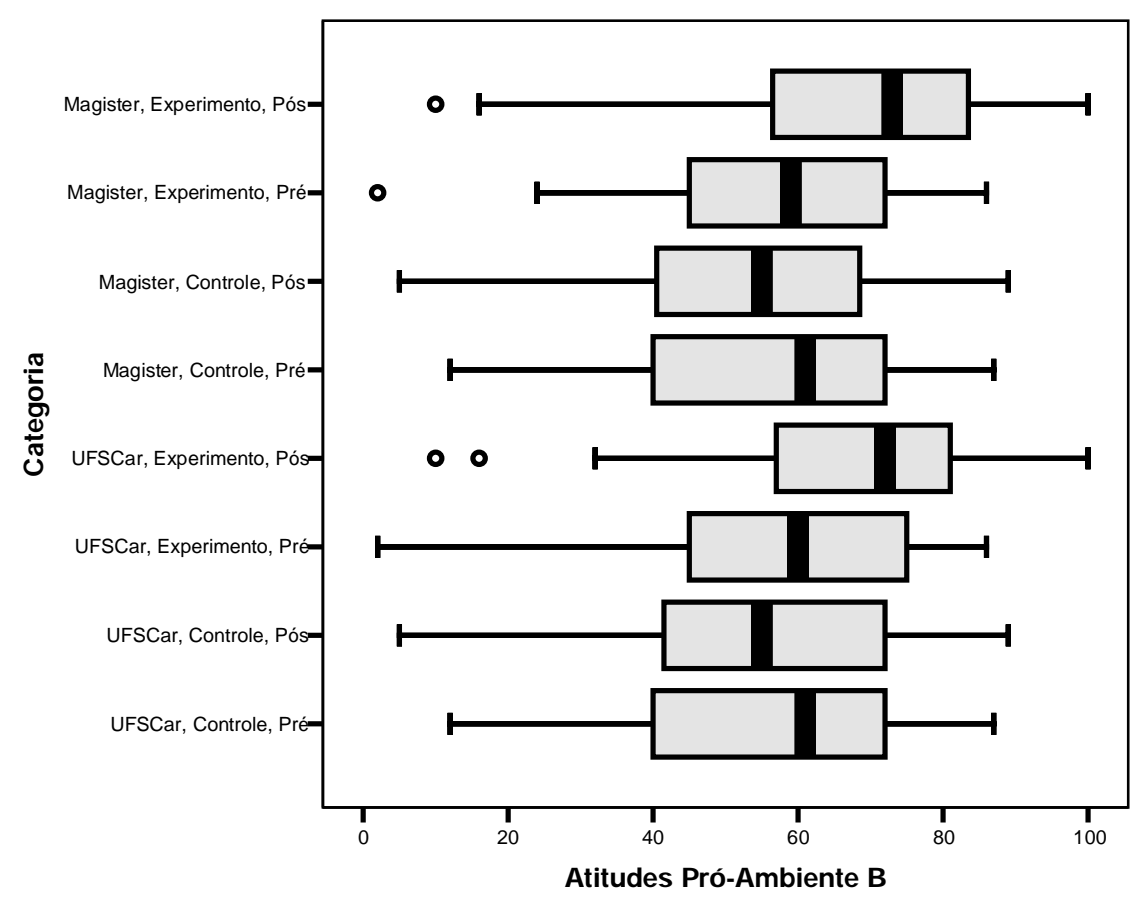




\section{T - Atitudes Pró-Ambiente C: Disposição para visitar áreas naturais}

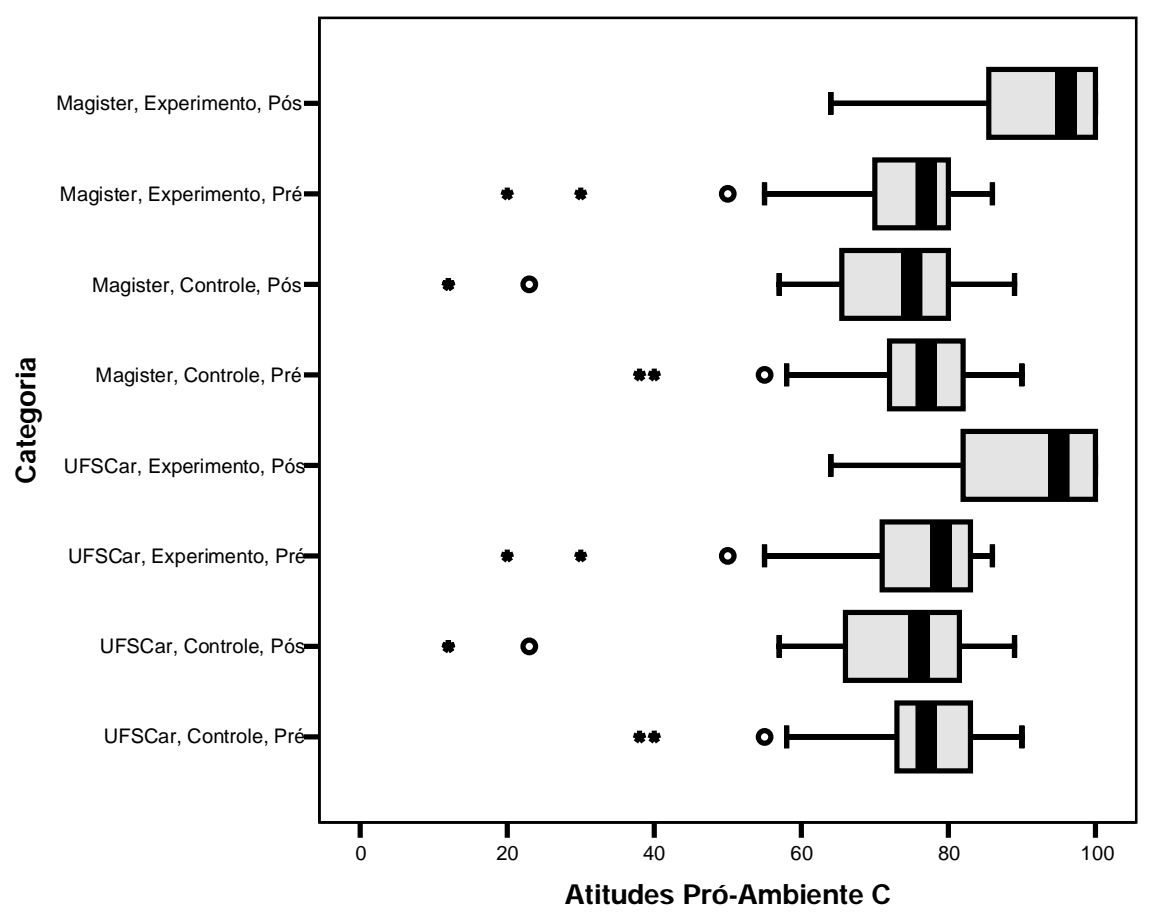




\section{$2 U$ - Atitudes Pró-Ambiente D:Disposição para usar menos o carro}

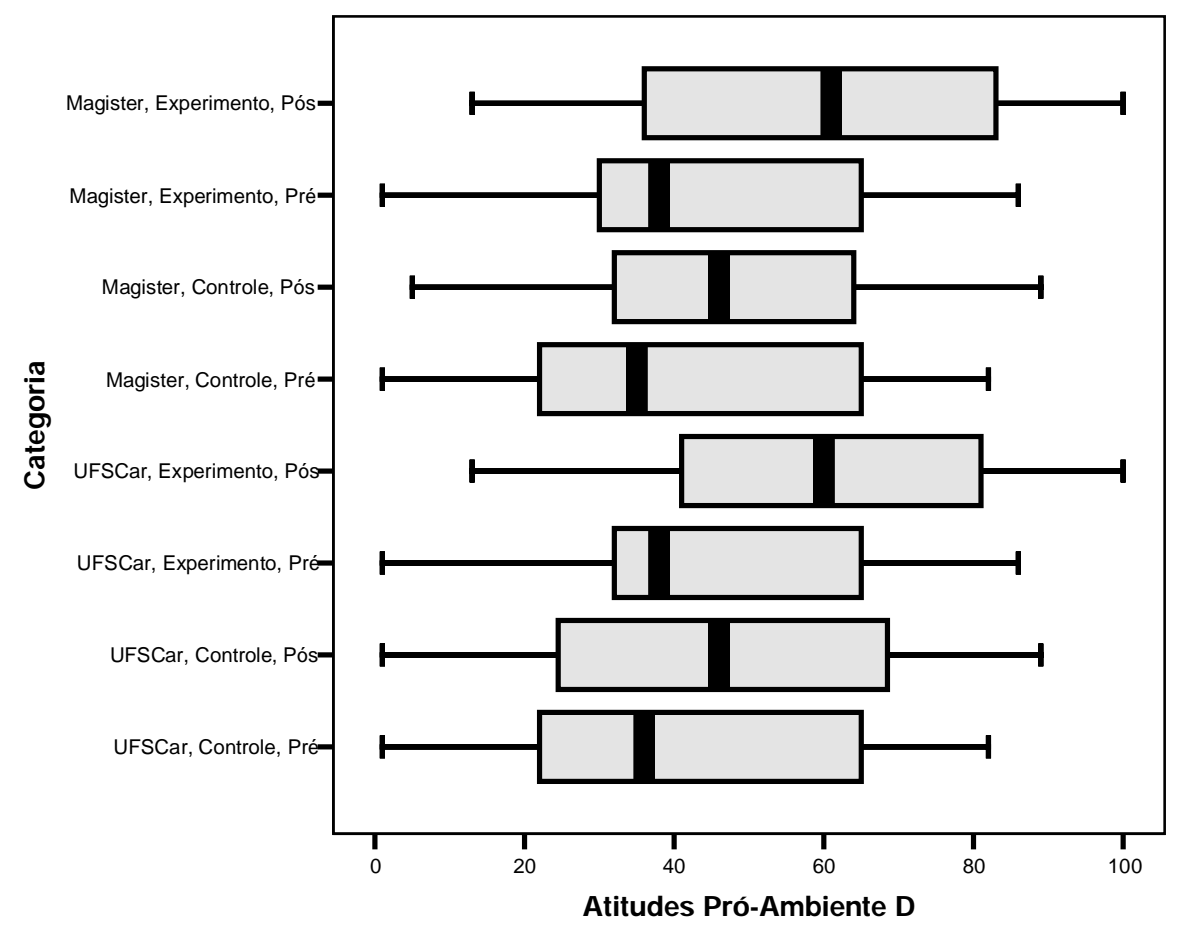




\section{W - Atitudes Pró-Ambiente E: Disposição para divulgar a preservação ambiental}

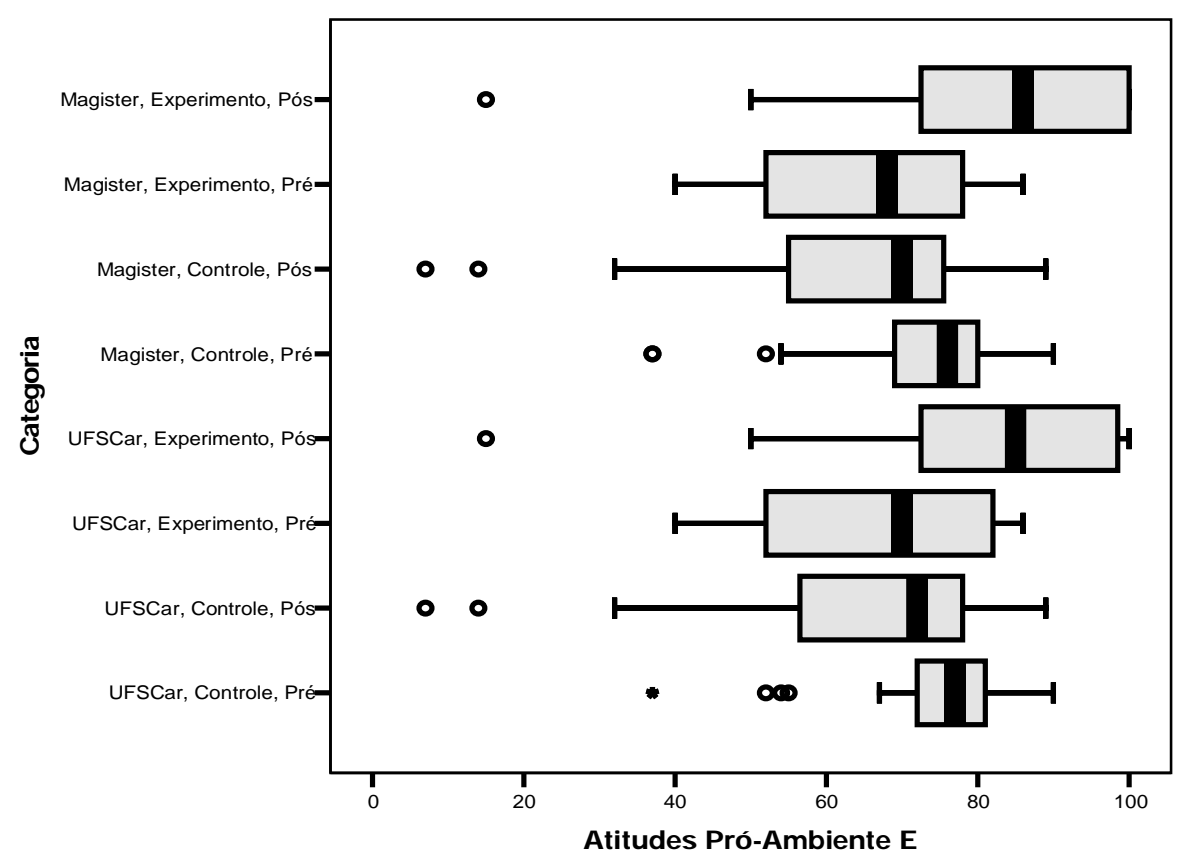

\section{X - Atitudes Pró-Ambiente F: Disposição para fazer \\ cursos na área ambiental}

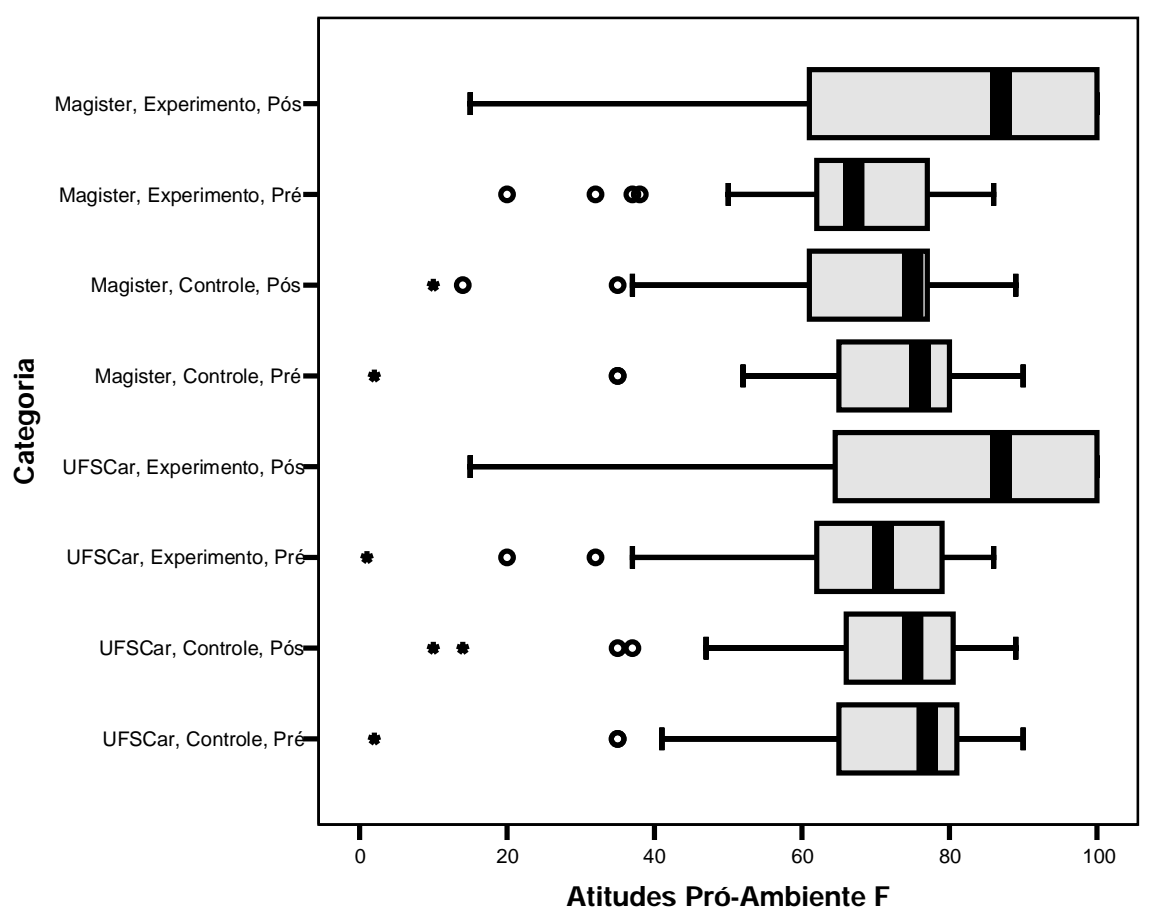




\section{Y - Atitudes Pró-Ambiente G: Disposição para Pesquisar} e escrever artigos sobre Meio Ambiente

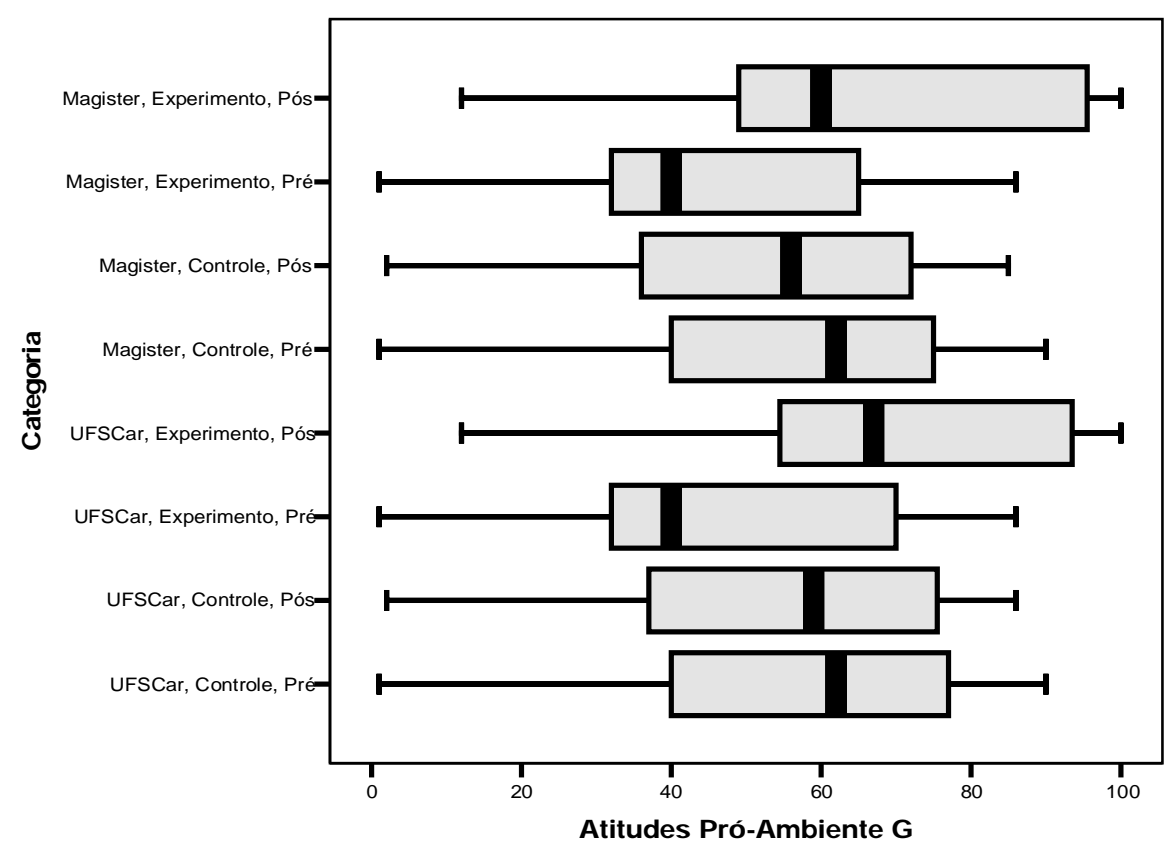

$2 Z$ - Atitudes Pró-Ambiente H: Disposição para Rever seus hábitos cotidianos de modo a economizar recursos

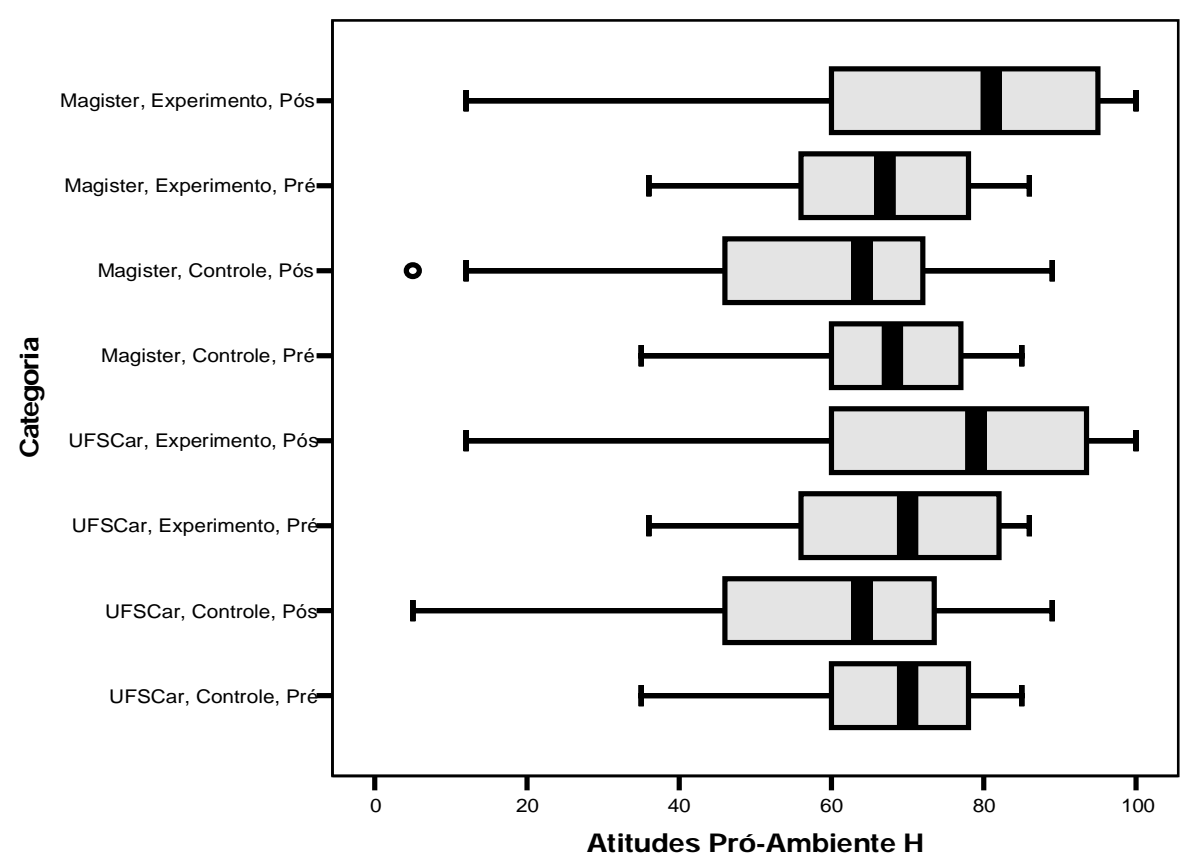




\section{AA - Atitudes Pró-Ambiente I: Disposição para Ler a} respeito ou assistir documentários sobre meio ambiente

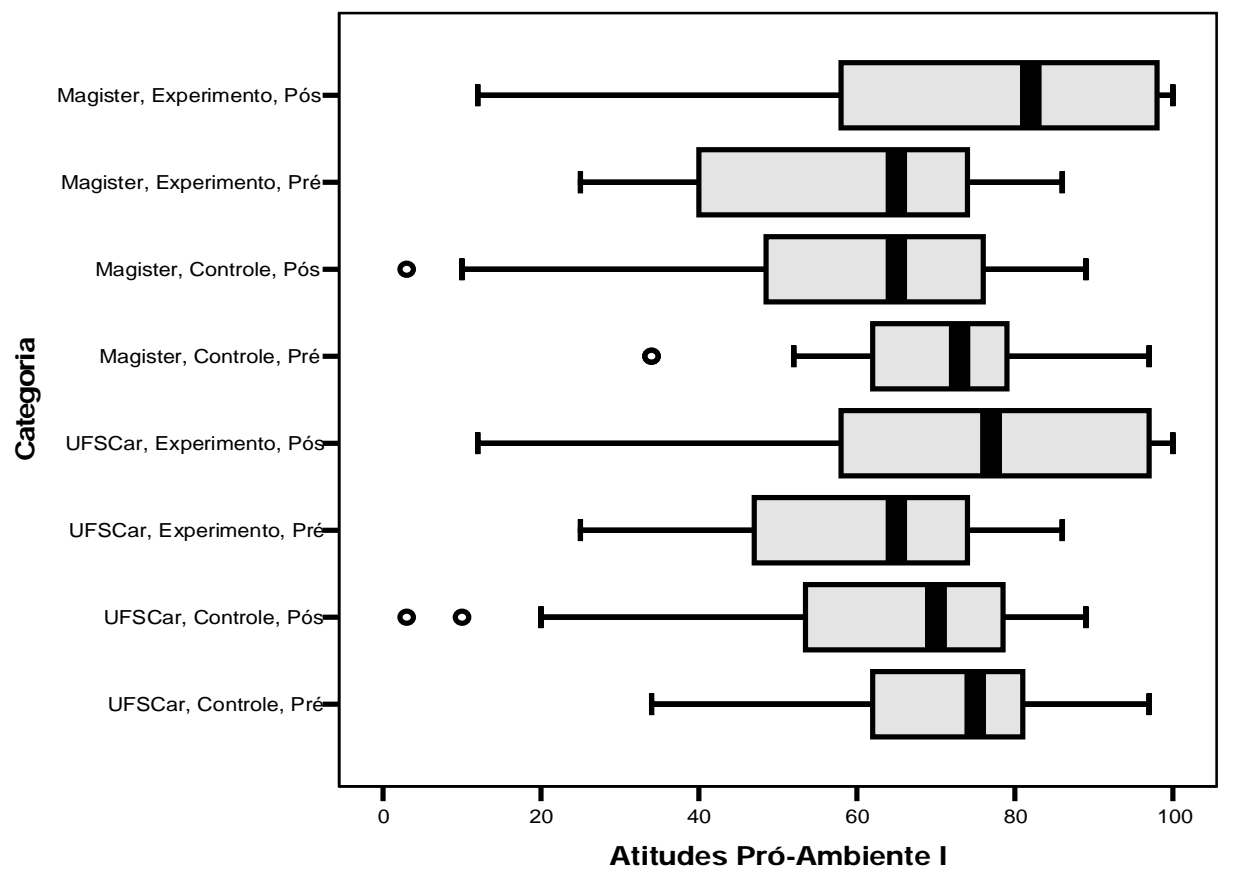

2AB - Atitudes Pró-Ambiente J : Disposição para Ser mais integrado às outras pessoas

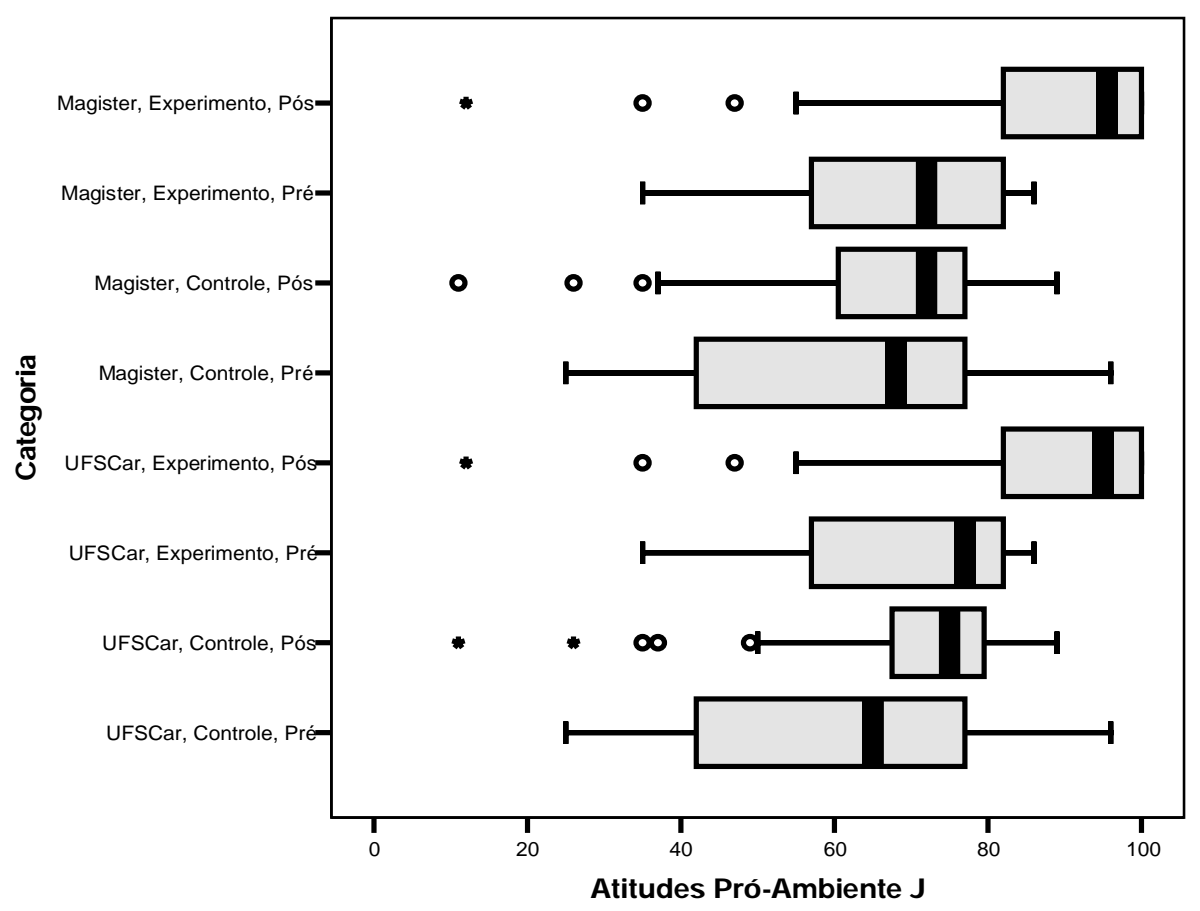




\section{AC - Atitudes Pró-Ambiente K: Disposição para espiritualizar-se}

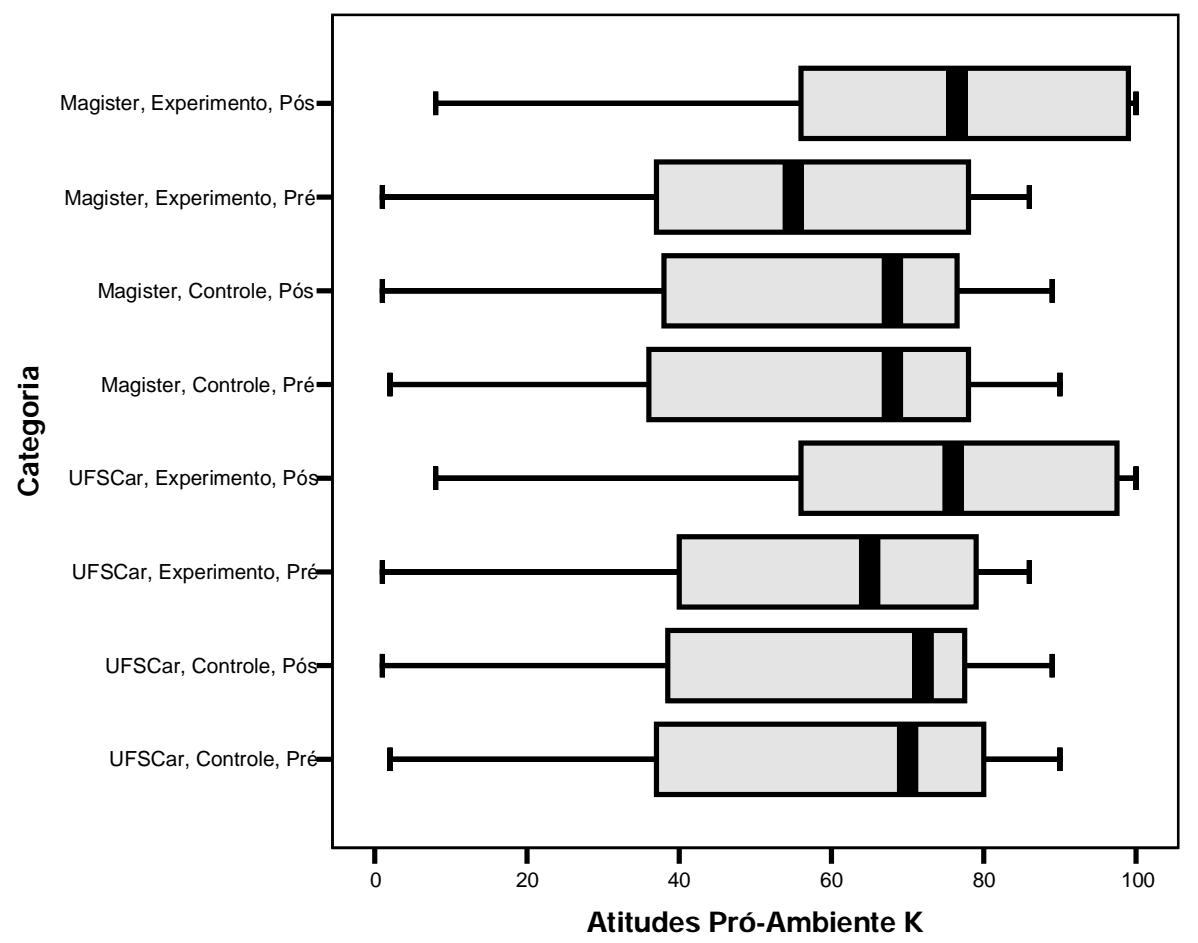




\section{AD - Atitudes Pró-Ambiente L: Disposição para Cuidar de plantas e animais}

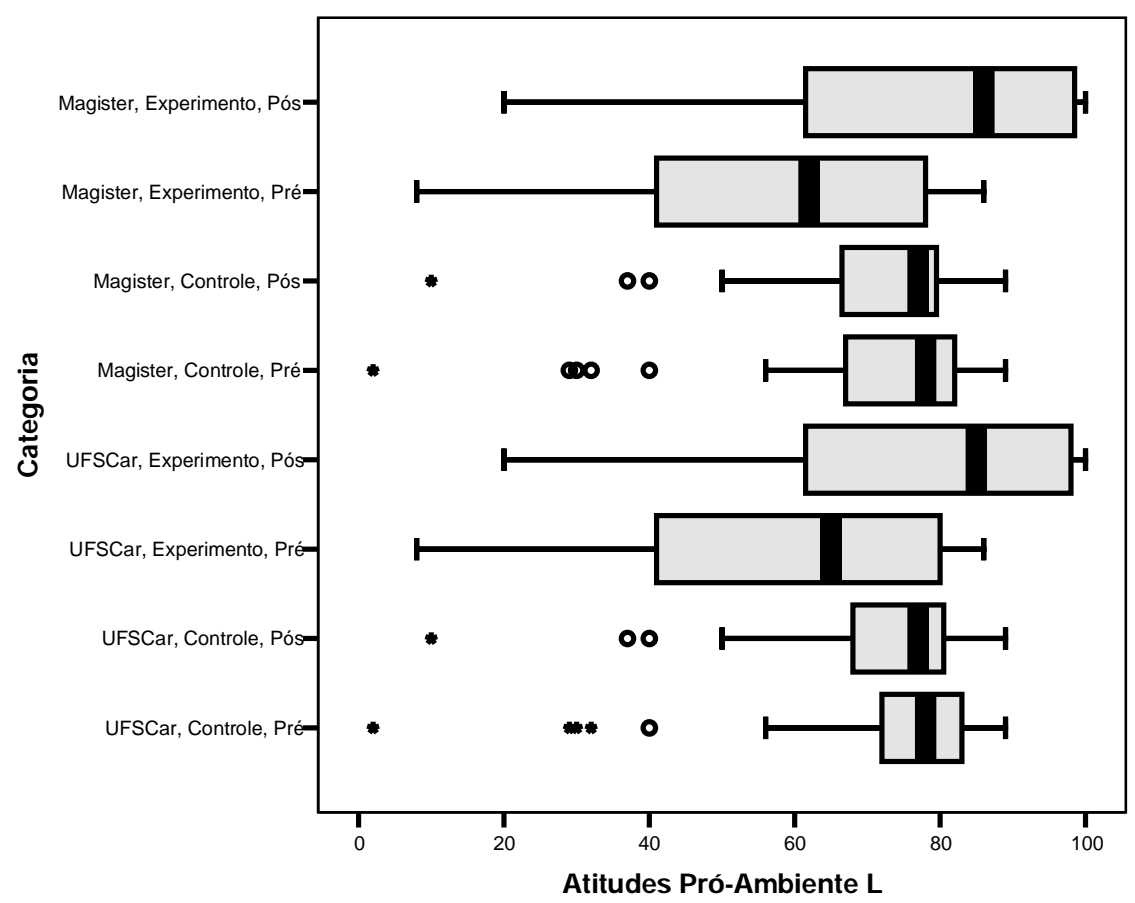

2AE - Atitudes Pró-Ambiente M: Disposição para Reciclar o lixo

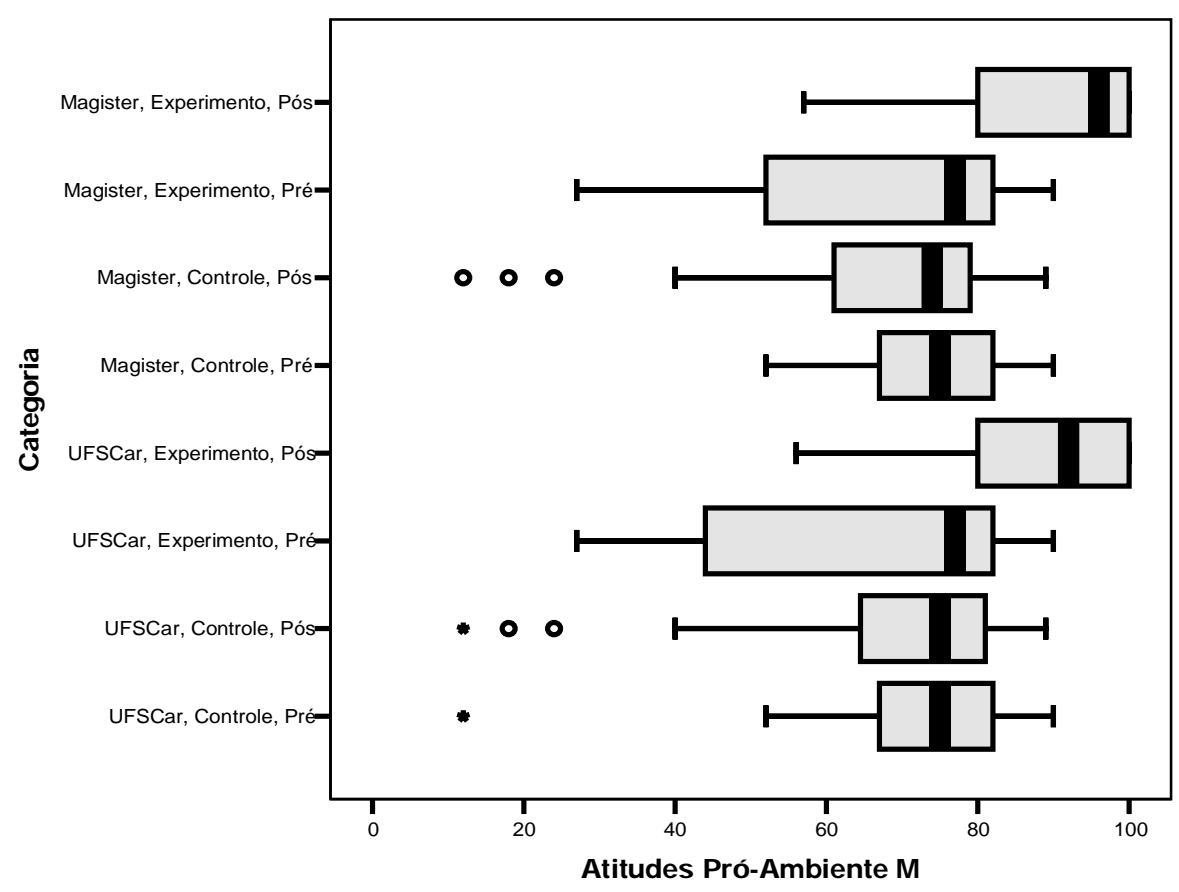




\section{AF - Atitudes Pró-Ambiente N: Disposição para Filiar-se a uma ONG ambientalista}

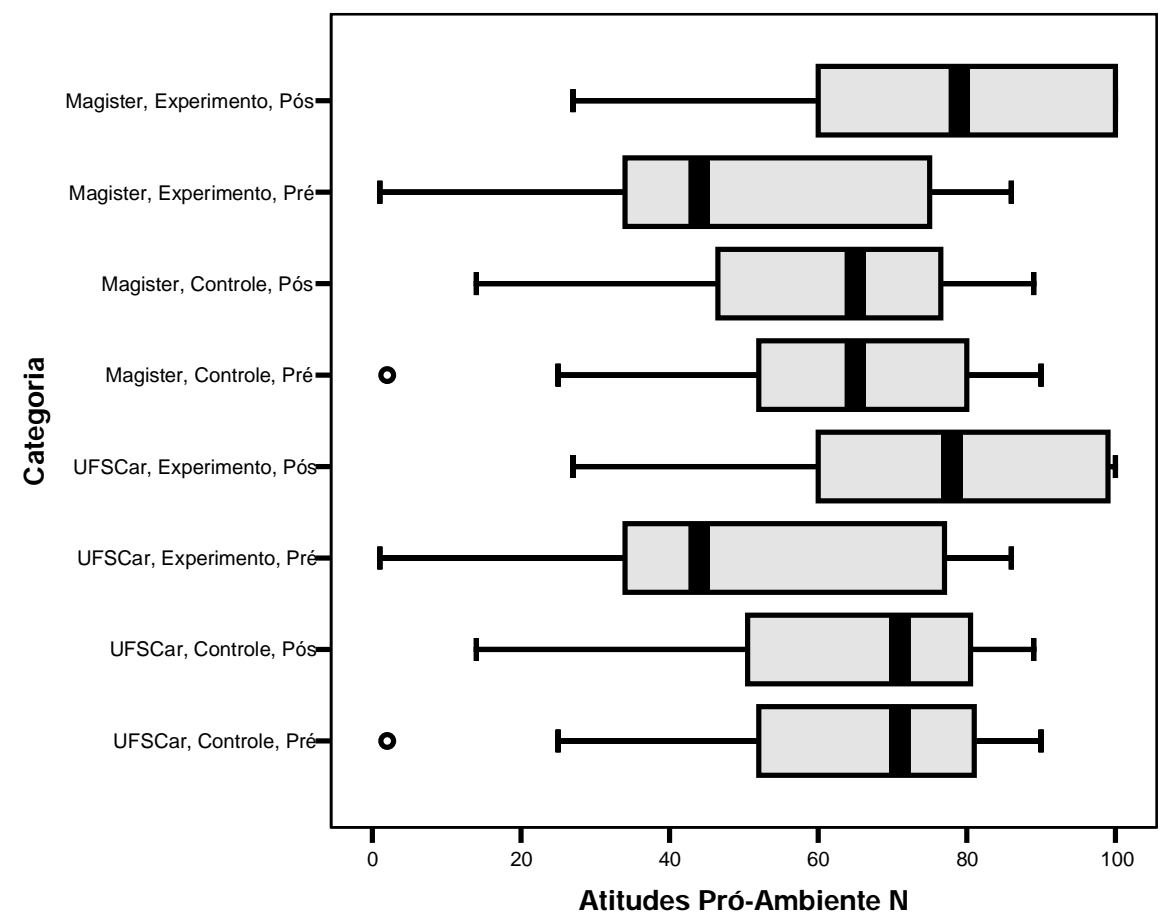




\section{AG - Atitudes Pró-Ambiente O: Disposição para doar recursos ou trabalhar voluntariamente para a Conservação Ambiental}

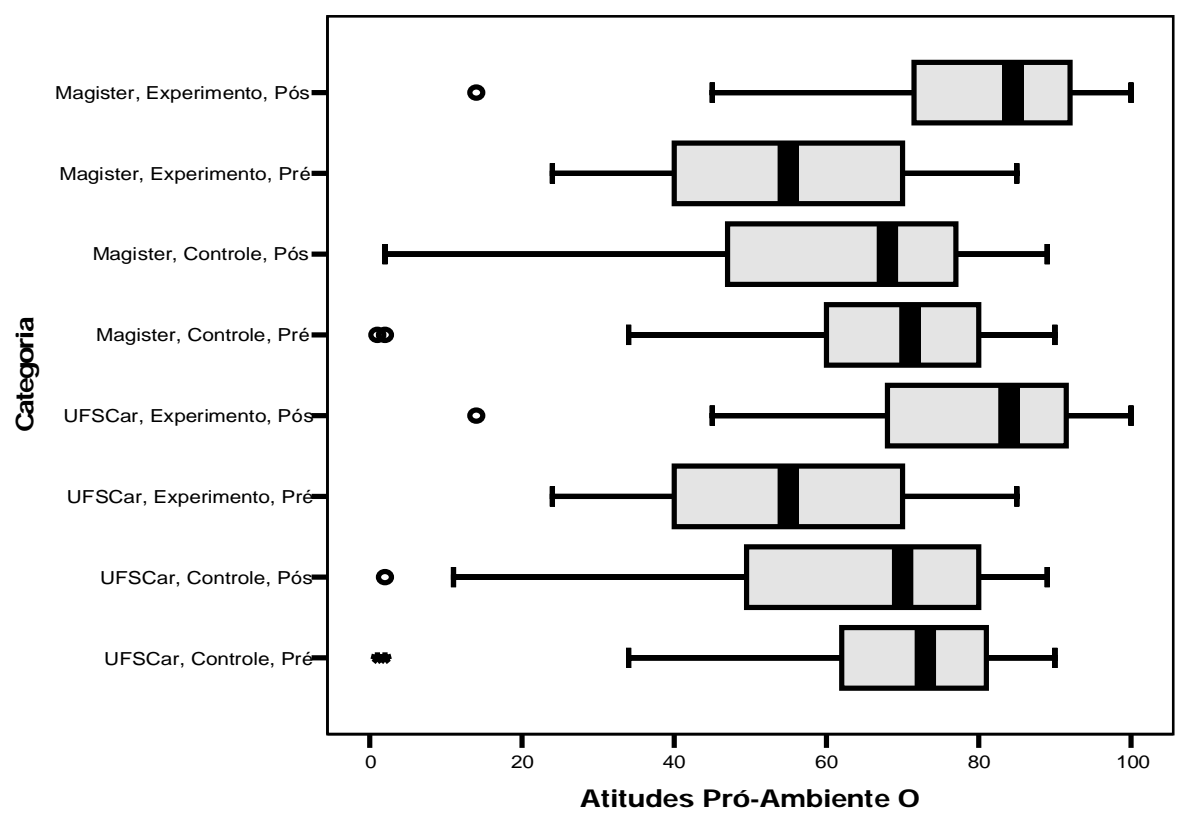


2AH - Atitudes Pró-Ambiente P: Disposição para pagar mais impostos, desde que sejam revertidos para Conservação Ambiental.

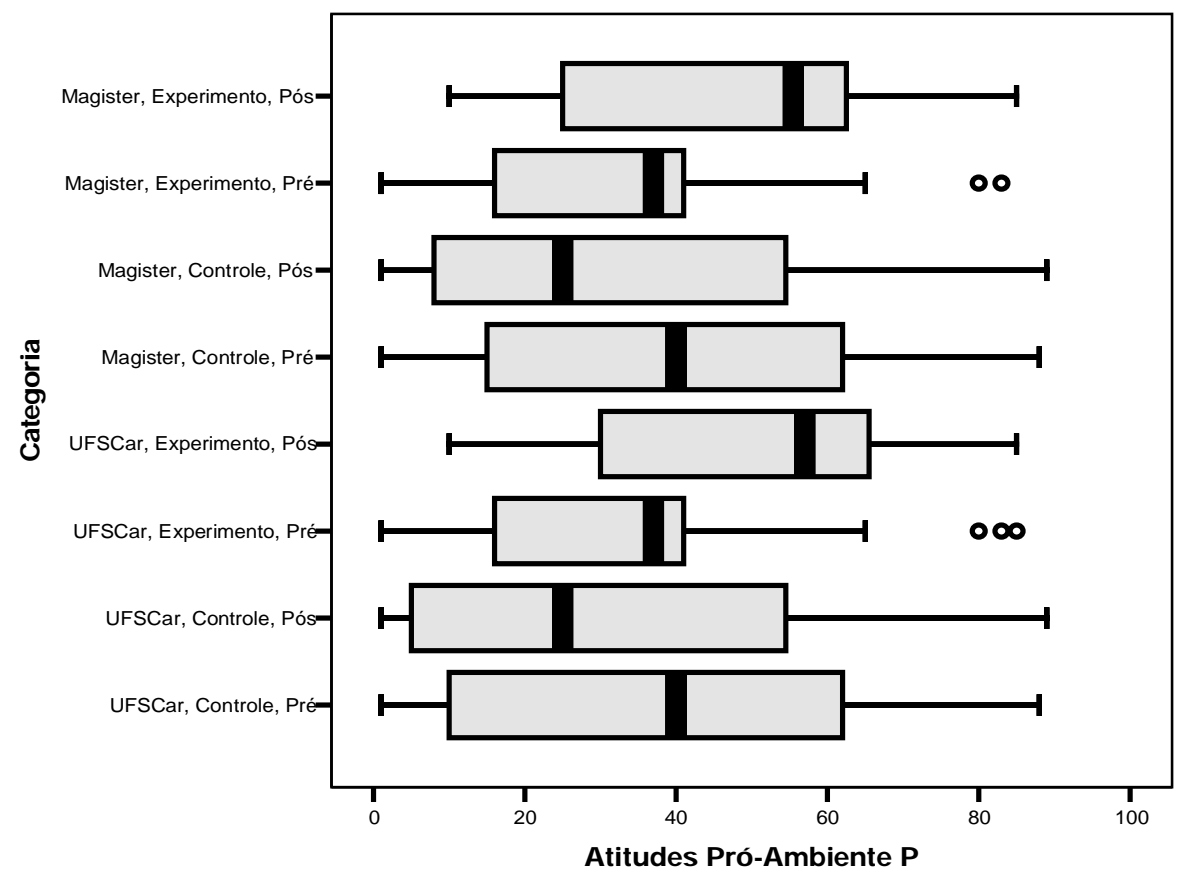

2Al - Percepções A: O que você acha da relação dos animais da mata com o homem? (boa/ruim)

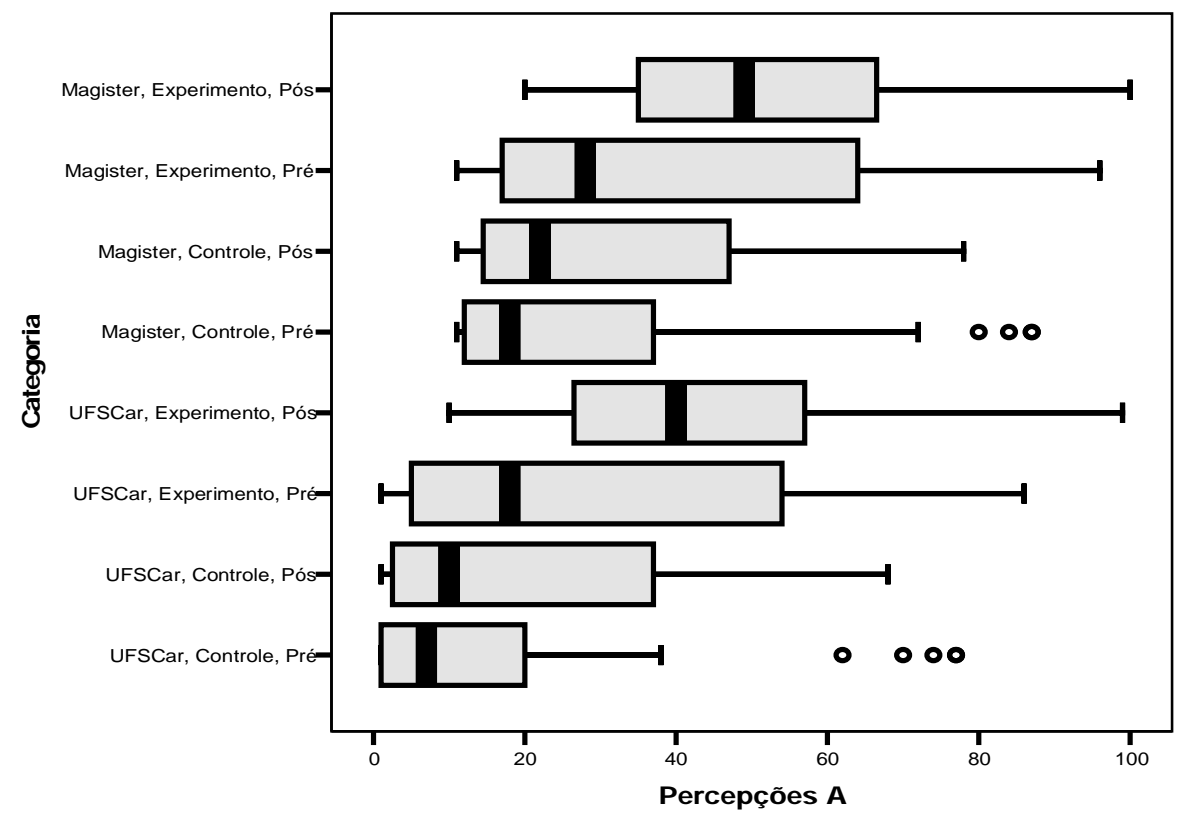


2AJ - Percepções B: O que você sente quando ouve falar sobre a extinção de plantas e animais?

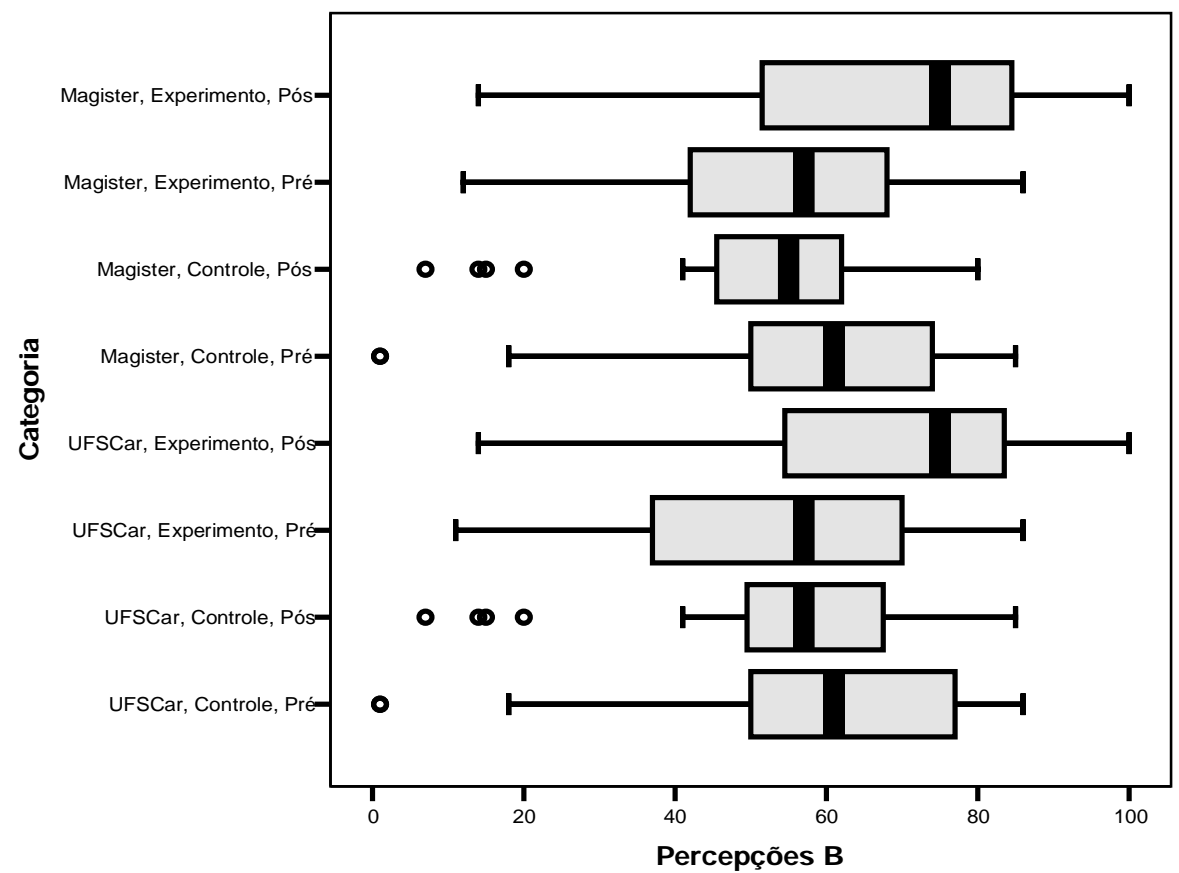

2AK - Percepções C: Qual sua emoção ao entrar em uma mata?

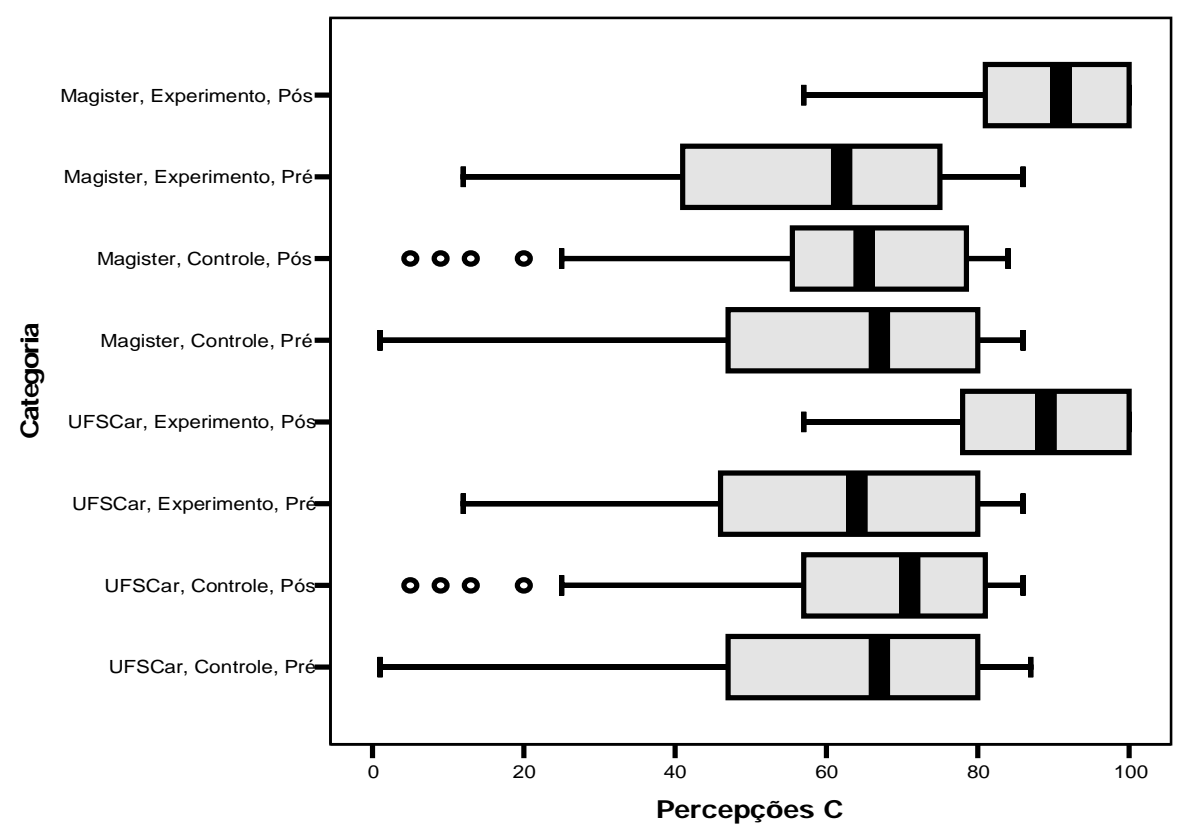




\section{AL - Percepções D: O que você sente sobre a caça e a venda de animais silvestres?}

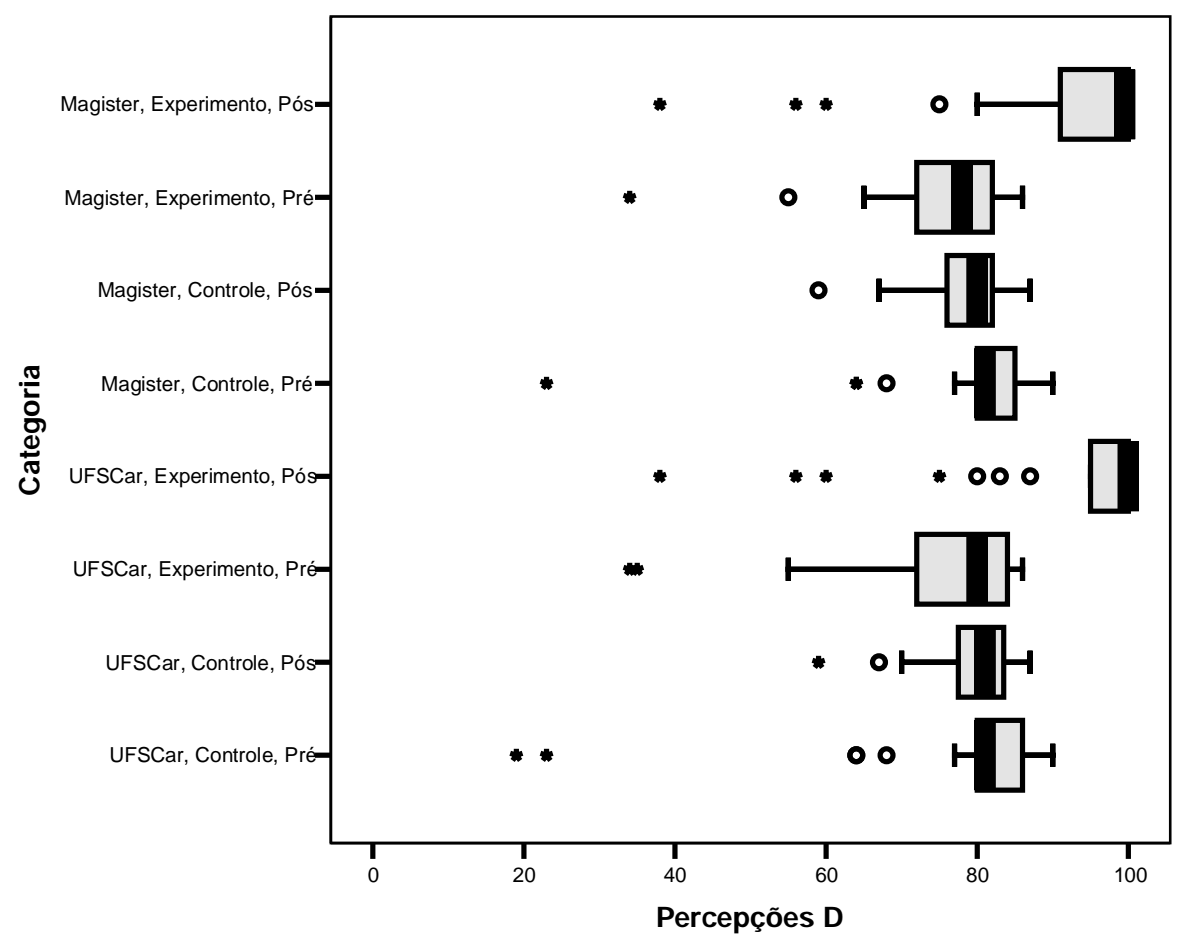




\section{AM - Percepções E: O que você sente quando vê áreas de mata queimando?}

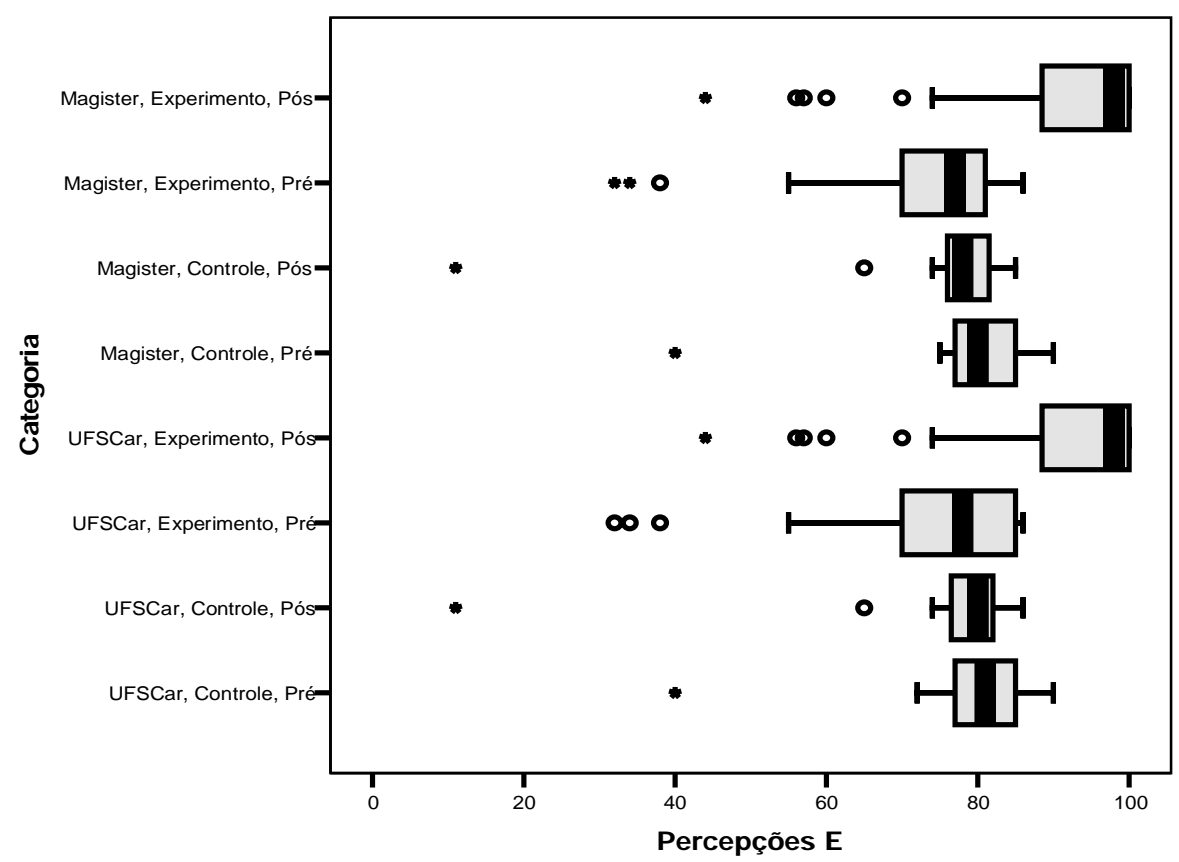


2AN - Percepções F: Você concorda com a afirmação “Garantir a preservação de uma espécie é garantir a preservação da mata"

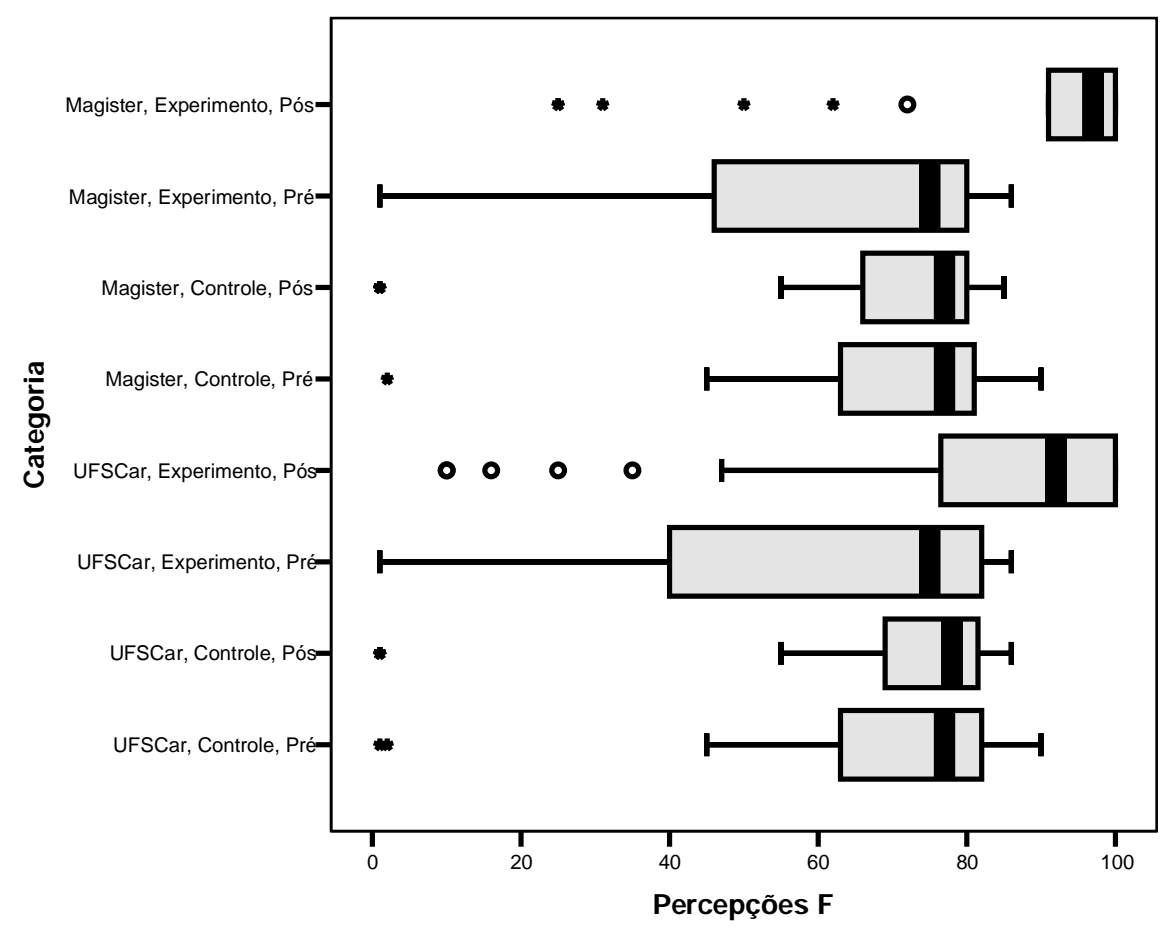




\section{AO - Percepções G: O que você sente ao entrar numa caverna de calcário?}

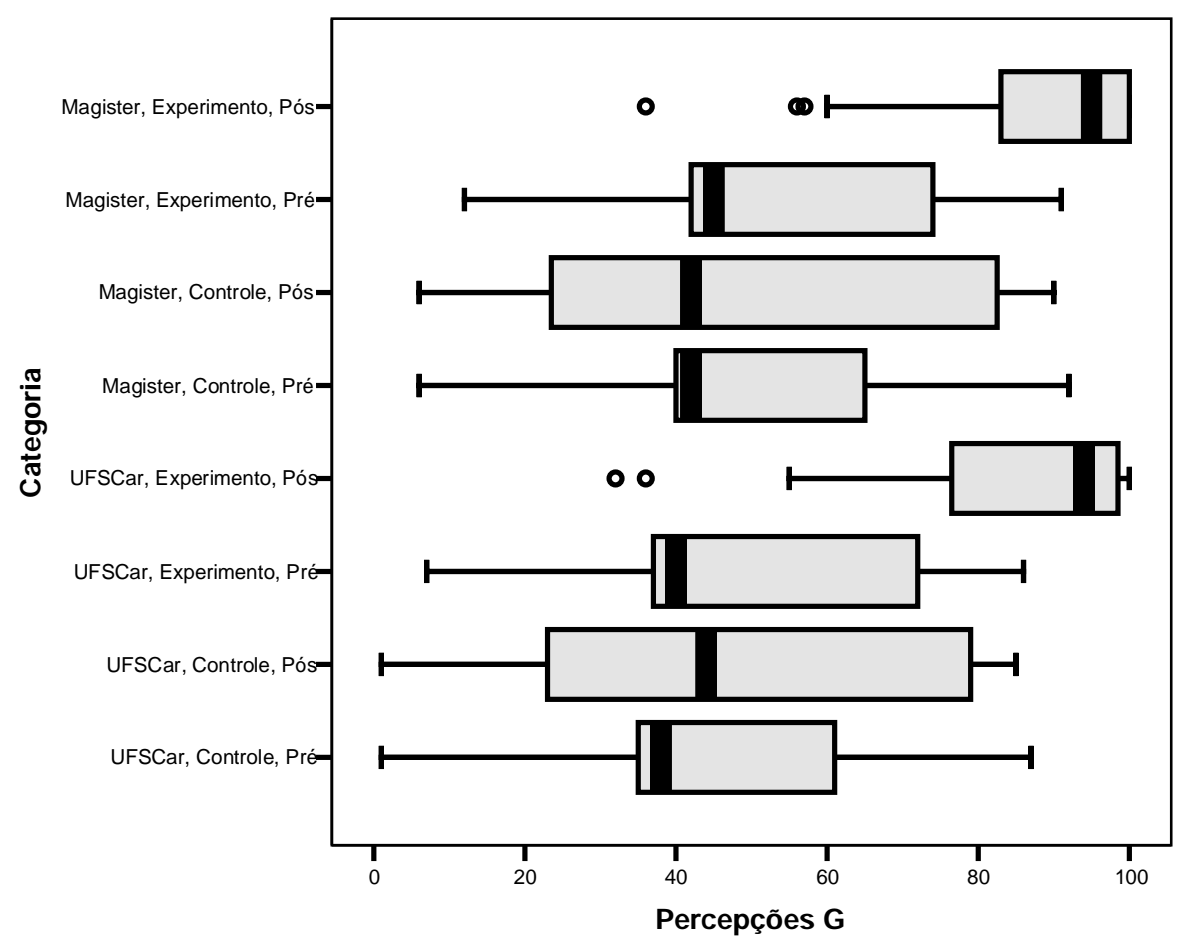




\section{AP - Percepções H: Você concorda com a afirmação “o modo de vida das populações tradicionais deve ser mantido"?}

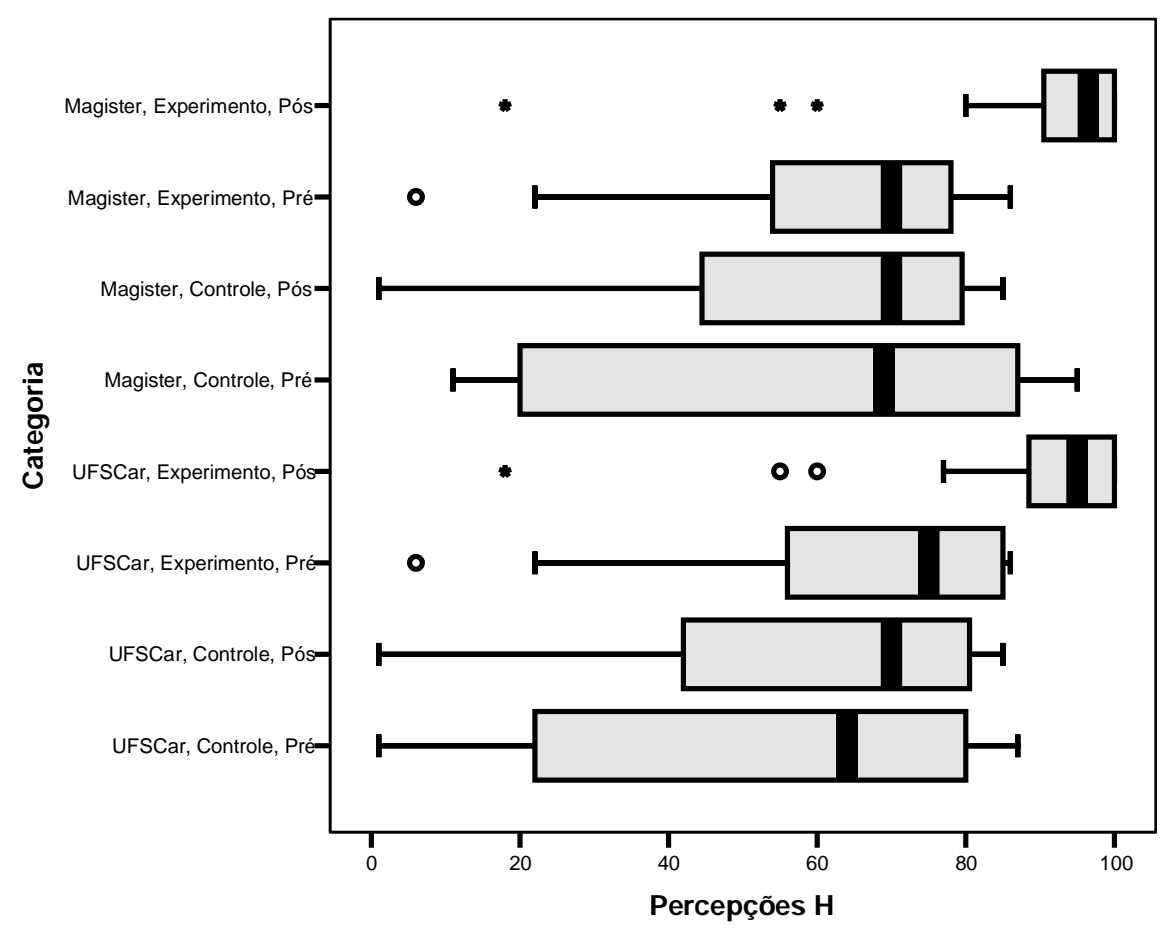




\section{AQ - Percepções I: O que você sente ao visitar áreas} naturais?

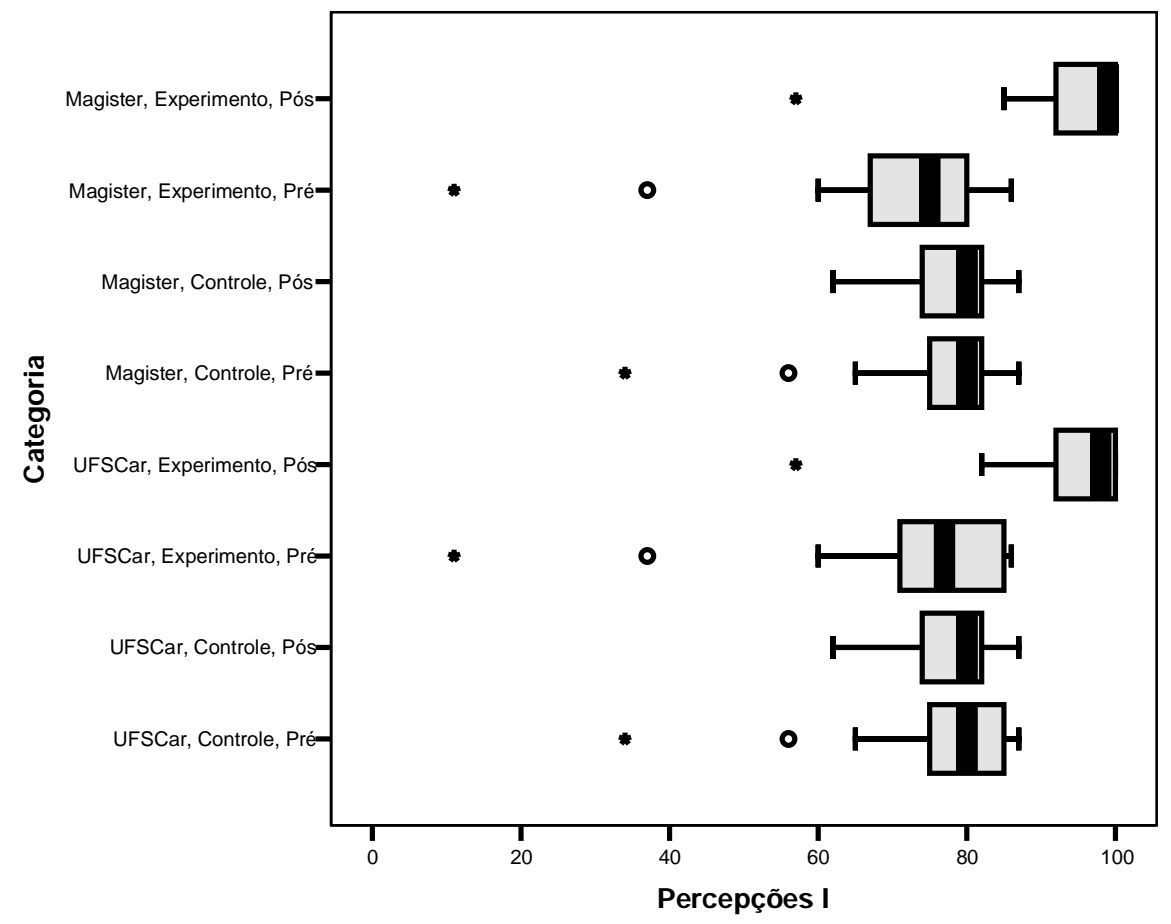


2AR - Percepções J : Você concorda com a afirmação “a preservação da Mata Atlântica é urgente"?

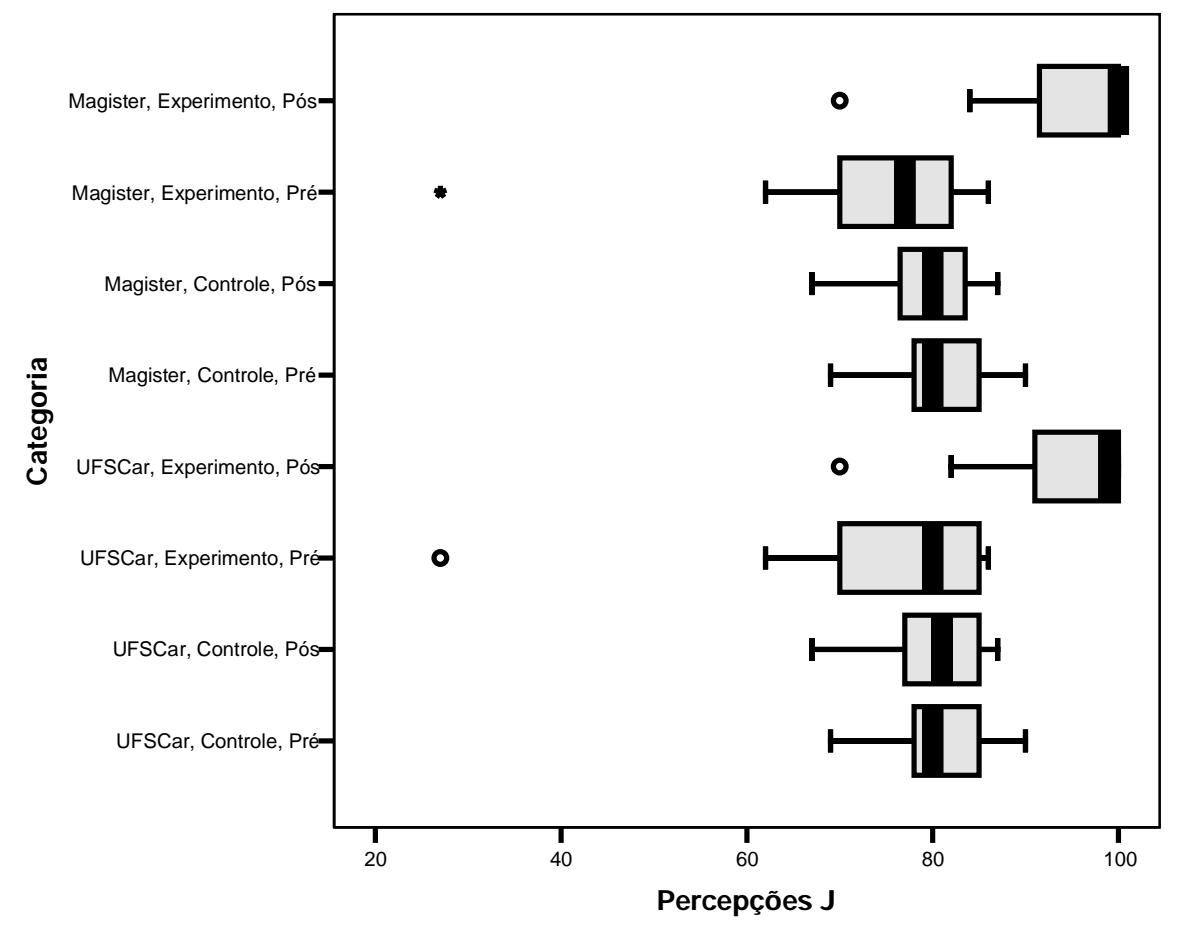

2AS - Percepções K: O que você sente quando está em

contato direto com a Natureza?

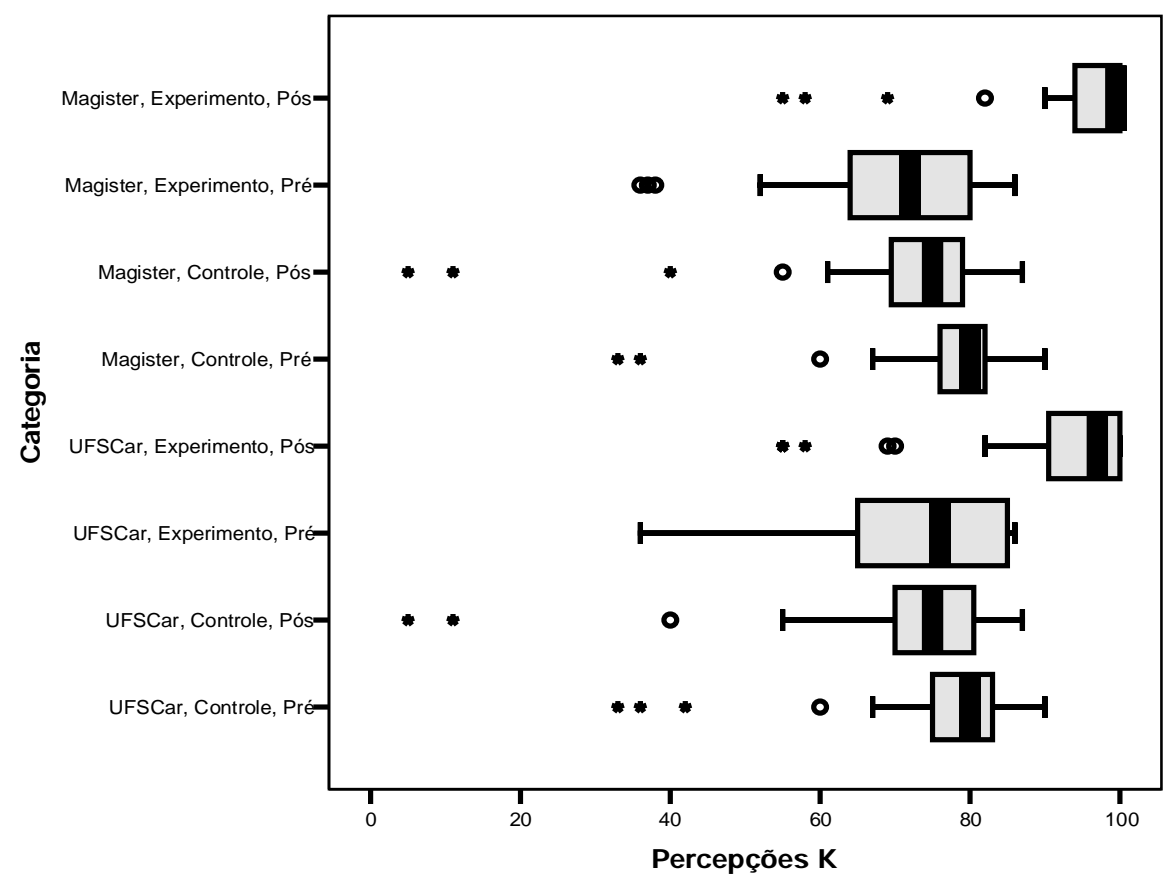




\section{AT - Percepções L: Você concorda com a afirmação “a natureza ensina ao ser humano como ele deve viver"?}

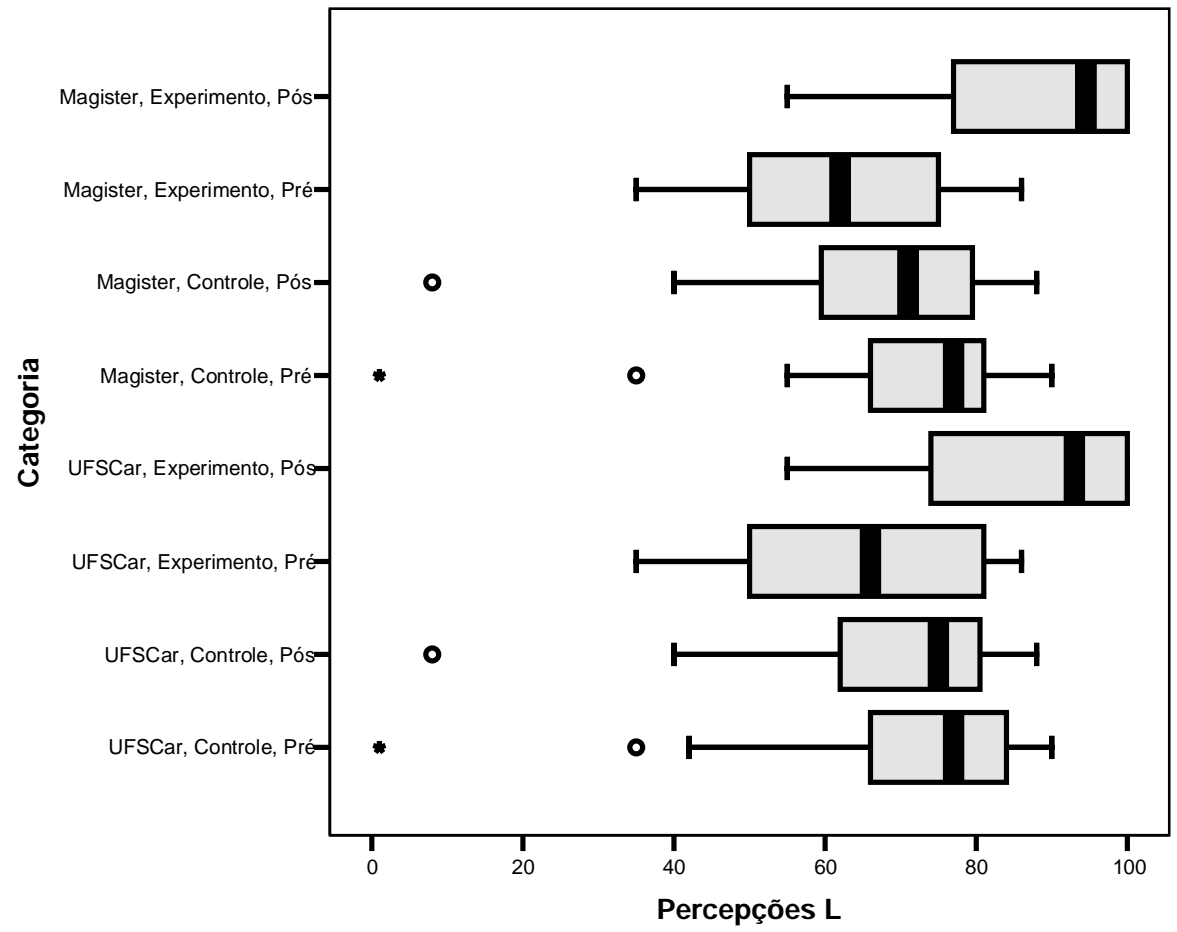


2AU - Percepções M: Você concorda com a afirmação “os ambientalistas são pessoas que deveriam pensar mais no desenvolvimento da sociedade"?

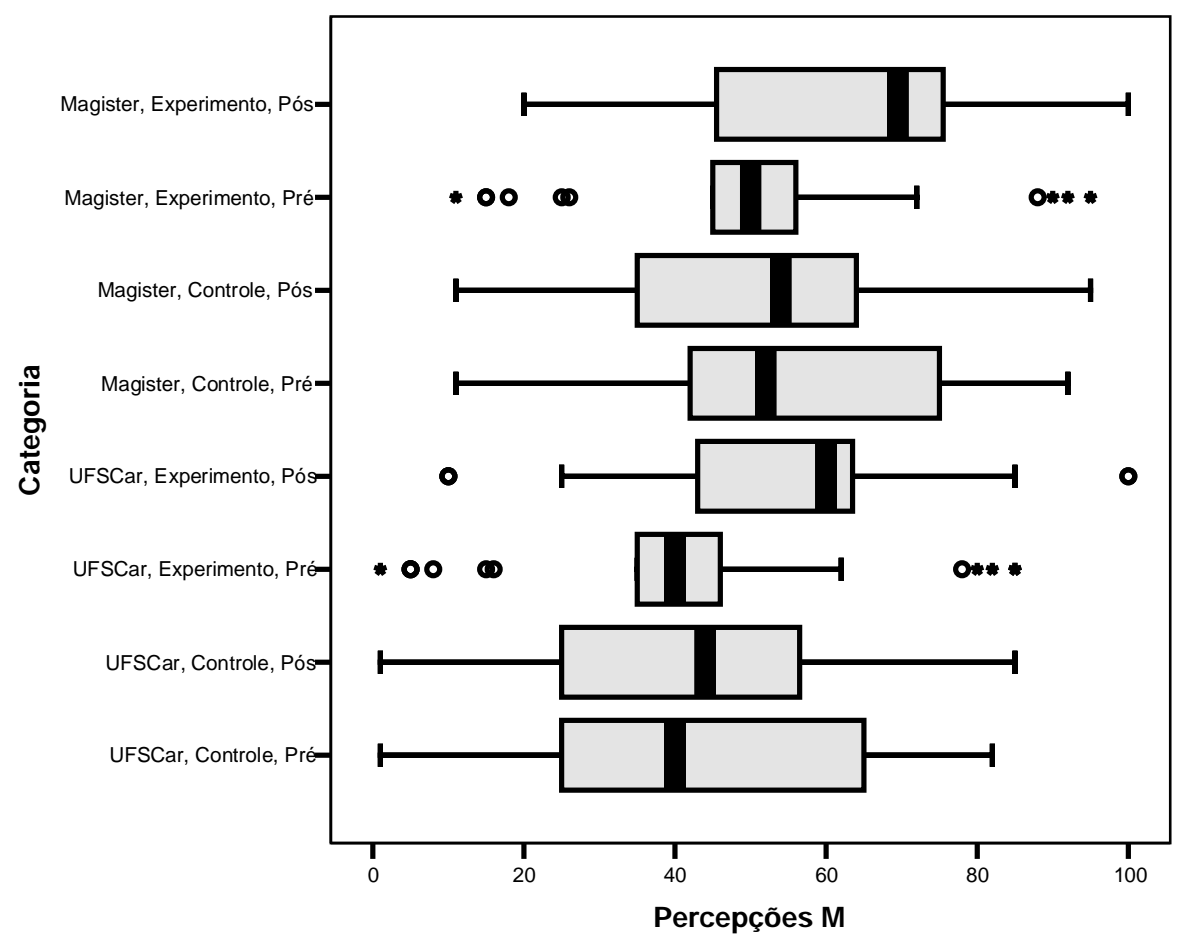


2AV - Afirmações Paradigmas A: A característica decisiva da economia deve ser a rejeição da busca de crescimento. $O$ produto nacional bruto deve ser reconhecido como um indicador em bancarrota. No lugar do PIB, as mudanças econômicas e sociais, tanto quanto as tecnológicas, devem ser medidas por sua contribuição à sustentabilidade.

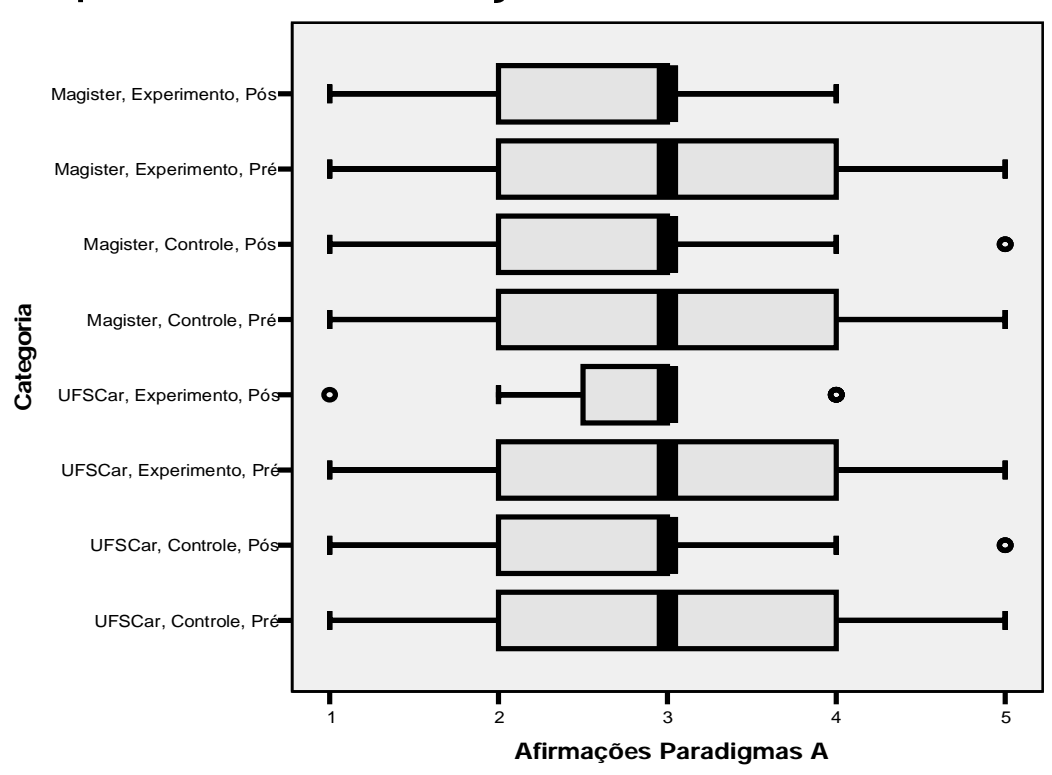


2AW - Afirmações Paradigmas B: As sociedades sustentáveis devem ter populações estáveis, como as que têm hoje em dia 13 países europeus e o Japão. A população mundial deve se estabilizar no máximo em oito bilhões de pessoas

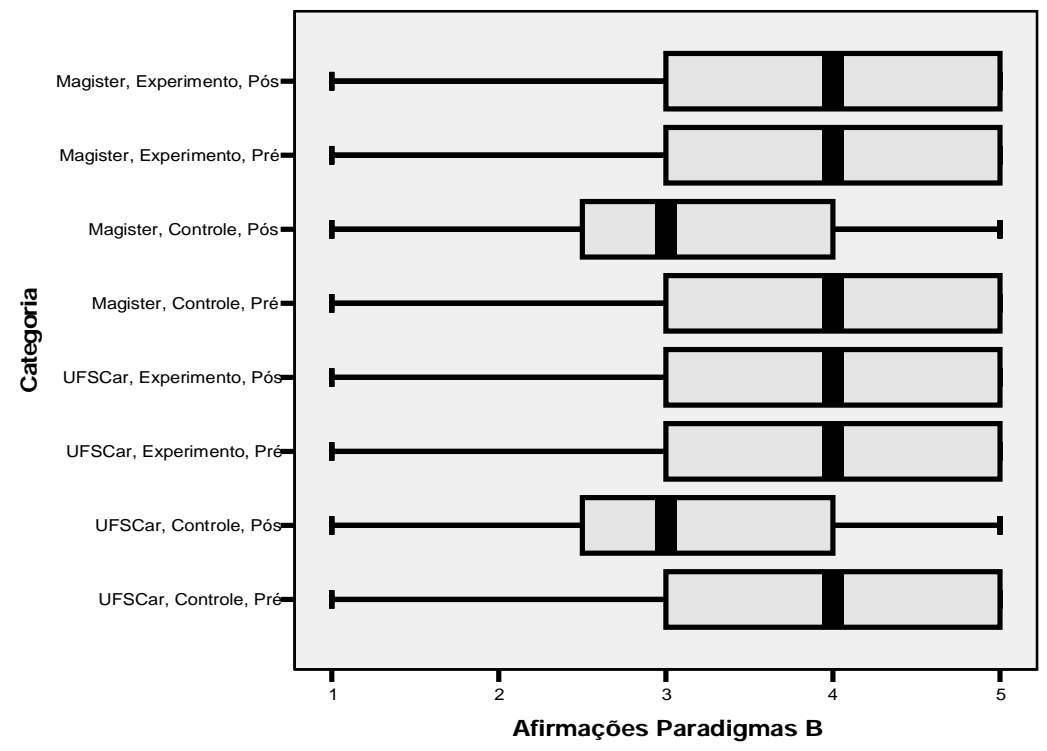


2AX - Afirmações Paradigmas C: Nas indústrias, a reciclagem deve ser a única fonte de matéria prima. $O$ desenho industrial deve se concentrar na durabilidade e uso reiterado, em vez da vida curta e descartável dos produtos. O uso de embalagens descartáveis deve ser eliminado

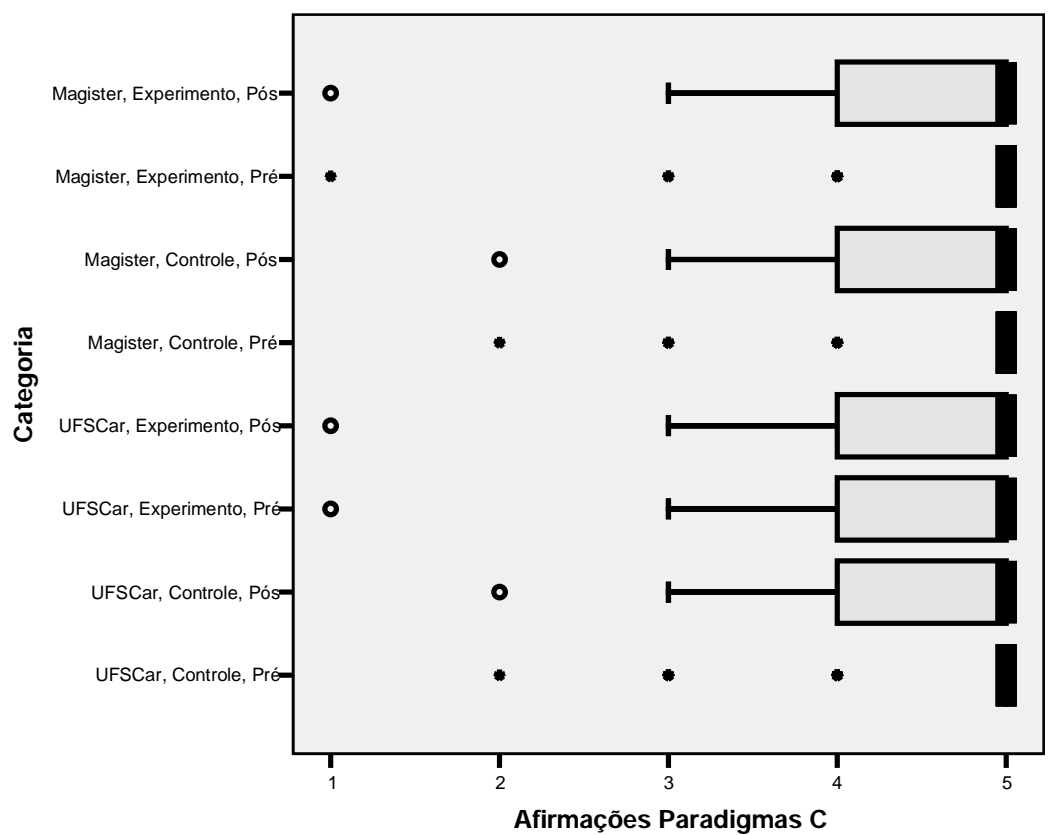


2AY - Afirmações Paradigmas D: Os bosques tropicais devem ser integralmente conservados. Não deve haver desmatamento para obtenção de madeira e outros produtos. Pelo contrário, milhões de hectares de novas árvores devem ser plantados

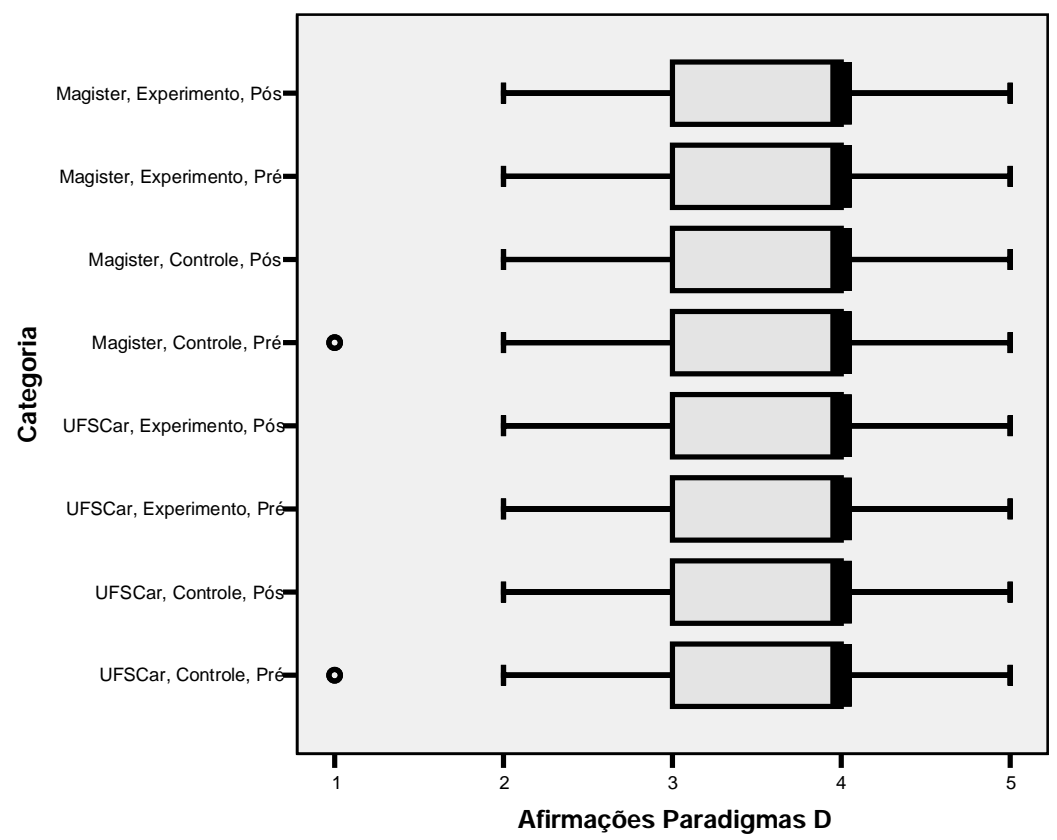


2AZ - Afirmações Paradigmas E: O uso exaustivo de pastagens deve ser eliminado, assim como deve haver modificação na cadeia alimentar das sociedades humanas, para incluir menos carne e mais grãos e vegetais

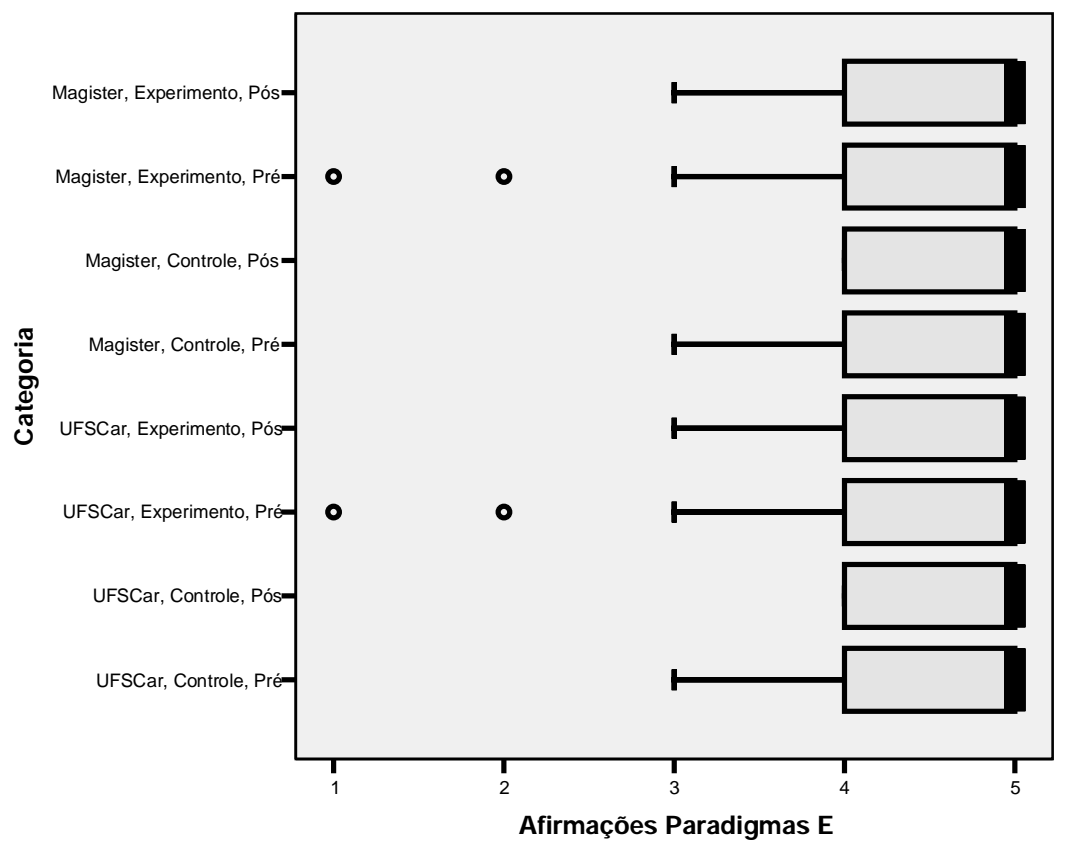

2BA - Afirmações Paradigmas F: A terra é como uma nave espacial com somente poucos e limitados recursos que não podem ser facilmente repostos. $O$ equilíbrio da natureza é muito delicado, alterado facilmente, e de difícil recuperação

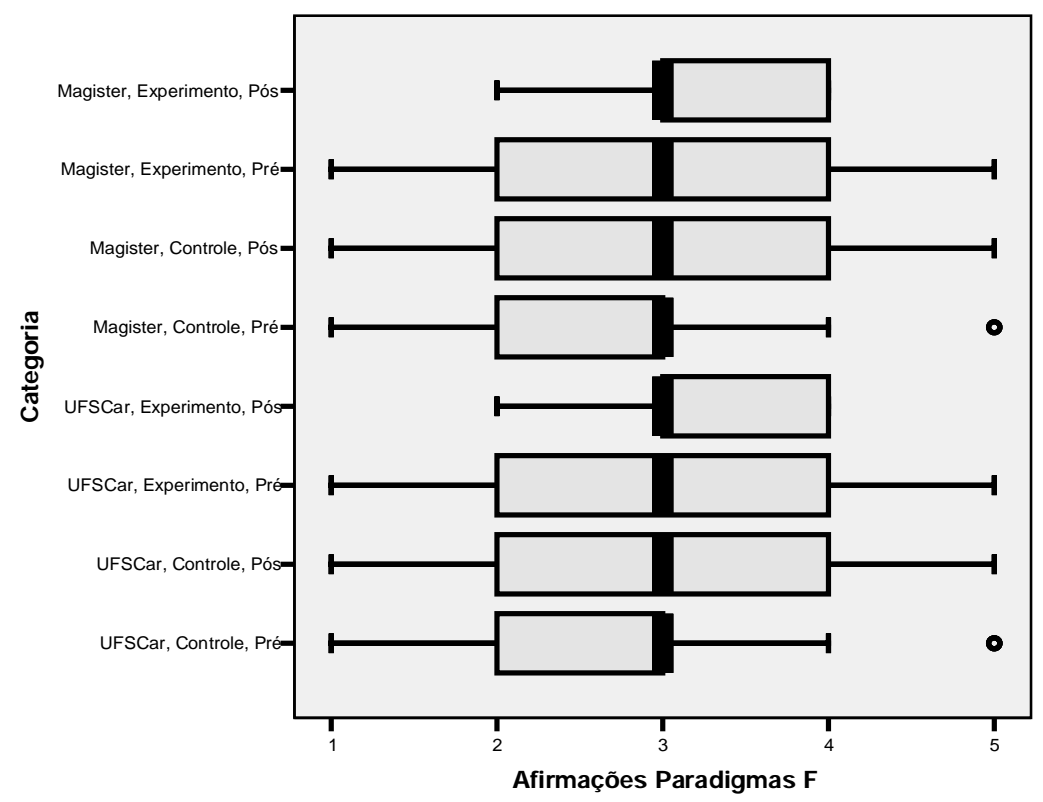


2BB - Afirmações Paradigmas G: Quando os seres humanos interferem com a natureza ela produz, freqüentemente, conseqüências desastrosas.Os seres humanos devem viver na harmonia com natureza a fim sobreviver, em sociedades que simplifiquem suas bases tecnológicas e consumam apenas o mínimo possível para garantir a qualidade de vida

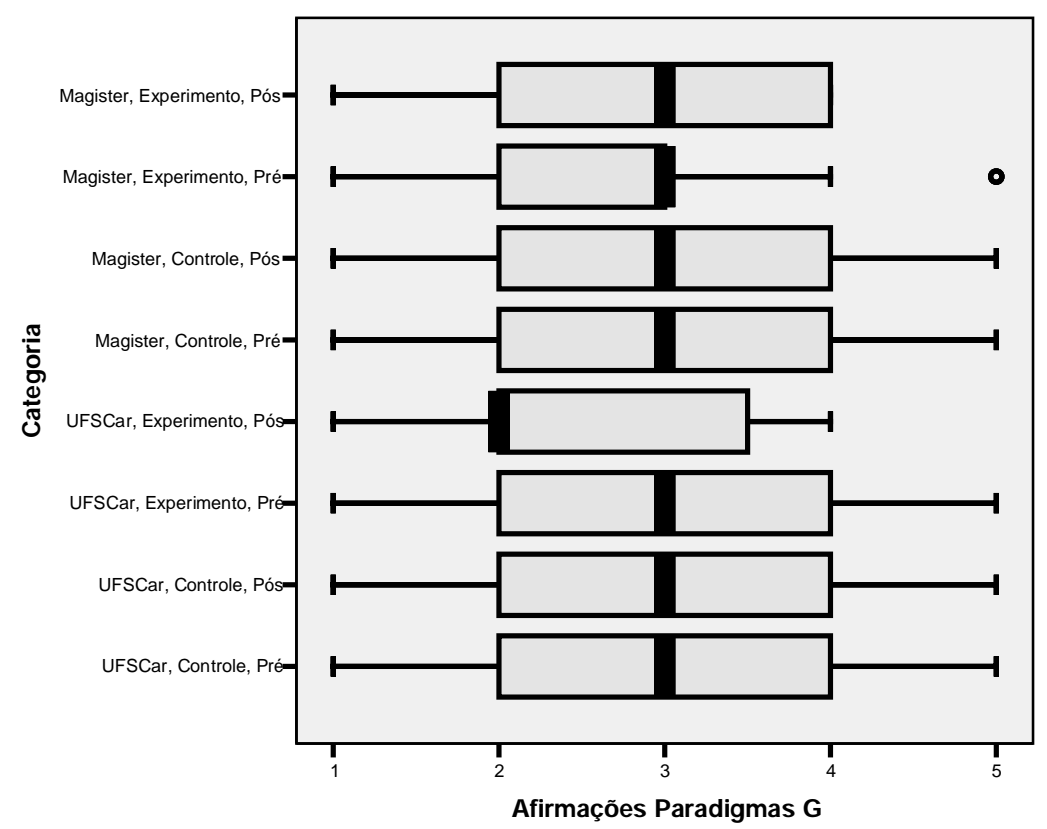

2BC - Afirmações Paradigmas H: A educação ambiental deve envolver uma perspectiva holística, enfocando a relação entre o ser humano, a natureza e o universo de forma interdisciplinar

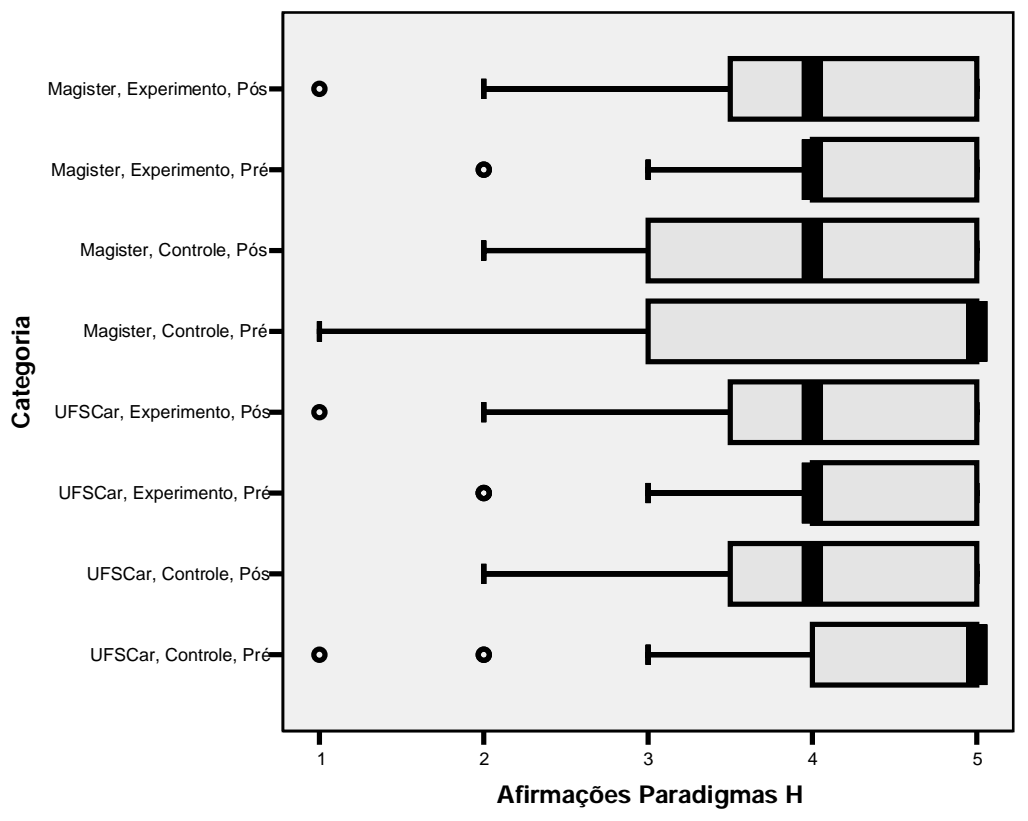


2BD - Afirmações Paradigmas I: É preciso garantir a satisfação das necessidades básicas da população (educação, alimentação, saúde, lazer, etc), elaborando-se um sistema social que garanta emprego, segurança social e respeito a outras culturas (erradicação da miséria, do precon-ceito e do massacre de populações oprimidas, como os índios)

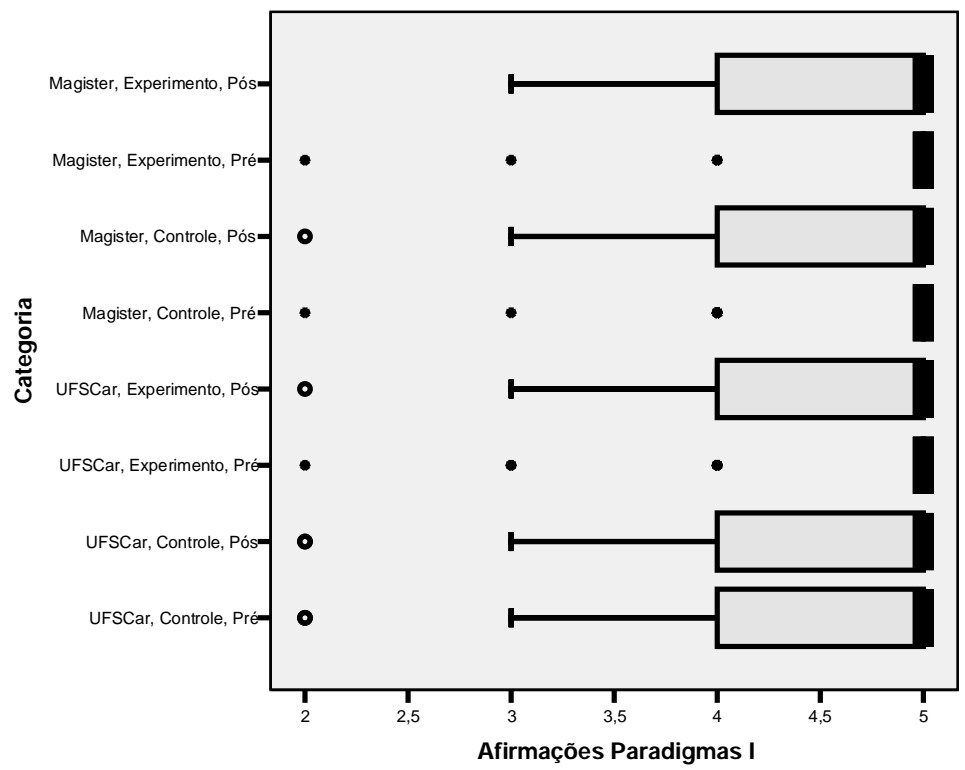

2BE - Afirmações Paradigmas J : É preciso que haja solidariedade para com as gerações futuras (preservar o ambiente de modo que elas tenham chance de viver), limitando o crescimento populacional, garantindo alimentação em longo prazo, reservando a biodiversidade e os ecossistemas, diminuindo o consumo de energia e desenvolvendo tecnologias que admitem o uso de fontes energéticas renováveis, aumentando a produção Kndustrial nos países não-industrializados à base de tecnologias ecologicamente adaptadas, controle da urbanização selvagem e integração entre campo e cidades menores; e despoluindo rios e outros ambientes 


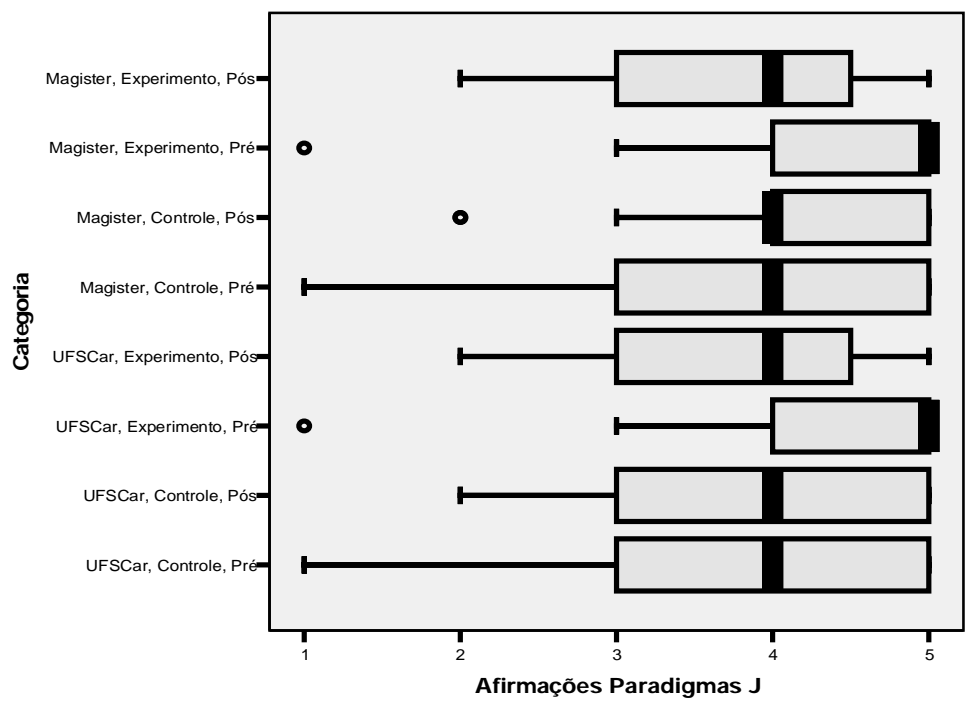

2BF - Afirmações Paradigmas K: As organizações do desenvolvimento devem adotar a estratégia de desenvolvimento sustentável. Os seres humanos têm o direito de modificar o ambiente natural, desde que o façam de modo a garantir a recuperação natural dos recursos utilizados

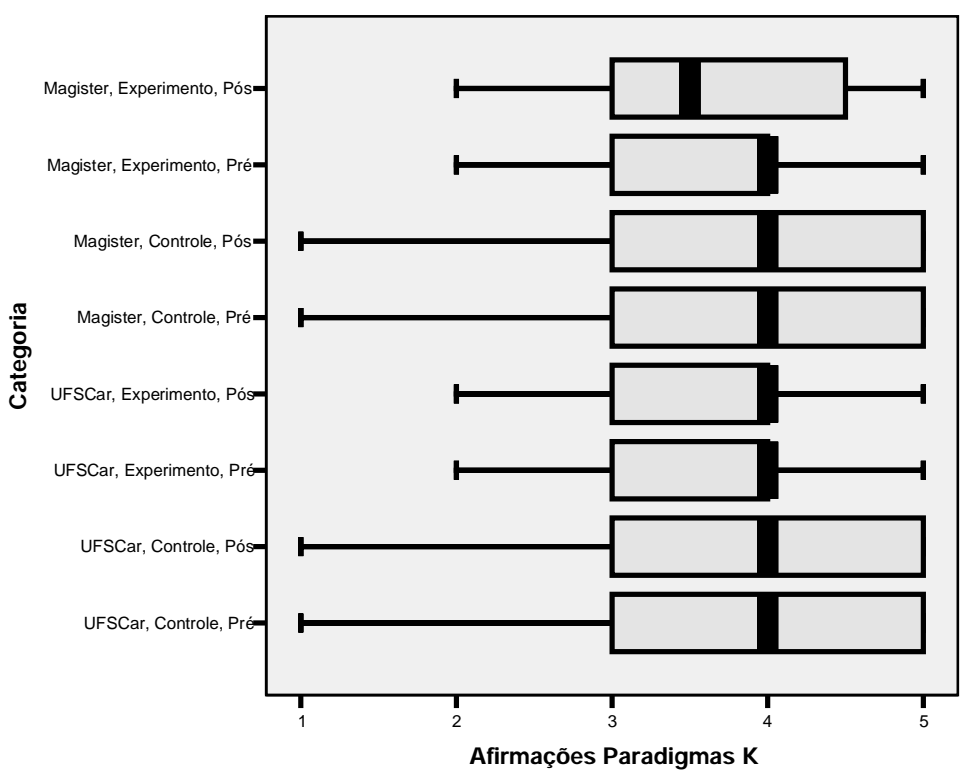


2BG - Afirmações Paradigmas L: Para manter uma economia saudável nós teremos que desenvolver "uma economia sustentável" onde o crescimento industrial seja controlado, mas que continue gerando riquezas e bens que possam auxiliar na solução dos graves problemas ambientais

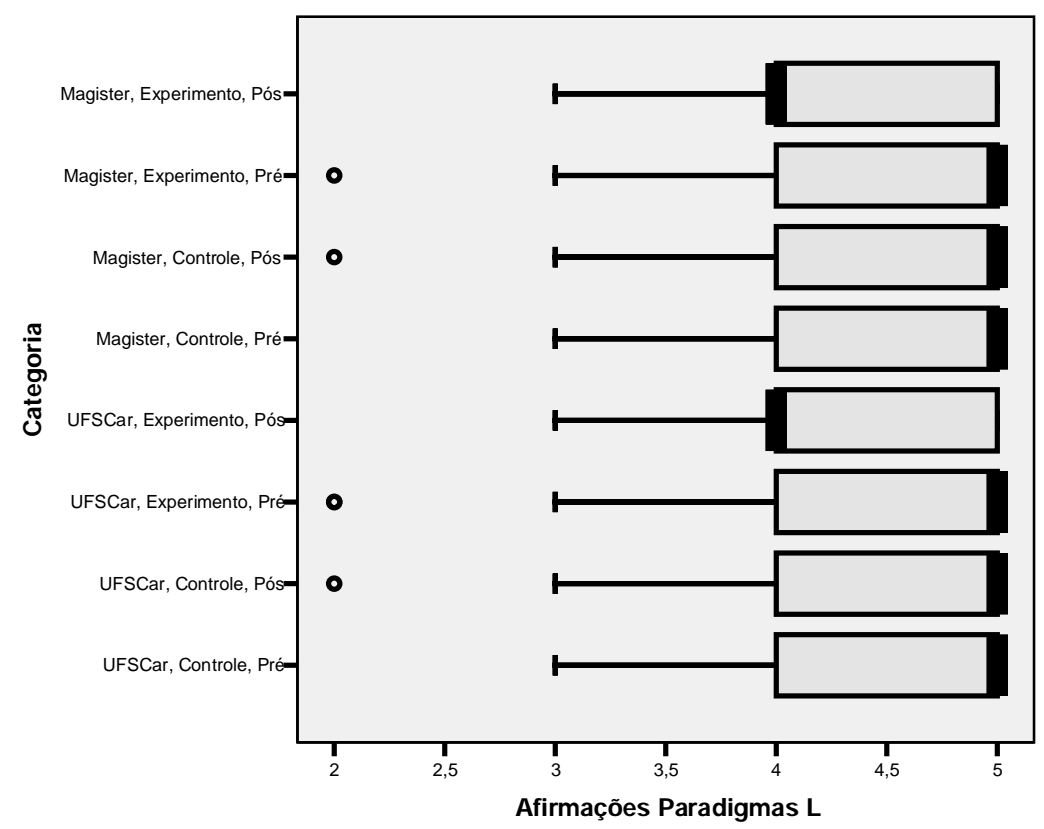

2BH - Afirmações Paradigmas M: Os seres humanos não necessitam adaptar-se ao ambiente natural porque podem manejá-lo de modo a servir as suas necessidades, usando para isso, de modo racional, todo avanço científico e tecnológico disponível

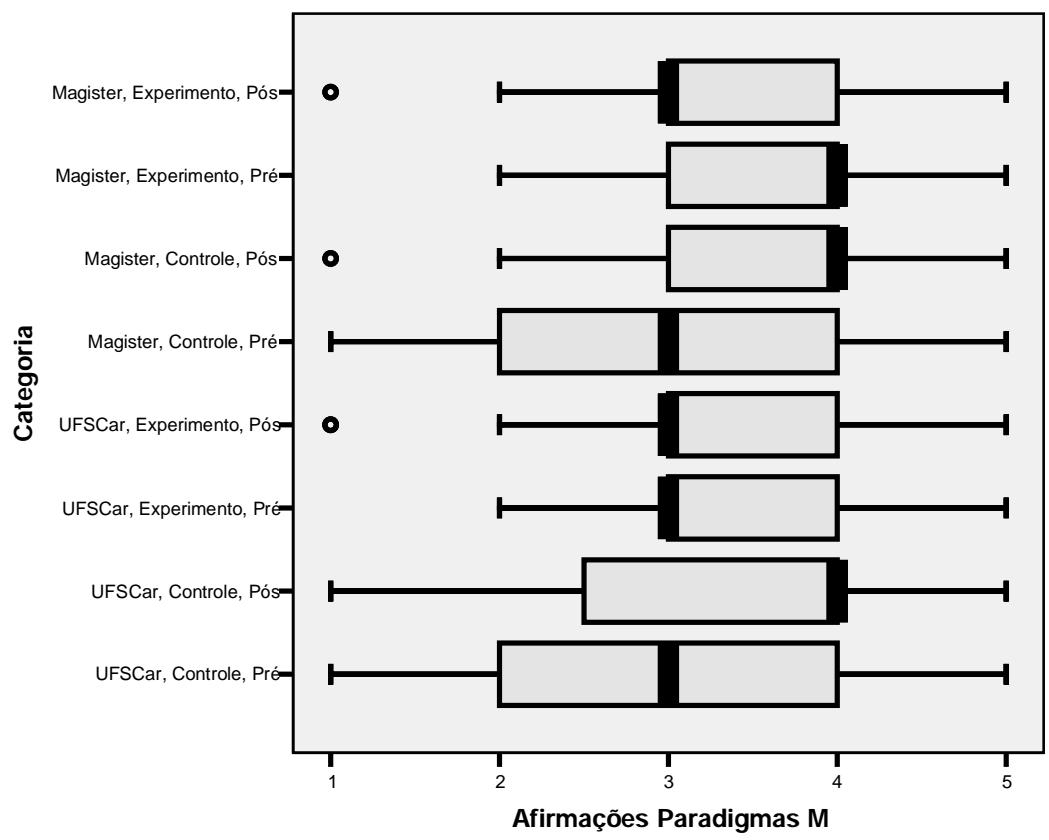


2BI - Afirmações Paradigmas N: Para o uso da madeira, é necessário que se faça o manejo sustentável das florestas, plantando-se novas árvores a cada uma que é derrubada

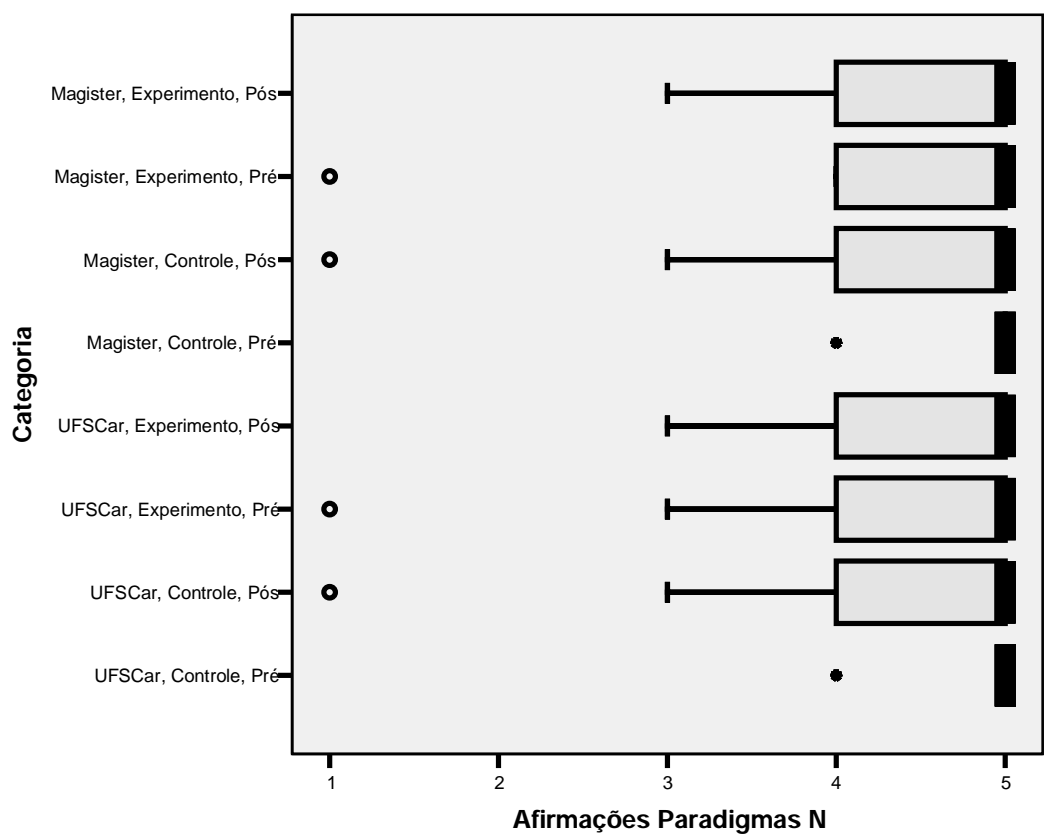

2BJ - Afirmações Paradigmas O: No futuro, será possível otimizar o sistema de transporte. As pessoas devem se movimentar mediante sistemas altamente desenvolvidos de ônibus e transportes sobre trilhos

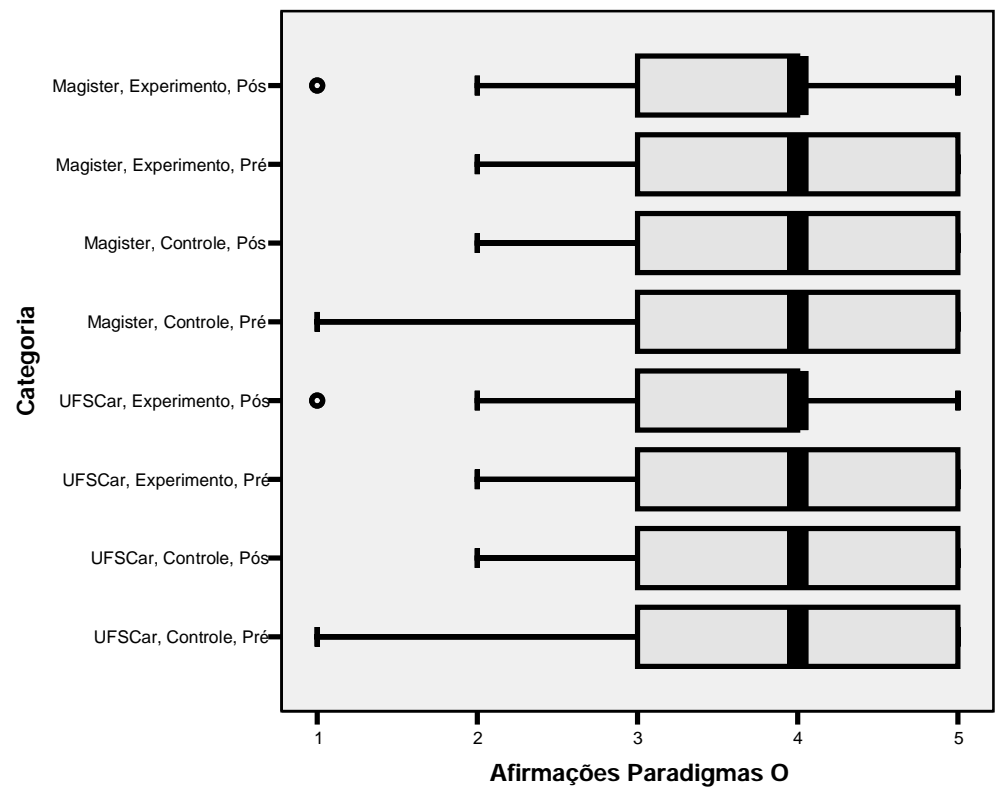


2BK - Afirmações Paradigmas P: As empresas de reciclagem devem ocupar o lugar das atuais companhias de limpeza urbana e disposição final do lixo, todos os materiais descartáveis devem ser coletados de modo a alimentar a indústria com matéria prima novamente utilizável

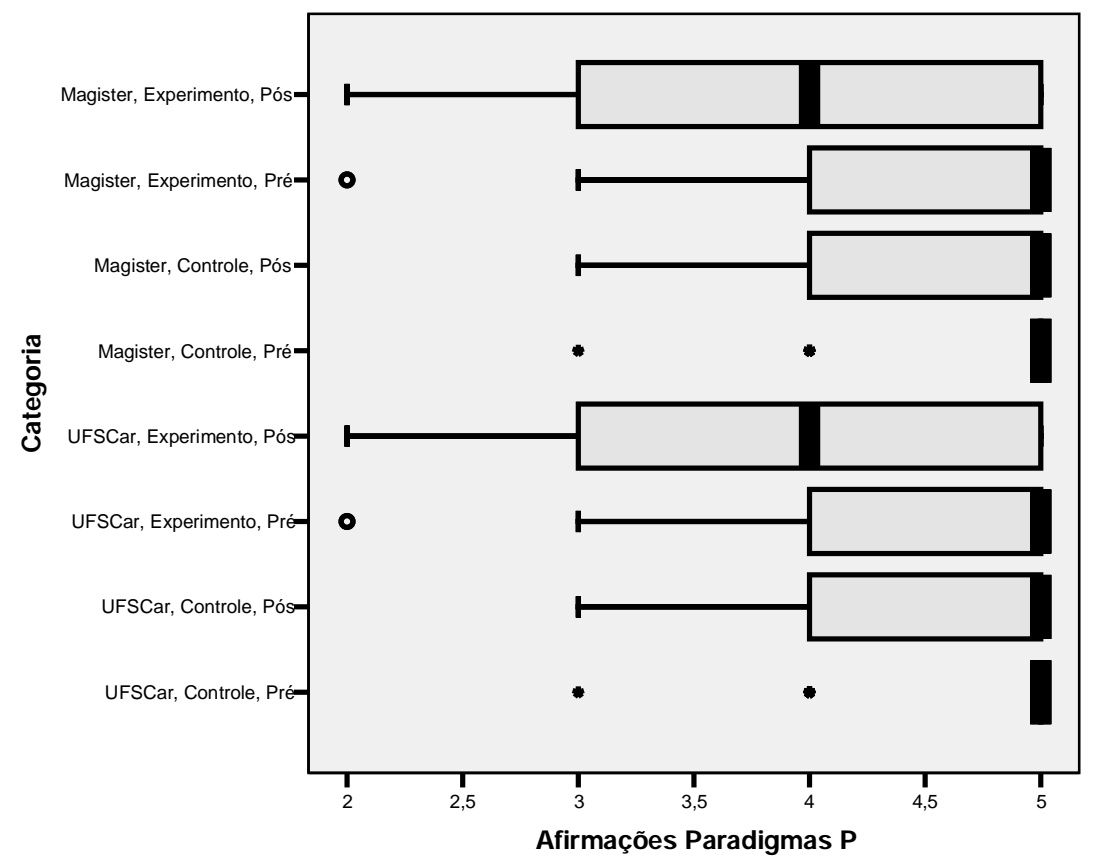




\section{ANEXO 3 - GRÁFICOS QUE REPRESENTAM A MÉDIA MAIS OU MENOS DUAS VEZES O ERRO PADRÃO DA MÉDIA - ESTUDOS 3a E 3b}

Auto-avaliação do Conhecimento

\section{Grupo Magistério}

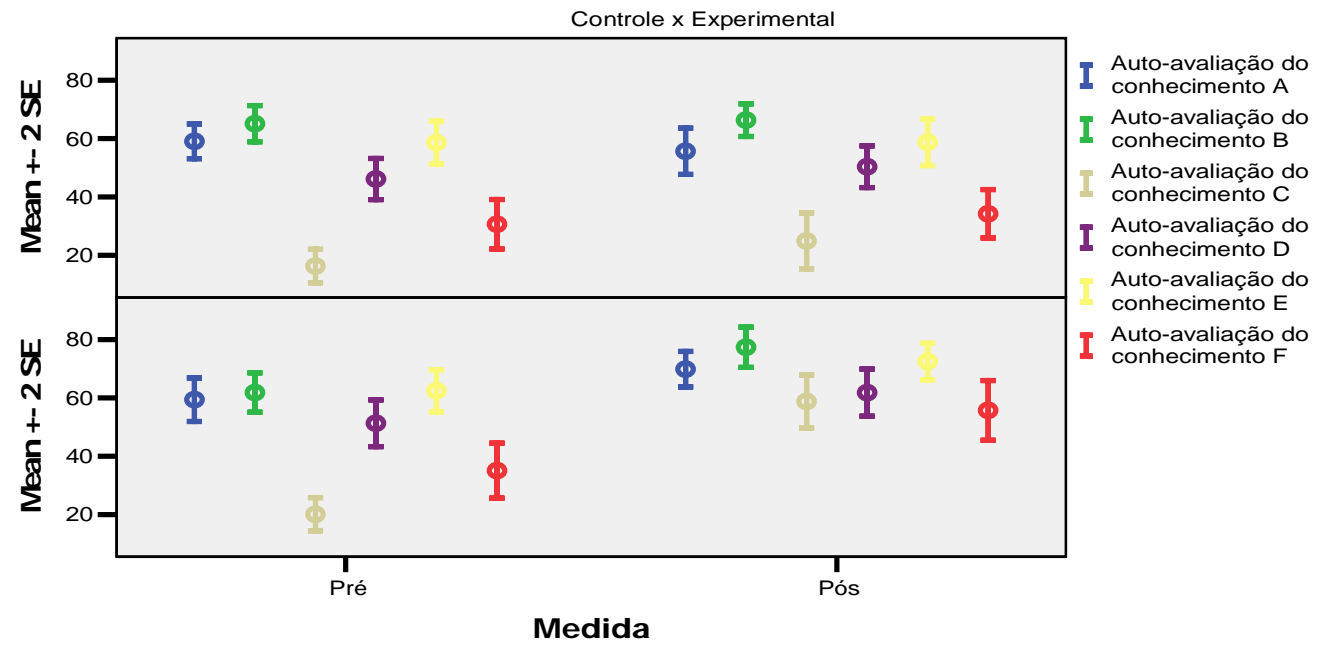

Sentimentos

\section{Grupo Magistério}

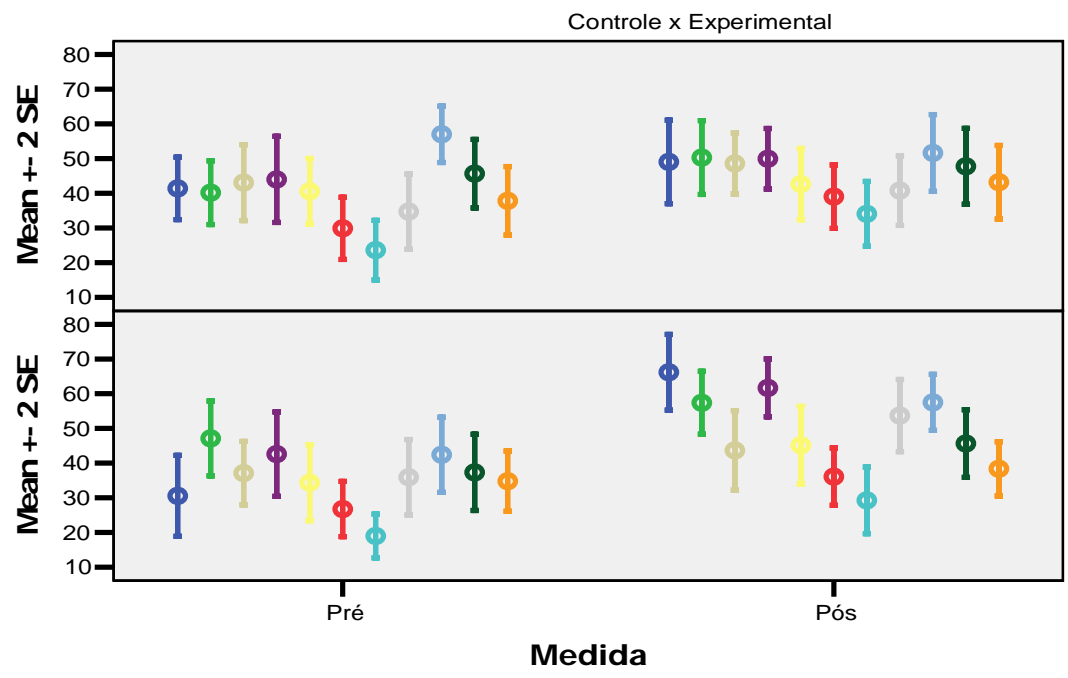

I Sentimentos A

I Sentimentos B

Sentimentos C

I Sentimentos D

Sentimentos E

I Sentimentos $F$

Sentimentos G

Sentimentos $\mathrm{H}$

- Sentimentos I

I Sentimentos $\mathrm{J}$

Sentimentos $\mathrm{K}$ 
Atitudes Pró-Ambiente

\section{Grupo Magistério}

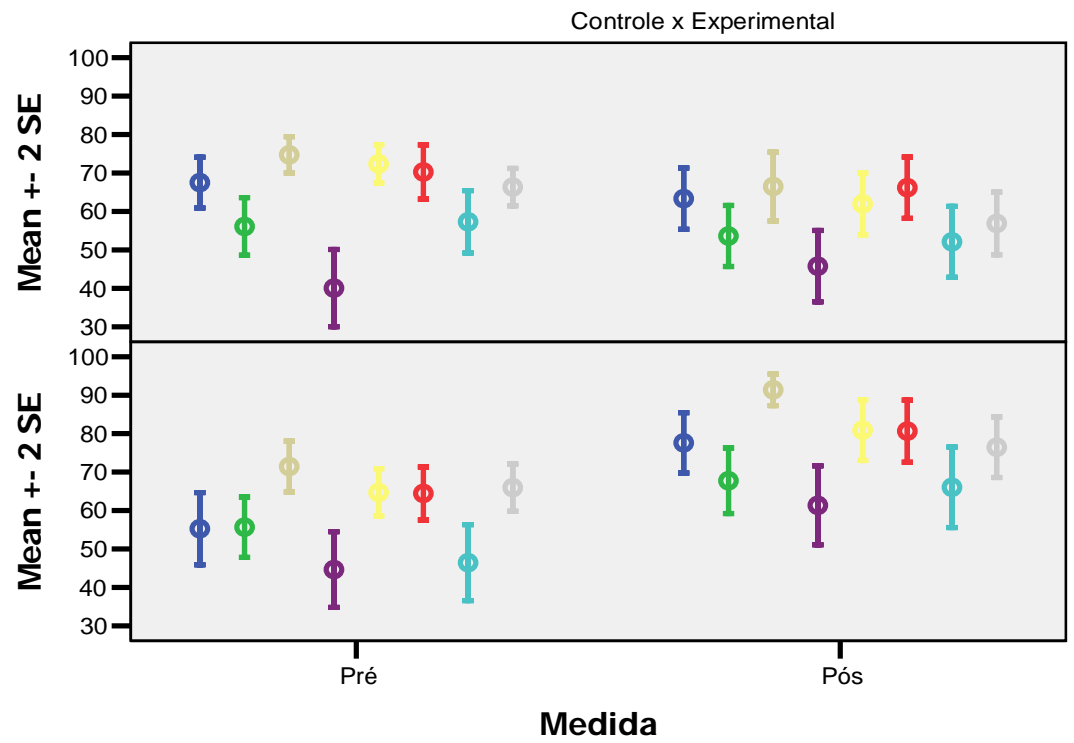

I Atitudes Pró-Ambiente A

I Atitudes Pró-Ambiente B

Atitudes Pró-Ambiente C

I Atitudes Pró-Ambiente D

Atitudes Pró-Ambiente $\mathrm{E}$

I Atitudes Pró-Ambiente $F$

I. Atitudes Pró-Ambiente $G$

Atitudes Pró-Ambiente $\mathrm{H}$

Atitudes Pró-Ambiente

\section{Grupo Magistério}

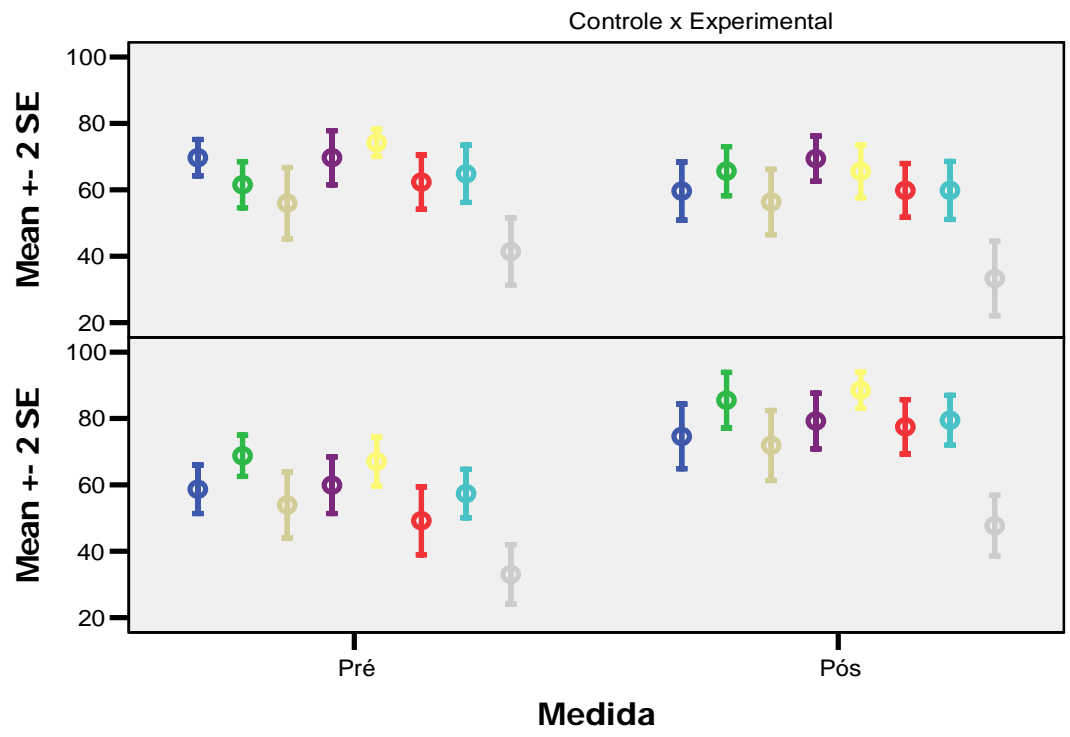

I Atitudes Pró-Ambiente I

I Atitudes Pró-Ambiente $\mathrm{J}$

Atitudes Pró-Ambiente $\mathrm{K}$

I Atitudes Pró-Ambiente $L$

Atitudes Pró-Ambiente $\mathrm{M}$

I Atitudes Pró-Ambiente $\mathrm{N}$

I Atitudes Pró-Ambiente $O$

Atitudes Pró-Ambiente P 


\section{Afirmações referentes aos Paradigmas}

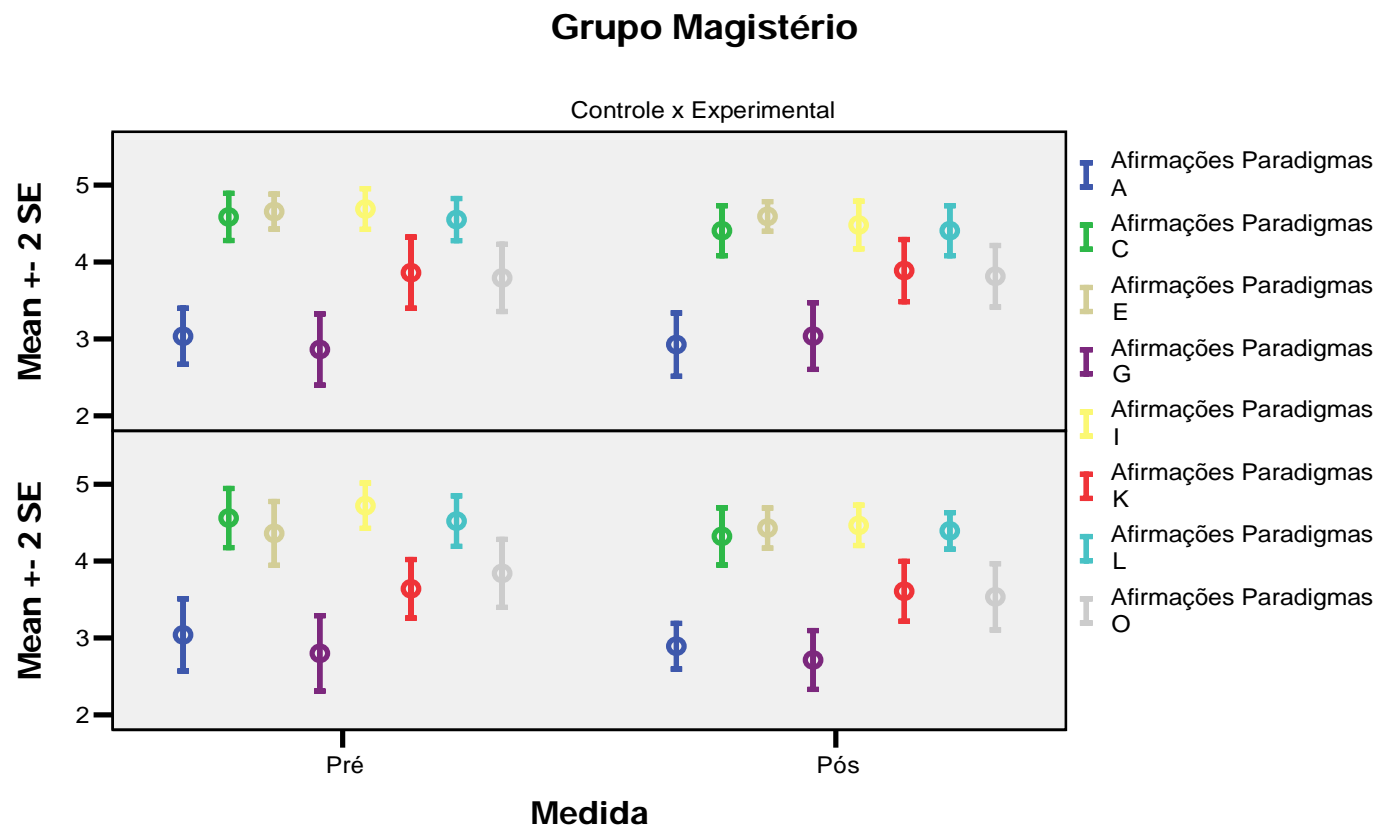

Afirmações referentes aos Paradigmas

\section{Grupo Magistério}

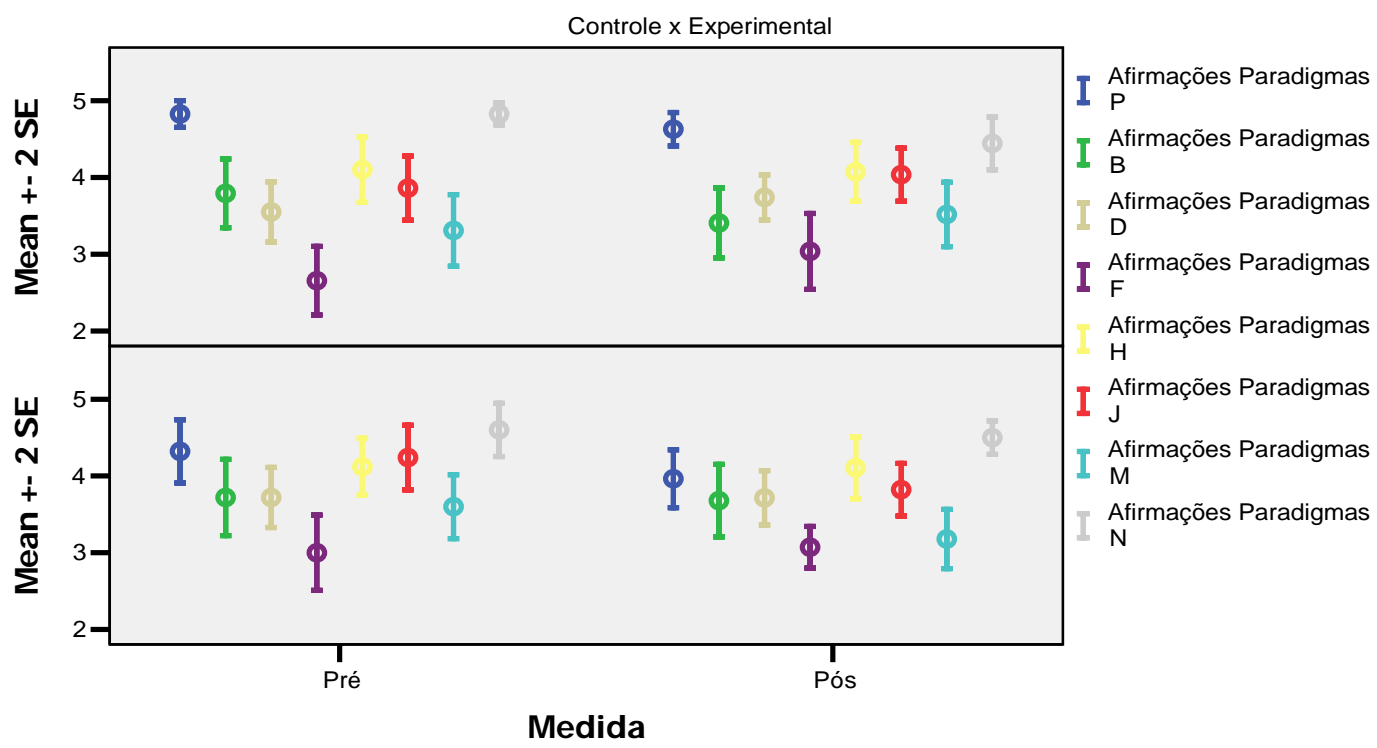




\section{Percepções}

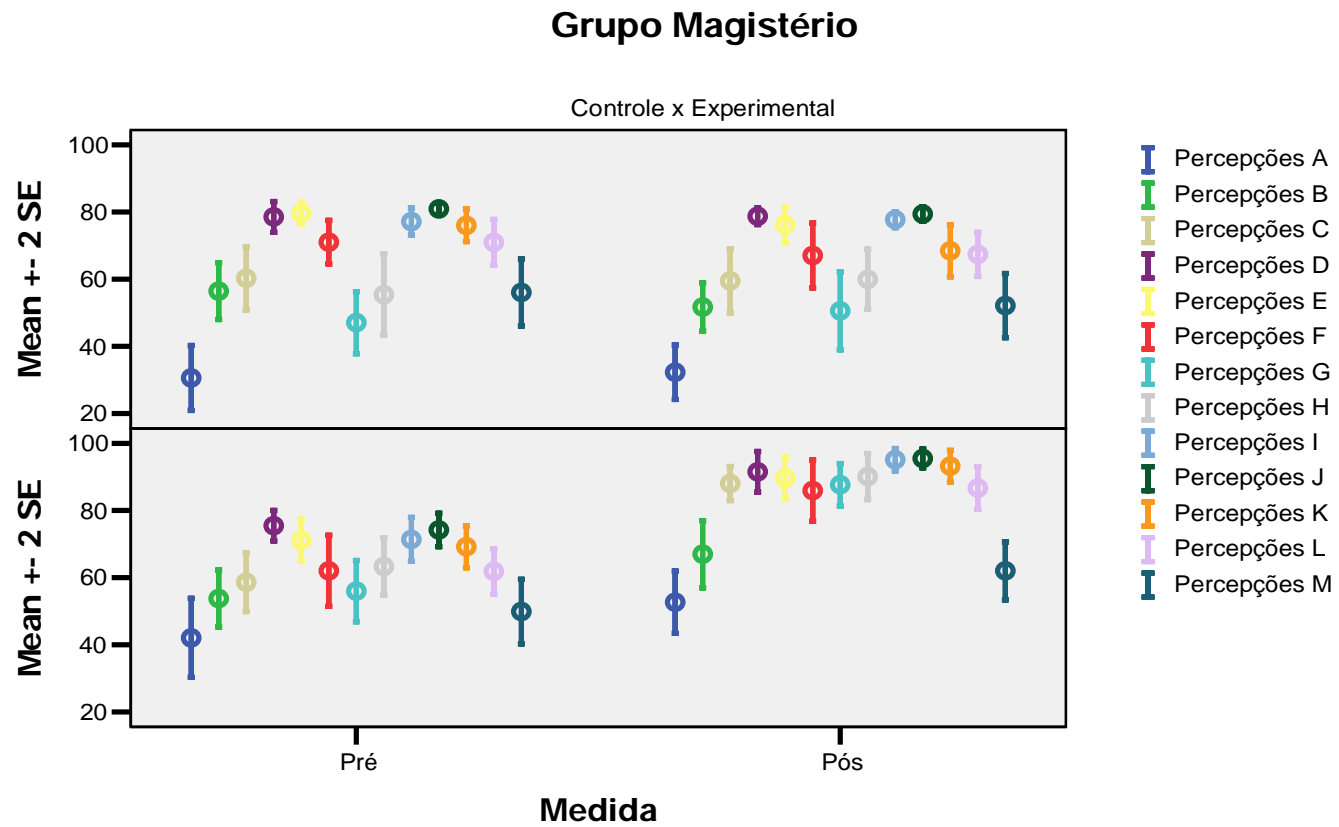

Auto-avaliação do Conhecimento

Grupo UFSCar

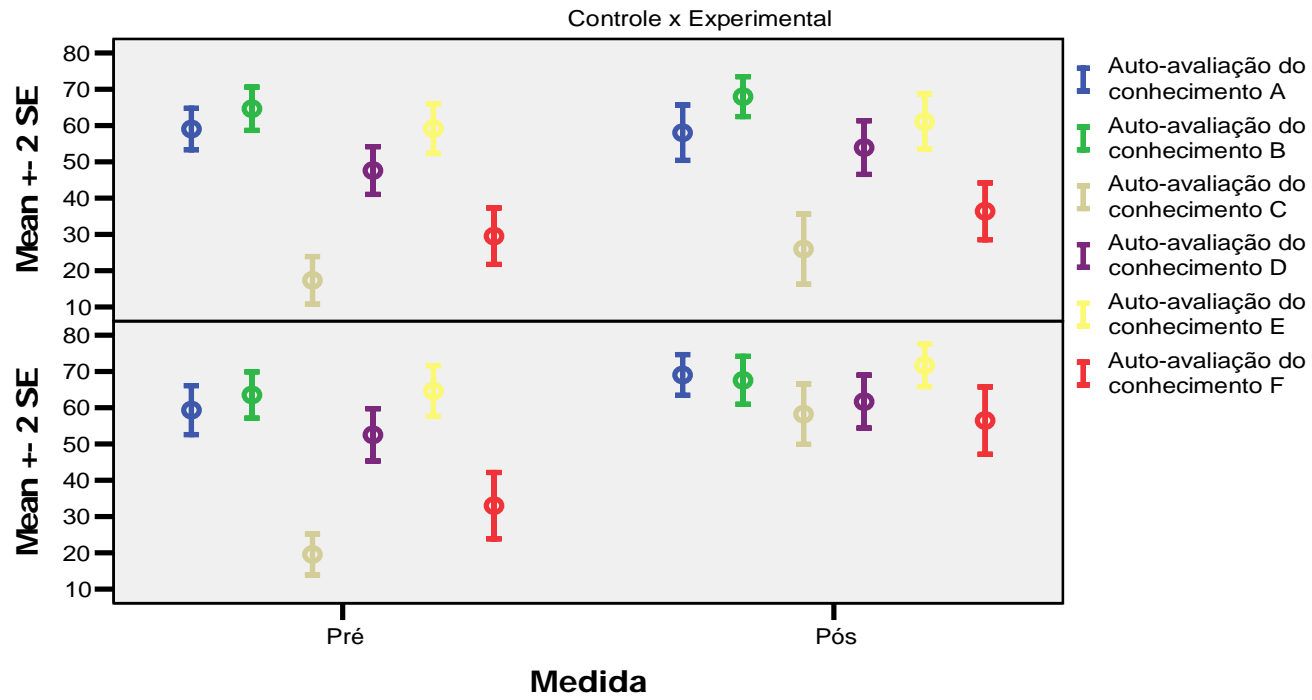




\section{Sentimentos}

\section{Grupo UFSCar}

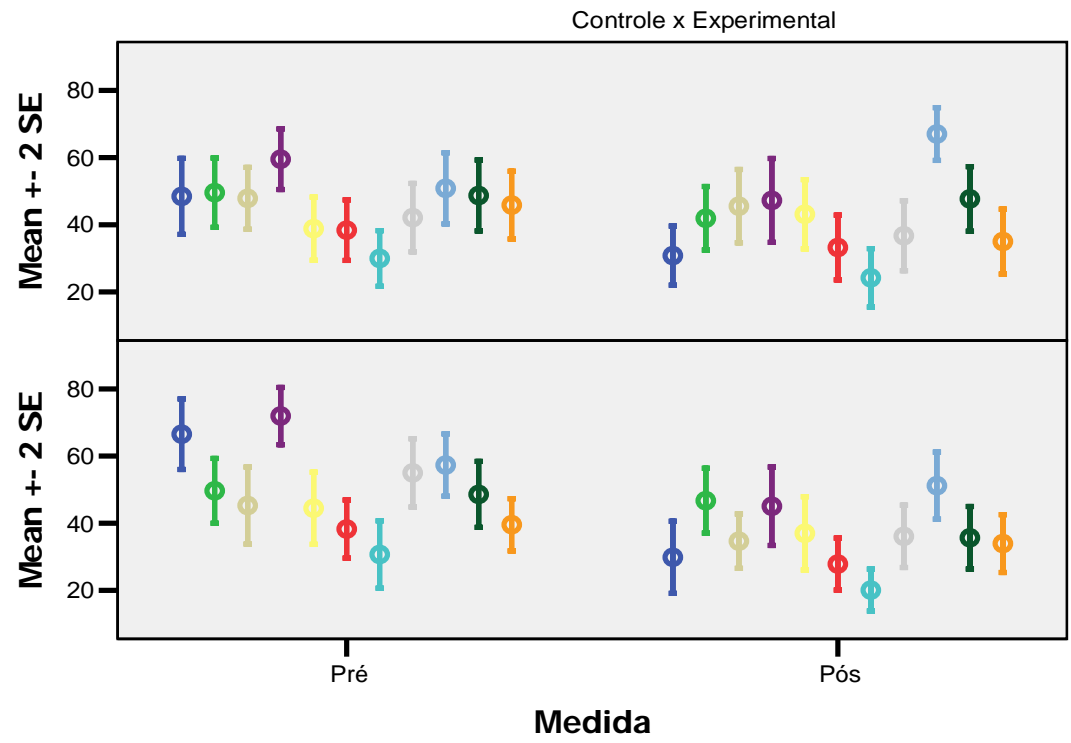

I Sentimentos A

I Sentimentos B

Sentimentos C

I Sentimentos D

Sentimentos E

I Sentimentos $\mathrm{F}$

I Sentimentos G

Sentimentos $\mathrm{H}$

I Sentimentos I

I Sentimentos $\mathrm{J}$

I Sentimentos $\mathrm{K}$

\section{Atitudes Pró-Ambiente}

\section{Grupo UFSCar}

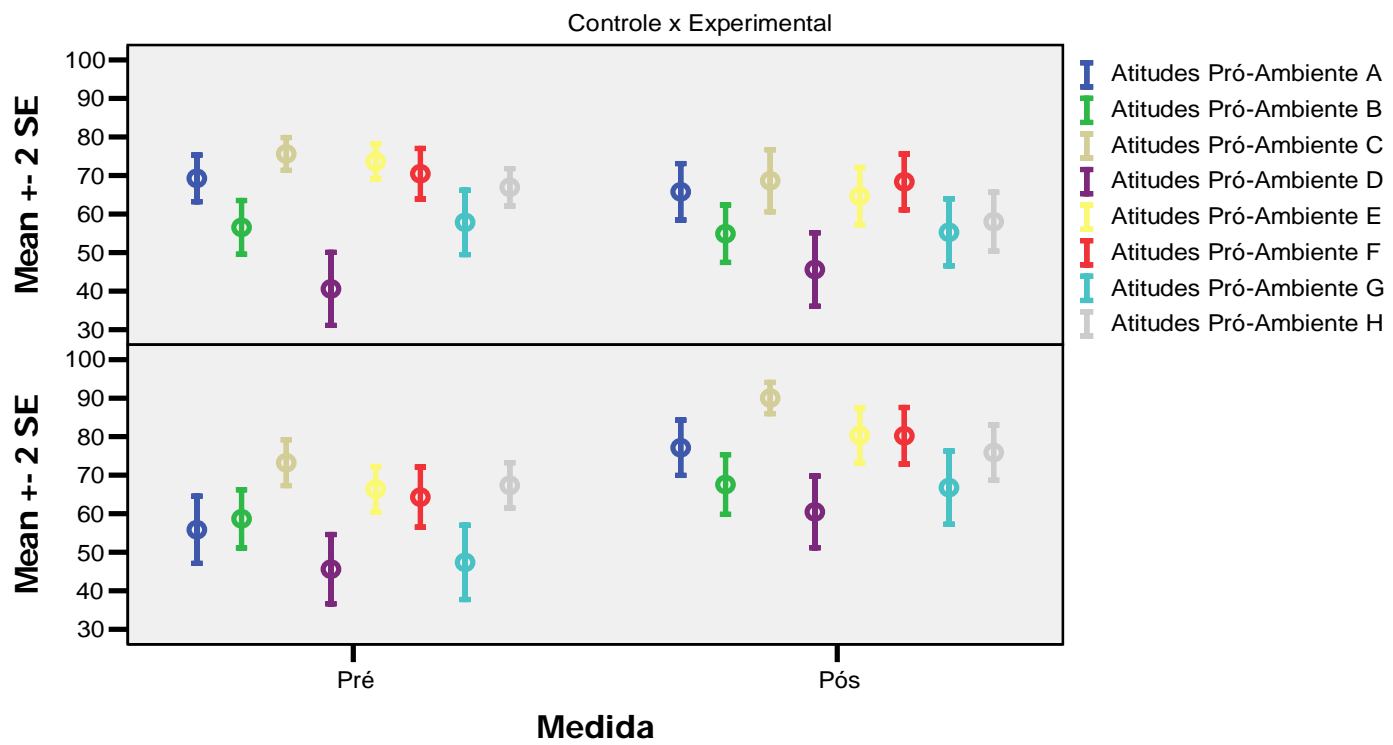


Atitudes Pró-Ambiente

\section{Grupo UFSCar}

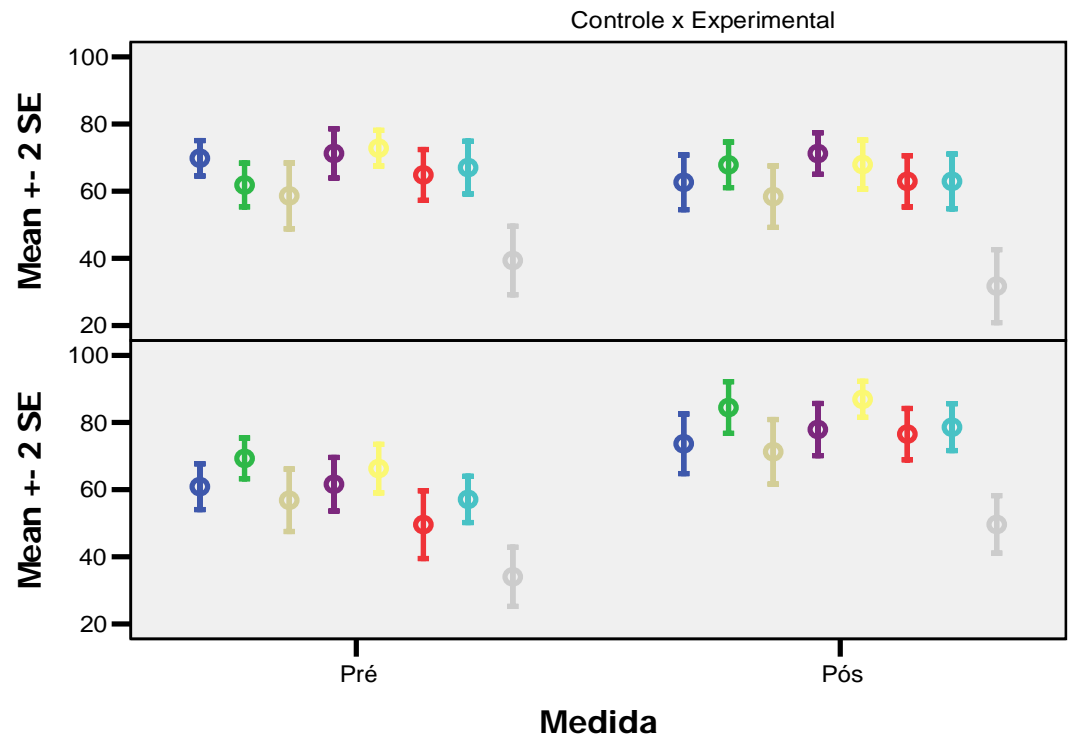

Afirmações referentes aos Paradigmas
Atitudes Pró-Ambiente I

I Atitudes Pró-Ambiente $\mathrm{J}$

Atitudes Pró-Ambiente $\mathrm{K}$

I Atitudes Pró-Ambiente L

Atitudes Pró-Ambiente $\mathrm{M}$

I Atitudes Pró-Ambiente $\mathrm{N}$

I Atitudes Pró-Ambiente $\mathrm{O}$

Atitudes Pró-Ambiente $P$

\section{Grupo UFSCar}

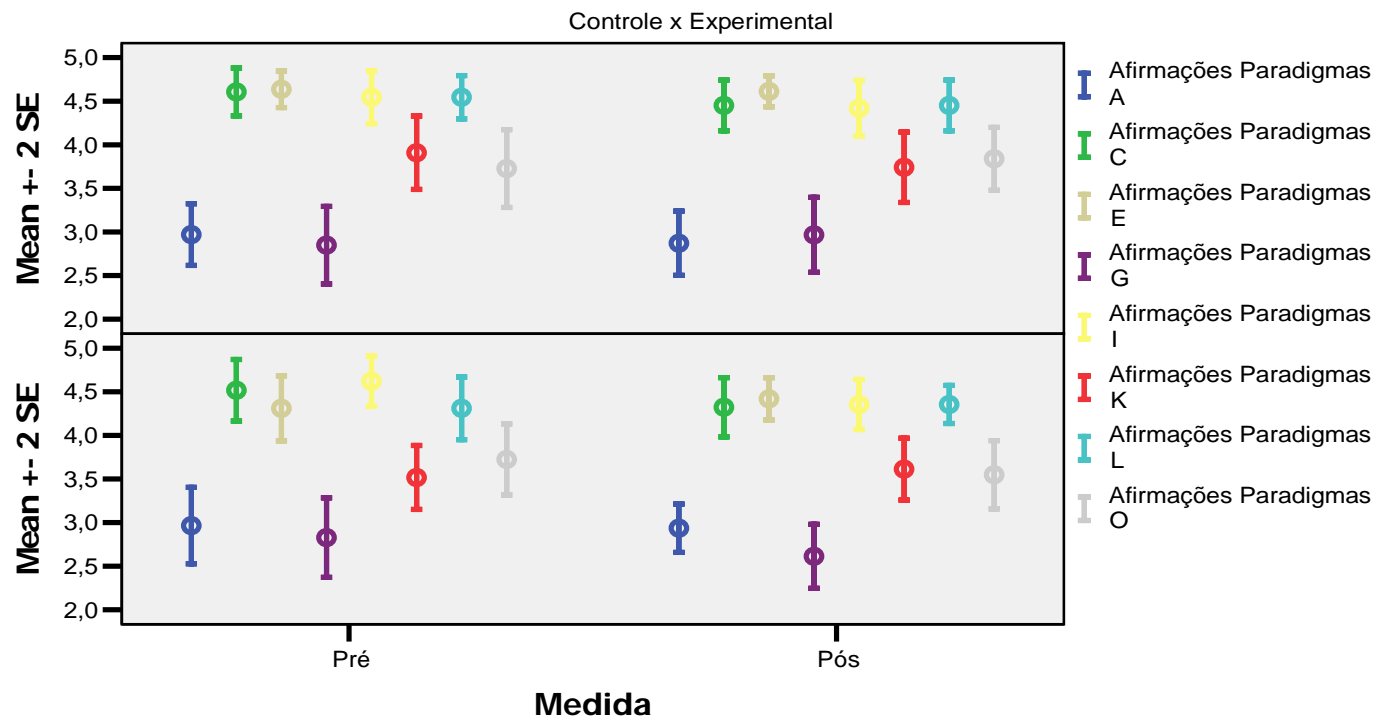




\section{Afirmações referentes aos Paradigmas}

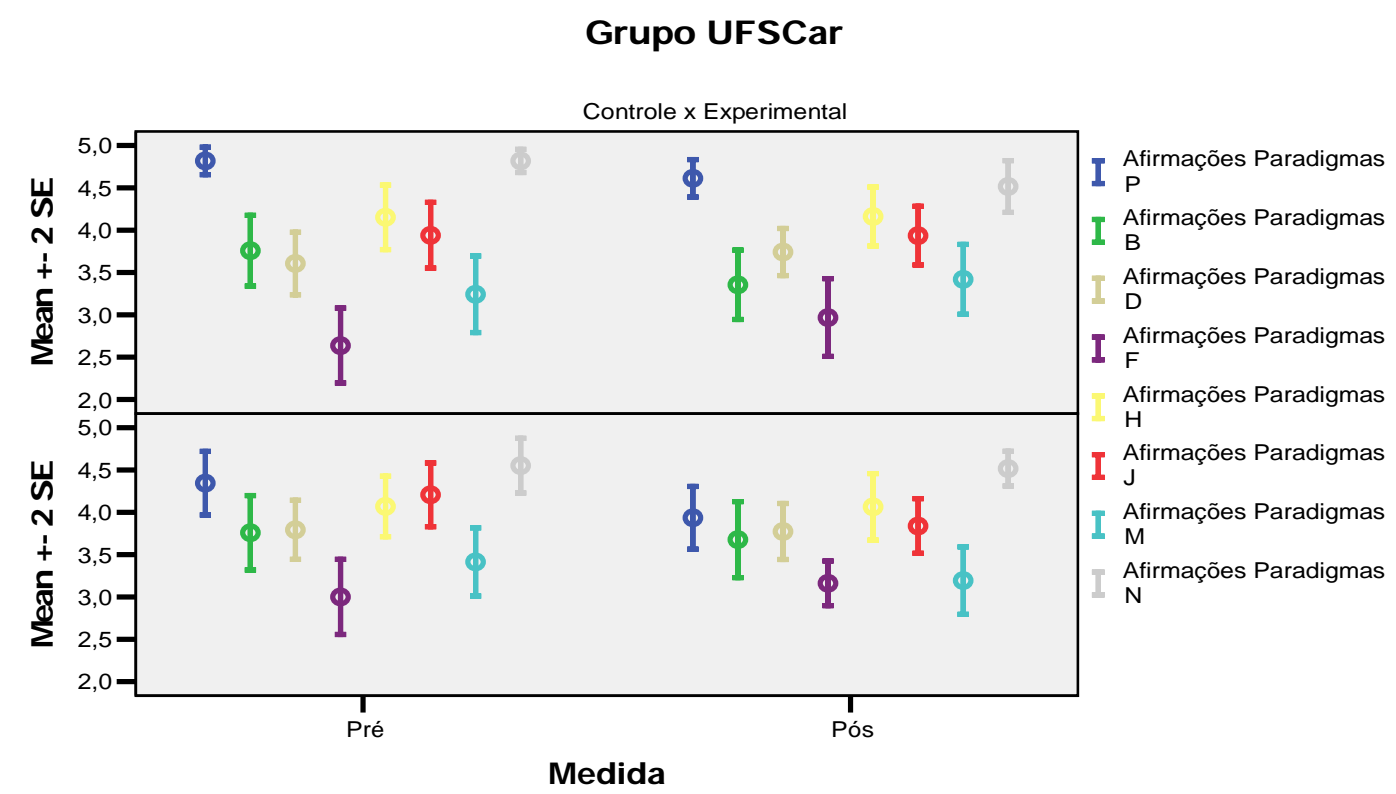

Percepções

Grupo UFSCar

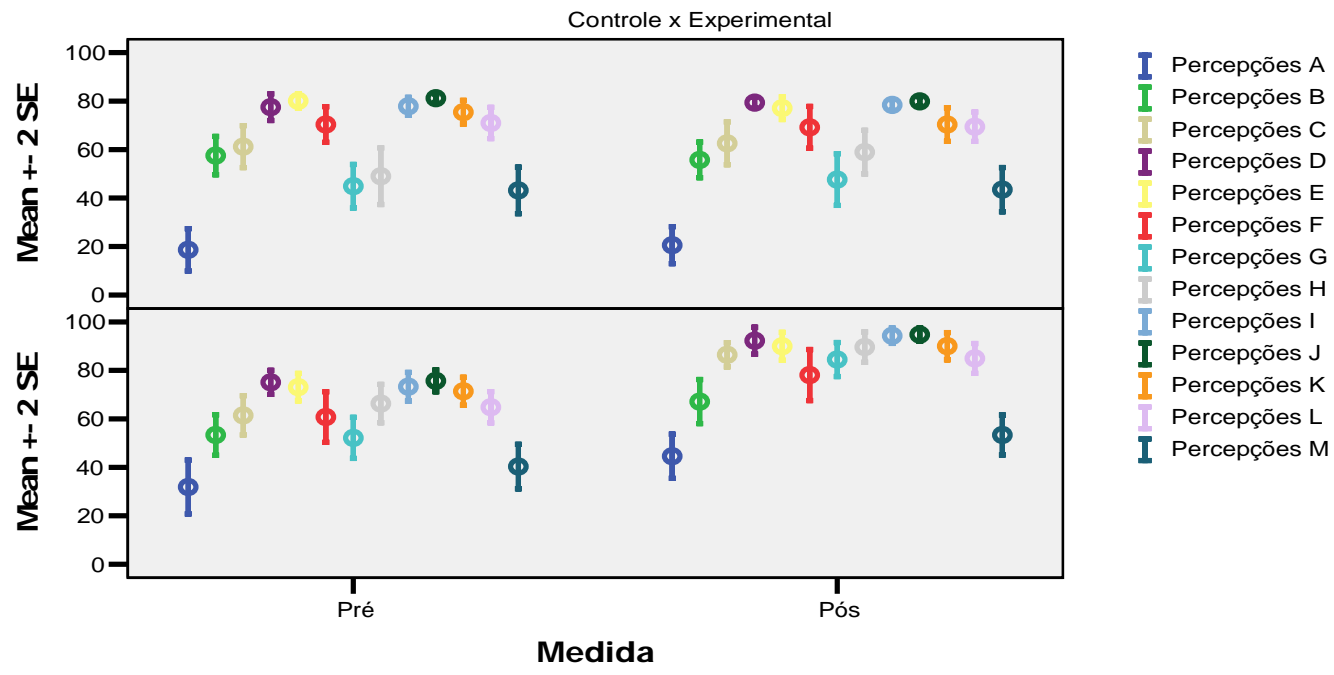




\section{ANEXO 4 - ANÁLISES ESTATÍSTICAS REFERENTES À DIFERENÇAS DE GÊNERO (ESTUDOS 3a E 3b)}

4A - No grupo Controle, Pré (continua...):

\begin{tabular}{llrrrrrrr}
\hline $\begin{array}{l}\text { Auto-avaliação do do } \\
\text { conhecimento }\end{array}$ & Sexo & $\mathrm{n}$ & Média & $\begin{array}{r}\text { Desvio } \\
\text { Padrão }\end{array}$ & Mín. & Mediana & Máx. & Valor $p$ \\
\hline Mata Atlântica & Feminino & 25 & 60,44 & 16,19 & 24 & 65,00 & 86 & 0,414 \\
& Masculino & 8 & 54,75 & 17,31 & 27 & 55,00 & 76 & \\
\hline Meio Ambiente & Feminino & 25 & 69,44 & 12,84 & 37 & 70,00 & 91 & 0,004 \\
& Masculino & 8 & 49,63 & 21,06 & 6 & 57,50 & 72 & \\
\hline Cavernas de & Feminino & 25 & 17,96 & 20,13 & 2 & 12,00 & 82 & 0,812 \\
Calcário & Masculino & 8 & 15,38 & 15,10 & 2 & 7,00 & 38 & \\
\hline Unidades de & Feminino & 25 & 48,72 & 19,11 & 4 & 52,00 & 82 & 0,643 \\
Conservação & Masculino & 8 & 44,13 & 18,94 & 12 & 47,50 & 64 & \\
\hline Educação & Feminino & 25 & 61,80 & 19,14 & 27 & 69,00 & 88 & 0,141 \\
Ambiental & Masculino & 8 & 50,88 & 20,26 & 15 & 53,50 & 72 & \\
\hline Comunidades & Feminino & 25 & 31,60 & 22,36 & 2 & 28,00 & 77 & 0,335 \\
Tradicionais & Masculino & 8 & 23,00 & 22,41 & 3 & 16,00 & 72 & \\
\hline
\end{tabular}


No grupo Controle, Pré (continuação 1):

\begin{tabular}{|c|c|c|c|c|c|c|c|c|}
\hline $\begin{array}{l}\text { Atitudes Pró- } \\
\text { Ambiente }\end{array}$ & Sexo & $\mathrm{n}$ & Média & $\begin{array}{l}\text { Desvio } \\
\text { Padrão }\end{array}$ & Mín. & Mediana & Máx. & Valor $p$ \\
\hline \multirow{2}{*}{$\begin{array}{l}\text { Participar do movi- } \\
\text { mento ambientalista }\end{array}$} & Feminino & 25 & 68,44 & 19,02 & 25 & 77,00 & 90 & 0,975 \\
\hline & Masculino & 8 & 71,88 & 11,36 & 54 & 72,50 & 85 & \\
\hline \multirow{2}{*}{$\begin{array}{l}\text { Mudar seus } \\
\text { hábitos de consumo }\end{array}$} & Feminino & 25 & 57,20 & 20,62 & 12 & 64,00 & 87 & 0,718 \\
\hline & Masculino & 8 & 54,50 & 19,35 & 25 & 55,50 & 77 & \\
\hline \multirow{2}{*}{$\begin{array}{l}\text { Visitar áreas } \\
\text { naturais }\end{array}$} & Feminino & 25 & 74,68 & 13,61 & 38 & 77,00 & 90 & 0,813 \\
\hline & Masculino & 8 & 78,50 & 5,98 & 68 & 78,50 & 86 & \\
\hline \multirow[t]{2}{*}{ Usar menos o carro } & Feminino & 25 & 34,32 & 27,58 & 1 & 30,00 & 81 & 0,013 \\
\hline & Masculino & 8 & 60,13 & 14,20 & 42 & 58,50 & 82 & \\
\hline \multirow{2}{*}{$\begin{array}{l}\text { Divulgar a preser- } \\
\text { vação ambiental }\end{array}$} & Feminino & 25 & 72,96 & 14,12 & 37 & 77,00 & 90 & 0,893 \\
\hline & Masculino & 8 & 75,75 & 10,05 & 55 & 76,00 & 90 & \\
\hline \multirow{2}{*}{$\begin{array}{l}\text { Fazer cursos } \\
\text { na área ambiental }\end{array}$} & Feminino & 25 & 70,96 & 20,41 & 2 & 77,00 & 90 & 0,426 \\
\hline & Masculino & 8 & 68,88 & 13,98 & 41 & 73,50 & 82 & \\
\hline \multirow{2}{*}{$\begin{array}{l}\text { Pesquisar/escrever } \\
\text { artigos de M. Amb. }\end{array}$} & Feminino & 25 & 61,44 & 19,54 & 24 & 65,00 & 90 & 0,346 \\
\hline & Masculino & 8 & 46,63 & 33,59 & 1 & 54,00 & 82 & \\
\hline \multirow{2}{*}{$\begin{array}{l}\text { Rever seus hábitos e } \\
\text { economizar recursos }\end{array}$} & Feminino & 25 & 66,72 & 13,72 & 35 & 68,00 & 85 & 0,781 \\
\hline & Masculino & 8 & 67,63 & 15,48 & 40 & 73,50 & 82 & \\
\hline \multirow{2}{*}{$\begin{array}{l}\text { Ler a respeito ou } \\
\text { assistir document. }\end{array}$} & Feminino & 25 & 70,72 & 15,41 & 34 & 75,00 & 97 & 0,542 \\
\hline & Masculino & 8 & 67,00 & 14,68 & 41 & 71,00 & 83 & \\
\hline \multirow{2}{*}{$\begin{array}{l}\text { Ser mais integrado } \\
\text { às outras pessoas }\end{array}$} & Feminino & 25 & 60,40 & 18,65 & 25 & 65,00 & 96 & 0,379 \\
\hline & Masculino & 8 & 66,38 & 19,10 & 38 & 70,00 & 89 & \\
\hline \multirow[t]{2}{*}{ Espiritualizar-se } & Feminino & 25 & 59,48 & 26,80 & 6 & 70,00 & 90 & 0,781 \\
\hline & Masculino & 8 & 55,88 & 34,01 & 2 & 68,50 & 88 & \\
\hline \multirow{2}{*}{$\begin{array}{l}\text { Cuidar de plantas e } \\
\text { animais }\end{array}$} & Feminino & 25 & 71,00 & 22,70 & 2 & 78,00 & 89 & 0,688 \\
\hline & Masculino & 8 & 72,00 & 15,98 & 40 & 77,00 & 88 & \\
\hline \multirow[t]{2}{*}{ Reciclar o lixo } & Feminino & 25 & 72,44 & 16,41 & 12 & 75,00 & 90 & 0,992 \\
\hline & Masculino & 8 & 74,00 & 11,50 & 54 & 76,50 & 88 & \\
\hline \multirow{2}{*}{$\begin{array}{l}\text { Filiar-se à uma } \\
\text { ONG ambientalista }\end{array}$} & Feminino & 25 & 64,84 & 23,28 & 2 & 74,00 & 90 & 0,781 \\
\hline & Masculino & 8 & 64,88 & 17,44 & 36 & 61,00 & 88 & \\
\hline \multirow{2}{*}{$\begin{array}{l}\text { Doar recursos ou } \\
\text { voluntariar-se }\end{array}$} & Feminino & 25 & 65,48 & 25,14 & 1 & 73,00 & 90 & 0,992 \\
\hline & Masculino & 8 & 71,88 & 11,03 & 60 & 72,00 & 88 & \\
\hline \multirow{2}{*}{$\begin{array}{l}\text { Pagar mais } \\
\text { impostos }\end{array}$} & Feminino & 25 & 38,96 & 28,80 & 1 & 37,00 & 88 & 0,797 \\
\hline & Masculino & 8 & 40,63 & 32,55 & 1 & 42,50 & 88 & \\
\hline
\end{tabular}


No grupo Controle, Pré (continuação 2):

\begin{tabular}{llrrrrrrr}
\hline Sentimentos & Sexo & $\mathrm{n}$ & Média & $\begin{array}{c}\text { Desvio } \\
\text { Padrão }\end{array}$ & Mín. & Mediana & Máx. & Valor $\mathrm{p}$ \\
\hline Alerta/sonolento & Feminino & 25 & 31,20 & 25,30 & 1 & 22,00 & 79 & 0,451 \\
& Masculino & 8 & 24,88 & 20,87 & 2 & 23,00 & 50 & \\
\hline calmo/agitado & Feminino & 25 & 42,04 & 24,73 & 2 & 47,00 & 80 & 0,335 \\
& Masculino & 8 & 34,88 & 32,07 & 2 & 32,50 & 96 & \\
\hline com idéias & Feminino & 25 & 46,68 & 30,50 & 2 & 50,00 & 80 & 0,613 \\
claras/confuso & Masculino & 8 & 41,38 & 32,05 & 9 & 38,50 & 96 & \\
\hline satisfeito/ & Feminino & 25 & 47,52 & 34,01 & 2 & 64,00 & 96 & 0,992 \\
insatisfeito & Masculino & 8 & 44,88 & 38,48 & 4 & 33,00 & 96 & \\
\hline tranqüilo/ & Feminino & 25 & 43,24 & 27,19 & 3 & 45,00 & 95 & 0,718 \\
preocupado & Masculino & 8 & 38,88 & 33,61 & 2 & 27,50 & 96 & \\
\hline atento/distraído & Feminino & 25 & 32,96 & 25,02 & 2 & 45,00 & 80 & 0,813 \\
& Masculino & 8 & 32,50 & 32,54 & 2 & 20,00 & 96 & \\
\hline alegre/triste & Feminino & 25 & 25,32 & 26,12 & 1 & 19,00 & 85 & 0,845 \\
& Masculino & 8 & 18,25 & 13,09 & 3 & 18,50 & 45 & \\
\hline interessado/ & Feminino & 25 & 39,84 & 30,21 & 2 & 32,00 & 96 & 0,119 \\
desinteressado & Masculino & 8 & 21,00 & 18,54 & 3 & 15,00 & 50 & \\
\hline seguro/inseguro & Feminino & 25 & 62,96 & 26,03 & 4 & 67,00 & 96 & 0,643 \\
& Masculino & 8 & 69,75 & 16,40 & 50 & 71,00 & 94 & \\
\hline solitário/ & Feminino & 25 & 50,68 & 26,24 & 2 & 50,00 & 90 & 0,159 \\
integrado & Masculino & 8 & 33,25 & 25,93 & 3 & 31,00 & 80 & \\
\hline confiante/ & Feminino & 25 & 35,72 & 26,21 & 2 & 26,00 & 83 & 0,542 \\
temeroso & Masculino & 8 & 30,13 & 29,86 & 3 & 20,00 & 80 & \\
\hline
\end{tabular}


No grupo Controle, Pré (continuação 3):

\begin{tabular}{|c|c|c|c|c|c|c|c|c|}
\hline Valores & Sexo & $\mathrm{n}$ & Média & $\begin{array}{l}\text { Desvio } \\
\text { Padrão }\end{array}$ & Mín. & Mediana & Máx. & Valor $p$ \\
\hline \multirow{2}{*}{$\begin{array}{l}\text { O que você acha da relação dos animais } \\
\text { da mata com o homem? Ruins/bons }\end{array}$} & Feminino & 25 & 15,84 & 23,74 & 1 & 5,00 & 77 & \multirow[t]{2}{*}{0,496} \\
\hline & Masculino & 8 & 27,38 & 28,60 & 1 & 21,00 & 74 & \\
\hline $\begin{array}{l}\text { O que você sente quando ouve falar sobre a } \\
\text { extinção de plantas e animais? }\end{array}$ & Feminino & 25 & 57,48 & 25,19 & 1 & 62,00 & 86 & \multirow[t]{2}{*}{0,489} \\
\hline Não posso fazer nada/Posso fazer muito & Masculino & 8 & 57,75 & 13,11 & 41 & 55,50 & 85 & \\
\hline Ao entrar em uma mata você fica: & Feminino & 25 & 59,96 & 27,51 & 1 & 68,00 & 87 & \multirow[t]{2}{*}{0,812} \\
\hline Com medo/Muito animado & Masculino & 8 & 65,13 & 13,86 & 42 & 64,50 & 84 & \\
\hline $\begin{array}{l}\text { O que você sente sobre a caça e a venda } \\
\text { de animais silvestres? }\end{array}$ & Feminino & 25 & 78,96 & 12,99 & 23 & 81,00 & 90 & \multirow[t]{2}{*}{0,860} \\
\hline Concordo totalmente/ Discordo totalmente & Masculino & 8 & 73,00 & 23,07 & 19 & 83,00 & 87 & \\
\hline \multirow{2}{*}{$\begin{array}{l}\text { O que você sente quando vê áreas de mata } \\
\text { queimando? Feliz/Triste }\end{array}$} & Feminino & 25 & 81,64 & 4,23 & 75 & 81,00 & 90 & \multirow[t]{2}{*}{0,342} \\
\hline & Masculino & 8 & 75,25 & 15,24 & 40 & 79,00 & 87 & \\
\hline $\begin{array}{l}\text { Garantir a preservação de uma espécie é } \\
\text { garantir a preservação da mata. }\end{array}$ & Feminino & 25 & 71,96 & 18,65 & 2 & 80,00 & 90 & 0,569 \\
\hline Concordo/Discordo & Masculino & 8 & 65,38 & 28,16 & 1 & 74,50 & 87 & \\
\hline \multirow{2}{*}{$\begin{array}{l}\text { Ao entra numa caverna de calcário você } \\
\text { fica: Com medo/Muito animado }\end{array}$} & Feminino & 25 & 46,20 & 28,14 & 1 & 38,00 & 87 & \multirow[t]{2}{*}{0,975} \\
\hline & Masculino & 8 & 40,88 & 16,63 & 8 & 38,50 & 61 & \\
\hline \multirow{2}{*}{$\begin{array}{l}\text { O modo de vida das populações tradicionais } \\
\text { deve ser mantido. Não Concordo/Concordo }\end{array}$} & Feminino & 25 & 49,56 & 35,09 & 1 & 65,00 & 87 & \multirow[t]{2}{*}{0,701} \\
\hline & Masculino & 8 & 47,25 & 30,23 & 1 & 49,50 & 87 & \\
\hline \multirow{2}{*}{$\begin{array}{l}\text { Visitar áreas naturais é: } \\
\text { Incômodo/Agadável }\end{array}$} & Feminino & 25 & 77,76 & 11,42 & 34 & 80,00 & 87 & \multirow[t]{2}{*}{0,731} \\
\hline & Masculino & 8 & 78,25 & 7,98 & 65 & 78,50 & 87 & \\
\hline \multirow{2}{*}{$\begin{array}{l}\text { A preservação da Mata Atlântica: } \\
\text { É urgente/ Não é urgente }\end{array}$} & Feminino & 25 & 81,68 & 4,06 & 75 & 80,00 & 90 & \multirow[t]{2}{*}{0,685} \\
\hline & Masculino & 8 & 79,63 & 7,03 & 69 & 82,00 & 87 & \\
\hline \multirow{2}{*}{$\begin{array}{l}\text { Quando estou em contato direto com a } \\
\text { Natureza eu me sinto: Isolado/Integrado }\end{array}$} & Feminino & 25 & 76,08 & 13,98 & 33 & 80,00 & 90 & \multirow[t]{2}{*}{0,626} \\
\hline & Masculino & 8 & 73,38 & 14,51 & 42 & 78,50 & 85 & \\
\hline \multirow{2}{*}{$\begin{array}{l}\text { A natureza ensina ao ser humano como ele } \\
\text { deve viver: Não concordo/Concordo }\end{array}$} & Feminino & 25 & 72,72 & 19,88 & 1 & 80,00 & 90 & \multirow[t]{2}{*}{0,049} \\
\hline & Masculino & 8 & 65,50 & 12,38 & 42 & 69,00 & 84 & \\
\hline $\begin{array}{l}\text { Os ambientalistas são pessoas que } \\
\text { deveriam pensar mais no desenvolvimento } \\
\text { da }\end{array}$ & Feminino & 25 & 44,68 & 28,16 & 1 & 40,00 & 82 & \multirow[t]{2}{*}{0,515} \\
\hline sociedade. Não concordo/Concordo & Masculino & 8 & 38,38 & 26,49 & 2 & 34,50 & 75 & \\
\hline
\end{tabular}


4B - No grupo Controle, Pós (continua...):

\begin{tabular}{llrrrrrrr}
\hline $\begin{array}{llrrr}\text { Auto-avaliação do } \\
\text { conhecimento }\end{array}$ & Sexo & $\mathrm{n}$ & Média & $\begin{array}{r}\text { Desvio } \\
\text { Padrão }\end{array}$ & Mín. & Mediana & Máx. & Valor $p$ \\
\hline Mata Atlântica & Feminino & 23 & 59,30 & 22,92 & 22 & 64,00 & 95 & 0,527 \\
& Masculino & 8 & 54,38 & 16,19 & 31 & 56,00 & 77 & \\
\hline Meio Ambiente & Feminino & 23 & 69,96 & 16,41 & 25 & 72,00 & 95 & 0,154 \\
& Masculino & 8 & 62,25 & 10,40 & 46 & 62,00 & 77 & \\
\hline Cavernas de & Feminino & 23 & 22,70 & 23,51 & 2 & 14,00 & 95 & 0,714 \\
Calcário & Masculino & 8 & 35,25 & 35,00 & 2 & 25,50 & 86 & \\
\hline Unidades de & Feminino & 23 & 55,61 & 21,18 & 18 & 60,00 & 95 & 0,471 \\
Conservação & Masculino & 8 & 49,13 & 19,32 & 28 & 48,00 & 79 & \\
\hline Educação & Feminino & 23 & 62,43 & 22,98 & 20 & 73,00 & 95 & 0,368 \\
Ambiental & Masculino & 8 & 57,25 & 15,07 & 32 & 61,00 & 77 & \\
\hline Comunidades & Feminino & 22 & 34,86 & 21,04 & 2 & 28,50 & 76 & 0,542 \\
Tradicionais & Masculino & 8 & 40,50 & 23,45 & 2 & 42,50 & 71 & \\
\hline
\end{tabular}


No grupo Controle, Pós (continuação 1):

\begin{tabular}{|c|c|c|c|c|c|c|c|c|}
\hline $\begin{array}{l}\text { Atitudes Pró- } \\
\text { Ambiente }\end{array}$ & Sexo & $\mathrm{n}$ & Média & $\begin{array}{l}\text { Desvio } \\
\text { Padrão }\end{array}$ & Mín. & Mediana & Máx. & Valor $p$ \\
\hline \multirow{2}{*}{$\begin{array}{l}\text { Participar do movi- } \\
\text { mento ambientalista }\end{array}$} & Feminino & 23 & 66,74 & 20,78 & 12 & 74,00 & 89 & 0,470 \\
\hline & Masculino & 8 & 63,00 & 20,24 & 29 & 68,50 & 85 & \\
\hline \multirow{2}{*}{$\begin{array}{l}\text { Mudar seus } \\
\text { hábitos de consumo }\end{array}$} & Feminino & 23 & 54,48 & 22,34 & 5 & 51,00 & 89 & 0,938 \\
\hline & Masculino & 8 & 56,13 & 16,51 & 39 & 56,00 & 85 & \\
\hline \multirow{2}{*}{$\begin{array}{l}\text { Visitar áreas } \\
\text { naturais }\end{array}$} & Feminino & 23 & 68,83 & 22,21 & 12 & 76,00 & 89 & 0,991 \\
\hline & Masculino & 8 & 68,13 & 24,47 & 12 & 78,00 & 85 & \\
\hline \multirow[t]{2}{*}{ Usar menos o carro } & Feminino & 23 & 45,87 & 29,35 & 1 & 40,00 & 89 & 0,938 \\
\hline & Masculino & 8 & 44,88 & 17,48 & 7 & 47,00 & 62 & \\
\hline \multirow{2}{*}{$\begin{array}{l}\text { Divulgar a preser- } \\
\text { vação ambiental }\end{array}$} & Feminino & 23 & 63,83 & 22,97 & 7 & 73,00 & 89 & 0,799 \\
\hline & Masculino & 8 & 67,13 & 12,88 & 47 & 70,00 & 85 & \\
\hline \multirow{2}{*}{$\begin{array}{l}\text { Fazer cursos } \\
\text { na área ambiental }\end{array}$} & Feminino & 23 & 68,22 & 22,17 & 10 & 77,00 & 89 & 0,527 \\
\hline & Masculino & 8 & 68,75 & 14,02 & 47 & 74,50 & 85 & \\
\hline \multirow{2}{*}{$\begin{array}{l}\text { Pesquisar e } \\
\text { escrever } \\
\text { artigos de M. Amb. }\end{array}$} & Feminino & 23 & 59,30 & 23,32 & 5 & 64,00 & 86 & 0,118 \\
\hline & Masculino & 8 & 43,63 & 24,45 & 2 & 51,50 & 74 & \\
\hline $\begin{array}{l}\text { Rever seus hábitos } \\
\text { e }\end{array}$ & Feminino & 23 & 58,39 & 23,87 & 5 & 65,00 & 89 & 0,557 \\
\hline economizar recursos & Masculino & 8 & 57,00 & 12,63 & 37 & 57,00 & 75 & \\
\hline \multirow{2}{*}{$\begin{array}{l}\text { Ler a respeito ou } \\
\text { assistir document. }\end{array}$} & Feminino & 23 & 67,65 & 21,55 & 3 & 72,00 & 89 & 0,017 \\
\hline & Masculino & 8 & 48,25 & 20,41 & 20 & 42,50 & 85 & \\
\hline \multirow{2}{*}{$\begin{array}{l}\text { Ser mais integrado } \\
\text { às outras pessoas }\end{array}$} & Feminino & 23 & 67,65 & 19,81 & 11 & 75,00 & 89 & 0,903 \\
\hline & Masculino & 8 & 68,38 & 16,89 & 37 & 72,50 & 85 & \\
\hline \multirow[t]{2}{*}{ Espiritualizar-se } & Feminino & 23 & 62,52 & 23,95 & 10 & 75,00 & 89 & 0,135 \\
\hline & Masculino & 8 & 46,50 & 27,72 & 1 & 50,00 & 85 & \\
\hline \multirow{2}{*}{$\begin{array}{l}\text { Cuidar de plantas e } \\
\text { animais }\end{array}$} & Feminino & 23 & 72,91 & 17,36 & 10 & 78,00 & 89 & 0,332 \\
\hline & Masculino & 8 & 66,38 & 16,81 & 40 & 68,00 & 85 & \\
\hline \multirow[t]{2}{*}{ Reciclar o lixo } & Feminino & 23 & 72,43 & 15,94 & 12 & 75,00 & 89 & 0,141 \\
\hline & Masculino & 8 & 55,00 & 26,43 & 18 & 58,00 & 85 & \\
\hline \multirow{2}{*}{$\begin{array}{l}\text { Filiar-se à uma } \\
\text { ONG ambientalista }\end{array}$} & Feminino & 23 & 65,61 & 21,59 & 14 & 72,00 & 89 & 0,190 \\
\hline & Masculino & 8 & 55,25 & 19,26 & 25 & 53,50 & 85 & \\
\hline \multirow{2}{*}{$\begin{array}{l}\text { Doar recursos ou } \\
\text { voluntariar-se }\end{array}$} & Feminino & 23 & 64,61 & 25,26 & 2 & 76,00 & 89 & 0,175 \\
\hline & Masculino & 8 & 58,13 & 12,79 & 45 & 54,50 & 85 & \\
\hline \multirow{2}{*}{$\begin{array}{l}\text { Pagar mais } \\
\text { impostos }\end{array}$} & Feminino & 23 & 31,74 & 31,07 & 1 & 15,00 & 89 & 0,885 \\
\hline & Masculino & 8 & 31,75 & 29,77 & 1 & 25,00 & 85 & \\
\hline
\end{tabular}


No grupo Controle, Pós (continuação 2):

\begin{tabular}{llrrrrrrr}
\hline Sentimentos & Sexo & $\mathrm{n}$ & Média & $\begin{array}{r}\text { Desvio } \\
\text { Padrão }\end{array}$ & Mín. & Mediana & Máx. & Valor p \\
\hline Alerta/sonolento & Feminino & 23 & 51,13 & 32,20 & 5 & 57,00 & 95 & 0,834 \\
& Masculino & 8 & 49,88 & 34,16 & 4 & 54,00 & 95 & \\
\hline calmo/agitado & Feminino & 23 & 55,09 & 26,92 & 4 & 62,00 & 95 & 0,417 \\
& Masculino & 8 & 42,38 & 34,93 & 4 & 31,00 & 95 & \\
\hline com idéias & Feminino & 23 & 48,22 & 27,05 & 3 & 47,00 & 95 & 0,991 \\
claras/confuso & Masculino & 8 & 48,13 & 24,62 & 9 & 55,50 & 80 & \\
\hline satisfeito/ & Feminino & 23 & 65,48 & 22,75 & 3 & 74,00 & 95 & 0,118 \\
insatisfeito & Masculino & 8 & 47,00 & 28,06 & 20 & 39,50 & 94 & \\
\hline tranqüilo/ & Feminino & 23 & 39,39 & 27,68 & 1 & 35,00 & 95 & 0,886 \\
preocupado & Masculino & 8 & 40,13 & 28,18 & 11 & 32,50 & 95 & \\
\hline atento/distraído & Feminino & 23 & 42,83 & 26,19 & 3 & 45,00 & 95 & 0,142 \\
& Masculino & 8 & 28,50 & 24,11 & 1 & 25,00 & 75 & \\
\hline alegre/triste & Feminino & 23 & 32,22 & 23,24 & 1 & 21,00 & 77 & 0,526 \\
& Masculino & 8 & 27,38 & 28,10 & 1 & 20,00 & 94 & \\
\hline interessado/ & Feminino & 23 & 51,43 & 27,97 & 3 & 56,00 & 95 & 0,012 \\
desinteressado & Masculino & 8 & 22,75 & 21,58 & 1 & 16,50 & 60 & \\
\hline seguro/inseguro & Feminino & 23 & 53,35 & 30,78 & 1 & 54,00 & 95 & 0,698 \\
& Masculino & 8 & 49,63 & 30,12 & 15 & 51,00 & 86 & \\
\hline solitário/ & Feminino & 23 & 57,04 & 27,55 & 3 & 70,00 & 95 & 0,039 \\
integrado & Masculino & 8 & 30,25 & 30,75 & 2 & 19,00 & 80 & \\
\hline confiante/ & Feminino & 23 & 52,13 & 28,43 & 2 & 49,00 & 95 & 0,107 \\
temeroso & Masculino & 8 & 33,13 & 26,54 & 2 & 23,00 & 77 & \\
\hline
\end{tabular}


No grupo Controle, Pós (continuação 3):

\begin{tabular}{|c|c|c|c|c|c|c|c|c|}
\hline Valores & Sexo & $\mathrm{n}$ & Média & $\begin{array}{l}\text { Desvio } \\
\text { Padrão }\end{array}$ & Mín. & Mediana & Máx. & Valor $p$ \\
\hline \multirow{2}{*}{$\begin{array}{l}\text { O que você acha da relação } \\
\text { dos animais } \\
\text { da mata com o homem? } \\
\text { Ruins/bons }\end{array}$} & Feminino & 23 & 16,57 & 18,94 & 1 & 8,00 & 68 & \multirow[t]{2}{*}{0,101} \\
\hline & Masculino & 8 & 32,00 & 24,44 & 1 & 34,00 & 60 & \\
\hline \multirow{2}{*}{$\begin{array}{l}\text { O que você sente quando } \\
\text { ouve falar sobre a } \\
\text { extinção de plantas e } \\
\text { animais? Não posso fazer } \\
\text { nada/Posso fazer muito }\end{array}$} & Feminino & 23 & 55,78 & 23,57 & 7 & 57,00 & 85 & \multirow[t]{2}{*}{0,649} \\
\hline & Masculino & 8 & 55,63 & 6,57 & 42 & 56,00 & 62 & \\
\hline \multirow{2}{*}{$\begin{array}{l}\text { Ao entrar em uma mata você } \\
\text { fica: Com medo/Muito } \\
\text { animado }\end{array}$} & Feminino & 23 & 64,35 & 23,96 & 5 & 74,00 & 86 & \multirow[t]{2}{*}{0,513} \\
\hline & Masculino & 8 & 57,50 & 27,13 & 9 & 62,50 & 84 & \\
\hline $\begin{array}{l}\text { O que você sente sobre a } \\
\text { caça e a venda de } \\
\text { animais silvestres? Concordo } \\
\text { totalmente/ Discordo } \\
\text { totalmente }\end{array}$ & Feminino & 23 & 79,22 & 5,21 & 67 & 80,00 & 86 & 0,352 \\
\hline \multirow{2}{*}{$\begin{array}{l}\text { O que você sente quando vê } \\
\text { áreas de mata } \\
\text { queimando? Feliz/Triste }\end{array}$} & Feminino & 23 & 80,00 & 3,38 & 74 & 80,00 & 86 & \multirow[t]{2}{*}{0,116} \\
\hline & Masculino & 8 & 68,75 & 24,08 & 11 & 76,50 & 85 & \\
\hline $\begin{array}{l}\text { Garantir a preservação de } \\
\text { uma espécie é garantir a } \\
\text { preservação da mata. } \\
\text { Concordo/Discordo }\end{array}$ & Feminino & 23 & 70,30 & 23,18 & 1 & 77,00 & 86 & 0,633 \\
\hline \multirow{2}{*}{$\begin{array}{l}\text { Ao entra numa caverna de } \\
\text { calcário você fica: } \\
\text { Com medo/Muito animado }\end{array}$} & Feminino & 23 & 45,35 & 30,61 & 1 & 37,00 & 85 & \multirow[t]{2}{*}{0,682} \\
\hline & Masculino & 8 & 54,13 & 27,18 & 15 & 59,00 & 85 & \\
\hline $\begin{array}{l}\text { O modo de vida das } \\
\text { populações tradicionais } \\
\text { deve ser mantido. Não } \\
\text { Concordo/Concordo }\end{array}$ & Feminino & 23 & 58,30 & 26,37 & 25 & 72,00 & 85 & 0,730 \\
\hline $\begin{array}{l}\text { Visitar áreas naturais é: } \\
\text { Incômodo/Agadável }\end{array}$ & $\begin{array}{l}\text { Feminino } \\
\text { Masculino }\end{array}$ & $\begin{array}{l}23 \\
8\end{array}$ & $\begin{array}{l}78,00 \\
79,75\end{array}$ & $\begin{array}{l}5,90 \\
6,84\end{array}$ & $\begin{array}{l}62 \\
67\end{array}$ & $\begin{array}{l}80,00 \\
81,50\end{array}$ & $\begin{array}{l}86 \\
87\end{array}$ & 0,365 \\
\hline \multirow{2}{*}{$\begin{array}{l}\text { A preservação da Mata } \\
\text { Atlântica: } \\
\text { É urgente/ Não é urgente }\end{array}$} & Feminino & 23 & 79,65 & 4,52 & 70 & 80,00 & 86 & \multirow[t]{2}{*}{0,307} \\
\hline & Masculino & 8 & 80,63 & 7,37 & 67 & 83,00 & 87 & \\
\hline \multirow{2}{*}{$\begin{array}{l}\text { Quando estou em contato } \\
\text { direto com a Natureza eu } \\
\text { me sinto: Isolado/Integrado }\end{array}$} & Feminino & 23 & 72,00 & 16,50 & 5 & 75,00 & 86 & \multirow[t]{2}{*}{0,991} \\
\hline & Masculino & 8 & 65,63 & 26,61 & 11 & 75,00 & 87 & \\
\hline $\begin{array}{l}\text { A natureza ensina ao ser } \\
\text { humano como ele deve } \\
\text { viver: Não } \\
\text { concordo/Concordo }\end{array}$ & Feminino & 23 & 69,48 & 18,61 & 55 & 77,00 & 86 & 0,587 \\
\hline $\begin{array}{l}\text { Os ambientalistas são } \\
\text { pessoas que deveriam } \\
\text { pensar mais no } \\
\text { desenvolvimento da } \\
\text { sociedade. Não } \\
\text { concordo/Concordo }\end{array}$ & Feminino & 23 & 46,65 & 26,87 & 1 & 44,00 & 85 & 0,344 \\
\hline
\end{tabular}


4C - No grupo Experimento, Pré (continua...):

\begin{tabular}{|c|c|c|c|c|c|c|c|c|}
\hline $\begin{array}{l}\text { Auto-avaliação } \\
\text { do conhecimento }\end{array}$ & Sexo & $\mathrm{n}$ & Média & $\begin{array}{l}\text { Desvio } \\
\text { Padrão }\end{array}$ & Mín. & Mediana & Máx. & Valor $p$ \\
\hline \multirow[t]{2}{*}{ Mata Atlântica } & Feminino & 20 & 59,60 & 20,05 & 23 & 57,00 & 96 & 1,000 \\
\hline & Masculino & 9 & 58,78 & 14,04 & 40 & 56,00 & 80 & \\
\hline \multirow[t]{2}{*}{ Meio Ambiente } & Feminino & 20 & 62,70 & 17,12 & 36 & 63,50 & 96 & 0,737 \\
\hline & Masculino & 9 & 65,33 & 18,34 & 36 & 67,00 & 95 & \\
\hline Cavernas de & Feminino & 20 & 20,95 & 14,79 & 4 & 17,00 & 54 & 0,258 \\
\hline Calcário & Masculino & 9 & 16,44 & 16,53 & 2 & 10,00 & 50 & \\
\hline Unidades de & Feminino & 20 & 52,10 & 20,59 & 12 & 51,00 & 96 & 0,826 \\
\hline Conservação & Masculino & 9 & 53,44 & 17,53 & 29 & 52,00 & 77 & \\
\hline Educação & Feminino & 20 & 64,55 & 18,73 & 20 & 64,00 & 96 & 0,702 \\
\hline Ambiental & Masculino & 9 & 64,78 & 20,15 & 40 & 58,00 & 95 & \\
\hline Comunidades & Feminino & 20 & 35,00 & 25,43 & 2 & 28,00 & 95 & 0,554 \\
\hline Tradicionais & Masculino & 9 & 28,56 & 23,41 & 2 & 27,00 & 66 & \\
\hline
\end{tabular}


No grupo Experimento, Pré (continuação 1):

\begin{tabular}{|c|c|c|c|c|c|c|c|c|}
\hline $\begin{array}{l}\text { Atitudes Pró- } \\
\text { Ambiente }\end{array}$ & Sexo & $\mathrm{n}$ & Média & $\begin{array}{l}\text { Desvio } \\
\text { Padrão }\end{array}$ & Mín. & Mediana & Máx. & Valor $p$ \\
\hline \multirow{2}{*}{$\begin{array}{l}\text { Participar do movi- } \\
\text { mento ambientalista }\end{array}$} & Feminino & 20 & 55,00 & 22,07 & 3 & 58,00 & 86 & 0,570 \\
\hline & Masculino & 9 & 57,67 & 27,69 & 10 & 72,00 & 85 & \\
\hline \multirow{2}{*}{$\begin{array}{l}\text { Mudar seus } \\
\text { hábitos de consumo }\end{array}$} & Feminino & 20 & 57,40 & 20,48 & 2 & 59,00 & 86 & 0,618 \\
\hline & Masculino & 9 & 61,56 & 20,92 & 24 & 60,00 & 85 & \\
\hline \multirow{2}{*}{$\begin{array}{l}\text { Visitar áreas } \\
\text { naturais }\end{array}$} & Feminino & 20 & 70,00 & 18,17 & 20 & 76,00 & 86 & $\underline{0,086}$ \\
\hline & Masculino & 9 & 80,44 & 5,08 & 70 & 82,00 & 85 & \\
\hline \multirow[t]{2}{*}{ Usar menos o carro } & Feminino & 20 & 45,35 & 23,33 & 1 & 40,00 & 86 & 0,935 \\
\hline & Masculino & 9 & 46,22 & 27,47 & 8 & 35,00 & 85 & \\
\hline \multirow{2}{*}{$\begin{array}{l}\text { Divulgar a preser- } \\
\text { vação ambiental }\end{array}$} & Feminino & 20 & 63,95 & 15,02 & 40 & 66,50 & 86 & 0,237 \\
\hline & Masculino & 9 & 71,78 & 17,08 & 42 & 80,00 & 85 & \\
\hline \multirow{2}{*}{$\begin{array}{l}\text { Fazer cursos } \\
\text { na área ambiental }\end{array}$} & Feminino & 20 & 62,65 & 18,71 & 20 & 65,00 & 86 & 0,220 \\
\hline & Masculino & 9 & 68,00 & 26,32 & 1 & 75,00 & 85 & \\
\hline \multirow{2}{*}{$\begin{array}{l}\text { Pesquisar e } \\
\text { escrever artigos de } \\
\text { Meio Ambiente }\end{array}$} & Feminino & 20 & 45,80 & 24,59 & 1 & 39,00 & 86 & 0,524 \\
\hline & Masculino & 9 & 50,89 & 29,99 & 10 & 44,00 & 85 & \\
\hline \multirow{2}{*}{$\begin{array}{l}\text { Rever seus hábitos } \\
\text { economizar recursos }\end{array}$} & Feminino & 20 & 68,90 & 12,93 & 40 & 70,00 & 86 & 0,790 \\
\hline & Masculino & 9 & 64,00 & 21,38 & 36 & 67,00 & 85 & \\
\hline \multirow{2}{*}{$\begin{array}{l}\text { Ler a respeito ou } \\
\text { assistir document. }\end{array}$} & Feminino & 20 & 63,45 & 17,20 & 32 & 66,50 & 86 & 0,238 \\
\hline & Masculino & 9 & 55,22 & 20,64 & 25 & 62,00 & 85 & \\
\hline \multirow{2}{*}{$\begin{array}{l}\text { Ser mais integrado } \\
\text { às outras pessoas }\end{array}$} & Feminino & 20 & 70,15 & 15,33 & 35 & 74,50 & 86 & 0,991 \\
\hline & Masculino & 9 & 67,44 & 19,16 & 38 & 78,00 & 85 & \\
\hline \multirow[t]{2}{*}{ Espiritualizar-se } & Feminino & 20 & 56,40 & 22,87 & 1 & 60,00 & 86 & 0,807 \\
\hline & Masculino & 9 & 57,78 & 30,70 & 1 & 70,00 & 85 & \\
\hline \multirow{2}{*}{$\begin{array}{l}\text { Cuidar de plantas e } \\
\text { animais }\end{array}$} & Feminino & 20 & 60,80 & 22,35 & 8 & 63,50 & 86 & 0,935 \\
\hline & Masculino & 9 & 63,44 & 20,67 & 35 & 70,00 & 85 & \\
\hline \multirow[t]{2}{*}{ Reciclar o lixo } & Feminino & 20 & 63,20 & 19,48 & 27 & 66,00 & 90 & 0,156 \\
\hline & Masculino & 9 & 73,11 & 18,39 & 40 & 82,00 & 85 & \\
\hline \multirow{2}{*}{$\begin{array}{l}\text { Filiar-se à uma } \\
\text { ONG ambientalista }\end{array}$} & Feminino & 20 & 50,95 & 23,57 & 1 & 47,00 & 86 & 0,755 \\
\hline & Masculino & 9 & 46,56 & 35,51 & 1 & 40,00 & 85 & \\
\hline \multirow{2}{*}{$\begin{array}{l}\text { Doar recursos ou } \\
\text { voluntariar-se }\end{array}$} & Feminino & 20 & 53,90 & 16,44 & 35 & 52,00 & 85 & 0,163 \\
\hline & Masculino & 9 & 64,22 & 21,87 & 24 & 70,00 & 85 & \\
\hline \multirow{2}{*}{$\begin{array}{l}\text { Pagar mais } \\
\text { impostos }\end{array}$} & Feminino & 20 & 33,80 & 20,01 & 1 & 37,00 & 80 & 0,808 \\
\hline & Masculino & 9 & 34,56 & 31,89 & 1 & 37,00 & 85 & \\
\hline
\end{tabular}


No grupo Experimento, Pré (continuação 2):

\begin{tabular}{llrrrrrrr}
\hline Sentimentos & Sexo & $\mathrm{n}$ & Média & $\begin{array}{r}\text { Desvio } \\
\text { Padrão }\end{array}$ & Mín. & Mediana & Máx. & Valor $p$ \\
\hline Alerta/sonolento & Feminino & 20 & 34,45 & 31,50 & 2 & 20,00 & 95 & 0,102 \\
& Masculino & 9 & 10,78 & 6,80 & 2 & 13,00 & 21 & \\
\hline calmo/agitado & Feminino & 20 & 50,75 & 24,50 & 4 & 49,50 & 95 & $\underline{0,053}$ \\
& Masculino & 9 & 31,67 & 27,59 & 2 & 26,00 & 85 & \\
\hline com idéias & Feminino & 20 & 35,75 & 22,93 & 4 & 40,00 & 77 & 0,409 \\
claras/confuso & Masculino & 9 & 32,22 & 25,30 & 2 & 45,00 & 73 & \\
\hline satisfeito/ & Feminino & 20 & 36,90 & 30,70 & 2 & 28,00 & 95 & 0,102 \\
insatisfeito & Masculino & 9 & 55,78 & 33,91 & 6 & 68,00 & 96 & \\
\hline tranqüilo/ & Feminino & 20 & 39,80 & 30,57 & 3 & 31,50 & 96 & 0,097 \\
preocupado & Masculino & 9 & 21,33 & 22,27 & 2 & 12,00 & 69 & \\
\hline atento/distraído & Feminino & 20 & 27,90 & 20,47 & 3 & 23,50 & 70 & 0,635 \\
& Masculino & 9 & 25,89 & 25,90 & 2 & 16,00 & 77 & \\
\hline alegre/triste & Feminino & 20 & 16,45 & 12,58 & 2 & 15,00 & 48 & 0,826 \\
& Masculino & 9 & 22,22 & 23,06 & 2 & 11,00 & 71 & \\
\hline interessado/ & Feminino & 20 & 34,55 & 21,08 & 4 & 37,00 & 72 & 0,844 \\
desinteressado & Masculino & 9 & 38,22 & 36,45 & 3 & 15,00 & 95 & \\
\hline seguro/inseguro & Feminino & 20 & 47,20 & 28,72 & 2 & 47,50 & 95 & 0,267 \\
& Masculino & 9 & 61,22 & 27,77 & 16 & 50,00 & 95 & \\
\hline solitário/ & Feminino & 20 & 39,70 & 25,03 & 3 & 38,00 & 92 & 0,156 \\
integrado & Masculino & 9 & 26,44 & 28,94 & 3 & 16,00 & 95 & \\
\hline confiante/ & Feminino & 20 & 33,65 & 21,81 & 3 & 39,50 & 75 & 0,494 \\
temeroso & Masculino & 9 & 30,22 & 26,92 & 2 & 42,00 & 72 & \\
\hline
\end{tabular}


No grupo Experimento, Pré (continuação 3):

\begin{tabular}{|c|c|c|c|c|c|c|c|c|}
\hline Valores & Sexo & $\mathrm{n}$ & Média & $\begin{array}{l}\text { Desvio } \\
\text { Padrão }\end{array}$ & Mín. & Mediana & Máx. & Valor $\mathrm{p}$ \\
\hline \multirow{2}{*}{$\begin{array}{l}\text { O que você acha da relação } \\
\text { dos animais } \\
\text { da mata com o homem? } \\
\text { Ruins/bons }\end{array}$} & Feminino & 20 & 32,70 & 27,90 & 1 & 27,50 & 86 & 0,538 \\
\hline & Masculino & 9 & 30,11 & 35,60 & 1 & 14,00 & 82 & \\
\hline \multirow{2}{*}{$\begin{array}{l}\text { O que você sente quando } \\
\text { ouve falar sobre a } \\
\text { extinção de plantas e animais? } \\
\text { Não posso fazer nada/Posso } \\
\text { fazer muito }\end{array}$} & Feminino & 20 & 56,55 & 20,54 & 11 & 58,50 & 86 & 0,334 \\
\hline & Masculino & 9 & 46,22 & 26,24 & 12 & 42,00 & 85 & \\
\hline \multirow{2}{*}{$\begin{array}{l}\text { Ao entrar em uma mata você } \\
\text { fica: } \\
\text { Com medo/Muito animado }\end{array}$} & Feminino & 20 & 55,00 & 22,79 & 12 & 57,00 & 86 & 0,027 \\
\hline & Masculino & 9 & 75,78 & 9,20 & 61 & 75,00 & 85 & \\
\hline \multirow{2}{*}{$\begin{array}{l}\text { O que você sente sobre a caça } \\
\text { e a venda de } \\
\text { animais silvestres? Concordo } \\
\text { totalmente/ Discordo } \\
\text { totalmente }\end{array}$} & Feminino & 20 & 72,60 & 15,10 & 34 & 77,50 & 86 & 0,135 \\
\hline & Masculino & 9 & 80,56 & 5,70 & 70 & 82,00 & 85 & \\
\hline \multirow{2}{*}{$\begin{array}{l}\text { O que você sente quando vê } \\
\text { áreas de mata } \\
\text { queimando? Feliz/Triste }\end{array}$} & Feminino & 20 & 69,80 & 16,89 & 32 & 74,50 & 86 & $\underline{0,069}$ \\
\hline & Masculino & 9 & 80,44 & 6,50 & 66 & 82,00 & 85 & \\
\hline \multirow{2}{*}{$\begin{array}{l}\text { Garantir a preservação de uma } \\
\text { espécie é garantir a } \\
\text { preservação da mata. } \\
\text { Concordo/Discordo }\end{array}$} & Feminino & 20 & 61,60 & 24,88 & 5 & 72,50 & 86 & 0,808 \\
\hline & Masculino & 9 & 58,89 & 35,68 & 1 & 79,00 & 85 & \\
\hline \multirow{2}{*}{$\begin{array}{l}\text { Ao entra numa caverna de } \\
\text { calcário você fica: } \\
\text { Com medo/Muito animado }\end{array}$} & Feminino & 20 & 51,50 & 20,80 & 10 & 43,50 & 86 & 0,826 \\
\hline & Masculino & 9 & 53,56 & 27,96 & 7 & 40,00 & 85 & \\
\hline \multirow{2}{*}{$\begin{array}{l}\text { O modo de vida das } \\
\text { populações tradicionais } \\
\text { deve ser mantido. Não } \\
\text { Concordo/Concordo }\end{array}$} & Feminino & 20 & 66,10 & 18,82 & 22 & 71,00 & 86 & 0,521 \\
\hline & Masculino & 9 & 66,78 & 27,16 & 6 & 80,00 & 85 & \\
\hline \multirow{2}{*}{$\begin{array}{l}\text { Visitar áreas naturais é: } \\
\text { Incômodo/Agadável }\end{array}$} & Feminino & 20 & 70,20 & 18,09 & 11 & 76,00 & 86 & 0,111 \\
\hline & Masculino & 9 & 80,11 & 5,51 & 71 & 81,00 & 85 & \\
\hline \multirow{2}{*}{$\begin{array}{l}\text { A preservação da Mata } \\
\text { Atlântica: } \\
\text { É urgente/ Não é urgente }\end{array}$} & Feminino & 20 & 73,20 & 13,57 & 27 & 76,00 & 86 & 0,100 \\
\hline & Masculino & 9 & 81,22 & 4,89 & 71 & 82,00 & 85 & \\
\hline \multirow{2}{*}{$\begin{array}{l}\text { Quando estou em contato } \\
\text { direto com a Natureza eu } \\
\text { me sinto: Isolado/Integrado }\end{array}$} & Feminino & 20 & 67,20 & 16,82 & 36 & 69,50 & 86 & 0,055 \\
\hline & Masculino & 9 & 80,67 & 4,82 & 72 & 81,00 & 85 & \\
\hline \multirow{2}{*}{$\begin{array}{l}\text { A natureza ensina ao ser } \\
\text { humano como ele deve } \\
\text { viver: Não concordo/Concordo }\end{array}$} & Feminino & 20 & 63,35 & 15,58 & 35 & 64,00 & 86 & 0,436 \\
\hline & Masculino & 9 & 68,00 & 21,28 & 35 & 81,00 & 85 & \\
\hline $\begin{array}{l}\text { Os ambientalistas são pessoas } \\
\text { que deveriam } \\
\text { pensar mais no } \\
\text { desenvolvimento da } \\
\text { sociedade. Não } \\
\text { concordo/Concordo }\end{array}$ & Feminino & 20 & 33,85 & 20,21 & 1 & 37,50 & 80 & $\underline{0,078}$ \\
\hline
\end{tabular}


4D - No grupo Experimento, Pós (continua...):

\begin{tabular}{llrrrrrrr}
\hline $\begin{array}{llrrr}\text { Auto-avaliação } \\
\text { do conhecimento }\end{array}$ & Sexo & $\mathrm{n}$ & Média & $\begin{array}{r}\text { Desvio } \\
\text { Padrão }\end{array}$ & Mín. & Mediana & Máx. & Valor p \\
\hline Mata Atlântica & Feminino & 22 & 68,82 & 16,30 & 42 & 68,50 & 95 & 0,992 \\
& Masculino & 9 & 69,56 & 14,71 & 47 & 67,00 & 95 & \\
\hline Meio Ambiente & Feminino & 22 & 67,50 & 16,76 & 36 & 66,50 & 95 & 0,906 \\
& Masculino & 9 & 67,67 & 23,04 & 33 & 68,00 & 95 & \\
\hline Cavernas de & Feminino & 22 & 58,64 & 24,22 & 2 & 65,50 & 95 & 0,740 \\
Calcário & Masculino & 9 & 57,22 & 21,69 & 28 & 51,00 & 95 & \\
\hline Unidades de & Feminino & 22 & 62,59 & 22,38 & 2 & 66,00 & 95 & 0,615 \\
Conservação & Masculino & 9 & 59,44 & 15,07 & 34 & 58,00 & 80 & \\
\hline Educação & Feminino & 22 & 71,18 & 14,89 & 48 & 68,50 & 97 & 0,556 \\
Ambiental & Masculino & 9 & 72,89 & 20,10 & 33 & 80,00 & 95 & \\
\hline Comunidades & Feminino & 21 & 60,57 & 24,20 & 2 & 67,00 & 95 & 0,167 \\
Tradicionais & Masculino & 9 & 46,89 & 27,11 & 8 & 60,00 & 80 & \\
\hline
\end{tabular}


No grupo Experimento, Pós (continuação 1):

\begin{tabular}{|c|c|c|c|c|c|c|c|c|}
\hline $\begin{array}{l}\text { Atitudes Pró- } \\
\text { Ambiente }\end{array}$ & Sexo & $\mathrm{n}$ & Média & $\begin{array}{l}\text { Desvio } \\
\text { Padrão }\end{array}$ & Mín. & Mediana & Máx. & Valor $p$ \\
\hline \multirow{2}{*}{$\begin{array}{l}\text { Participar do movi- } \\
\text { mento ambientalista }\end{array}$} & Feminino & 22 & 75,14 & 18,82 & 25 & 80,00 & 100 & 0,191 \\
\hline & Masculino & 9 & 82,00 & 22,96 & 32 & 92,00 & 100 & \\
\hline \multirow{2}{*}{$\begin{array}{l}\text { Mudar seus } \\
\text { hábitos de consumo }\end{array}$} & Feminino & 22 & 66,82 & 21,17 & 10 & 69,00 & 100 & 0,513 \\
\hline & Masculino & 9 & 69,44 & 23,61 & 16 & 75,00 & 90 & \\
\hline \multirow{2}{*}{$\begin{array}{l}\text { Visitar áreas } \\
\text { naturais }\end{array}$} & Feminino & 22 & 87,86 & 12,30 & 64 & 94,00 & 100 & 0,139 \\
\hline & Masculino & 9 & 95,33 & 5,68 & 84 & 97,00 & 100 & \\
\hline \multirow[t]{2}{*}{ Usar menos o carro } & Feminino & 22 & 60,55 & 26,41 & 13 & 60,00 & 100 & 0,889 \\
\hline & Masculino & 9 & 60,33 & 26,27 & 20 & 56,00 & 100 & \\
\hline \multirow{2}{*}{$\begin{array}{l}\text { Divulgar a preser- } \\
\text { vação ambiental }\end{array}$} & Feminino & 22 & 76,77 & 20,93 & 15 & 78,00 & 100 & $\underline{0,085}$ \\
\hline & Masculino & 9 & 89,00 & 15,24 & 55 & 92,00 & 100 & \\
\hline \multirow{2}{*}{$\begin{array}{l}\text { Fazer cursos } \\
\text { na área ambiental }\end{array}$} & Feminino & 22 & 76,59 & 21,54 & 15 & 79,00 & 100 & 0,121 \\
\hline & Masculino & 9 & 89,11 & 15,16 & 55 & 94,00 & 100 & \\
\hline \multirow{2}{*}{$\begin{array}{l}\text { Pesquisar e } \\
\text { escrever } \\
\text { artigos de M. Amb. }\end{array}$} & Feminino & 22 & 62,68 & 25,59 & 12 & 60,00 & 100 & 0,214 \\
\hline & Masculino & 9 & 76,78 & 27,16 & 25 & 92,00 & 100 & \\
\hline \multirow{2}{*}{$\begin{array}{l}\text { Rever seus hábitos } \\
\text { economizar recursos }\end{array}$} & Feminino & 22 & 74,05 & 20,65 & 12 & 77,00 & 100 & 0,485 \\
\hline & Masculino & 9 & 80,33 & 18,71 & 45 & 85,00 & 100 & \\
\hline \multirow{2}{*}{$\begin{array}{l}\text { Ler a respeito ou } \\
\text { assistir document. }\end{array}$} & Feminino & 22 & 72,50 & 24,28 & 12 & 76,00 & 100 & 0,599 \\
\hline & Masculino & 9 & 76,56 & 27,02 & 30 & 92,00 & 100 & \\
\hline \multirow{2}{*}{$\begin{array}{l}\text { Ser mais integrado } \\
\text { às outras pessoas }\end{array}$} & Feminino & 22 & 83,00 & 21,86 & 12 & 91,00 & 100 & 0,201 \\
\hline & Masculino & 9 & 88,00 & 21,15 & 35 & 100,00 & 100 & \\
\hline \multirow[t]{2}{*}{ Espiritualizar-se } & Feminino & 22 & 71,36 & 26,47 & 8 & 76,50 & 100 & 0,975 \\
\hline & Masculino & 9 & 71,11 & 29,11 & 25 & 58,00 & 100 & \\
\hline \multirow{2}{*}{$\begin{array}{l}\text { Cuidar de plantas e } \\
\text { animais }\end{array}$} & Feminino & 22 & 81,68 & 16,09 & 52 & 86,00 & 100 & 0,498 \\
\hline & Masculino & 9 & 68,67 & 30,51 & 20 & 68,00 & 100 & \\
\hline \multirow[t]{2}{*}{ Reciclar o lixo } & Feminino & 22 & 83,41 & 15,92 & 56 & 89,00 & 100 & 0,023 \\
\hline & Masculino & 9 & 95,44 & 7,55 & 80 & 100,00 & 100 & \\
\hline \multirow{2}{*}{$\begin{array}{l}\text { Filiar-se à uma } \\
\text { ONG ambientalista }\end{array}$} & Feminino & 22 & 74,59 & 19,35 & 27 & 76,50 & 100 & 0,303 \\
\hline & Masculino & 9 & 81,33 & 25,90 & 30 & 97,00 & 100 & \\
\hline \multirow{2}{*}{$\begin{array}{l}\text { Doar recursos ou } \\
\text { voluntariar-se }\end{array}$} & Feminino & 22 & 76,68 & 20,39 & 14 & 81,00 & 100 & 0,395 \\
\hline & Masculino & 9 & 83,33 & 16,94 & 55 & 88,00 & 100 & \\
\hline \multirow{2}{*}{$\begin{array}{l}\text { Pagar mais } \\
\text { impostos }\end{array}$} & Feminino & 22 & 54,23 & 20,96 & 10 & 57,50 & 84 & 0,170 \\
\hline & Masculino & 9 & 38,44 & 28,07 & 10 & 28,00 & 85 & \\
\hline
\end{tabular}


No grupo Experimento, Pós (continuação 2):

\begin{tabular}{llrrrrrrr}
\hline \multirow{2}{*}{ Sentimentos } & Sexo & $\mathrm{n}$ & Média & $\begin{array}{r}\text { Desvio } \\
\text { Padrão }\end{array}$ & Mín. & Mediana & Máx. & Valor $p$ \\
\hline Alerta/sonolento & Feminino & 22 & 70,77 & 21,20 & 18 & 73,00 & 98 & 0,677 \\
& Masculino & 9 & 56,89 & 39,40 & 3 & 71,00 & 96 & \\
\hline calmo/agitado & Feminino & 22 & 50,64 & 27,07 & 4 & 52,00 & 98 & 0,661 \\
& Masculino & 9 & 52,67 & 25,04 & 15 & 50,00 & 95 & \\
\hline com idéias & Feminino & 22 & 45,77 & 27,49 & 2 & 47,50 & 98 & 0,724 \\
claras/confuso & Masculino & 9 & 41,78 & 37,06 & 4 & 28,00 & 95 & \\
\hline satisfeito/ & Feminino & 22 & 74,18 & 16,14 & 47 & 79,50 & 98 & 0,991 \\
insatisfeito & Masculino & 9 & 67,89 & 33,75 & 6 & 77,00 & 96 & \\
\hline tranqüilo/ & Feminino & 22 & 52,36 & 29,79 & 3 & 51,00 & 98 & 0,062 \\
preocupado & Masculino & 9 & 33,00 & 24,16 & 2 & 31,00 & 78 & \\
\hline atento/distraído & Feminino & 22 & 41,09 & 22,63 & 3 & 45,00 & 88 & 0,328 \\
& Masculino & 9 & 30,89 & 22,78 & 2 & 22,00 & 71 & \\
\hline alegre/triste & Feminino & 22 & 33,50 & 25,47 & 3 & 31,50 & 91 & 0,339 \\
& Masculino & 9 & 27,44 & 29,91 & 2 & 21,00 & 94 & \\
\hline interessado/ & Feminino & 22 & 56,82 & 21,01 & 13 & 50,00 & 96 & 0,421 \\
desinteressado & Masculino & 9 & 47,67 & 39,08 & 2 & 37,00 & 95 & \\
\hline seguro/inseguro & Feminino & 22 & 58,36 & 22,93 & 6 & 60,00 & 96 & 0,614 \\
& Masculino & 9 & 52,33 & 28,39 & 3 & 50,00 & 96 & \\
\hline solitário/ & Feminino & 22 & 52,27 & 20,95 & 15 & 50,00 & 98 & 0,138 \\
integrado & Masculino & 9 & 37,00 & 34,59 & 3 & 22,00 & 95 & \\
\hline confiante/ & Feminino & 22 & 42,18 & 19,34 & 3 & 43,50 & 90 & 0,339 \\
temeroso & Masculino & 9 & 36,22 & 27,54 & 3 & 36,00 & 81 & \\
\hline
\end{tabular}


No grupo Experimento, Pós (continuação 3):

\begin{tabular}{|c|c|c|c|c|c|c|c|c|}
\hline Valores & Sexo & $\mathrm{n}$ & Média & $\begin{array}{l}\text { Desvio } \\
\text { Padrão }\end{array}$ & Mín. & Mediana & Máx. & Valor $p$ \\
\hline \multirow{2}{*}{$\begin{array}{l}\text { O que você acha da relação } \\
\text { dos animais } \\
\text { da mata com o homem? } \\
\text { Ruins/bons }\end{array}$} & Feminino & 22 & 49,27 & 27,06 & 10 & 48,50 & 99 & 0,156 \\
\hline & Masculino & 9 & 33,11 & 16,65 & 13 & 27,00 & 59 & \\
\hline \multirow{2}{*}{$\begin{array}{l}\text { O que você sente quando } \\
\text { ouve falar sobre a } \\
\text { extinção de plantas e } \\
\text { animais? Não posso fazer } \\
\text { nada/Posso fazer muito }\end{array}$} & Feminino & 22 & 63,95 & 25,79 & 14 & 67,50 & 100 & 0,232 \\
\hline & Masculino & 9 & 74,89 & 23,65 & 28 & 78,00 & 100 & \\
\hline \multirow{2}{*}{$\begin{array}{l}\text { Ao entrar em uma mata } \\
\text { você fica: } \\
\text { Com medo/Muito animado }\end{array}$} & Feminino & 22 & 84,00 & 14,80 & 57 & 87,50 & 100 & 0,115 \\
\hline & Masculino & 9 & 92,44 & 9,08 & 81 & 100,00 & 100 & \\
\hline $\begin{array}{l}\text { O que você sente sobre a } \\
\text { caça e a venda de } \\
\text { animais silvestres? }\end{array}$ & Feminino & 22 & 92,73 & 13,15 & 56 & 99,00 & 100 & 0,427 \\
\hline $\begin{array}{l}\text { Concordo totalmente/ } \\
\text { Discordo totalmente }\end{array}$ & Masculino & 9 & 91,11 & 20,68 & 38 & 100,00 & 100 & \\
\hline \multirow{2}{*}{$\begin{array}{l}\text { O que você sente quando } \\
\text { vê áreas de mata } \\
\text { queimando? Feliz/Triste }\end{array}$} & Feminino & 22 & 90,36 & 13,69 & 56 & 97,00 & 100 & 0,246 \\
\hline & Masculino & 9 & 89,00 & 21,37 & 44 & 100,00 & 100 & \\
\hline \multirow{2}{*}{$\begin{array}{l}\text { Garantir a preservação de } \\
\text { uma espécie é garantir a } \\
\text { preservação da mata. } \\
\text { Concordo/Discordo }\end{array}$} & Feminino & 22 & 75,59 & 30,42 & 10 & 90,50 & 100 & 0,355 \\
\hline & Masculino & 9 & 84,22 & 27,10 & 16 & 97,00 & 100 & \\
\hline \multirow{2}{*}{$\begin{array}{l}\text { Ao entra numa caverna de } \\
\text { calcário você fica: } \\
\text { Com medo/Muito animado }\end{array}$} & Feminino & 22 & 83,59 & 18,60 & 32 & 92,00 & 100 & 0,263 \\
\hline & Masculino & 9 & 86,67 & 22,86 & 36 & 95,00 & 100 & \\
\hline \multirow{2}{*}{$\begin{array}{l}\text { O modo de vida das } \\
\text { populações tradicionais } \\
\text { deve ser mantido. Não } \\
\text { Concordo/Concordo }\end{array}$} & Feminino & 22 & 91,36 & 9,67 & 60 & 94,50 & 100 & 0,189 \\
\hline & Masculino & 9 & 85,33 & 29,24 & 18 & 100,00 & 100 & \\
\hline \multirow{2}{*}{$\begin{array}{l}\text { Visitar áreas naturais é: } \\
\text { Incômodo/Agadável }\end{array}$} & Feminino & 22 & 92,27 & 9,78 & 57 & 93,00 & 100 & 0,008 \\
\hline & Masculino & 9 & 99,22 & 1,72 & 95 & 100,00 & 100 & \\
\hline \multirow{2}{*}{$\begin{array}{l}\text { A preservação da Mata } \\
\text { Atlântica: } \\
\text { É urgente/ Não é urgente }\end{array}$} & Feminino & 22 & 92,91 & 8,09 & 70 & 94,50 & 100 & 0,041 \\
\hline & Masculino & 9 & 99,33 & 1,12 & 97 & 100,00 & 100 & \\
\hline \multirow{2}{*}{$\begin{array}{l}\text { Quando estou em contato } \\
\text { direto com a Natureza eu } \\
\text { me sinto: Isolado/Integrado }\end{array}$} & Feminino & 22 & 88,18 & 15,83 & 55 & 94,50 & 100 & $\underline{0,050}$ \\
\hline & Masculino & 9 & 94,44 & 14,88 & 55 & 100,00 & 100 & \\
\hline \multirow{2}{*}{$\begin{array}{l}\text { A natureza ensina ao ser } \\
\text { humano como ele deve } \\
\text { viver: Não } \\
\text { concordo/Concordo }\end{array}$} & Feminino & 22 & 86,27 & 16,02 & 55 & 93,00 & 100 & 0,854 \\
\hline & Masculino & 9 & 81,67 & 20,13 & 55 & 85,00 & 100 & \\
\hline $\begin{array}{l}\text { Os ambientalistas são } \\
\text { pessoas que deveriam } \\
\text { pensar mais no } \\
\text { desenvolvimento da } \\
\text { sociedade. Não } \\
\text { concordo/Concordo }\end{array}$ & Masculino & 22 & 52,45 & 21,95 & 10 & 59,50 & 100 & 0,600 \\
\hline
\end{tabular}




\section{ANEXO 5 - PLANILHA COM DADOS ORIGINAIS NÃO TRATADOS} ESTUDOS 3a E 3b (EM VERSÃO MICROSOFT - EXCEL) 